\title{
Polidopamin alkalmazása a szerves kémiában: \\ katalizátor hordozótól a fotoizomerizálható felületekig
}

\author{
Ph.D. értekezés
}

\section{Kunfi Attila}

Témavezetö:

Dr. London Gábor
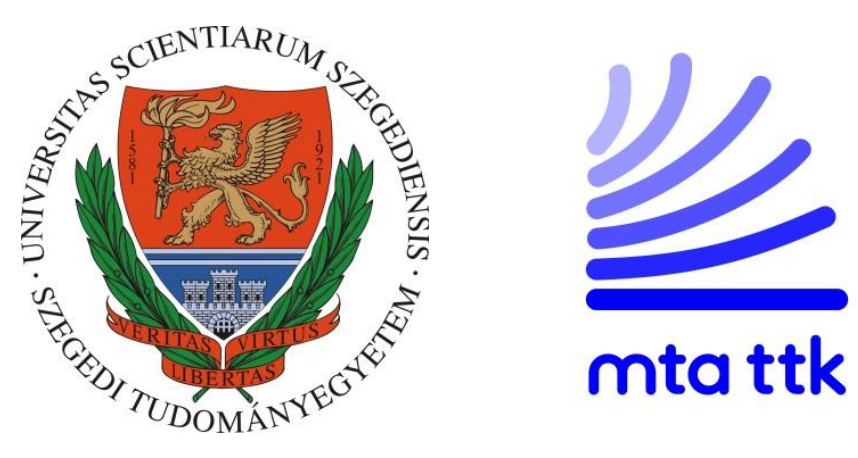

Magyar Tudományos Akadémia Természettudományi Kutatóközpont

Szerves Kémiai Intézet

Budapest

Szegedi Tudományegyetem Természettudományi és Informatikai Kar Szerves Kémiai Tanszék

Kémia Doktori Iskola

Szeged 


\section{Tartalomjegyzék}

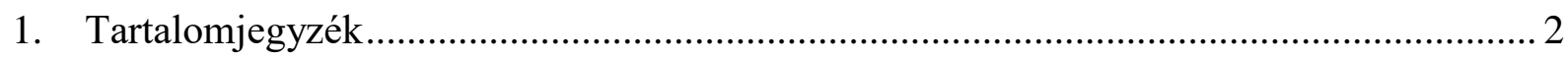

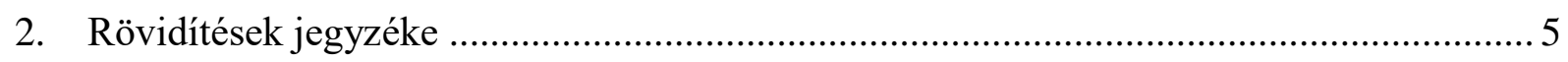

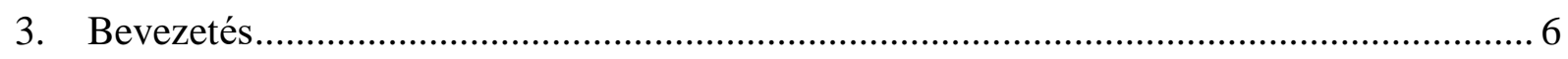

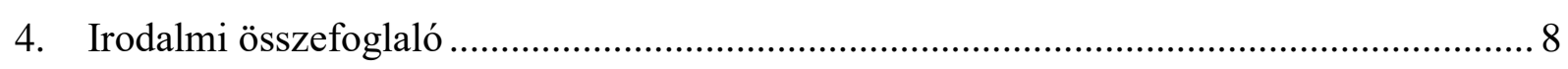

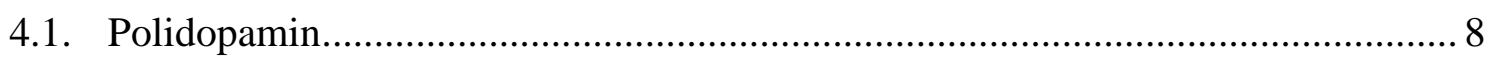

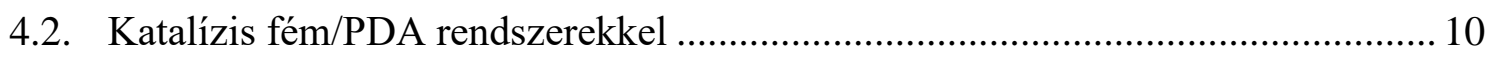

4.2.1. Katalitikus transzfer hidrogénezés .................................................... 11

4.2.2. C-C kapcsolási reakciók ................................................................... 12

4.2.3. Tandem Suzuki reakció/nitroredukció ................................................. 15

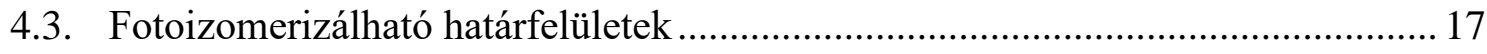

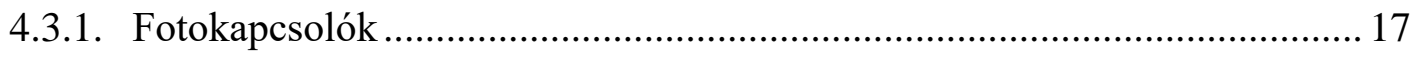

4.3.2. Fotoizomerizáció szilárd határfelületeken ........................................... 19

4.3.3. Ligandumcsere szilárd határfelületeken ............................................ 21

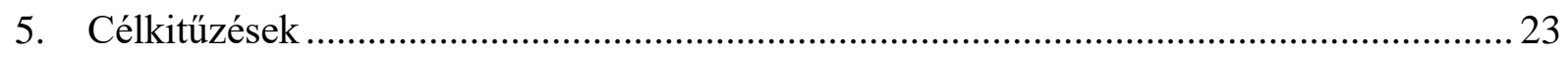

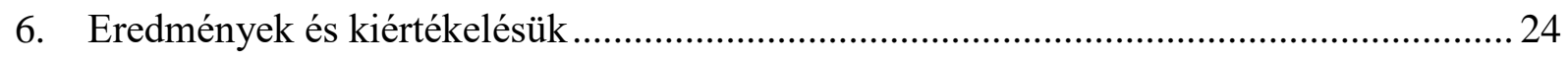

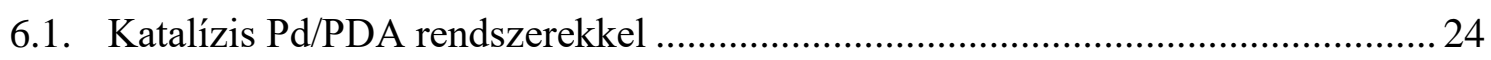

6.1.1. Pd nanorészecskék létrehozása PDA felületen ........................................ 24

6.1.2. Katalitikus transzfer hidrogénezés ….................................................. 27

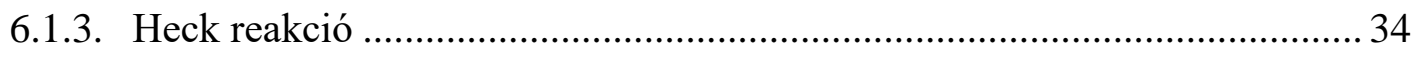

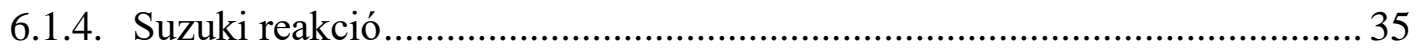

6.1.5. Tandem Suzuki reakció/katalitikus transzfer hidrogénezés......................... 42

6.2. Fotoizomerizálható határfelületek előállítása PDA hordozón.............................. 48

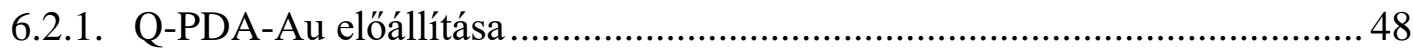

6.2.2. Azobenzol származékok szintézise ................................................... 49 
6.2.3. Q-PDA-Au felület módosítása azobenzol származékokkal

6.2.4. Azobenzol származékok izomerizációja a módosított felületeken .............. 55

6.2.5. Ligandumcsere Q-PDA-Au felületen ................................................... 57

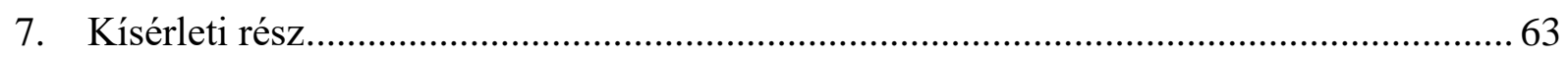

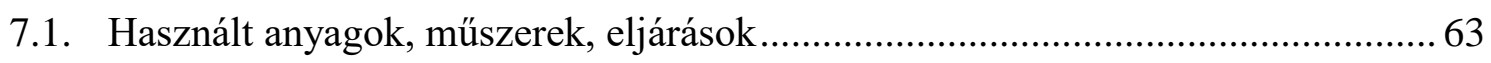

7.2. Dopamin tömb-, és filmpolimerizációja, PDA módosítása Pd nanorészecskékkel .. 64

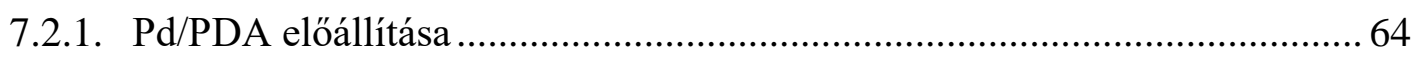

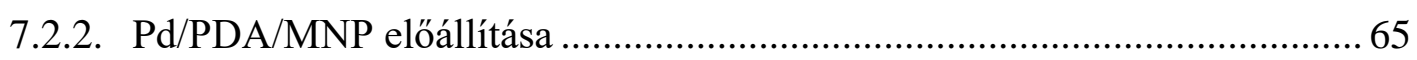

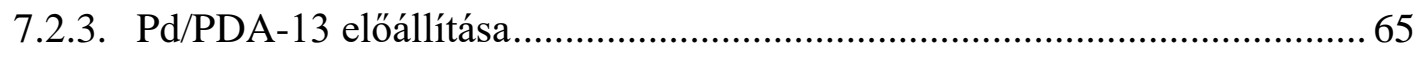

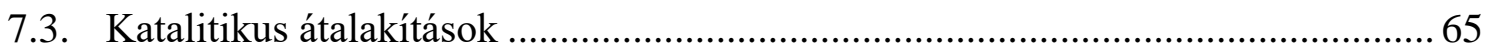

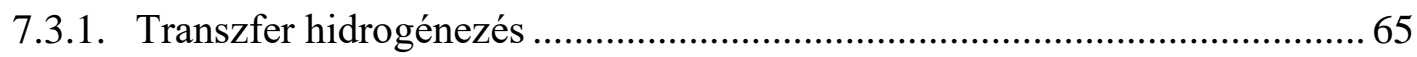

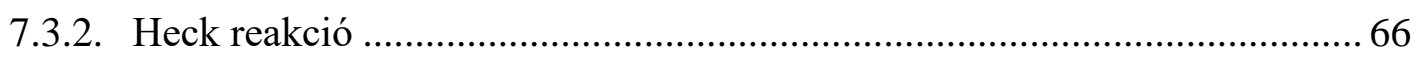

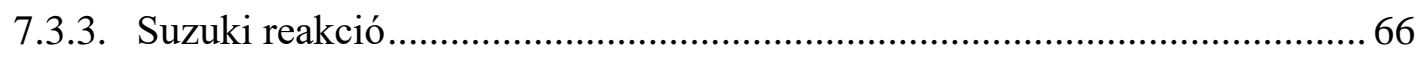

7.3.4. Tandem Suzuki reakció/transzfer hidrogénezés .....................................66

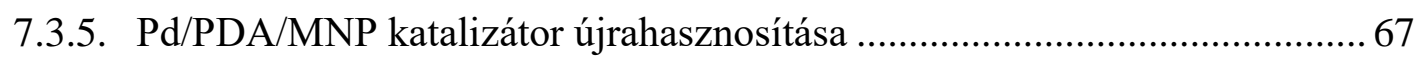

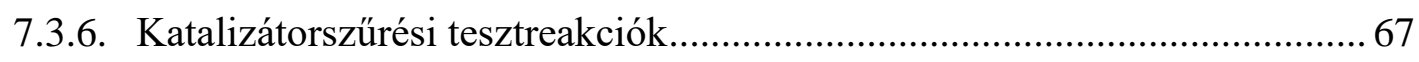

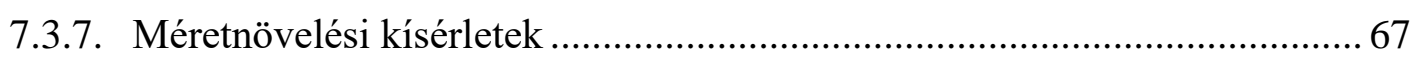

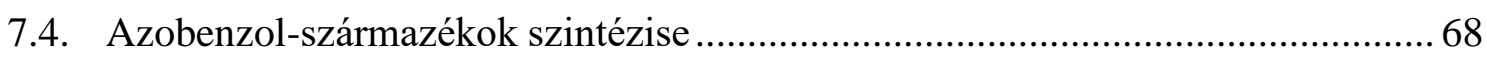

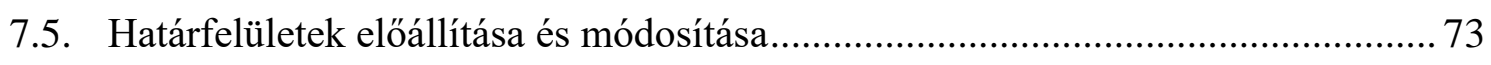

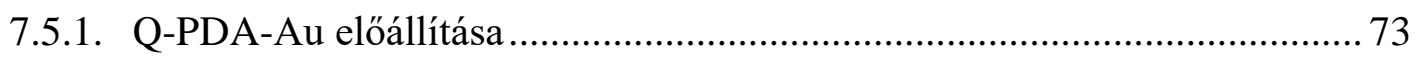

7.5.2. Q-PDA-Au módosítása azobenzol származékokkal ................................. 73

7.5.3. Ligandumcsere Q-PDA-Au felületen ..................................................... 73

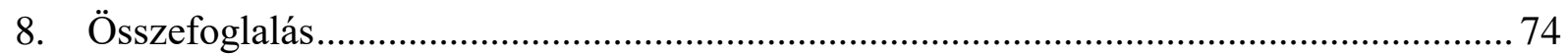

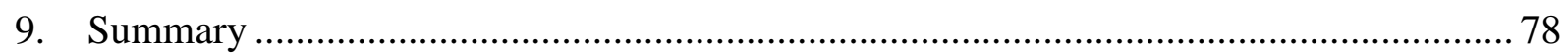

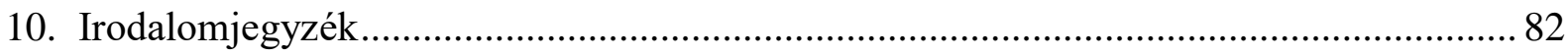

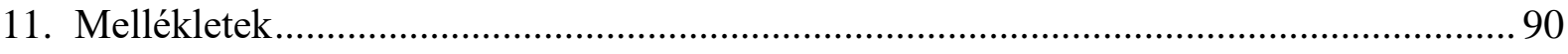


11.1. Katalitikus átalakítások során nyert termékek NMR jellemzése..........................90

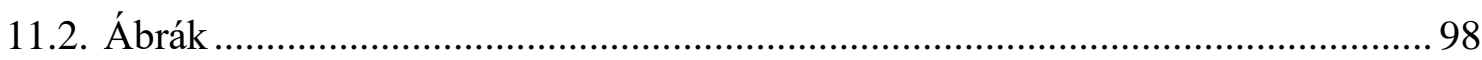

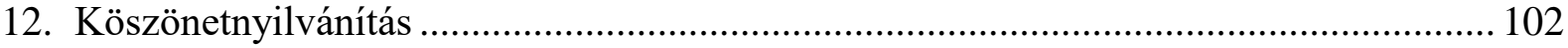




\section{Rövidítések jegyzéke}

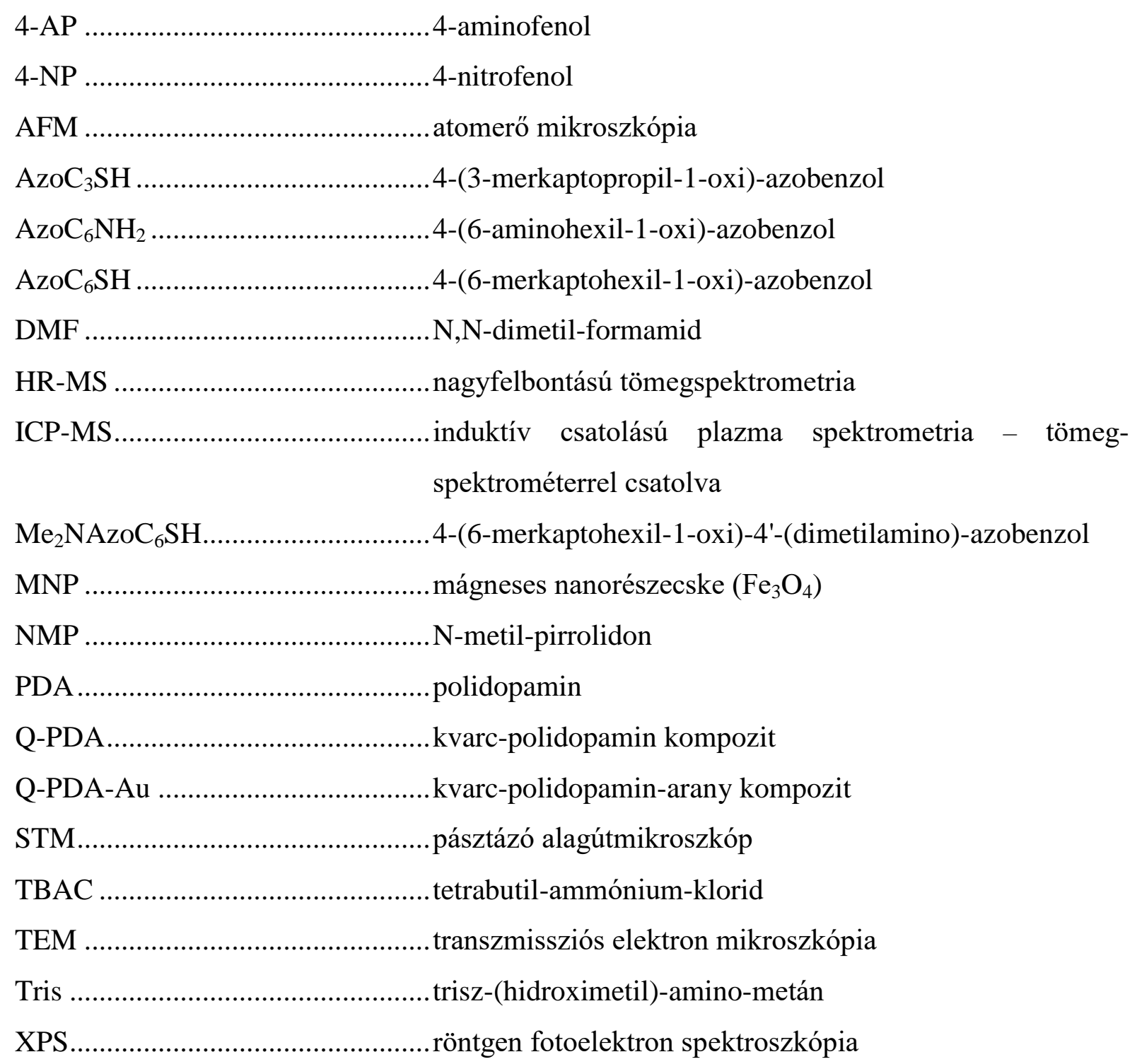




\section{Bevezetés}

Határfelületnek nevezzük azt a térrészt, ami elválaszt egy anyaghalmazt környezetétől. Mivel a határfelületeken elhelyezkedő atomok, valamint molekulák eltérő kémiai környezetben vannak a tömbfázisban lévőkhöz képest, ezért kémiai tulajdonságaik is eltérőek, reaktívabbak, így hatékonyabban vehetnek részt különböző kémiai vagy biológiai folyamatokban.

Ilyen, kitüntetett helyzetü határfelületi atomok/molekulák növelhetik egy kémiai reakció sebességét anélkül, hogy a reakció során elfogynának. Ezt a folyamatot heterogén katalízisnek nevezzük, melyben a szilárd katalizátor felületén találhatóak a katalitikusan aktív centrumok. Ezeken a centrumokon reakció során reaktánsok adszorbeálódnak a környezetböl, felületi diffúzióban vesznek részt, mely során közel kerülnek reakciópartnereikhez, amikkel elreagálva új molekulákat képeznek. Végül a keletkezett termékek deszorbeálódnak a felületről, helyükre pedig újabb reaktánsok kötődhetnek. Amennyiben egy folyamatban több termék keletkezhet, de a katalizátorunkkal egy specifikus termék keletkezését tudjuk előidézni, úgy szelektív katalízisről beszélünk. Minél nagyobb a termékképződés sebessége a katalizátor jelenlétében, annál reaktívabb felületi atomokat tartalmaz a határfelület. Előfordulhat, hogy nem csak a reaktáns termékké alakulása, de ezzel párhuzamosan a katalitikusan aktív atom felületről való leszakadása is megtörténik, ami a katalizátor aktivitásának csökkenéséhez, vagy akár teljes dezaktiválódásához is vezethet. Ha azonban az ilyen aktivitásvesztés kiküszöbölhető, és a szilárd katalizátor könnyen eltávolítható a reakcióelegyből, akkor akár többször is újrahasznosítható lehet a katalizátorunk kémiai átalakításokban. Napjaink vegyiparában nélkülözhetetlenek a katalitikus átalakítások. Mind a nehézvegyiparban (ammónia szintézis, kőolaj feldolgozás), mind a gyógyszer- illetve finomvegyszer gyártásban cél a legtartósabb, legaktívabb, legolcsóbb módszer és katalizátor alkalmazása. Mindemellett, élhető környezetünk megóvása érdekében nélkülözhetetlenné vált a „zöld kémia” alapelveit kielégítő eljárások kidolgozása és alkalmazása. Ezért, a határfelületen lejátszódó folyamatok megértése, és befolyásolása fontos céllá vált a 21 . század kutatói számára, amihez folyamatosan fejlődő, és egyre kifinomultabb nagymüszeres technikák is segítséget nyújtanak.

A határfelületi jelenségek tanulmányozása a heterogén katalízisen túl egyre több más kémiai vagy kémiával határos területen is megjelenik. Jelentős technológiai kihívást jelent például kémiai, valamint fizikai energiát nagy hatásfokkal tárolni, vagy átalakítani. 
Amennyiben tovább szeretnénk csökkenteni elektronikai eszközeink méretét, miközben növeljük müveleti és tároló kapacitásukat, létre kell hoznunk molekuláris méretü tranzisztorokat, és egyéb elektronikai alkatelemeket. Ugyanez igaz az analitikai berendezésekre is. A megfelelő molekulák segítségével nanoanalitikai bioszenzorokat hozhatunk létre a jövőben, amelyek már nem csak egy emberi kézben férhetnek el, de akár emberi szervezetbe is bejuttathatók.

Ha határfelületen szeretnénk folyamatokat irányítani, akkor egy olyan ingerre van szükségünk, ami könnyen elérhető, vagy előállítható, a felület adott pontjára koncentrálható, és nem tesz kárt a határfelületben. Ilyen, külső inger a fény, amelynek a különböző hullámhosszaival akár több, eltérő fizikai és kémiai tulajdonságú rendszert is irányíthatunk egy időben. Ehhez azonban létre kell hoznunk azokat a rendszereket, amik gyorsan, nagy hatásfokkal, valamilyen tulajdonságuk radikális megváltoztatásával reagálnak fénybesugárzásra.

A fentebb felvázolt területek felderítéséhez alapkutatásra van szükségünk, ami egy hosszútávú befektetés. Segítségével megérthetjük a körülöttünk létező világ jelenségeit, majd a megszerzett tudást felhasználva, a jövőben lemásolhatjuk, kihasználhatjuk, vagy befolyásolhatjuk a természetben lejátszódó folyamatokat, újat alkothatunk.
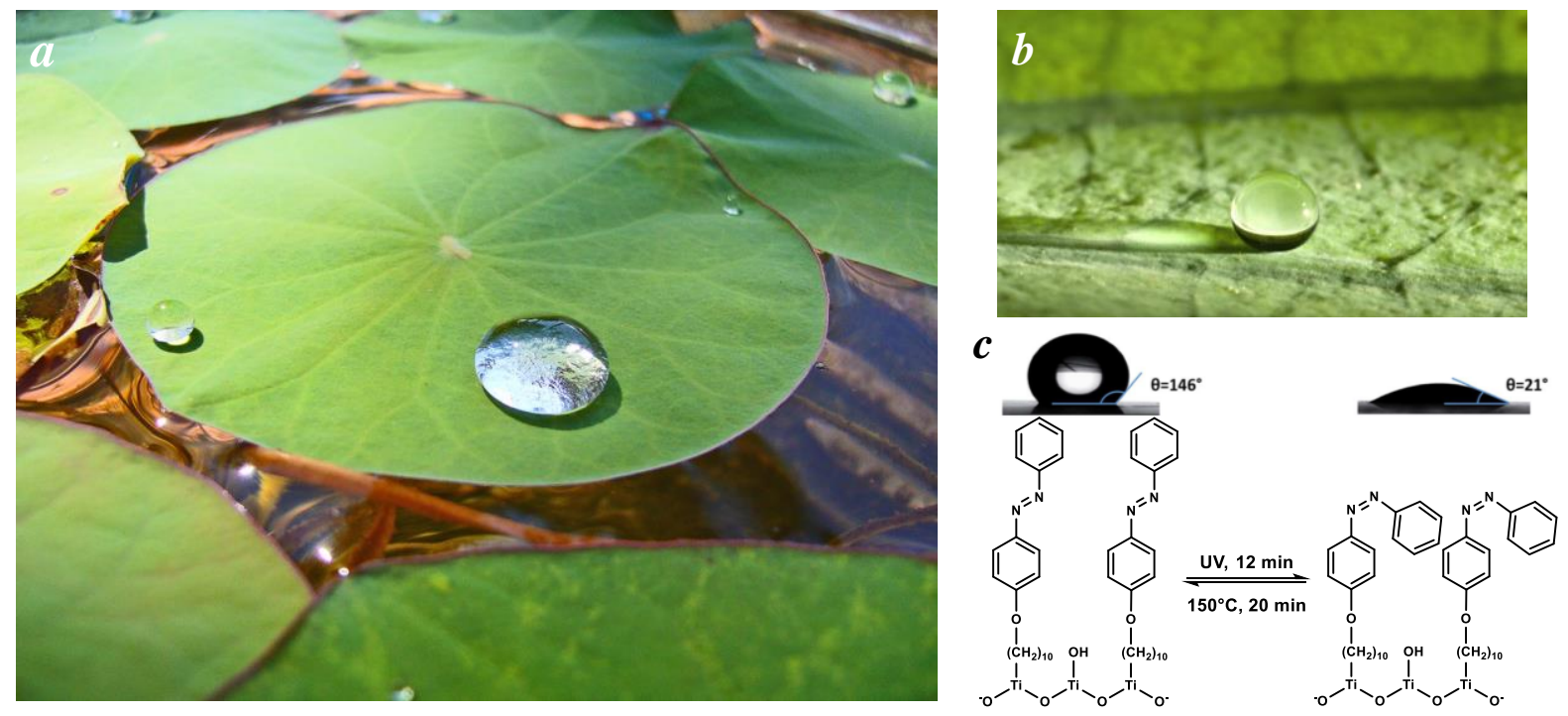

1. ábra $(a, b)$ Vízcseppek lótuszleveleken. A mikroszkopikus méretű (50 - $100 \mathrm{~nm})$, hidrofób tüskékkel borított levélfelületnek köszönhetően nagy kontaktszöggel $\left(>160^{\circ}\right)$ ülnek rajta a vízcseppek. (c) Azobenzol származékokkal módosított $\mathrm{TiO}_{2}$ nanorészecskékkel borított felület. Hasonlóan egyenetlen és hidrofób, mint a lótuszlevél, azonban nedvesedő képessége fénybesugárzással megváltoztatható. ${ }^{[1]}$ 


\section{Irodalmi összefoglaló}

\subsection{Polidopamin}

A természetben előforduló jelenségek megfigyelése és megértése új lehetőségeket teremt a tudományos fejlődés számára. Egy ilyen érdekfeszítő jelenség, ami iránt a biokémia és a szerves anyagtudományok területén folyamatosan növekvő érdeklődés mutatkozik, a mikro-, és makroorganizmusok által előállított bioadhezívek vizsgálata. A laposférgek másodpercek alatt képesek megtapadni nedves sziklákon vagy elszabadulni róluk; a tengeri uborkák azonnal megkötő ragasztóanyag kilövellésével zavarják meg ragadozóikat; egyes rovarok a levelek fonákjára ragasztják petéiket; pókok és bársonyférgek ragadós fonalaikkal kapják el zsákmányaikat; a tengeri és folyami kagylók pedig megtapadnak a legváltozatosabb anyagi minőségü felületeken is. A kagylók ragasztóanyagának vizsgálatáról már 1981-ben megjelent egy publikáció, melyben a szerzők izolálták és analizálták az élőlények által kiválasztott fehérjéket, és nagy mennyiségü lizin, dopa, valamint hidroxiprolin jelenlétét mutatták ki bennük. ${ }^{[2]}$ Ezeknek az aminosavaknak a hidoxil-, és aminocsoportjai által létesített hidrogénkötéseket tették felelőssé az erős felületi adhézióért (2. ábra). Csak több mint két évtizeddel később, Messersmith és kutatócsoportja világított rá, hogy dopa, ${ }^{[3]}$ valamint dopamin $^{[4]}$ oxidatív autopolimerizációja során hasonló szerkezetủ és tulajdonságú polimert nyerhetünk. Ezzel a felfedezéssel megindult a polidopamin fizikai és kémiai tulajdonságainak, valamint alkalmazhatóságának a kutatása, ami az elmúlt évtized során exponenciális mértékben növekvő számú publikáció megjelenését eredményezte. ${ }^{[5,6,7,8]}$
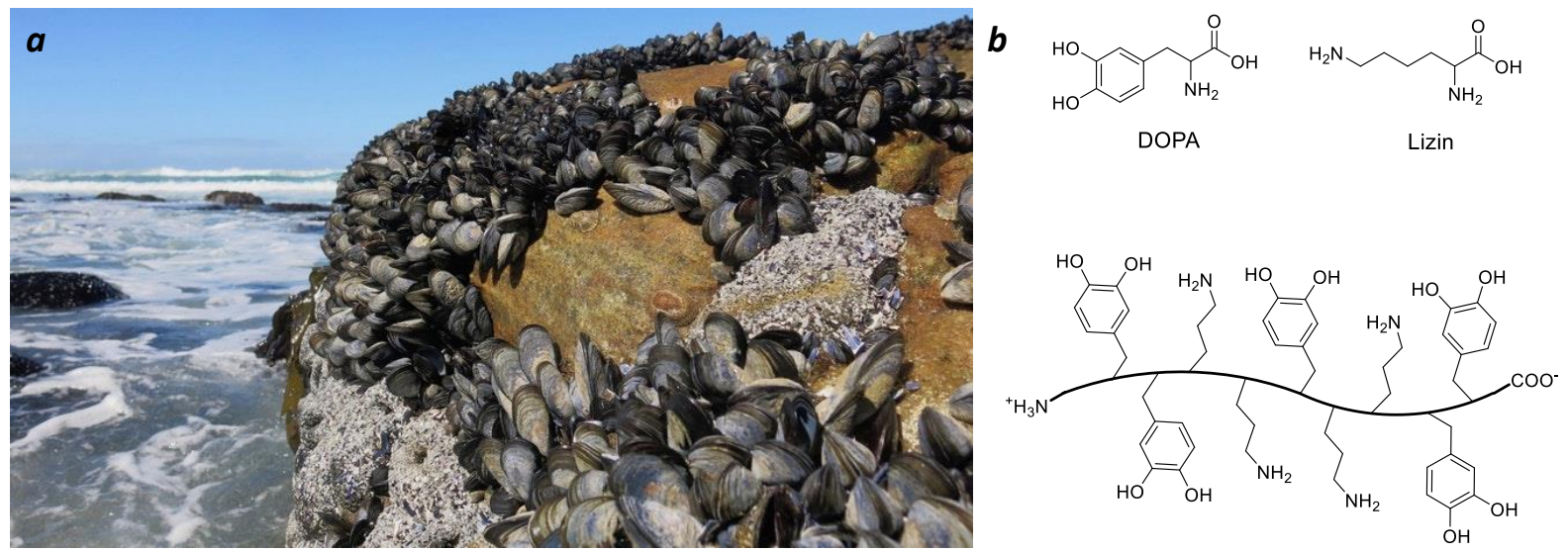

2. ábra (a) Sziklára tapadt kagylók apály idején. (b) DOPA és lizin szerkezeti képlete, valamint a kagylók által kiválasztott fehérje egy peptidrészletének sematikus ábrázolása. 
Polidopamint (PDA-t) elöállíthatunk dopamin-hidroklorid bázikus $\mathrm{pH}-\mathrm{ra}(\mathrm{pH} \approx 8,5)$ pufferelt vizes oldatából aerob körülmények között (3. ábra). ${ }^{[4]}$ Pufferként legtöbbször trisz(hidroximetil)-amino-metánt (Tris) és hidroklorid sóját használják, ${ }^{[9]}$ de Tris-en kívül használatos még foszfát-puffer, ammónia, nátrium-hidrogén-karbonát is. Piperidin bázisként való alkalmazása lehetővé teszi a polimerizáció végbemenetelét szerves oldószerben, így vízérzékeny anyagok is bevonhatók PDA-val. ${ }^{[10]}$ A polimerizáció oxidatív körülmények között megy végbe, ezért szükséges a levegőben lévő oxigén beoldódása a reakcióelegybe. Ezen kívül, a folyamat lejátszódik egyéb oxidálószerek jelenlétében is $\left(\mathrm{KMnO}_{4}, \mathrm{H}_{2} \mathrm{O}_{2}\right.$, $\mathrm{NH}_{4} \mathrm{~S}_{2} \mathrm{O}_{8}, \mathrm{Fe}_{2}\left(\mathrm{SO}_{4}\right)_{3}, \mathrm{Fe}(\mathrm{II}) / \mathrm{H}_{2} \mathrm{O}_{2}, \mathrm{Cu}(\mathrm{II}), \mathrm{UV}$-fény/O $\left.\mathrm{O}_{2}\right),{ }^{[1-14]}$ azonban ekkor a polimerizáció jelentősen gyorsabb $(10-60$ perc $)$, mint oxigént használva $(1-24$ óra). A polimerizáció pontos mechanizmusa nem ismert, viszont a PDA képződése közben detektálható köztitermékek arra engednek következtetni, ${ }^{[15,16]}$ hogy a dopamin részleges oxidációja során dopamin-kinon keletkezik, aminek primer aminja intramolekulárisan gyürüt zárhat a kinonhoz képest $\beta$ helyzetü szénnel (3. ábra). Az így keletkező indolin-kinon és a dopamin-kinon tautomer formái egymással C-C kötéseket létesíthetnek különböző helyzetekben.
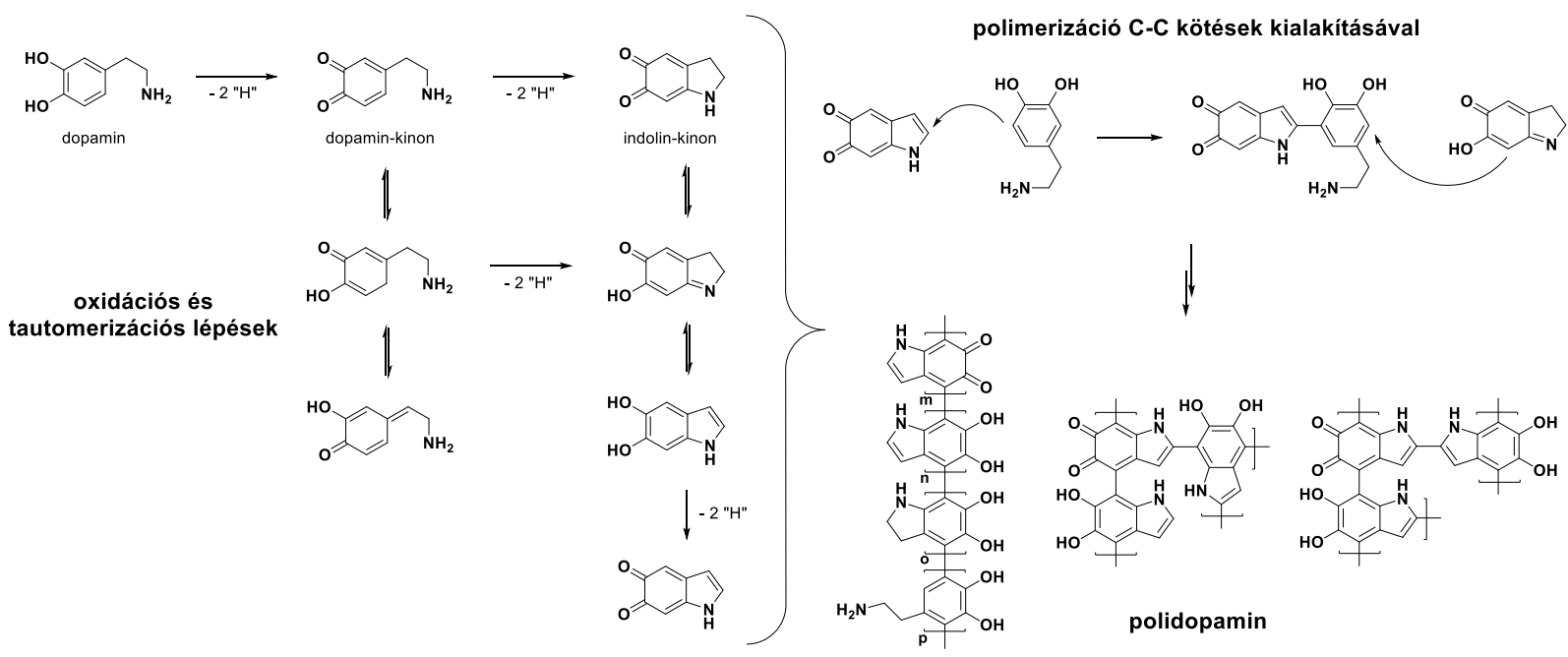

3. ábra Dopamin oxidatív polimerizációjának feltételezett mechanizmusa. ${ }^{[8]}$

Több oldalról is bizonyítást nyert, hogy a PDA nem egy egységes polimer, hanem oligomer láncok és hálózatok együttese. Nagymüszeres vizsgálatok alapján (HR-MS, NMR, XPS, IR) legnagyobb mértékben a 3. ábrán feltüntetett oligomer egységeket találták a PDA építőelemei között. ${ }^{[17]}$ PDA-val módosított AFM tü segítségével vizsgálták a tűn elhelyezkedő molekulák és a felület közt ébredő kölcsönhatások erősségét. ${ }^{[18]}$ Az eredményekből arra következtettek, hogy a PDA kovalnes kötések által összekapcsolt egységeket tartalmazó, 
átlagosan $200 \mathrm{~nm}$ hosszúságú polimerszálakból épül fel, a szálak pedig nagyrészt gyenge, de néhány pontban erös másodlagos kölcsönhatásokat alakítottak ki a vizsgált felülettel $\left(\mathrm{TiO}_{2}\right)$. Polimerizáció közben a keletkező PDA gyakorlatilag bármilyen kémiai minőségü felületen képes megtapadni, ami a funkciós csoportokban gazdag polimerláncok közötti, és a polimerszubsztrátfelület között ébredő hidrogénkötéseknek, és aromás $\pi-\pi$ kölcsönhatásoknak köszönhető. ${ }^{[4]}$

A bázis, az oxidálószer, az oldószer, a kezdeti dopamin koncentráció és a reakcióidő változtatásával a keletkező PDA tulajdonságai nagymértékben befolyásolhatók. Tömbpolimerizáció esetén a PDA nanorészecskék átmérője, filmpolimerizáció esetén a polimer rétegvastagsága jelentősen függ az alkalmazott körülményektől. A polimerizáció körülményeitől függetlenül a keletkező PDA több-kevesebb katekol típusú hidroxilcsoportot tartalmaz, amelyek redox-aktívak (katekol/orto-kinon $E^{\circ}=0,34 \mathrm{~V}$ ), így a PDA képes a $\mathrm{Cu}(\mathrm{II}) / \mathrm{Cu}(0)$ és az annál pozitívabb standard elektródpotenciálú fém/fémion rendszer redukciójára, tehát a megfelelő fémsó oldatából elemi fém előállítására (4. ábra). ${ }^{[12]}$ Redukció után a fématomok nanorészecskékké összeállva stabilizálódnak a PDA felületén a polimer különböző O és N tartalmú funkciós csoportjaihoz koordinálva. Így apró méretű $(<100 \mathrm{~nm})$, nagy diszperzitású és stabilitású fém nanorészecskéket kapunk.

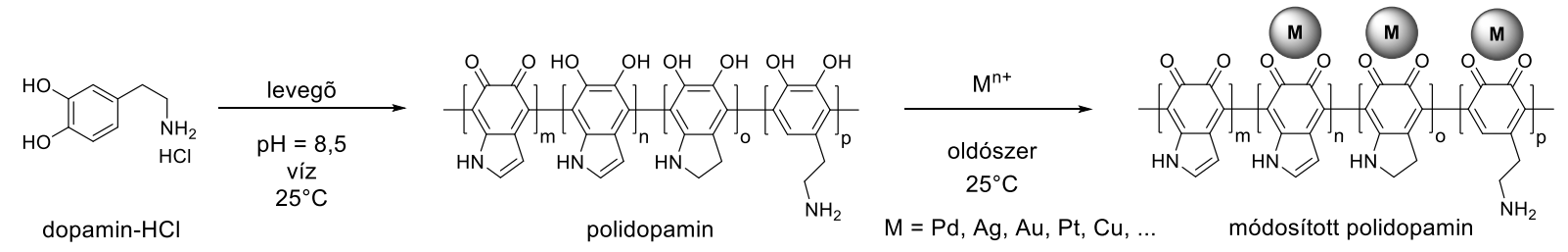

4. ábra Fém nanorészecskék létrehozása PDA felületen.

\subsection{Katalízis fém/PDA rendszerekkel}

Napjainkban egyre inkább előtérbe kerül a könnyen előállítható és stabil heterogén katalizátorok iránti igény, a homogén fémkoplexekhez képest egyszerübb kezelhetőségüknek, a termékelegytől történő könnyebb elválaszthatóságuknak, és újrahasznosíthatóságuknak köszönhetően. Habár találhatunk példát fémmentes PDA által katalizált reakcióra is, ${ }^{[19]}$ kihasználva a PDA redox-aktivitását és univerzális adhezív képességét, a katalitikus szerves kémia számára fontos, átmenetifém nanorészecskéket tartalmazó katalizátorokat hozhatunk létre különböző felületeken. ${ }^{[20,21]}$ A fém/PDA/hordozó összetételű rendszerek előállítása 
kielégíti a zöld kémia több követelményét: a PDA nem toxikus ${ }^{[22]}$; bármilyen felületet bevonhatunk a polimerrel vizes közeget használva; minimális mennyiségü hulladék keletkezik a polimerizáció közben; elemi állapotú fém leválasztása a PDA-ra hozzáadott redukálószer nélkül is végbemegy; a polimerizáció és a fémredukció is szobahőmérsékleten lejátszódik. A megfelelő fém, szubsztrát, és reakciókörülmények megválasztásával aktív, újrahasznosítható katalizátort nyerhetünk.

\subsubsection{Katalitikus transzfer hidrogénezés}

A szakirodalomban számtalan heterogén átmenetifém katalizátorra találhatunk példát, melyeknek alkalmazhatóságát csupán néhány igen népszerủ modellreakcióval demonstrálták. Egy ilyen elterjedt modellreakció a nitrobenzol és származékainak katalitikus transzfer hidrogénezése, legtöbbször 4-nitrofenolnak (4-NP) a redukciója 4-aminofenollá (4-AP). ${ }^{[23]} \mathrm{A}$ reakció $\mathrm{NaBH}_{4}$ redukálószer jelenlétében, szobahőmérsékleten, vizes közegben végbemegy. Környezetkémiai relevanciáját az ipari növényvédőszer és festékanyaggyártásban keletkező, toxikus 4-NP kevésbé káros 4-AP-vá alakítása adja. A fém/PDA rendszerek által katalizált transzfer hidrogénezések irodalmában $\mathrm{Au}^{[24-34]}, \mathrm{Ag}^{[35-41]}, \mathrm{Pd}^{[34,42-45]}$, és $\mathrm{Pt}^{[46]}$ tartalmú, valamint multikomponensű (pl. Au+Ag) ${ }^{[47-49]}$ fém/PDA/hordozó katalizátorokat találunk (5. ábra).

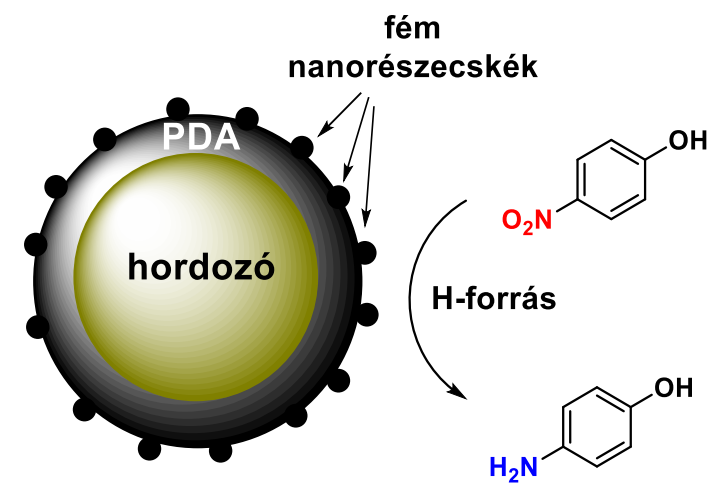

5. ábra Fém/PDA/hordozó rendszerrel katalizált 4-nitrofenol redukció.

Egy heterogén katalizátor aktivitását leginkább befolyásoló tényezők a fém nanorészecskék mérete és geometriája, valamint a hordozóval való interakciójuk. Zhang és munkatársai 4-NP-t redukáltak mezopórusos szilika hordozón rögzített $\mathrm{Pd}, \mathrm{Pt}, \mathrm{Ag}$, és $\mathrm{Au}$ katalizátor segítségével. ${ }^{[50]}$ A kezdeti reakciósebesség jelentős növekedését figyelték meg, amennyiben PDA-t használtak a fém nanorészecskék hordozóhoz rögzítéséhez. Elméleti kémiai számításokkal igazolták, hogy a PDA megváltoztatja a reaktáns koordinációja során a felületén elhelyezkedő fém nanorészecskéken ébredő töltéseloszlást, ami a 4-NP fém 
nanorészecskékhez történő erősebb koordinációját eredményezi, csökkentve ezzel a reakció aktiválási energiáját. A hordozó kémiai minőségétől azonban nem látszik jelentősen függeni a fém/PDA rendszer katalitikus aktivitása. Több, különböző hordozón is (pl. grafén, $\left.{ }^{[26,} 38,42,49\right]$ makropórusos rendszerek, ${ }^{[27,36,37,43]}$ mezopórusos szilikák, ${ }^{[40,45]}$ polimerek, ${ }^{[31,48]}$ pórusos membrán ${ }^{[34]}$ ) ugyanolyan aktív, újrahasznosítható katalizátornak bizonyultak transzfer hidrogénezésben a fém/PDA/hordozó típusú rendszerek.

A 4-NP transzfer hidrogénezése megfelelő modellreakció egy új katalizátor tesztelésére. Reakciókinetikai vizsgálatokhoz ugyanis ideális reaktáns a $400 \mathrm{~nm}$ hullámhosszon elnyelő 4-NP, míg a redukció során keletkező 4-AP-nak csak $320 \mathrm{~nm}$ alatti hullámhosszakon van elnyelése. Így, a reakció során bekövetkező koncentrációváltozások egyszerűen követhetők egy spektrofotométer segítségével. Azonban, a redukcióhoz a néhány század mmol/ $/ \mathrm{dm}^{3}$ 4-NP koncentráció mellett hatalmas $\mathrm{NaBH}_{4}$ felesleget szoktak alkalmazni, nem ritka a 200 - 1000 ekvivalens sem. ${ }^{[24,25]}$ Ez azért fontos, hogy a kinetikai vizsgálatokban a redukálószer koncentrációját kvázi állandónak tekinthessük, azonban ez az eljárás az esetleges méretnövelést, és laboratóriumi alkalmazást elképzelhetetlenné teszi. Ezzel szemben, csupán elvétve találkozhatunk olyan publikációval, ahol egy új típusú PDA hordozós katalizátor aktivitását optimalizált reakciókörülmények között, több, különböző reaktáns esetén vizsgálták. ${ }^{[24,45,51]}$

Karbonil redukciót, valamint kettős kötés hidrogénezését legjobb tudásunk szerint elöttünk csak egy esetben valósítottak meg fém/PDA rendszerrel. ${ }^{[45]}$ Szén nanocsövön rögzített, karbonsav-alkil-tiol réteggel módosított $\mathrm{Pd} / \mathrm{PDA}$ katalizátorral, hidrogén gázt használva redukálószerként, fahéjaldehidet $80 \%$ szelektivitással 3-fenil-propionaldehiddé tudtak redukálni, miközben melléktermékként megjelent fahéjalkohol és fenilpropanol.

\subsubsection{C-C kapcsolási reakciók}

Szintetikus szempontból a legfontosabb átalakítások közé tartoznak az új C-C kötés kialakításával járó reakciók. Ezek közül a leginkább tanulmányozottak a gyógyszeripar által széles körben alkalmazott Heck és Suzuki reakciók (6. ábra). ${ }^{[52-57]}$ Mindkettőről elmondható, hogy a katalitikus körfolyamat kezdő lépését $\operatorname{Pd}(0)$ indítja (7. ábra), ami bejuttatható a reakcióelegybe $\mathrm{Pd}(\mathrm{II})$-sóként (prekatalizátor), $\mathrm{Pd}(0)$ komplexként, vagy $\mathrm{Pd}$ nanorészecskék formájában. Az első két esetben homogén katalízisről beszélünk, melynek hátránya, hogy stabilizáló ligandumok hiányában (pl. foszfinok) a keletkező $\operatorname{Pd}(0)$ gyorsan aggregál, katalitikusan inaktív ún. palládium korom keletkezik. Hordozó felületen rögzített nanorészecskék esetében az aggregáció jelentősen visszaszorítható, sőt, reakció után a 
katalizátor könnyen eltávolítható a reakcióelegyböl, és akár újra fel is használható, ezért a heterogén katalizátorok fejlesztése napjainkban jelentős figyelmet kap a tudományos szakirodalomban.

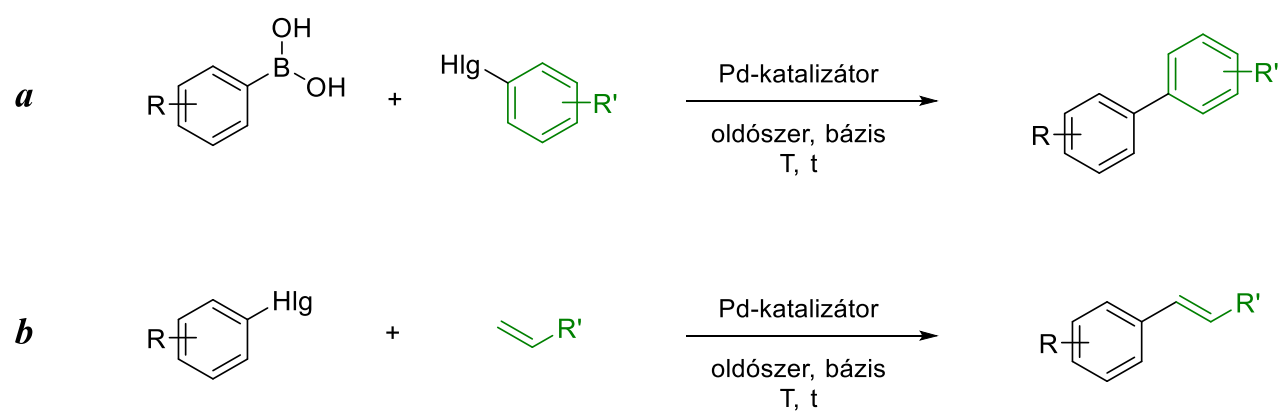

6. ábra (a) Aril-boronsav és aril-halogenid Suzuki reakciója, és (b) aril-halogenid és alkén Heck reakciója, ahol R' = aril-, vagy acilcsoport.

A hordozón rögzített nanorészecskék leoldódása is megtörténhet a reakció során, sőt, feltételezések szerint az oldatban stabilizált nanorészecskék jelenléte szükséges feltétele a Heck reakció lejátszódásának. ${ }^{[57]}$ Továbbá, az oldott $\operatorname{Pd}(0)$ megjelenését az alkalmazott körülmények (pl. oldószer, bázis, adalékanyag) elősegíthetik. Így, a katalitikus transzfer hidrogénezéssel ellentétben, a C-C kapcsolási reakcióknál fokozott problémát okoz a fém leoldódása a hordozóról. Amennyiben a reakció során leoldódott fém nem képes megfelelő diszperzitással readszorbálódni a hordozó felületén, úgy a katalizátor dezaktiválódása történik meg. Ezért a kutatások egyre inkább az aktív komponenst hordozó felület szintézisére koncentrálnak, ami egyre komplexebb, hosszabb, és drágább eljárások kidolgozásához vezet. ${ }^{[58-60]} \mathrm{Ez}$ a megközelítés érthető, ugyanis a hordozó felület jelentős mértékben befolyásolja a rajta keletkező Pd nanorészecskék méretét, geometriáját és stabilitását, ami pedig meghatározza a rendszer aktivitását és szelektivitását. ${ }^{[61,62]}$ Azonban, a bonyolult és drága katalizátorgyártási eljárások az ipar számára már kevésbé vonzóak. 


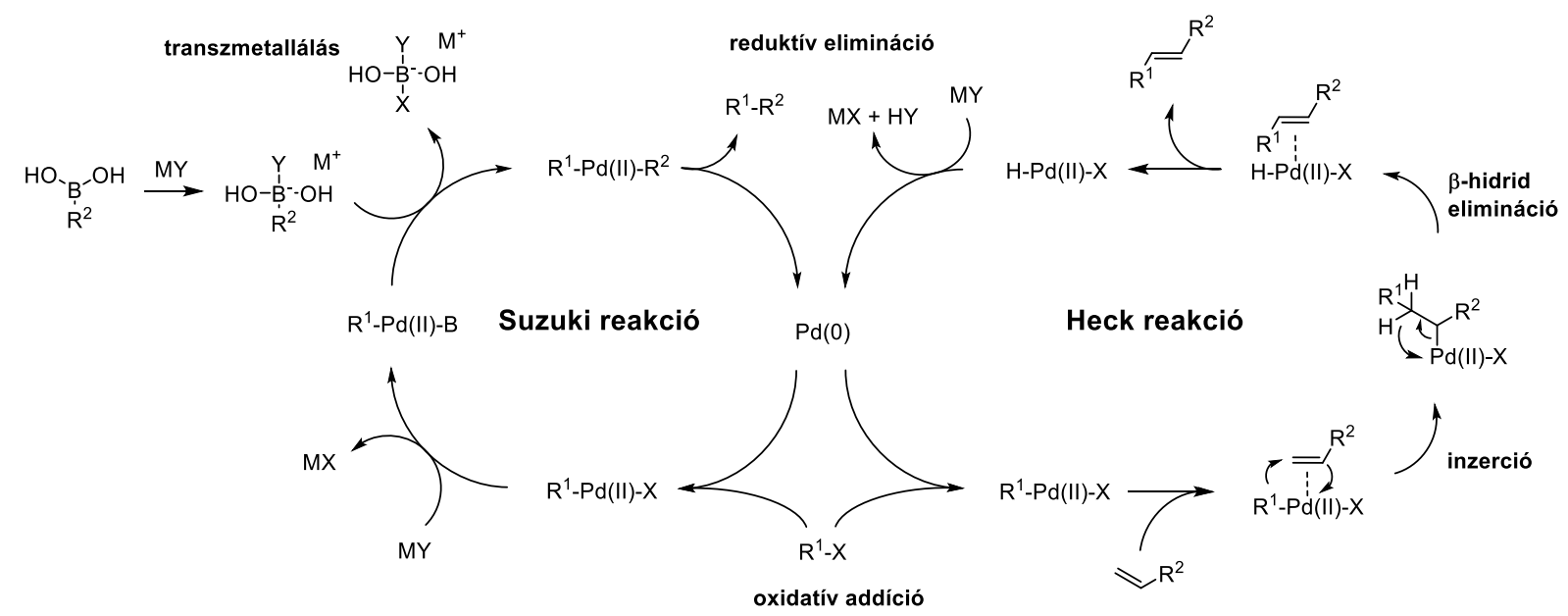

7. ábra Suzuki és Heck reakció mechanizmusának sematikus ábrázolása. Ahol $R^{1}$ és $R^{2}=$ aril (vagy alkil) csoportok; $\mathrm{X}=$ halogén, triflát, vagy egyéb jó távozó csoport; MY = fémsó (pl. karbonát, foszfát), vagy amin.

A PDA használata Pd/PDA(/hordozó) rendszerek előállításában Heck és Suzuki reakciók kivitelezéséhez a korábbi fejezetekben ismertetett univerzális adhezivitása és nanorészecske stabilizáló tulajdonsága miatt előnyösnek bizonyult több esetben. A magnetit $\left(\mathrm{Fe}_{3} \mathrm{O}_{4}\right)$ hordozó használata igen elterjedt, ugyanis megkönnyíti a katalizátor eltávolítását a reakcióelegyből, tisztítását, és további reakciókban való felhasználását. ${ }^{[63-65]}$ PDA-val módosított magnetit nanorészecskékre $\mathrm{NaBH}_{4}$ segítségével $10-70 \mathrm{~nm}$ átmérőjü $\mathrm{Pd}$ részecskéket redukáltak és alkalmaztak Suzuki reakciókban. ${ }^{[63]}$ Fenilboronsav és aril-jodidok reakciójában $80^{\circ} \mathrm{C}$-on, 6 óra reakcióidő után izoláltak nagy kitermeléssel bifenileket, azonban aril-bromidok esetén $100^{\circ} \mathrm{C}$-ra, és 8 - 12 óra reakcióidőre volt szükség a teljes konverzióhoz. Hasonló, PDA/magnetit hordozós rendszereknél, ahol kihasználták a PDA redox-aktivitását és nem alkalmaztak további redukálószert $\operatorname{Pd}(0)$ nanorészecskék előállításához, $8 \mathrm{~nm}^{[64]}$, valamint $4-6 \mathrm{~nm}^{[65]}$ átmérőjü Pd részecskék megjelenését figyelték meg a PDA réteg felületén. Az előbbi esetben $75^{\circ} \mathrm{C}$-on 30 perc, utóbbi esetben $40^{\circ} \mathrm{C}$-on 30 perc -5 óra szükségeltetett a Suzuki reakciók végbemeneteléhez. Ezek a megfigyelések is erősítik a Pd részecskeméret - reaktivitás összefüggés létezését. A hordozó minőségétől függő aktivitást figyeltek meg amennyiben elszenesített szivacsot (Pd@PDA-CL), szilika gélt (Pd@PDASG), valamint polisztirol habot (Pd@PDA-PS) vontak be PDA-val és választottak le Pd-ot a felületekre. ${ }^{[66]}$ Mindegyik katalizátoron egyenletesen eloszló $10-30 \mathrm{~nm}$ átmérőjü Pd nanorészecskéket találtak, azonban szobahőmérsékleten, sötétben 2 óra után modellreakciójukban csak nyomokban volt megfigyelhető termékképződés Pd@PDA-CL esetében, viszont 58 \%-os kitermelést értek el Pd@PDA-SG használatával. Amennyiben fehér 
fénnyel megvilágítva végezték a reakciót, mindkét esetben jelentősen növekedett a kitermelés, 90 \% izolált hozam fölé. A szerzők elmélete szerint a PDA rétegben lyuk-elektron párok generálódtak a fénybesugárzás hatására, ami töltésszeparációt eredményezett, a negatív töltés a Pd nanorészecskéken dúsult fel, ami elősegítette a fém oxidatív addícióját az arilhalogenidre.

Újrahasznosítást segítő megoldásként szilika nanoszálakkal módosított gömblombik belső falára polimerizáltak dopamint és választottak le rá Pd-ot. ${ }^{[67]} \mathrm{A}$ keletkező $\mathrm{Pd}$ nanorészecskék átmérője mindössze 2 nm-nek adódott, és 15 körben aktivitáscsökkenés nélkül újrahasznosítható rendszernek bizonyult Heck reakcióban (teljes konverziók $100^{\circ} \mathrm{C}, 12$ óra alatt), továbbá aktív volt alkén hidrogénezésében, nitrocsoport redukcióban és amidálásban. PDA-val bevont cellulóz nanoszálakból előállított cellulózszivacson a $2-3 \mathrm{~nm}$ es Pd részecskék már $1 \mathrm{mmol} \%$-ban is magas hozamot biztosítottak Suzuki $\left(65^{\circ} \mathrm{C}, 3 \mathrm{~h}\right)$ és Heck $\left(140^{\circ} \mathrm{C}, 6-12 \mathrm{~h}\right)$ reakciókban. ${ }^{[68]}$

\subsubsection{Tandem Suzuki reakció/nitroredukció}

Az egyedényes, többlépéses átalakítások fejlesztésének szükségességét a zöld kémia követelményeinek minél szélesebb körü kielégítése alapozza meg mind laboratóriumi, mind ipari szinten. Ezen előnyök közé tartozik a kevesebb szintetikus lépésnek köszönhető kisebb reaktáns-, valamint oldószerigény, kevesebb hulladék keletkezése, rövidebb szintézis idő, továbbá a kevesebb befektetett energia, ami összességében mind alacsonyabb költségeket eredményez egy totálszintézisre nézve. ${ }^{[69-71]}$

Az aminobifenilek fontos építőkövei egyes gyógyszerhatóanyagoknak, mint például aciltranszferáz inhibitoroknak. ${ }^{[72]}$ Habár a szakirodalomban fém/PDA rendszerrel még nem található Suzuki reakció és nitroredukció egyedényben történt megvalósítása, más katalitikus rendszerekkel már találhatunk kevés számú publikációt.

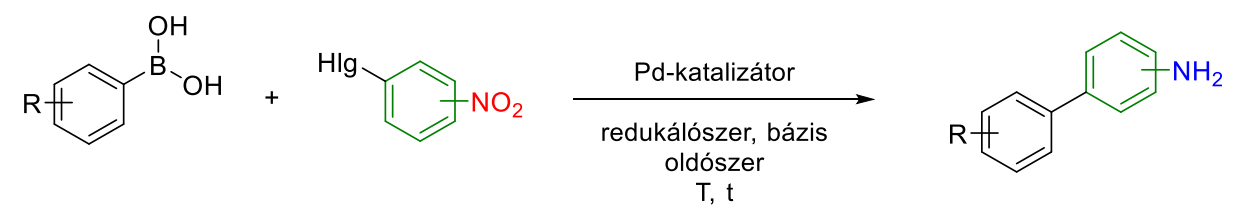

8. ábra Suzuki reakció és nitroredukció egy lépésben, ugyanazzal a katalizátorral végezve.

Tandem, vagy más néven kaszkád reakcióról beszélünk, amennyiben egyedényben, a reakciókörülmények megváltoztatása, valamint további reaktáns hozzáadása nélkül legalább 
kettő konszekutív lépés megvalósul (8. ábra). ${ }^{[73,74]}$ Több publikációban egyszerű egyedényes, szekvenciális Suzuki reakció/nitroredukció metodológiát találunk, ahol a C-C kapcsolás lejátszódása után, második lépésként juttatták a redukálószert $\left(\mathrm{H}_{2},{ }^{[75,}{ }^{76]} \mathrm{NaBH}_{4}{ }^{[77,}{ }^{78]}\right)$ a reakcióelegybe. Wang és munkatársai észrevették, hogy amennyiben nitroaril-halogenidek és arilboronsavak Suzuki reakcióját $\mathrm{DMF} / \mathrm{H}_{2} \mathrm{O} 5: 1$ arányú elegyében hajtották végre $150^{\circ} \mathrm{C}$-on, $\mathrm{Pd}(\mathrm{OAc})_{2}$ katalizátor és $\mathrm{K}_{2} \mathrm{CO}_{3}$ bázis jelenlétében, a termékmolekulán található nitrocsoport is redukálódott. ${ }^{[79]}$ Magyarázattal nem tudtak szolgálni, azonban megfigyelték, hogy arilboronsav, és aril-halogenid hiányában a rendszer nem volt képes nitrobenzolt anilinné redukálni.

Mikrohullám segítségével, mindössze 60 perc reakcióidő alatt értek el magas kitermeléseket tandem Suzuki-, valamint Heck reakció/nitroredukció során mannóz, mint redukálószer, és $\mathrm{Pd}(\mathrm{OAc})_{2}$ (3 mol\%) katalizátor jelenlétében. ${ }^{[80]}$ Szintén csekély reakcióidőt (1 óra), továbbá kis mennyiségű Pd forrást ( $0,73 \mathrm{~mol} \%)$ igényelt hidrazin redukálószer mellett az a tandem Suzuki reakció/nitroredukciós eljárás, amiben könnyen kezelhető, aktívszénnel bevont magnetit részecskéken rögzített kocka alakú $P d$ nanorészecske katalizátort alkalmaztak. ${ }^{[81]}$ Valamiért mégsem vizsgálták újrahasznosíthatóságát tandem reakcióban, kizárólag Suzuki reakcióban. Meglepő módon, csak egyetlen katalitikus rendszer található a szakirodalomban, amelyet tandem Suzuki reakció/nitroredukcióban újrahasznosítottak. ${ }^{[82]} \mathrm{Az}$ említett példában alkalmazott felületmódosított mezopórusos szilika hordozó is csak 3 újrahasznosítási ciklust bírt ki aktivitáscsökkenés nélkül, azonban megjegyzendő, hogy a tandem reakció nem igényelt magas hőmérsékletet, végbement szobahőmérsékleten, 6 óra alatt. 


\subsection{Fotoizomerizálható határfelületek}

\subsubsection{Fotokapcsolók}

Ahhoz, hogy mechanikai vagy kémiai munkavégzésre bírjunk molekulákat, először valamilyen energiaközléssel el kell mozdítanunk őket a termodinamikailag stabil állapotukból. A legkézenfekvőbb energiaforrás, a fény fotonjai által hordozott energia bizonyos molekulákban strukturális változást képes létrehozni, ami egy termodinamikailag magasabb energiájú, metastabil állapotot eredményezhet. Amennyiben ez a folyamat reverzibilis, úgy fotoizomerizálható molekulákról (fotokapcsolókról) beszélünk. ${ }^{[83-86]} \mathrm{A}$ fotokapcsolók iránti érdeklődés folyamatosan növekszik, ugyanis segítségükkel eddig irányíthatatlan rendszereket külső inger hatására irányíthatóvá tudunk tenni. Ilyen például a ki-, és bekapcsolható katalitikus aktivitás, ${ }^{[87-89]}$ farmakológiai hatás, ${ }^{[90,}{ }^{91]}$ vagy a szupramolekuláris rendeződés. ${ }^{[92,}$ 93] A fentebb említett, fény hatására bekövetkező strukturális változás lehet kettőskötés menti E/Z (transz/cisz) izomerizáció (pl. sztilbén, azobenzol; 9. ábra, $a, b)$, vagy konjugált kettőskötésrendszer megváltozása, gyürüzárás/felnyílás (pl. ditienil-etén, spiropirán, donor-akceptor Stenhouse-addukt; 9. ábra, $c, d, e)$.

$a$

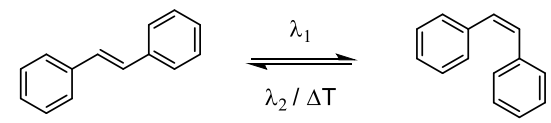

(E)-sztilbén

b

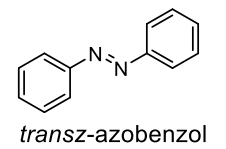

$c$

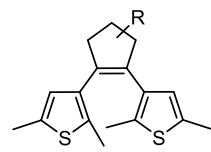

nyílt forma
(Z)-sztilbén
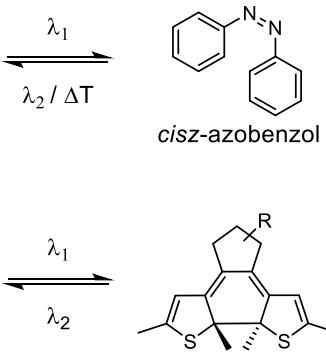

ditienil-etén

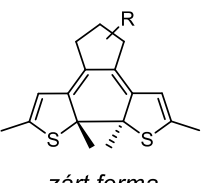

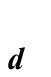

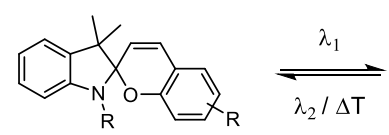

spiropirán

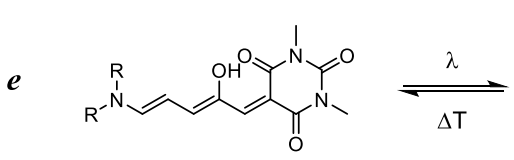

nyilt, trién forma donor-akceptor Stenhouse-addukt

9. ábra Néhány, a szakirodalomban részletesen jellemzett fotokapcsoló.

Mindközül az egyik legszéleskörübben tanulmányozott molekulacsalád az azobenzolegységet tartalmazó fotokapcsolók köre, köszönhetően az egyszerü szintézisüknek, nagy hatásfokú és reverzibilis izomerizációjuknak, valamint az izomerizáció során bekövetkező jelentős méret-, és dipólusmomentum-változásnak. ${ }^{[94]}$ Azobenzolok előállíthatók egy anilinszármazék diazotálásával keletkező aril-diazónium só és egy para-helyzetben 
elektronküldő funkciós csoportot (-OR, $\left.-\mathrm{NR}_{2}\right)$ tartalmazó benzolszármazék azokapcsolásával (10. ábra, $a)$, vagy akár egy nitrozoarén és egy anilinszármazék reakciójával $(10$. ábra, $b) .{ }^{[95]}$

$\boldsymbol{a}$

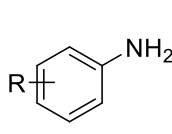

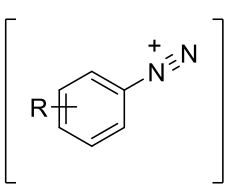

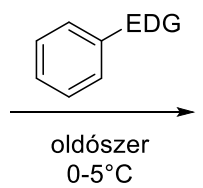<smiles>[R]#Cc1ccc(/N=N/c2ccccc2)cc1</smiles>

$\boldsymbol{b}$<smiles>Nc1ccccc1</smiles>

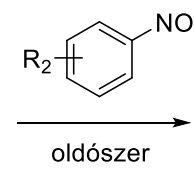

10. ábra Azobenzol származékok előállításának két, gyakran alkalmazott útja. EDG = elektron küldő csoport, pl. -OR, - $\mathrm{NR}_{2}$.

Spektrális tulajdonságaikat tekintve elmondható, hogy a $\pi-\pi^{*}$ átmenethez tartozó jellegzetesen nagy moláris abszorbanciájú elnyelési sáv a közeli UV-tartományba esik (transz-azobenzol: $\lambda_{\pi-\pi^{*}} \approx 320 \mathrm{~nm}$ ), viszont a jelentősen gyengébb $\mathrm{n}-\pi^{*}$ átmenethez tartozó sáv már a látható spektrális tartományhoz tartozik (transz-azobenzol: $\lambda_{\mathrm{n}-\pi^{*}} \approx 450 \mathrm{~nm}$ ). Mivel a cisz-azobenzol elnyelési maximuma is a látható tertományba esik $\left(\lambda_{\max , \text { cisz }} \approx 430 \mathrm{~nm}\right)$, így az azobenzol UV fénnyel szelektíven izomerizálható a cisz formába (11. ábra). A cisz-azobenzol nem csak fehér (kék) fénnyel izomerizálható vissza a transz formába, hanem már szobahőmérsékleten lejátszódó termikus realxációval is visszakaphatjuk a transz izomert, habár ez utóbbi folyamat lassabb. ${ }^{\text {[94] }}$

a

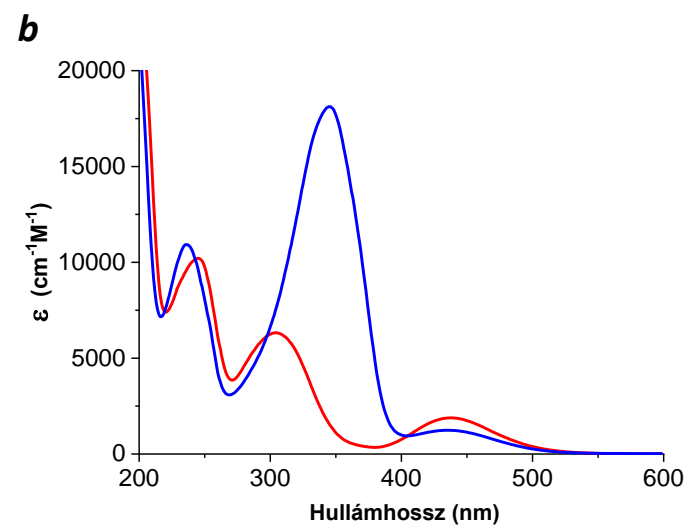

11. ábra Egy azofenol származék $(a)$ izomerizációja, és $(b)$ a két izomer moláris abszorbancia spektruma. 
Különböző szubsztituensek beépítésével ezek az elnyelési sávok eltolhatóak a nagyobb hullámhosszak (alacsonyabb energia) irányába, így lehetővé téve, hogy a fotokapcsoló látható fény hatására képes legyen oda-vissza izomerizálni, ami akár orvosbiológiai használatra is alkalmassá teszi az azobenzolokat. ${ }^{[96]}$ Ilyen változást okoz például a 4-es helyzetben lévő alkoxi-, illetve dialkil-amin szubsztituens (pl. 4'-( $N, N$ dimetilamino)-azofenol: $\left.\lambda_{\pi-\pi^{*}} \approx 440 \mathrm{~nm}\right),{ }^{[94]}$ vagy a 2-2' pozíció etilén-híddal történő összekötése (12. ábra). ${ }^{[97]}$

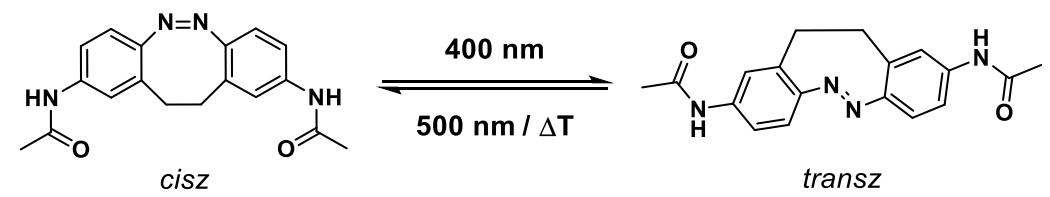

12. ábra Látható fénnyel izomerizálható, 2-2' etilén hidat tartalmazó azobenzol származék. Érdekesség, hogy ebben az esetben a cisz izomer a termodinamikailag stabilabb. ${ }^{[97]}$

\subsubsection{Fotoizomerizáció szilárd határfelületeken}

Ahhoz, hogy megszabaduljunk a fotokapcsolók oldatfázisban jelentkező, rendezetlen Brown-mozgásától, és ezzel ne csak az egyes molekulák izomerizációs képességét tudjuk kihasználni, hanem az együttes, egyirányú mozgásukból adódó lehetőségeket, valamilyen határfelületen kell rögzítenünk a kapcsolóinkat. ${ }^{[98]}$ Egyre növekvő számú publikáció jelenik meg felületen rögzített fotokapcsolókkal megvalósított nedvesedő képesség-kontrollról, ${ }^{[99-103]}$ hatóanyag szállításról, ${ }^{[104-106]}$ molekuláris gépezetek előállításáról, ${ }^{[107-112]}$ valamint felületi mintázat befolyásolásáról. ${ }^{[113-115]}$ Molekulák monomolekulás rétegbe rendezésére leggyakrabban arany felületet használnak, melyhez tiol, vagy amin funkció segítségével rögzíthetők molekulák. ${ }^{[116,}{ }^{117]}$ A fotokapcsolók közül az azobenzolnak a szabad izomerizációhoz legalább $0,45 \mathrm{~nm}^{2}$ alapterületü térrészre van szüksége, ${ }^{[118]}$ ezért ahhoz, hogy sík felületen izomerizálni tudjuk a fotokapcsolóinkat, a megfelelő mértékben el kell távolítanunk őket egymástól. Ehhez vagy higítanunk szükséges a felületi molekularáteget valamilyen alkil-tiollal (13. ábra, $a))^{[119-122]}$ vagy nagy térkitöltésű csoportokat kell beépítenünk a fotokapcsolóba. ${ }^{[123-125]}$ Előbbi megoldás problémája, hogy Au felületen kötött molekulák is elmozdulhatnak, így az azonos kémiai minőségü molekulák között ébredő vonzó kölcsönhatások (pl. $\pi-\pi$ interakció) szigetekbe rendezhetik öket. A szigeteken belül a fotokapcsolók izomerizációja továbbra is gátolt marad. További probléma az alkil-tiol távtartók felületre vitele esetén, hogy adott összetételü alkil-tiol/fotokapcsoló-tiol oldatból 
rendszerint eltérő alkil-tiol/fotokapcsoló-tiol arányú molekularéteg rögzül a felületen, köszönhetően az eltérő felület-affinitásból eredő versengésnek, a molekula-molekula interakciók rendező erejének, valamint az ezekből következő ligandumcsere folyamatoknak. ${ }^{[124,125]}$ A másik lehetőség egy nagy térkitöltésű szubsztituens beépítése a fotokapcsoló molekulába, azonban ez jelentősen növeli a szükséges szintetikus lépések számát, és komplikáltságát.

$a$

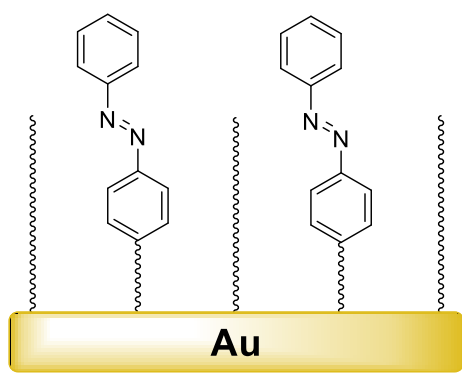

• könnyü kezelhetőség

- együttes, egyirányú méret és polaritás változás

- kis fajlagos felület

- gátolt izomerizáció

- gátolt ligandumcsere $\boldsymbol{b}$

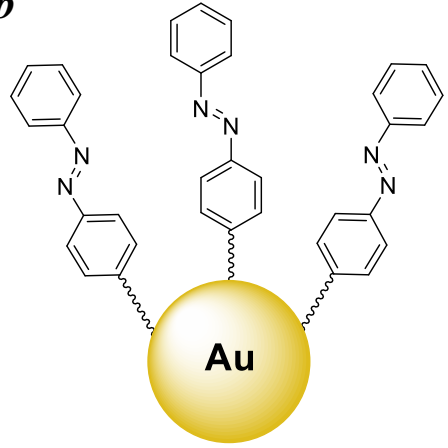

- akadálymentes izomerizáció

- nagy fajlagos felület

- nagy hatásfokú ligandumcsere

- nehéz kezelhetőség

- részecske-aggregáció

13. ábra $(a)$ Sík felületen, valamint $(b)$ nanorészecskén kiépített fotoizomerizálható rendszerek sematikus ábrázolása, valamint ezek előnyei (zölddel) és hátrányai (pirossal).

Mindezekkel ellentétben se „higító” ligandumra, se nagy térkitöltésű szubsztituensekre snincs szükségünk, ha Au nanorészecskéken rögzítjük fotokapcsolóinkat (13. ábra, $b$ ). $\mathrm{Az}$ apró átmérőjü, elegendően nagy felületi görbülettel rendelkező nanorészecskék már biztosítani tudják az azobenzol egység izomerizációjához szükséges szabad térrészt. ${ }^{[126]}$ A nanorészecskék további elönyei közé tartozik, hogy a sík felületekhez képest nagyobb fajlagos felületüknek köszönhetően rajtuk több molekula rögzíthető, így ezek oldatfázisú spektrofotometriai jellemzése egyszerübb, a felületen lejátszódó folyamatok (pl. izomerizáció, ligandumcsere) jobban követhetőek. ${ }^{[127-132]}$ A nanorészecskék kezelése és tárolása viszont nehézkes, müveletek közben irreverzibilisen aggregálódhatnak, elveszítve ezzel funkciójukat. Mindebből az következik, hogy fotoizomerizálható szilárd határfelületek előállítása és jellemzése jelentős technikai és szintetikus kihívást jelent. 


\subsubsection{Ligandumcsere szilárd határfelületeken}

Határfelületen rögzített ligandum valamilyen más fizikai vagy kémiai tulajdonságú ligandumra történő részleges vagy teljes cseréjével megváltoztathatjuk a felület makroszkopikus tulajdonságait. Az ilyen, újrakonstruálható felületet akár több, különböző fizikai vagy kémiai feladat elvégzésére is felhasználhatjuk anélkül, hogy építőelemeiből újra és újra össze kellene állítanunk.

Az ilyen, újrakonstruálható felület létrehozása nem egyszerü feladat. Módosított kvarc felületen, diszulfid híddal rögzített molekulák cserélhetőségét valósították meg Yu és munkatársai. ${ }^{[131]}$ Azonban, a felületre vitt fotoizomerizálható molekula mozgatására alkalmas UV fény hatására következett be a diszulfid-híd hasítása is, tehát a felületen rögzített molekulák eltávolítása, így az új fizikai feladat elvégzésére képes rendszer nem müködött.

Diszulfid híd kiépítése helyett felhasználhatjuk az $\mathrm{Au}-\mathrm{S}$ között ébredő erős interakciót, mint ligandumrögzítő kölcsönhatást. Általánosságban elmondható, hogy Au felületen a ligandumcsere gyorsítható a felületen és az oldatban lévő ligandumok közötti koncentrációkülönbséggel, a hőmérséklet emelésével, továbbá, hogy a csere minden esetben a felületi egyenetlenségeken kezdődik, és lassulva tart a nagyobb rendezettségü, sík részek felé. $^{[132-134]}$ Ezt jól illusztrálja Picardi és munkatársainak munkája, melynek során tioalkán/tioalkil-azobenzol cserét vizsgáltak polikristályos $\mathrm{Au}$ felületen. ${ }^{[135]}$ A ligandumcsere ebben az esetben is elsősorban a kristályok szélein játszódott le, az egyenetlenségektől távoli sík felszínen viszont meglehetősen gátolt volt a folyamat (14. ábra). Habár érdekes lett volna, de a keletkezett kevert ligandumréteg azobenzol egységeinek izomerizációs képességét nem vizsgálták.
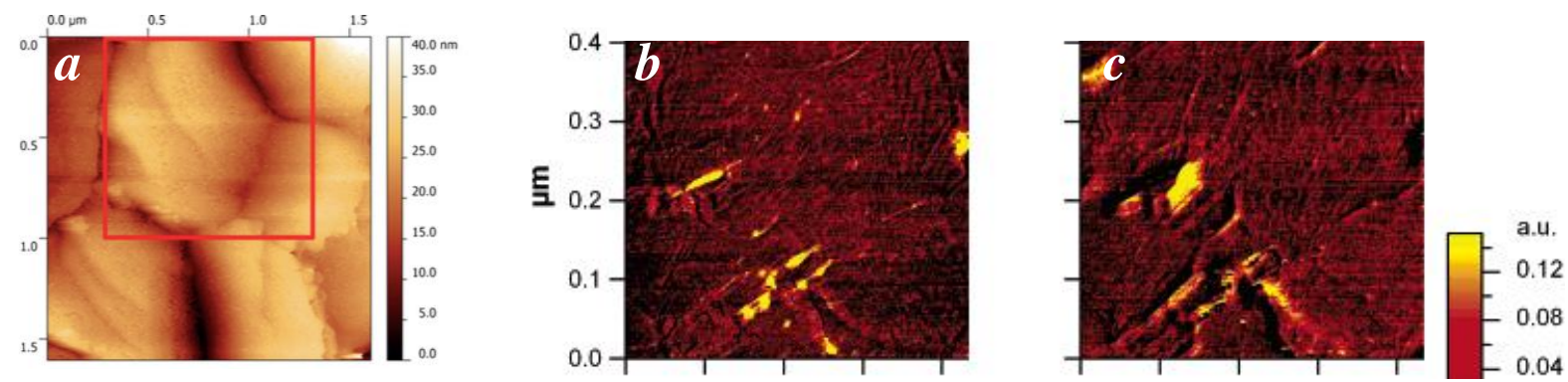

14. ábra $(a)$ Polikristályos $\mathrm{Au}$ felület STM mikroszkópos képe, ${ }^{[135]}$ és $(b, c)$ sík Au felület AFM képe. ${ }^{[133]}$ Mindkét esetben láthatunk kristályszéleket, teraszokat, hibahelyeket, valamint nagy rendezettségü, sík felületeket, amelyeken eltérő sebességgel történik meg a ligandumcsere. 
$\mathrm{Au}$ nanorészecskéken végrehajtott ligandumcsere gyorsabb, jobb hatásfokú, mint sík felületen, továbbá a felületre vitt fotoizomerizálható egység számára elegendő teret biztosít a nanorészecske felületi görbülete. Kétkomponensű molekularéteget tartalmazó Au nanorészecskéket állítottak elő Klajn és munkatársai tiol terminális azobenzol ligandumok cseréjével, így kék-, valamint UV-fény hatására aggregáló, hő hatására deaggregáló „frusztrált” nanorészecskéket kaptak (15. ábra). ${ }^{[136]}$ Azonban megfigyelésük szerint a ligandumcserét $31 \%$ körül le kellett állítaniuk, különben a nanorészecskék precipitációja következett be az alkalmazott toluol/hexán 7/3 elegyböl. További hátrányt jelentett, hogy a ligandumcsere előtt és után is több centrifugálás/mosás is szükséges volt, ami körülményessé tette a szintézist. Későbbi publikációjukban hidrofil ligandumokat rögzítettek azobenzol származékokat tartalmazó $\mathrm{Au}$ nanorészecskéken, így nem csak vizes közegben stabil nanorészecskéket kaptak, de megfigyelték, hogy hidroxil-csoportot tartalmazó „háttér” ligandumok akár 6000-szeresére is gyorsíthatják a felületi azobenzolok termikus cisz $\rightarrow$ transz izomerizációját. ${ }^{[137]}$
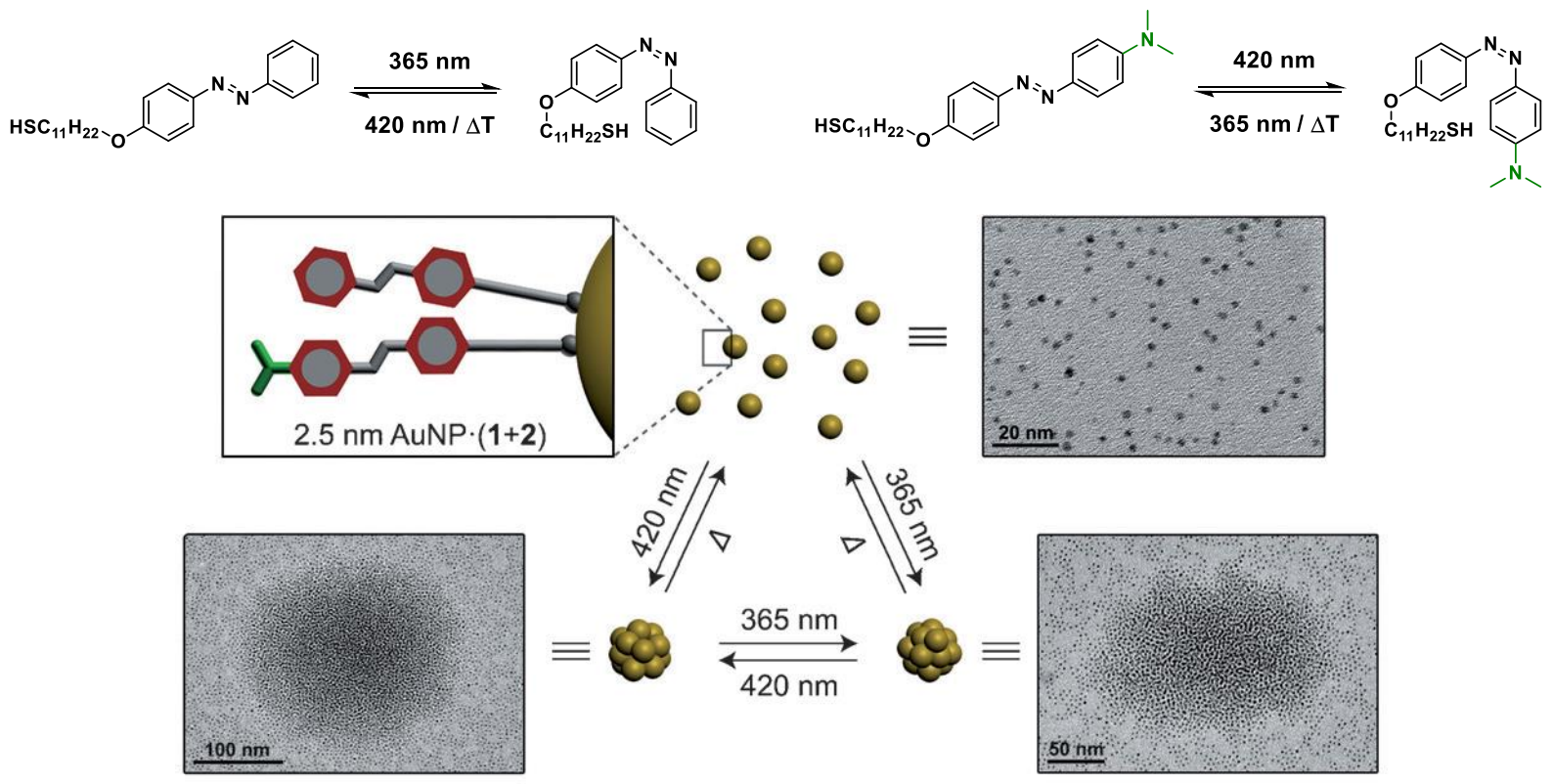

15. ábra Két, eltérő hullámhosszon izomerizáló fotokapcsolót tartalmazó „frusztrált” $\mathrm{Au}$ nanorészecskék. Fénybesugárzás hatására aggregálódnak, termikusan (az azobenzol származék cisz $\rightarrow$ transz relaxációja során) deaggregálódnak. ${ }^{[136]}$ 


\section{Célkitǔzések}

Ismerve a szakirodalomban megmutatkozó Pd részecskeméret - katalitikus aktivitás összefüggést, mindenekelőtt célunk volt létrehozni a lehető legkisebb átmérőjü $\mathrm{Pd}$ nanorészecskéket PDA felületen, kihasználva a PDA redukáló képességét. Az így nyert Pd/PDA kompozit katalitikus aktivitását vizsgálni kívántuk katalitikus transzfer hidrogénezési és C-C kapcsolási reakciókban. Mivel egy új típusú heterogén katalizátor jellemzésénél az egyik legfontosabb kérdéskör az újrahasznosíthatóság, ezért kihasználva a PDA univerzális adhezivitását, a katalizátor kezelhetőségét segítő magnetit részecskén kiépített Pd/PDA rendszer aktivitását és újrahasznosíthatóságát is felderíteni terveztük.

További célul tűztük ki egy könnyen előállítható, PDA alapú, fotoizomerizálható határfelület létrehozását. Felhasználva a Pd/PDA jellemzése során megszerzett morfológiai és stabilitási ismereteket, PDA-n rögzített Au nanorészecskékre kívántunk felvinni azobenzol származékokat, és vizsgálni az így nyert PDA-Au-molekula kompozit felületek fotoizomerizáció során bekövetkező fizikai tulajdonságainak változását. Emellett, a felületen elhelyezkedő ligandum molekulák cserélhetőségét kívántuk felderíteni. 


\section{Eredmények és kiértékelésük}

\subsection{Katalízis Pd/PDA rendszerekkel ${ }^{[138,139]}$}

Egy Pd tartalmú heterogén katalizátor tulajdonságait nagymértékben meghatározza a hordozó kémiai minősége, és a fém nanorészecske hordozóra való felvitelének módja. Ezek a körülmények befolyásolhatják a keletkező kompozit stabilitását, katalitikus aktivitását, újrahasznosíthatóságát. Ezeket szem előtt tartva igyekeztünk létrehozni Pd nanorészecskéket tartalmazó PDA hordozós katalizátort (Pd/PDA), valamint ennek magnetit részecskén (MNP - Magnetite NanoParticle) rögzített analógját (Pd/PDA/MNP), (16. ábra) és felderíteni alkalmazhatóságukat, valamint újrahasznosíthatóságukat különböző katalitikus átalakításokban.

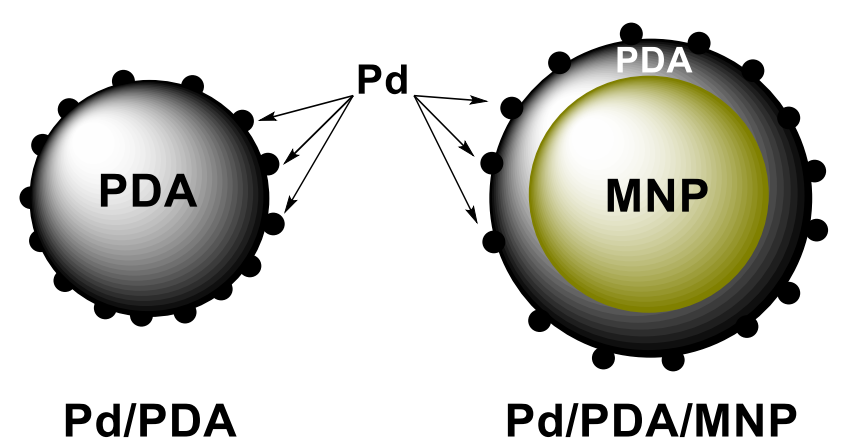

16. ábra Az előállítani kívánt katalizátorok sematikus ábrázolása.

\subsubsection{Pd nanorészecskék létrehozása PDA felületen}

A Katalízis fém/PDA rendszerekkel fejezetben ismertetett, Suzuki reakciót leíró irodalmakban megmutatkozó Pd részecskeméret - aktivitás összefüggés alapján először olyan eljárást kerestünk, amellyel a lehető legkisebb átmérőjű Pd nanorészecskék hozhatóak létre PDA felületen. Ehhez PDA részecskéket állítottunk elő dopamin-hidrokloridból. Oldószerként vizet használva, Tris bázis jelenlétében, aerob körülmények között 30 óra alatt 150 - 250 nm átmérőjü PDA gömböket tartalmazó aggregátumok keletkeztek. (17. ábra, $a, b$, c) 

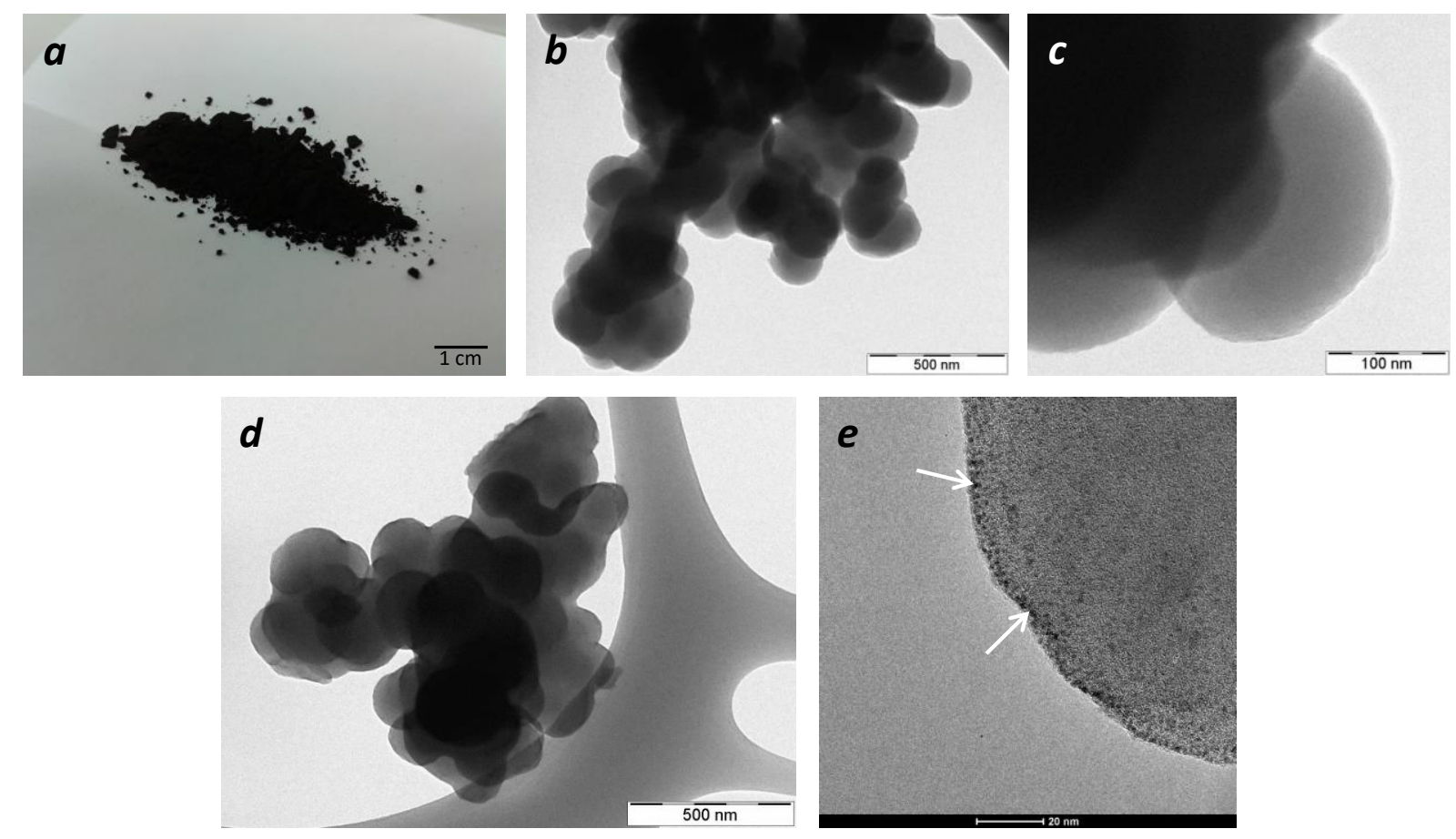

17. ábra $(a)$ PDA por makroszkopikus képe; $(b, c)$ PDA TEM képe különböző nagyítás mellett; $(d, e)$ Pd/PDA TEM képe. A nyíllal jelzett apró, sűrün elhelyezkedő fekete foltok a pár nm-es Pd nanorészecskék.

$\operatorname{Pd}(0)$ prekurzornak $\mathrm{Pd}(\mathrm{OAc})_{2}$-ot választottunk, melynek különböző oldószerekből készült oldataiban szuszpendáltuk az elöállított PDA részecskéket, majd szobahőmérsékleten kevertettük a reakcióelegyeket 16 órán át. Mivel hexánban és toluolban nem, vagy csak elhanyagolható mértékben oldódott a $\mathrm{Pd}(\mathrm{OAc})_{2}$, ezért a vizsgálatainkat leszükítettük a polárisabb karakterü oldószerekre. TEM és ICP vizsgálatok alapján megállapítottuk, hogy aceton és $i$-propanol esetén a hordozón keletkezett Pd nanorészecskék átlagos átmérője $8-15$ $\mathrm{nm}$ körül alakult, acetonitrilt használva kisebb, $4-5 \mathrm{~nm}$-es részecskék megjelenését tapasztaltuk, azonban alacsonyabb koncentrációban $(<1 \mathrm{~m} / \mathrm{m} \%)$. Metanolt használva oldószerként, nagy diszperzitású, $1-3 \mathrm{~nm}$ átmérőjü $\mathrm{Pd}$ nanorészecskék megjelenését tapasztaltuk a polimer felületén $3,03 \mathrm{~m} / \mathrm{m} \%$ koncentrációban. A 17. ábra, $e$ részén látható apró átméröjü nanorészecskék jelenléte nem gyakori jelenség a fémkatalízissel foglalkozó szakirodalomban, csupán kis mennyiségü publikáció található, amiben hasonló mérettartományú Pd részecskék aktivitását jellemzik. ${ }^{[140,141]}$ Az eredmények tükrében további optimalizálást nem végeztünk, katalitikus reakcióink során a metanolos rendszerben elóállított 1 - 3 nm-es Pd nanorészecskéket tartalmazó Pd/PDA katalizátort használtuk fel. A különböző átmérőjü Pd nanorészecskék katalitikus aktivitásában megfigyelt különbségekről a Suzuki reakcióval foglalkozó alfejezetben teszünk említést. 
A katalizátor újrahasznosíthatóságát megkönnyítendö, előállítottunk PDA-val bevont magnetit magon rögzített Pd nanorészecskéket tartalmazó katalizátort (Pd/PDA/MNP) is (18. ábra). Ebben az esetben $\mathrm{Fe}_{3} \mathrm{O}_{4}$ nanorészecskék vizes szuszpenziójában végeztük a dopamin polimerizációját, ami 20 - 30 nm-es PDA réteggel borította be a magnetit magokat. Az így nyert polimer réteg redox aktív maradt, viszont az előbbiekben megfigyelt $1-3 \mathrm{~nm}$-es Pd nanorészecskék helyett $5-8 \mathrm{~nm}$-es részecskék keletkeztek a PDA réteg felületén. Ennek oka, sejtéseink szerint, a $\mathrm{Fe}_{3} \mathrm{O}_{4}$-on másképp rendeződő polimer szálak csökkent Pd részecske koordináló/stabilizáló képessége lehet.
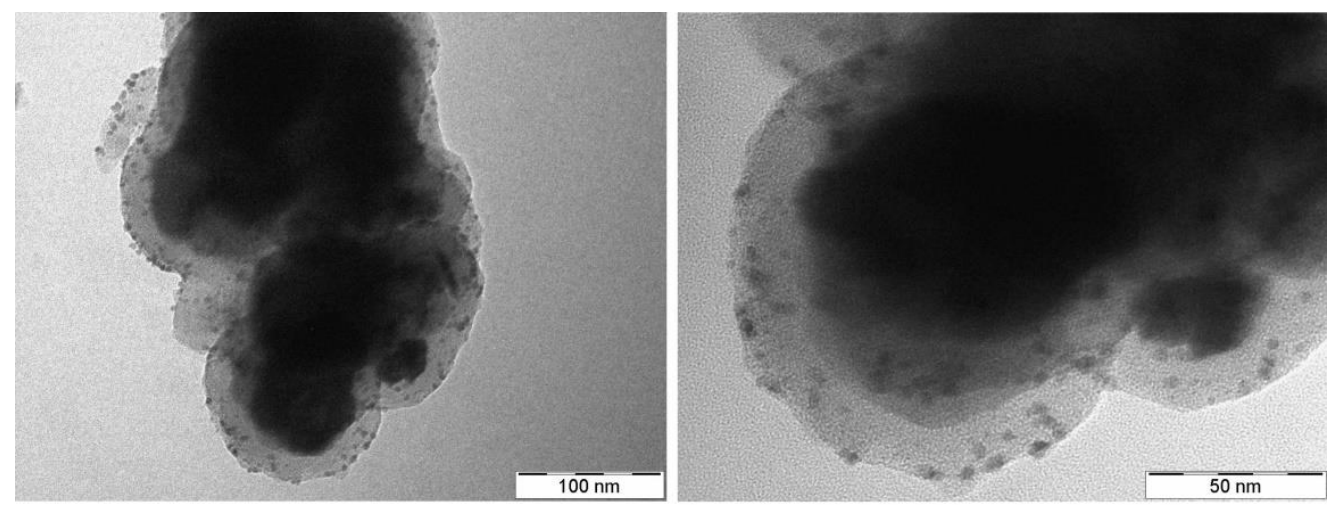

18. ábra $\mathrm{A} \mathrm{Pd} / \mathrm{PDA} / \mathrm{MNP}$ katalizátor TEM képe. Az elektronsugár számára átlátszatlan magnetit magot $\approx 20-30 \mathrm{~nm}$ vastagságú PDA réteg veszi körül, amelyen $5-8 \mathrm{~nm}$-es Pd nanorészecskék láthatóak.

XPS vizsgálatok alapján jelentős különbség nem figyelhető meg a PDA, Pd/PDA, és a Pd/PDA/MNP katalizátorokon a polimerre jellemző elemek összetételében, ami megegyezik a szakirodalomban leírt megfigyelésekkel is. ${ }^{[143,144]}$ Fontos eredmény, hogy a maximálisan 10 $20 \mathrm{~nm}$ mélységig detektáló XPS alapján a Pd mennyisége 25 - $30 \mathrm{~m} / \mathrm{m} \%$-nak látszott az az előállítás során $5 \mathrm{~m} / \mathrm{m} \%$-ban hozzáadott Pd-mennyiséghez képest, ami azt jelenti, hogy a Pd nagyobbrészt a felületen helyezkedett el. A Pd/PDA/MNP katalizátor XP spektrumán nem található Fe-hoz tartozó jel, ami arra utal, hogy a magnetit részecskék legalább $15 \mathrm{~nm}$ vastag PDA réteggel borítottak. Érdekes megfigyelést tettünk a Pd nanorészecskék oxidációs állapotának vizsgálatakor. $\mathrm{Pd} / \mathrm{PDA}$ esetén a $\mathrm{Pd}$ nagyrésze $(\approx 80 \%) \mathrm{PdO}_{2}$, kisebb hányada $(\approx$ $10 \%)$ PdO-hoz rendelhető eltolódással jelent meg az XP spektrumon, míg a Pd/PDA/MNP Pd tartalma közel fele $\operatorname{Pd}(0)$, másik fele valamilyen oxidáltsági fokú $(+2,+4)$ Pd-oxid formájában jelent meg (19. ábra). Ezt a jelenséget szintén a Pd méretéhez lehet kötni. ${ }^{[145,146]}$ Apró, $1 \mathrm{~nm}$ körüli Pd nanorészecskék levegő jelenlétében hajlamosabbak oxidációra, ellentétben a nagyobb, 2 - 4 nm körüli, és az afeletti átmérővel rendelkezőkkel. 


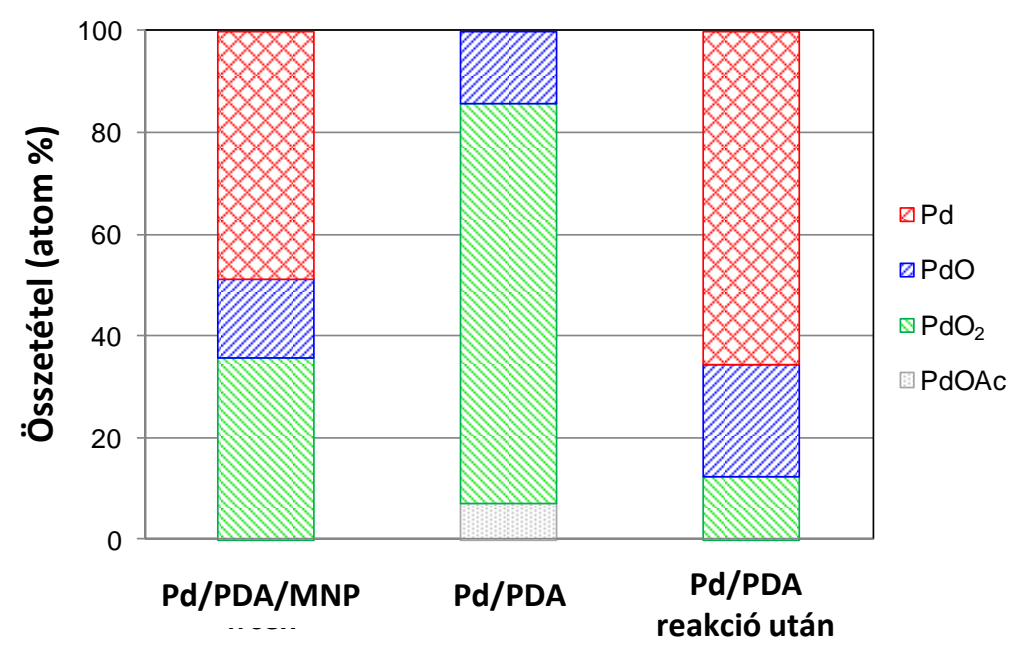

19. ábra $A$ katalizátorok felületén talált $P d$ minőségének megoszlása atom\%-ban kifejezve reakció előtti, valamint Pd/PDA Pd összetétele transzfer hidrogénezés utáni XPS mérések alapján.

\subsubsection{Katalitikus transzfer hidrogénezés}

A nitroaril vegyületek nitrocsoportjának redukciója a legelterjedtebb tesztreakciók közé tartozik egy új típusú heterogén, átmenetifém katalizátor jellemzésében. Amint azt az irodalmi elözmények tárgyalásánál bemutattuk, a különböző Pd/PDA/hordozó rendszerek katalitikus aktivitásai között a nitroredukcióban jelentős eltérés nem található, azonban vizsgálatuk szélesebb szubsztrátkörön egy esetben sem történt meg. Ezért, modellvegyületként 4-nitro-etilbenzoátot (1) választva, először optimalizáltuk az általunk előállított $\mathrm{Pd} / \mathrm{PDA}$ által katalizált nitroredukciót, majd kiterjesztettük vizsgálatainkat különböző funkcióscsoportot tartalmazó vegyületekre. Modellvegyületünk redukciója során keletkező 4-amino-etilbenzoát (2), más néven benzokain, egy lokális érzéstelenítő, amit napjainkban is használnak különböző füll-orr-gégészeti, fogászati beavatkozásoknál, valamint gyógyszerhatóanyagként (pl. Dorithricin). 
1. Táblázat Pd/PDA által katalizált transzfer hirdogénezés optimalizálása.

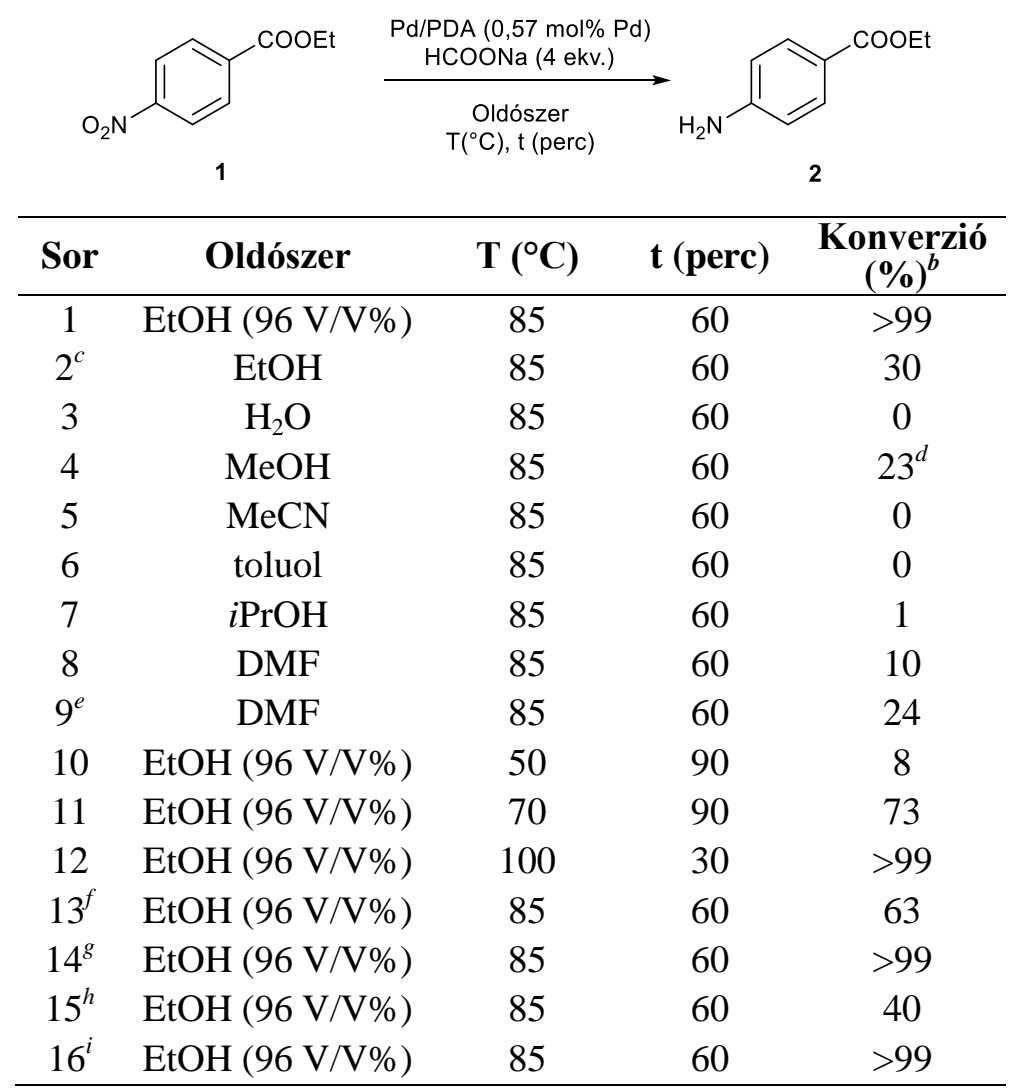

a Általános reakciókörülmények: Pd/PDA (10 mg, 0,57 mol\% Pd), 4-nitro-etilbenzoát (98 mg, 0,5 mmol), HCOONa (136 mg, 2,0 mmol), oldószer $(2 \mathrm{ml}) .{ }^{b}$ A nitrovegyület konverziója; GC-MS-el meghatározva. ${ }^{c}$ Abszolutizált oldószert használva. ${ }^{d}$ 4-amino-metilbenzoát keletkezett $75 \%$ szelektivitással. ${ }^{e} 4 \mathrm{~V} / \mathrm{V} \%$ vizet hozzáadva. ${ }^{f} 2$ ekv. HCOONa-t használva. ${ }^{g} 6$ ekv. HCOONa-t használva. ${ }^{h} 1 \mathrm{~mol} \% \mathrm{Pd}(\mathrm{OAc})_{2}$-t használva katalizátorként. ${ }^{i} 1 \mathrm{~mol} \% \mathrm{Pd}(\mathrm{OAc})_{2}+10 \mathrm{mg}$ PDA-t használva katalizátorként.

Teljes konverziót $85^{\circ} \mathrm{C}$-on, 60 perc után, $96 \mathrm{~V} / \mathrm{V} \%$-os EtOH oldószert használva tapasztaltunk (1. táblázat, 1. sor). Amennyiben vízmentes EtOH-t alkalmaztunk, a konverzió 30 \%-ra csökkent (1. táblázat, 2. sor), valószínűleg a HCOONa kisebb oldhatósága miatt. Vizet használva oldószerként, azonban egyáltalán nem tapasztaltunk átalakulást (1. táblázat, 3. sor). Alacsony konverzió (23\%) mellett $75 \%$ szelektivitással az átésztereződött termék megjelenését figyeltük meg MeOH-ban (1. táblázat, 4. sor). Semmilyen átalakulás nem történt, vagy csak nyomnyi termék jelent meg MeCN-ben, toluolban, és iPrOH-ban (1. táblázat, 5-7. sor), amit szintén a HCOONa oldhatóságának tulajdonítunk. DMF esetén enyhe konverziónövekedést tapasztaltunk $10 \%$-ról $24 \%$-ra, amennyiben 4 V/V\% vizet adtunk a reakcióelegyhez (1. táblázat, 8, 9. sor). Ezen eredmények tükrében 96 V/V\%-os EtOH-t választottunk oldószernek a további vizsgálatainkhoz. A reakció hőmérsékletét 50, illetve $70^{\circ} \mathrm{C}$-ra csökkentve, meg kellett növelnünk a reakcióidőt 90 percre, azonban így is a 
konverzió 8, valamint $73 \%$-ra csökkenését tapasztaltuk (1. táblázat, 10, 11. sor). Ezzel szemben $100^{\circ} \mathrm{C}$-on már 30 perc alatt végbement a redukció (1. táblázat, 12. sor). A redukálószerből 2 ekvivalenst használva a reakció $63 \%$ környékén megállt, 6 ekvivalens használata viszont nem befolyásolta a reakció végbemenetelét a 4 ekvivalens alkalmazásához képest (1. táblázat, 13, 14. sor). Összehasonlításképpen $\mathrm{Pd} / \mathrm{PDA}$ helyett $\mathrm{Pd}(\mathrm{OAc})_{2}$-ot használva katalizátorként az optimalizált körülmények között csupán 40 \% konverziót értünk el, azonban PDA-t adva a reakcióelegyhez ugyanúgy 1 teljes átalakulását értük el, mint Pd/PDA jelenlétében (1. táblázat, 14, 15. sor). Ennek magyarázata az lehet, hogy az adott körülmények közt a PDA redukálja a Pd(II)-t, in situ Pd/PDA-t képezve, ami jobb katalizátora a transzfer hidrogénezésnek, mint önmagában a $\mathrm{Pd}(\mathrm{OAc})_{2}$, vagy a belőle keletkező $\mathrm{Pd}(0)$ valamilyen diszpergált formája. Érdemes megemlíteni, hogy egyik vizsgált körülmény sem vezetett az észter funkció redukciójához, továbbá a katalizátor, vagy a redukálószer hiányában nem tapasztaltunk reakciót.

A fenti eredmények alapján, az 1. táblázat 1. sorában ismertetett körülményeket használva folytattuk munkánkat, amelynek során különböző funkciós csoportokat tartalmazó aromás nitrovegyületek átalakulásait vizsgáltuk. Megállapítottuk, hogy elektronküldő, valamint elektronszívó szubsztituensek nem voltak hatással a reaktivitásra, közel teljes konverzió mellett magas kitermelést eredményeztek (20. ábra, 2-10). Amid és észter funkció redukcióját nem tapasztaltuk (20. ábra, 2, 9). 4-Nitro-benzaldehid esetén nem történt átalakulás (20. ábra, 11), aminek magyarázata lehet, hogy az adott körülmények között az aldehid imint képez a PDA szabad aminjaival ${ }^{[19]}$, így sztérikusan gátolja további reaktáns kötődését a Pd nanorészecskékhez. Hasonlóan katalizátorméregnek bizonyult a nitrilcsoport jelenléte is (20. ábra, 12). Ennek igazolásához nitrobenzol és 4-nitro-benzonitril 1:1 arányú elegyét az optimalizált körülmények között reakcióba víve, a nitrobenzol anilinné történő redukcióját 1 óra eltelte után sem tapasztaltuk, pedig azonos körülmények között, 4-nitrobenzonitril hiányában teljes konverziót figyeltünk meg. 


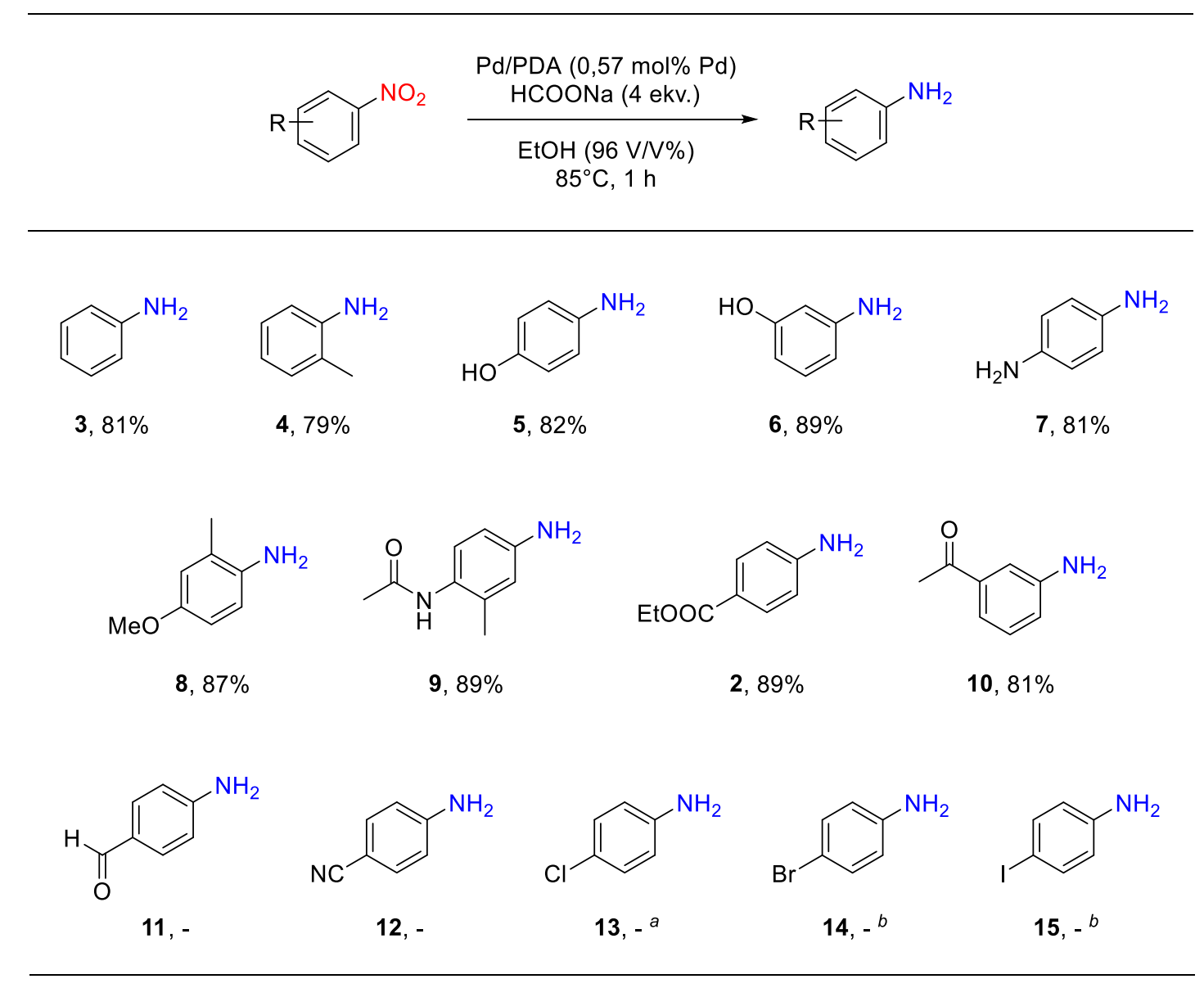

20. ábra Nitroaril vegyületek $\mathrm{Pd} / \mathrm{PDA}$ által katalizált transzfer hidrogénezése. Általános reakciókörülmények: Pd/PDA (10 mg, 0,57 mol\% Pd), reaktáns (0,5 mmol), HCOONa (136 mg, 2,0 $\mathrm{mmol}), 96 \mathrm{~V} / \mathrm{V} \% \mathrm{EtOH}(2 \mathrm{ml}), 85^{\circ} \mathrm{C}, 60$ perc. A feltüntetett értékek izolált hozamok. ${ }^{a} 32 \%$ nitrobenzol keletkezett. ${ }^{b}<5 \%$ nitrobenzol keletkezett.

Para-halo-nitrobenzolok közül a 4-klór-nitrobenzol esetén 32 \%-ban nitrobenzol melléktermék megjelenését tapasztaltuk. Br, és I-szubsztituált nitrobenzolok redukciója nem történt meg, viszont nyomokban itt is dehalogénezett melléktermékek megjelenését detektáltuk (20. ábra, 13 - 15). Ennek oka az lehet, hogy a $\operatorname{Pd}(0)$ aril-bromidokra és jodidokra történő oxidatív addíciója olyan gyors és nagymértékű a nitroredukcióhoz képest (lásd a Suzuki reakció alfejezetben), hogy a hidrogénforrás HCOONa már nem fér hozzá a Pd nanorészecskékhez, a reakció megáll. Ezt az elképzelést támasztja alá Dehury és munkatársainak megfigyelése tandem Suzuki/transzfer hidrogénezés reakciók esetén, ugyanis a redukciót találták sebességmeghatározó (tehát lassabb) lépésnek a kompetitív Suzuki reakcióval szemben. ${ }^{[142]}$

Fontos megemlítenünk, hogy 3-nitro-acetofenon (21. ábra, 16) redukciója során nyomnyi mennyiségben 3-amino-feniletanol (21. ábra, 17) megjelenését figyeltük meg. 
Amennyiben megnöveltük a HCOONa mennyiségét 6 ekvivalensre, a teljesen redukált 3amino-feniletanol $32 \%$-ban izolálható volt 2 óra reakcióidő után (21. ábra).

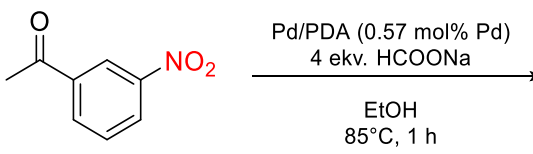

16

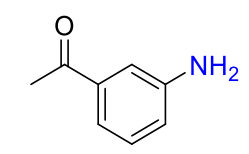

10

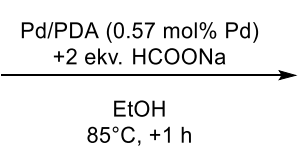

$85^{\circ} \mathrm{C},+1 \mathrm{~h}$

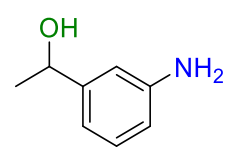

$17,32 \%$

21. ábra 3-nitro-acetofenon karbonil funkciójának redukciója a redukálószer mennyiségének és a reakcióidő növelésének hatására.

E megfigyelés alapján megvizsgáltuk további karbonil funkciót tartalmazó vegyületek viselkedését transzfer hidrogénezésben, 6 ekvivalens HCOONa jelenlétében, a megnövelt, 2 óra reakcióidővel.

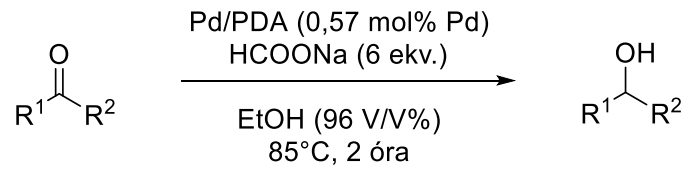

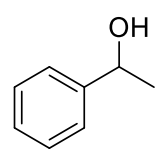

$18,88 \%$<smiles>COc1ccc(C(C)O)cc1</smiles>

$19,18 \%$ a<smiles>CC(O)c1ccc(Cl)cc1</smiles>

$20,0 \%$ b

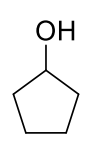

21, $0 \%$<smiles>OC(c1ccccc1)c1ccccc1</smiles>

$22,90 \%{ }^{a}$<smiles>OC/C=C/c1ccccc1</smiles>

23, $0 \%$

22. ábra Karbonil-vegyületek $\mathrm{Pd} / \mathrm{PDA}$ által katalizált transzfer hidrogénezése. Általános reakciókörülmények: Pd/PDA (10 mg, 0,57 mol\% Pd), reaktáns (0,5 mmol), HCOONa (204mg, 3,0 mmol), $96 \mathrm{~V} / \mathrm{V} \% \mathrm{EtOH}(2 \mathrm{ml}), 85^{\circ} \mathrm{C}, 2 \mathrm{~h}$. A feltüntetett értékek izolált hozamok. ${ }^{a}$ Reakcióidő: $5 \mathrm{~h}$, a termékarány ${ }^{1} \mathrm{H}$ NMR spektroszkópiával lett meghatározva. ${ }^{b}$ Acetofenon keletkezett $85 \%$ hozammal.

Az acetofenon reaktívabbnak bizonyult a többi karbonil vegyülethez képest (22. ábra, 18). Öt óra reakcióidő szükségeltetett a benzofenon redukciójához, azonban a 4-metoxiacetofenon konverziója ez idő után is alacsony maradt (22. ábra, 22, és 19). 4-klór- 
acetofenonnál csak a deklórozódást figyeltük meg, míg a ciklopentanon nem alakult át a reakció körülményei között (22. ábra, 20, és 21). Fahéjaldehid esetén az átalakulás hiányát a katalizátorral történő imin képződésen keresztüli lemérgeződéssel magyarázhatjuk (22. ábra, 23), úgy mint a 4-nitrobenzaldehid reakciójában.

Egy heterogén katalizátor leghasznosabb tulajdonsága az újrahasznosíthatóság. Mivel a Pd/PDA egy finom szemcséjü por, ez nehézkessé teszi elválasztását a reakcióelegytől. Kihasználva a PDA univerzális adhezivitását, a szakirodalomban egyre szélesebb körben alkalmazott $\mathrm{Fe}_{3} \mathrm{O}_{4}$ részecskéket borítottunk be PDA-val, amire Pd-ot redukáltunk. Az így létrehozott katalizátor külső mágneses térrel összegyüjthetővé vált, elválasztva ezzel a termékelegytöl, megkönnyítve annak további tisztítását (23. ábra).
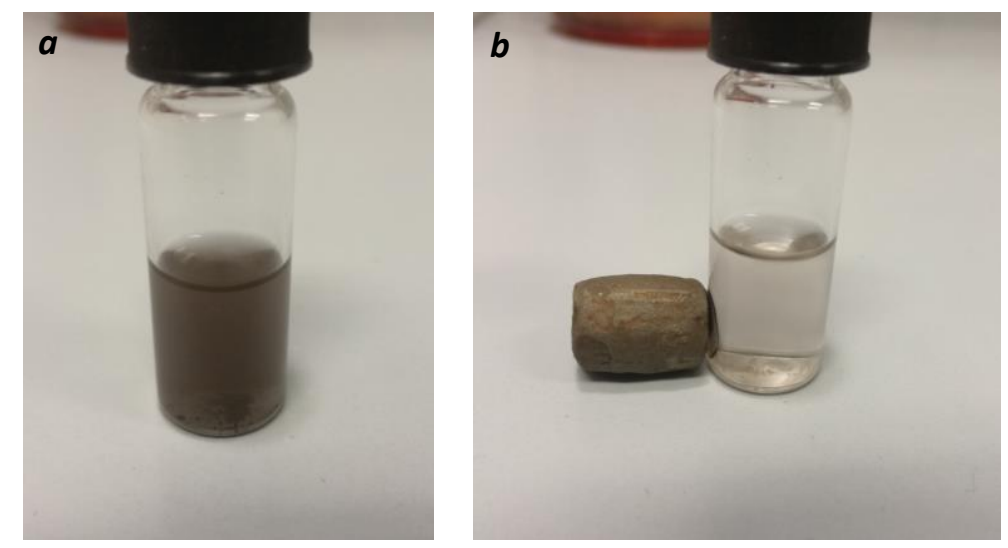

23. ábra (a) Pd/PDA/MNP etanolos szuszpenziója, $(b)$ külső mágneses tér hatására a katalizátor a fiola falához tapad.

ICP-MS analízis alapján a Pd/PDA/MNP katalizátor Pd tartalma 1,86 m/m\%-nak adódott, illetve TEM mérések alapján a Pd/PDA-nál nagyobb, $5-8 \mathrm{~nm}$ átmérőjű $\mathrm{Pd}$ nanorészecskék keletkeztek rajta. Ennek ellenére, a transzfer hidrogénezésben mutatott katalitikus aktivitása közel megegyezett a Pd/PDA katalizátoréval, így 5 újrahasznosítási ciklusban is $\mathbf{1}$ teljes konverzióját figyeltük meg (24. ábra, a). Az öt reakcióban használt katalizátor ICP-MS és TEM analíziséből kiderült, hogy a katalizátor Pd tartalma csupán 1,55 m/m\%-ra csökkent, míg a nanorészecskék morfológiája jelentősen nem változott. Ezzel ellentétben, egyszeri használat után TEM-el vizsgálva a Pd/PDA katalizátort, a kezdeti 1 - 3 nm-es Pd nanorészecskék enyhe aggregációját figyeltük meg (25. ábra). XPS alapján megállapítottuk, hogy a használt Pd/PDA felületén jelentősen megnőtt, kb. $65 \%$-ra, a $\operatorname{Pd}(0)$ mennyisége a kezdeti $\mathrm{PdO}_{2}$ dús katalizátorfelülethez képest (19. ábra). 
Mindezek tükrében kíváncsiak lettünk a két katalizátor aktivitásában megmutatkozó különbségekre, ezért az optimalizált körülmények között mindkét katalizátor esetén 10 percenkénti mintavétellel folyamatosan követtük 1 redukcióját, megegyező Pd koncentráció mellett $(0,57 \mathrm{~mol} \%)$. A 24 . ábra $b$ részén látható, hogy a Pd/PDA/MNP kezdetben magasabb konverziót biztosít, aminek okaként azt sejtjük, hogy a Pd/PDA felületén lévő Pd-oxidoknak először redukálódniuk kell $\operatorname{Pd}(0)$ formává, hogy elindulhasson 1 redukciója. Miután ez megtörtént, mindkét katalizátorral 40 - 45 perc alatt közel teljes konverzió érhető el.
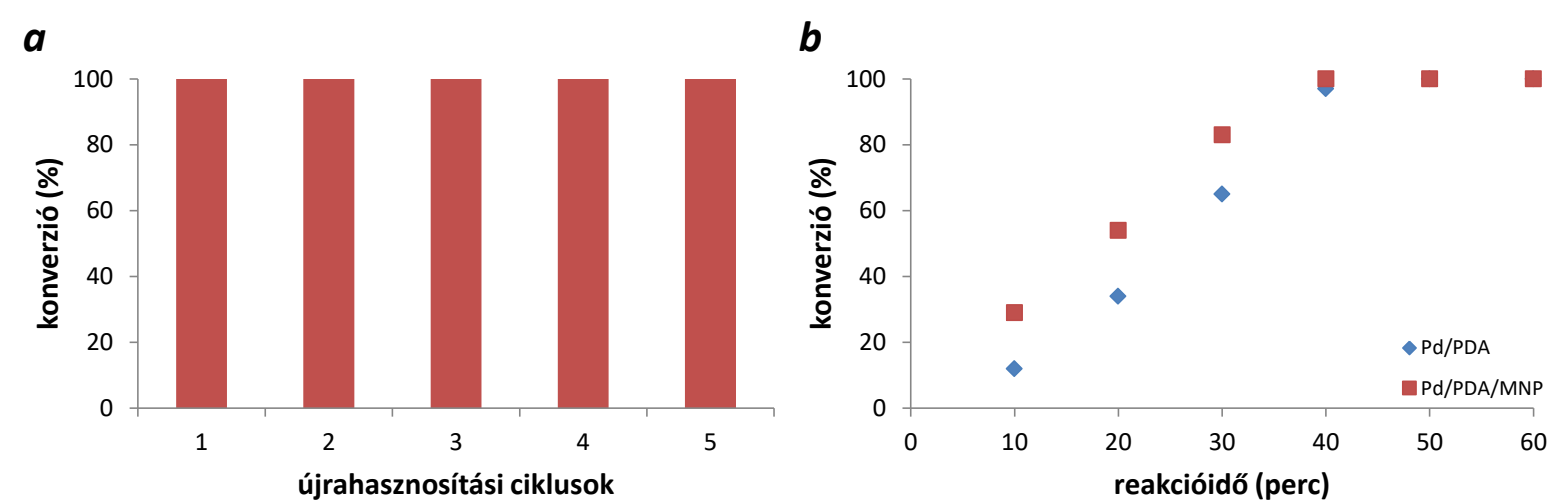

24. ábra (a) $\mathrm{Pd} / \mathrm{PDA} / \mathrm{MNP}$ újrahasznosítása 1 transzfer hidrogénezésében, (b) 1 konverziójának változása a reakcióidő függvényében Pd/PDA és Pd/PDA/MNP katalizátor használata esetén.
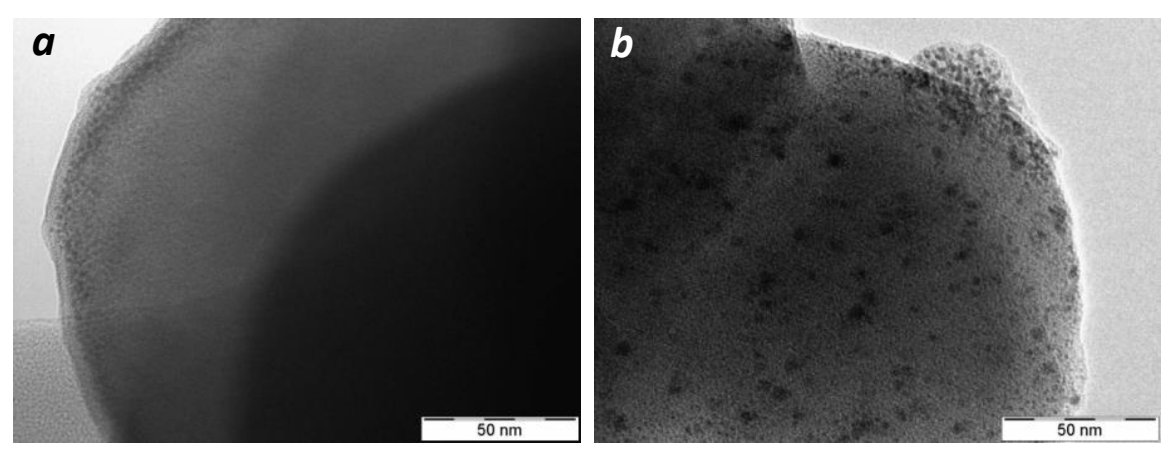

25. ábra Pd/PDA TEM képe $(a)$ használat előtt, és $(b)$ transzfer hidrogénezés után. A reakció során a Pd nanorészecskék enyhe aggregációja következett be.

A transzfer hidrogénezés heterogén jellegének alátámasztásaként 15 perc reakcióidő után forrón szürtük a reakcióelegyet, eltávolítva ezzel a katalizátort, majd $85^{\circ} \mathrm{C}$-on további 45 percig kevertettük. 1 konverziója a szürés előtti 22 \%-ról elhanyagolható mértékben, 24 \%-ra emelkedett a 60. percre. Ez a megfigyelés, és az újrahasznosítás során megfigyelt alacsony fokú fémveszteség alapján úgy véljük, hogy egyrészt a redukció a hordozón rögzített Pd 
nanorészecskék felületén játszódik le, másrészt az adott körülmények között igen jelentős stabilitást biztosít a PDA hordozó a Pd nanorészecskék számára.

Egy milligrammos méretekben jól müködő reakciót méretnövelhetősége alkalmassá tehet akár mindennapi laboratóriumi vagy ipari szintézisek során történő felhasználásra is. Ezért megkíséreltük 1 g tömegü 1 redukcióját az optimalizált körülmények között. Habár 3 óra kellett a teljes konverzióhoz, 744 mg (88 \% kitermelés) benzokaint sikerült izolálnunk a termékelegy feldolgozása után.

\subsubsection{Heck reakció}

A katalitikus C-C kapcsolási reakciók egyik legösszetettebb, és ezért széleskörűen vizsgált átalakítása a Heck reakció, így mi is kíváncsiak voltunk a Pd/PDA katalizátorunk Heck reakcióban való alkalmazhatóságára. Előzetes tapasztalataink alapján ${ }^{[147]}$ bázisként $\mathrm{Na}_{2} \mathrm{CO}_{3}$-ot választva, tetrabutil-ammónium-klorid (TBAC) jelenlétében, N-metil-2-pirrolidon (NMP) oldószerben, $85^{\circ} \mathrm{C}$-on vizsgáltuk különböző aril-halogenidek reakcióját etil-akriláttal (26. ábra, 24). Várakozásainknak megfelelően magas hozamokat értünk el para helyzetben elektronszívó csoportokat tartalmazó aril-bromidokkal (26. ábra, 25 - 27), míg para helyzetben elektronküldő csoporttal rendelkező aril-halogenideknél alacsonyabb termelést tapasztaltunk (26. ábra, 28). Bróm helyett, kapcsolási reakciókban reaktívabb, jód szubsztituenst használva távozó csoportként, a 4-jód-anizol esetében jelentősen nagyobb, $28 \%$ helyett $74 \%$ kitermelést értünk el, a 4-bróm-anizolhoz képest.
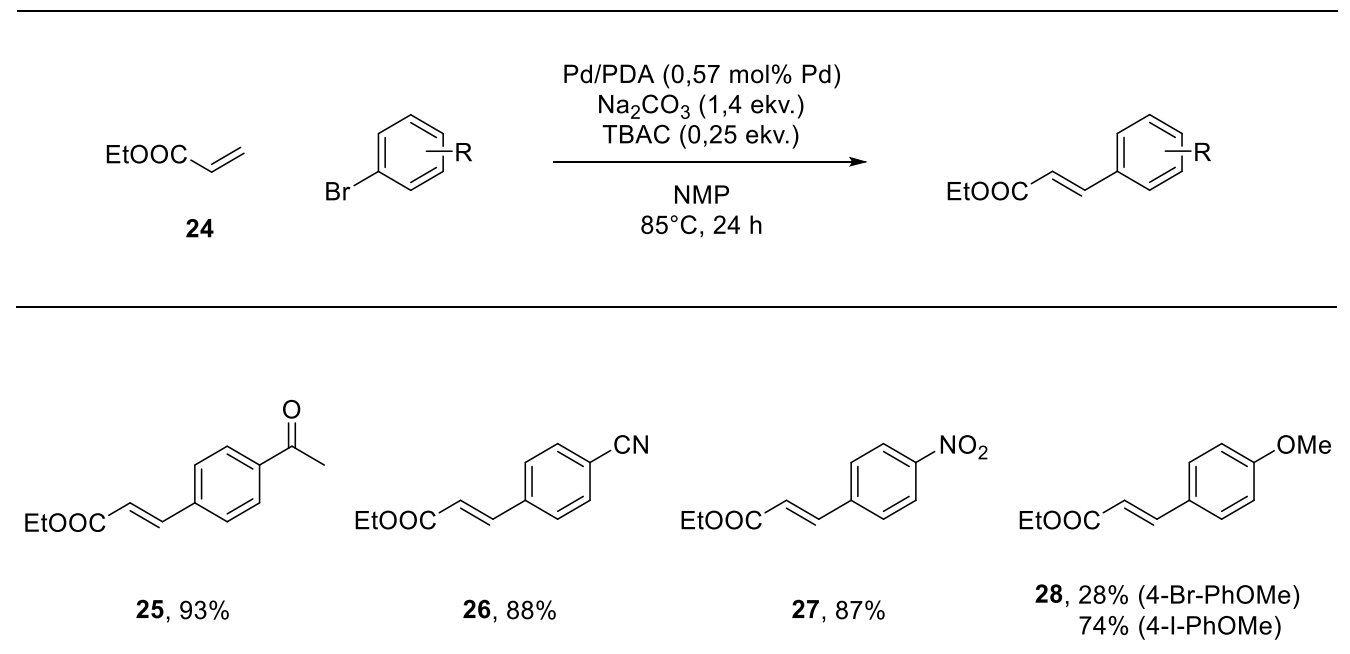

26. ábra Etil-akrilát és aril-halogenidek $\mathrm{Pd} / \mathrm{PDA}$ által katalizált Heck reakciója. Általános reakciókörülmények: Pd/PDA (10 mg, 0,57 mol\% Pd), aril-halogenid (0,5 mmol), etil-akrilát (65 $\mu$, 
0,6 mmol), $\mathrm{Na}_{2} \mathrm{CO}_{3}(74 \mathrm{mg}, 0,7 \mathrm{mmol})$, TBAC (35 mg, 0,125 mmol), NMP (2 ml), 85 ${ }^{\circ} \mathrm{C}, 24 \mathrm{~h} . \mathrm{A}$ feltüntetett értékek izolált hozamok.

Megegyezően a katalitikus transzfer hidrogénezésnél tapasztaltakkal, Heck reakcióban sem tapasztaltunk aktivitásbeli különbséget Pd/PDA/MNP katalizátor használatakor 4-brómacetofenon esetén. Azonban, az újrahasznosított katalizátorral ugyanolyan körülmények között végrehajtott reakció során nem tapasztaltuk termék megjelenését. Ezt a Pd hordozóról történő leoldódásának tulajdonítottuk, amit ICP-MS mérés is alátámasztott. A kezdeti 3,53 $\mathrm{m} / \mathrm{m} \%$ Pd tartalom egy reakció után $0,50 \mathrm{~m} / \mathrm{m} \%$-ra csökkent. Tovább erősítette sejtésünket a reakcióelegy 2 óra reakcióidő utáni forrón szürése, ami további 22 óra után, szilárd katalizátor jelenléte nélkül, jelentős konverziónövekedést mutatott, a 2 óránál mért 27 \%-ról 85 \%-ra.

Ezzel szemben a Pd/PDA katalizátor aktivitásának köszönhetően eredményes méretnövelést hajtottunk végre 1 g 4-bróm-acetofenon etil-akriláttal való kapcsolási reakciójában. 24 óra elteltével $81 \%$ izolált hozamot értünk el.

\subsubsection{Suzuki reakció}

A gyógyszeripartól a szerves elektronikáig széles körben kiemelt fontosságú bifenilek szintézisére a legelterjedtebb eljárás kétséget kizáróan a Pd-katalizált Suzuki reakció. Így Pd/PDA katalizátorunk aktivitását Suzuki reakcióban is megvizsgáltuk. Modellreakcióként fenilboronsav (29) 1-bróm-4-nitrobenzollal (30) történő kapcsolását választva, először optimális reakciókörülményeket kerestünk (2. táblázat). Alkohol típusú oldószerekben (EtOH, $\mathrm{MeOH}, i \mathrm{PrOH})$ gyorsan, 10 percen belül, magas konverziókat értünk el $80^{\circ} \mathrm{C}$-on, szelektíven 4-nitro-bifenil (31) keletkezett (2. táblázat, 1 - 5. sor). Érdemes kiemelni, hogy az iparilag könnyebben, olcsóbban előállítható $96 \mathrm{~V} / \mathrm{V} \%$-os EtOH ugyan olyan jó oldószernek bizonyult, mint a vízmentes EtOH (2. táblázat, 1, 2. sor). Azonban tovább növelve a víztartalmat 50 V/V\%-ra, a hozam $41 \%$-ra csökkent, továbbá a szelektivitás is $65 \%$-ra esett bifenil és fenol melléktermékek megjelenése miatt (2. táblázat, 3. sor). Vízben végezve a reakciót mindössze $12 \% 31$ megjelenését tapasztaltuk (2. táblázat, 6. sor). Aceton, EtOAc, THF, és toluol hasonló, 33 - 40 \% közötti hozamokat biztosított (2. táblázat, 7 - 10. sor). 

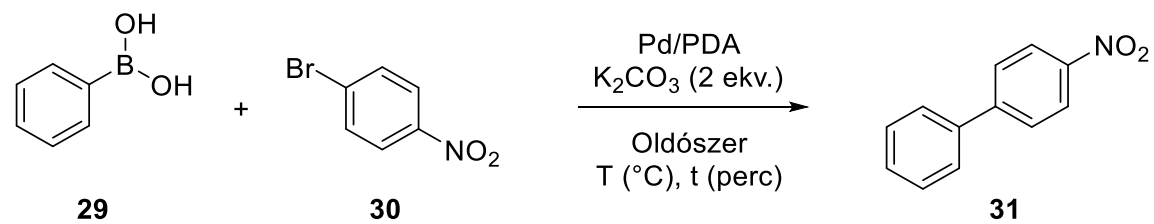

31

\begin{tabular}{cccccc}
\hline Sor & Oldószer & Pd (mol\%) & T $\left({ }^{\circ} \mathbf{C}\right)$ & t (perc) & $\begin{array}{c}\text { Konverzió } \\
(\%)^{b}\end{array}$ \\
\hline 1 & EtOH (abs.) & 0,62 & 80 & 10 & $>99$ \\
2 & EtOH (96 V/V\%) & 0,62 & 80 & 10 & $>99$ \\
3 & EtOH/víz (1:1) & 0,62 & 80 & 10 & $41^{c}$ \\
4 & MeOH & 0,62 & 80 & 10 & 99 \\
5 & $i$ PrOH & 0,62 & 80 & 10 & 85 \\
6 & víz & 0,62 & 80 & 10 & 12 \\
7 & aceton & 0,62 & 80 & 10 & 39 \\
8 & EtOAc & 0,62 & 80 & 10 & 40 \\
9 & THF & 0,62 & 80 & 10 & 39 \\
10 & toluol & 0,62 & 80 & 10 & 33 \\
11 & EtOH (abs.) & 0,62 & 80 & 5 & $>99$ \\
12 & EtOH (96 V/V\%) & 0,62 & 80 & 5 & $>99$ \\
13 & EtOH (96 V/V\%) & 0,31 & 80 & 5 & $>99$ \\
14 & EtOH (96 V/V\%) & 0,031 & 80 & 5 & $>99$ \\
15 & EtOH (96 V/V\%) & 0,031 & 25 & 120 & 99 \\
$16^{d}$ & EtOH (96 V/V\%) & 0,62 & 25 & 120 & 54 \\
$17^{d}$ & EtOH (96 V/V\%) & 0,62 & 80 & 5 & 93 \\
$18^{e}$ & EtOH (96 V/V\%) & 0,62 & 80 & 30 & 13 \\
$19^{e f f}$ & EtOH (96 V/V\%) & 0,62 & 80 & 30 & 58 \\
\hline
\end{tabular}

a Általános reakciókörülmények: 1-bróm-4-nitrobenzol $(0,50 \mathrm{mmol})$, fenilboronsav $(0,55 \mathrm{mmol})$, $\mathrm{K}_{2} \mathrm{CO}_{3}(1,0 \mathrm{mmol}), \mathrm{Pd} / \mathrm{PDA}$, oldószer $(2 \mathrm{ml}) .{ }^{b}$ GC-MS-el meghatározva. ${ }^{c} 65 \%$ szelektivitás mellett fenol és bifenil melléktermék megjelenését tapasztaltuk. ${ }^{d}$ Katalizátorként Pd/C-t használva. ${ }^{e} 1-k l o ́ r-4-$ nitrobenzolt használva reaktánsként. ${ }^{f} 1$ ekv. TBAC adalékanyagot hozzáadva.

Csökkentve a reakcióidőt 5 percre, még mindig nem volt tapasztalható különbség absz. és 96 V/V\%-os EtOH-ban végzett reakció között (2. táblázat, 11, 12. sor), ezért a további vizsgálatokat $96 \mathrm{~V} / \mathrm{V} \%$-os EtOH-ban végeztük. A katalizátor mennyiségét a kezdetben alkalmazott $10 \mathrm{mg}(0,62 \mathrm{~mol} \%$ Pd) felére, majd utóbbi tizedére (0,5 mg Pd/PDA; 0,031 mol\% Pd) csökkentve sem tapasztaltunk változást, teljes konverzió mellett szelektíven 31 keletkezett $80^{\circ} \mathrm{C}$-on (2. táblázat, 13, 14. sor), ezért a hömérséklet csökkentése mellett döntöttünk. Szobahőmérsékleten, 0,031 mol\% katalizátormennyiség mellett is, magas, $99 \%$ konverziót értünk el 2 óra elteltével (2. táblázat, 15. sor). Összehasonlításképpen, $\mathrm{Pd} / \mathrm{C}$-t használva katalizátorként szükséges volt $0,62 \mathrm{~mol} \%$ Pd-t juttatnunk a reakcióelegybe, hogy a Pd/PDA- 
hoz hasonló katalitikus aktivitást kapjunk, viszont szobahőmérsékleten, 2 óra alatt így is csak $54 \%$ hozamot értünk el (2. táblázat, 16 . sor). $\mathrm{Pd} / \mathrm{C}$ használata mellett, $80^{\circ} \mathrm{C}$-ra emelve a hőmérsékletet már 5 perc alatt $93 \%$-ra emelkedett a hozam (2. táblázat, 17. sor), igaz, a Pd/PDA-hoz képest tízszeres Pd mennyiség kellett $80^{\circ} \mathrm{C}$-on is, valószínűleg a csökkent reaktivitással társuló nagyobb Pd részecskeméret miatt. Fontos kiemelnünk, hogy $\mathbf{3 0}$ helyett 1-klór-4-nitrobenzolt használva $13 \%$-ban jelent meg a kapcsolt termék a termékelegyben, viszont 1 ekv. TBAC hozzáadása esetén $58 \%$ konverziót értünk el 30 perc alatt, ami nem változott a reakcióidő meghosszabbításával (2. táblázat, 18, 19. sor). A kvaterner ammóniumsók szerepe C-C kapcsolási reakciókban sokrétü. ${ }^{[147]}$ Jelen esetben a Pd nanorészecskék leoldódását segíthette a hordozóról, azonban sejtéseink szerint ezután nanorészecske aggregáció következhetett be, ami katalitikusan inaktív Pd-korom megjelenésével járt.

A fenti eredmények tükrében további vizsgálatainkat a 2. táblázat, 15. sorában feltüntetett körülmények között végeztük, kivételt képez ez alól a reakcióidő, amit 3 órára növeltünk, ugyanis több szubsztrát esetén még nem volt teljes a konverzió 2 óra elteltével. Fontos kiemelnünk, hogy inert atmoszférát egyik esetben sem használtunk, ettől függetlenül magas termékszelektivitásokat tapasztaltunk, csupán $<1,5 \%$ bifenil melléktermék megjelenését detektáltuk néhány esetben. A szubsztituensek pozíciójának hatását vizsgálva orto-, meta-, és para-bróm-nitrobenzolt reagáltattunk fenilboronsavval (27. ábra, 31 - 33). Orto szubsztituens esetén jelentősen esett a kitermelés, viszont a meta helyzetű szubsztituens már csak elhanyagolható mértékben gátolta a reakciót. A megfigyelt sztérikus gátlást valószínüleg Pd orto-szubsztituált aril-halogenidre történő oxidatív addíciója során, a hordozó felülettel történő valamilyen interakciójának köszönhetjük. Para helyzetü elektronküldő szubsztituensek (27. ábra, 34, 35) enyhén csökkentették a kitermelést (54 \%, 69\%), azonban 4-bróm-acetofenon esetén is hasonló hozamot figyeltünk meg (27. ábra, 36). Szubsztituált fenilboronsavakat használva magas konverziókat és izolált hozamokat értünk el (27. ábra, 37 - 39). Fontos eredmény, hogy a szakirodalomban problémás eseteknek jegyzett heteroaromás vegyületekkel végzett Suzuki reakciókban ${ }^{[148]}$ is magas hozamokat értünk el, azonban ehhez növelnünk kellett az alkalmazott hőmérsékletet $80^{\circ} \mathrm{C}$-ra (27. ábra, $\mathbf{4 0}-\mathbf{4 3}$ ). 


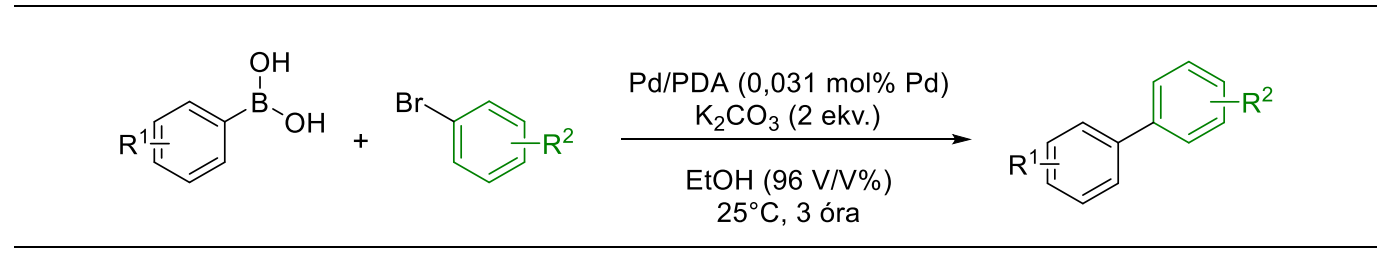<smiles>O=[N+]([O-])c1ccc(-c2ccccc2)cc1</smiles>

$31,93 \%$<smiles>COc1ccc(-c2ccccc2)cc1</smiles>

34, $54 \%$<smiles>O=[N+]([O-])c1ccc(-c2cccc([N+](=O)[O-])c2)cc1</smiles>

$37,87 \%$<smiles>O=[N+]([O-])c1ccccc1-c1ccccc1</smiles>

32, $11 \%^{a}$<smiles>Nc1ccc(-c2ccccc2)cc1</smiles>

$35,69 \%$<smiles>O=[N+]([O-])c1ccc(-c2cc(C(F)(F)F)cc(C(F)(F)F)c2)cc1</smiles>

$38,88 \%$<smiles>O=[N+]([O-])c1cccc(-c2ccccc2)c1</smiles>

33, $85 \%$<smiles>CC(=O)c1ccc(-c2ccccc2)cc1</smiles>

36, $65 \%$<smiles>Cc1cc(-c2ccc([N+](=O)[O-])cc2)ccc1F</smiles>

$39,76 \%$<smiles>FC(F)(F)c1cc(-c2cccnc2)cc(C(F)(F)F)c1</smiles>

$40,68 \%^{\mathrm{b}}$<smiles>FC(F)(F)c1cc(-c2cccc3[nH]ccc23)cc(C(F)(F)F)c1</smiles>

$41,57 \%^{b}$<smiles>FC(F)(F)c1cc(-c2ccc3[nH]ccc3c2)cc(C(F)(F)F)c1</smiles>

$42,65 \%^{b}$<smiles>FC(F)(F)c1cc(-c2ccc3ccccc3n2)cc(C(F)(F)F)c1</smiles>

43, $76 \%^{\mathrm{b}}$

27. ábra Alacsony Pd mennyiséget igénylő Suzuki reakciók termékei. Általános reakciókörülmények: $\mathrm{Pd} / \mathrm{PDA}\left(0,5 \mathrm{mg}\right.$; 0,031 mol\% Pd), aril-halogenid (0,5 mmol), aril-boronsav (0,55 mmol), $\mathrm{K}_{2} \mathrm{CO}_{3}(1,0$ mmol), EtOH $96 \mathrm{~V} / \mathrm{V} \%(2 \mathrm{ml}), 25^{\circ} \mathrm{C}, 3$ óra. A feltüntetett értékek izolált hozamok. ${ }^{a}$ Kitermelés GCMS-el megállapítva. ${ }^{b}$ Reakciók $80^{\circ} \mathrm{C}$-on végezve 1 órán át.

Megvizsgáltuk 29 és 30 Suzuki reakciójának méretnövelhetőségét. Az irodalomban fellelhető extrém alacsony Pd koncentrációval végzett Suzuki reakciók ${ }^{[58,149]}$ által ösztönözve úgy döntöttünk, hogy az alkalmazott Pd/PDA katalizátor mennyiségét amennyire lehetséges, lecsökkentjük. Így 2 g 30, 1,1 ekvivalens 29-el történő reakciójában mindössze 18 ppm Pd 
$\left(1,8 \times 10^{-3} \mathrm{~mol} \%\right)$ jelenlétében $80^{\circ} \mathrm{C}$-on 30 perc elteltével már teljes konverziót figyeltünk meg. A termékelegy feldolgozását követően $92 \%$ izolált hozamot értünk el.

Két különböző hőmérsékleten végeztünk katalizátorszürési tesztet, hogy megvizsgáljuk a Suzuki reakció során bekövetkező Pd leoldódás mértékét a hordozóról. Mivel a szürést 10 és $50 \%$ konverzió között érdemes végezni, ezért a megfelelő szürési időpont kiválasztásához 15 percenkénti mintavételezéssel követtük 29 és 30 Suzuki reakcióját szobahőmérsékleten, 2 órán keresztül (28. ábra). A tesztreakciót $0,5 \mathrm{mg}$ és $10 \mathrm{mg} \mathrm{Pd} / \mathrm{PDA}$ katalizátorral is elvégeztük.

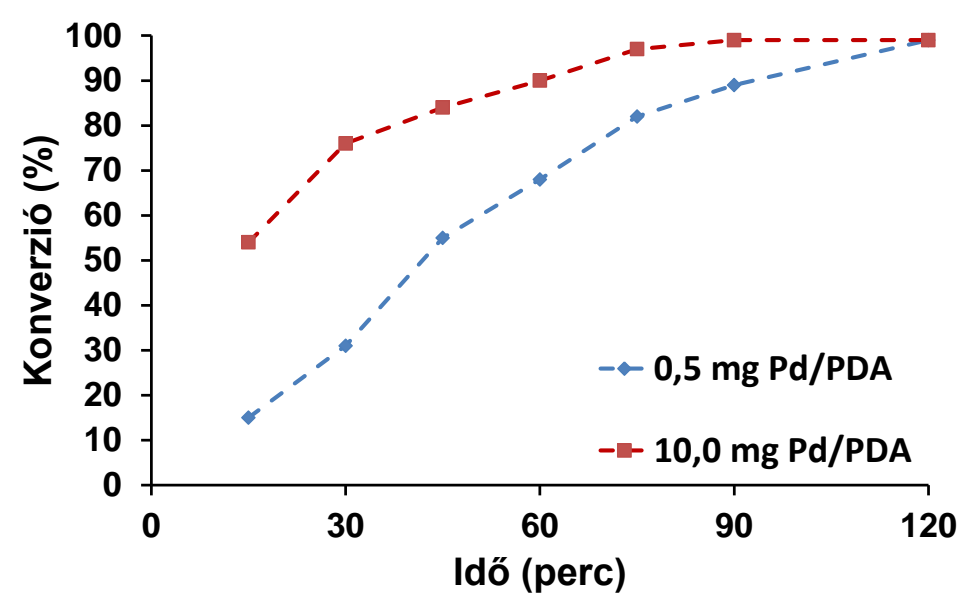

28. ábra Konverzió változása a reakcióidő függvényében 29 és 30 szobahőmérsékleten végzett Suzuki reakciójában $0,5 \mathrm{mg}$ és $10,0 \mathrm{mg}$ Pd/PDA katalizátor jelenlétében.

Az eredmények alapján, katalizátorszürési tesztjeinkben a reakció indításától számolt 15. percben távolítottuk el a katalizátort a reakcióelegyekből, majd további 60 percen át kevertettük a szürleteket. A katalizátor mennyiségétől függetlenül jelentős konverziónövekedést tapasztaltunk, ami oldatfázisban jelenlévő katalitikusan aktív Pd részecskékre utalt (3. táblázat, 1, 2, és 5, 6. sorok). A szürési tesztet $80^{\circ} \mathrm{C}$-on is megismételtük, ám ekkor 5 perc elteltével (teljes konverzió) távolítottuk el a szilárd katalizátort, majd a szürletet „oldószerként” használva további reaktánsokat adva az elegyhez, dodekán belső sztenderd mellett, további 10 percig kevertettük az elegyet $80^{\circ} \mathrm{C}$-on (3. táblázat, 3, 4, és 7, 8. sorok). Összehasonlítva a homogén oldatok katalitikus aktivitását elmondhatjuk, hogy szobahőmérsékleten végezve a reakciót, 15 perc utáni szüréssel, a szürlet lényegesen aktívabbnak bizonyult, mint $80^{\circ} \mathrm{C}$-on 5 perc után. Ezek alapján úgy gondoljuk, hogy a leoldódás inkább idő, mint hőmérsékletfüggő, valamint a leoldódott Pd részecskéknek 
jelentős szerepe van a Suzuki reakcióban, ellentétben a katalitikus transzfer hidrogénezésnél tapasztaltakkal.

3. táblázat Suzuki reakciók során végzett szürési tesztek eredményei ${ }^{a}$

\begin{tabular}{ccccc} 
Sor & $\begin{array}{c}\text { Pd/PDA } \\
(\mathrm{mg})\end{array}$ & Hömérséklet $\left({ }^{\circ} \mathrm{C}\right)$ & $\begin{array}{c}\text { Idő } \\
(\text { perc })\end{array}$ & $\begin{array}{c}\text { Konverzió } \\
(\%)^{b}\end{array}$ \\
\hline 1 & 0,5 & 25 & 15 & 14 \\
2 & 0,5 & 25 & 60 & 81 \\
3 & 0,5 & 80 & 5 & $>99$ \\
4 & 0,5 & 80 & 10 & 35 \\
5 & 10,0 & 25 & 15 & 63 \\
6 & 10,0 & 25 & 60 & 99 \\
7 & 10,0 & 80 & 5 & $>99$ \\
8 & 10,0 & 80 & 10 & 51 \\
\hline
\end{tabular}

a Általános reakciókörülmények: 1-bróm-4-nitrobenzol $(0,5 \mathrm{mmol})$, fenilboronsav $(0,55 \mathrm{mmol})$, $\mathrm{K}_{2} \mathrm{CO}_{3}(1,0 \mathrm{mmol}), \mathrm{Pd} / \mathrm{PDA}$, EtOH 96V/V\% (2 ml). ${ }^{b}$ A konverziók GC-MS-el lettek meghatározva.

Az újrahasznosíthatóság vizsgálatához a Pd/PDA/MNP katalizátorunkat használtuk, ennek aktivitása azonban már észrevehetően különbözött a Pd/PDA Suzuki reakcióban mutatott aktivitásától (4. táblázat). Magyarázatul szolgálhat a szakirodalomban fellelhető Pd részecskeméret - aktivitás összefüggés, ${ }^{[150]}$ ugyanis az $1-3 \mathrm{~nm}$ átmérőjű Pd nanorészecskéket tartalmazó Pd/PDA-val ellentétben a Pd/PDA/MNP-n $5-8$ nm-es Pd részecskék találhatók. Hogy a méret - aktivitás összefüggést bizonyítsuk, előállítottunk egy, a szakirodalomban leírt recept alapján ${ }^{[66]} 10$ - 20 nm közötti, átlagban 13 nm-es Pd részecskéket tartalmazó Pd/PDA katalizátort (Pd/PDA-13, 29. ábra). Összehasonlítva a három katalizátor aktivitását, megegyező Pd koncentrációt használva 29 és 30 Suzuki reakciójában alkalmaztuk őket (4. táblázat). Mindhárom katalizátor szelektíven a várt terméket eredményezte, azonban várakozásainknak megfelelően a nagyobb Pd részecskeméret valóban kisebb aktivitást eredményezett. Míg 60 perc reakcióidő alatt a Pd/PDA 90 \% konverziót biztosított, addig a Pd/PDA/MNP ennek alig több mint felét eredményezte. A legnagyobb Pd részecskemérettel rendelkező Pd/PDA-13 további $8 \%$-al alacsonyabb konverziót adott. 

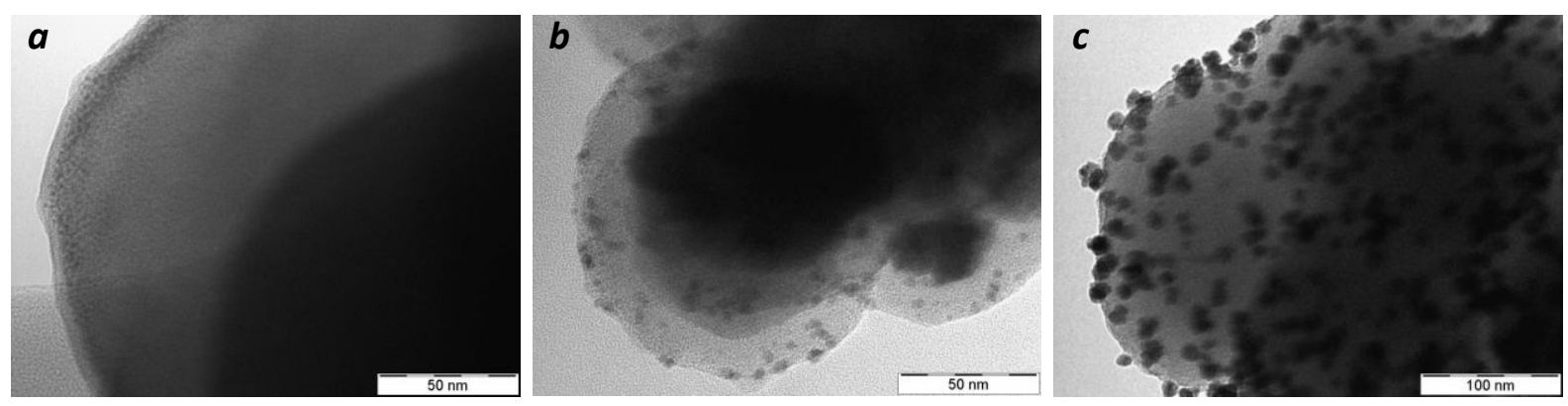

29. ábra A Pd részecskeméret - aktivitás összefüggés vizsgálatában felhasznált katalizátorok TEM képe. (a) Pd/PDA, (b) Pd/PDA/MNP, (c) Pd/PDA-13.

4. táblázat PDA-on rögzített Pd katalizátorok aktivitása 29 és 30 Suzuki reakciójában. ${ }^{a}$

\begin{tabular}{cccc}
\hline Sor & Katalizátor & $\begin{array}{c}\text { Pd átmérő } \\
(\mathrm{nm})\end{array}$ & $\begin{array}{c}\text { Konverzió } \\
(\%)^{b}\end{array}$ \\
\hline 1 & Pd/PDA & $1-3$ & 90 \\
2 & Pd/PDA/MNP & $5-8$ & 50 \\
3 & Pd/PDA-13 & $10-20$ & 42 \\
\hline
\end{tabular}

${ }^{a}$ Reakciókörülmények: 1-bróm-4-nitrobenzol $(0,5 \mathrm{mmol})$, fenilboronsav $(0,55 \mathrm{mmol}), \mathrm{K}_{2} \mathrm{CO}_{3}(1,0$ mmol), „Pd” (0,031 mol\%), EtOH 96V/V\% $(2 \mathrm{ml}), 25^{\circ} \mathrm{C}, 60$ perc. ${ }^{b}$ A konverziók GC-MS-el lettek meghatározva.

A részecskemérettől függetlenül a $\mathrm{Pd} / \mathrm{PDA} / \mathrm{MNP} 80^{\circ} \mathrm{C}$-on csak három használatot követően mutatott csökkenő konverziót 29 és 30 Suzuki reakciójában, így az 5. és 6. körben 5-ről 15 percre növeltük a reakcióidőt, ami így elfogadható, 60 \% feletti konverzióig vitte a reakciót (30. ábra). Az újrahasznosított katalizátor ICP-MS analízise jelentős, a kezdeti 3,53 m/m\%-ról 2,36 m/m\%-ra történő Pd tartalom csökkenést mutatott 6 kör után. Amennyiben az újrahasznosítást szobahőmérsékleten, 2 órás ciklusokban végeztük, a konverzió esését már a 3. körben detektáltuk, és közel teljes aktivitásvesztést tapasztaltunk a 4. kör során. Az 5. kör után mindössze $1,85 \mathrm{~m} / \mathrm{m} \%$ Pd koncentrációt mértünk ICP-MS-el a katalizátoron, ami kevesebb a 6 kör $80^{\circ} \mathrm{C}$-os reakció után mért 2,36 \%-nál. Ezek, és a szürési tesztek során kapott eredmények alapján arra következtettünk, hogy a reakcióidő változtatása nagyobb hatással van a Pd leoldódására a PDA hordozóról, mint az emelt hőmérséklet. Megjegyzendő, hogy a leoldódás mellett jelentős $\mathrm{Pd}$ aggregáció is megfigyelhető az újrahasznosított Pd/PDA/MNP-ről készült TEM felvételeken, az eredeti méret duplája, 8 - 15 nm átmérőjü Pd részecskék jelentek meg a $80^{\circ} \mathrm{C}$-on végzett újrahasznosítás 6 . köre után. 


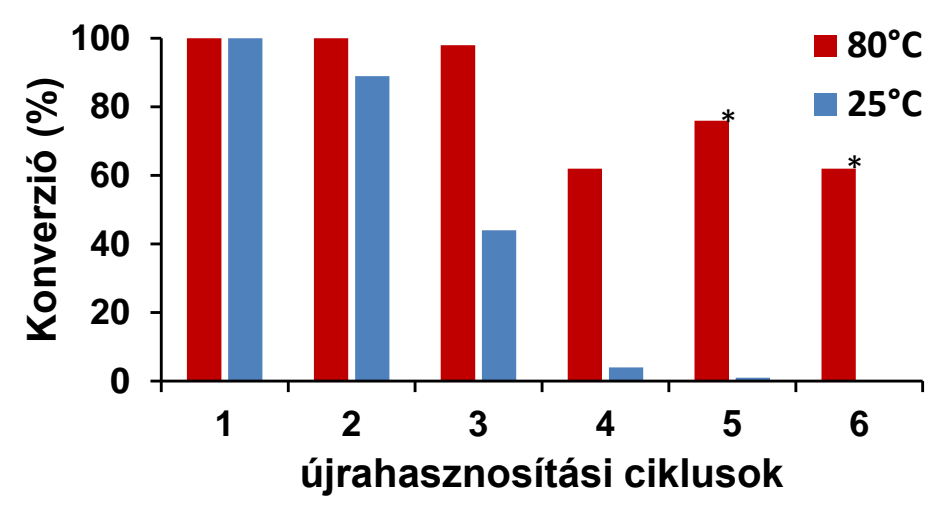

30. ábra Pd/PDA/MNP újrahasznosítása Suzuki reakcióban 80 és $25^{\circ} \mathrm{C}$-on. Reakciókörülmények: 1bróm-4-nitrobenzol (0,5 mmol), fenilboronsav (0,55 mmol), $\mathrm{K}_{2} \mathrm{CO}_{3}(1,0 \mathrm{mmol}), \mathrm{Pd} / \mathrm{PDA} / \mathrm{MNP}(0,031$ mol\% Pd), EtOH 96V/V\% (2 ml), $80^{\circ} \mathrm{C}, 5$ perc, vagy $25^{\circ} \mathrm{C}, 2$ h. (*) Reakcióidő: 15 perc.

\subsubsection{Tandem Suzuki reakció/katalitikus transzfer hidrogénezés}

A Pd/PDA katalizátor Suzuki reakcióban mutatott kiemelkedő aktivitása, és a transzfer hidrogénezésben való széleskörü alkalmazhatósága arra ösztönzött minket, hogy kapcsoljuk össze a két folyamatot egy úgynevezett tandem rendszerré, így egyedényben, egy katalizátorral, egy időben, ugyanazon körülmények között hajtsuk végre a C-C kapcsolást és a nitroredukciót. Mindkét reakcióban használható oldószernek bizonyult az EtOH, valamint nitroredukcióban hatékony hidrogénforrás volt a HCOONa. Mivel transzfer hidrogénezésben aril-halogenidek halogénvesztését figyeltük meg, ezért szükségesnek tünt, hogy a Suzuki reakció gyorsan, a redukció előtt végbemenjen. Ez megtörtént a Suzuki reakcióban modell rendszernek választott 29 és 30 reakciója esetén (31. ábra), amely tandem reakciójához a katalitikus transzfer hidrogénezésekben alkalmazotthoz hasonló katalizátormennyiség (10 mg Pd/PDA, 0,62 mol\% Pd), azonos mennyiségü HCOONa (4 ekv., 2,0 mmol), valamint a Suzuki reakcióban használt $\mathrm{K}_{2} \mathrm{CO}_{3}$ bázis ( 2 ekv., 1,0 mmol) jelenlétében 30 perc után teljes konverziót tapasztaltunk.

A modell rendszerhez hasonlóan, a reaktánsok nagy részénél $80^{\circ} \mathrm{C}$-on percek alatt teljes konverzióval végbement a C-C kapcsolás, majd 1 órán belül a nitroredukció (31. ábra). Azonban egyes esetekben a Suzuki reakció sebessége összemérhető volt a transzfer hidrogénezésével, így melléktermékek megjelenése mellett az izolált hozam romlását tapasztaltuk. Ennek kiküszöbölése érdekében két, különböző hőmérsékletprogrammal rendelkező módszert dolgoztunk ki (5. táblázat). 

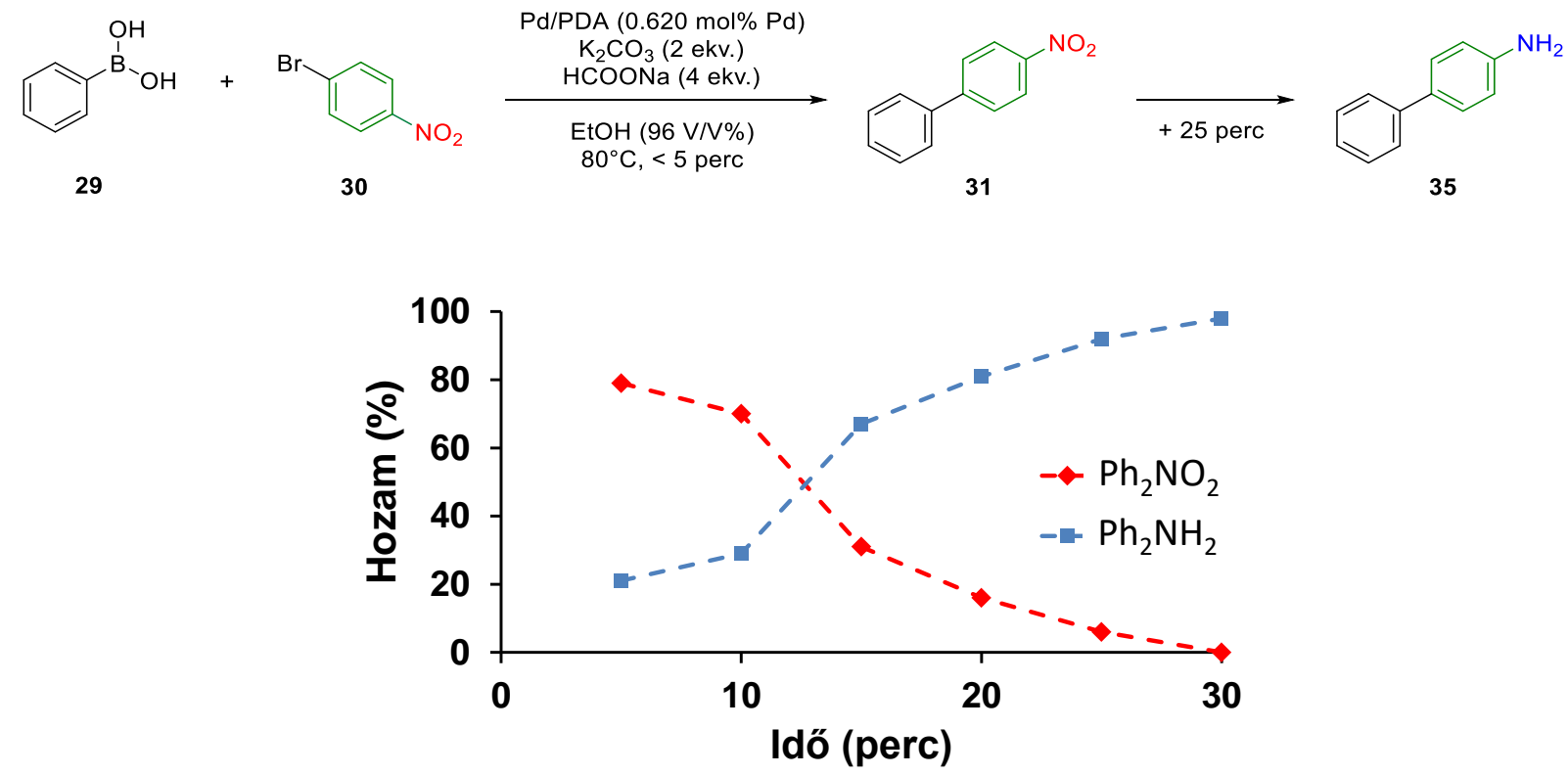

31. ábra 29 és 30 tandem Suzuki reakció/transzfer hidrogénezése során 5 percen belül teljes konverzióval keletkező 4-nitro-bifenil redukciója 4-amino-bifenillé (I. Módszert használva).

A nagyobb reakciósebességü Suzuki reakcióknál alkalmazott I. Módszer esetén 1 órán át $80^{\circ} \mathrm{C}$-on tartottuk az összes reaktánst tartalmazó reakcióelegyet. Amennyiben a Suzuki reakció nem folyt le elég gyorsan, és a redukcióval összemérhető reakciósebességgel zajlott $80^{\circ} \mathrm{C}$-on, úgy a II. Módszert alkalmazva a reakcióelegyet elöször 2 órán át szobahőmérsékleten kevertettük, majd felfütöttük $80^{\circ} \mathrm{C}$-ra, és további 1 órán át folytattuk a kevertetését. Mivel a redukcióhoz szükséges az emelt hőmérséklet, ezért a folyamat első szakaszában csak a Suzuki reakció tudott lejátszódni, elkerülve ezzel a mellékreakciókat. Fontos megjegyeznünk, hogy mindkét módszer esetén, a reakció elindítása előtt minden reaktánst, és a katalizátort is belehelyeztük a reakcióelegybe, és csak a hőmérsékletet változtattuk a szelektivitás növelésének érdekében. Így, a II. Módszernek köszönhetően több esetben is a kitermelés jelentős növekedését tudtuk elérni (32. ábra, 47, 48, 52, 53, 55, 56, 59).

5. Táblázat A tandem Suzuki reakció/transzfer hidrogénezésekben használt körülmények

\begin{tabular}{c|c|c|c}
\hline & I. Módszer & II. Módszer & III. Módszer \\
\hline Reakcióidő & $1 \mathrm{~h}$ & $2 \mathrm{~h}+1 \mathrm{~h}$ & $2 \mathrm{~h}+1 \mathrm{~h}$ \\
\hline Hőmérséklet & $80^{\circ} \mathrm{C}$ & $25^{\circ} \mathrm{C} / 80^{\circ} \mathrm{C}$ & $80^{\circ} \mathrm{C} / 80^{\circ} \mathrm{C}$ \\
\hline $\begin{array}{c}\text { HCOONa reakcióelegybe } \\
\text { juttatása }\end{array}$ & reakció kezdetén & reakció kezdetén & $\begin{array}{c}\text { második lépés } \\
\text { elején }\end{array}$ \\
\hline
\end{tabular}


Aril-boronsavak 1-bróm-4-nitrobenzollal történő reakciói általában magasabb hozamot biztosítottak, mint 1-bróm-3-nitrobenzol esetén (32. ábra, 35, 44-49 vs. 51 - 58), azonban 1bróm-2-nitrobenzolt használva nem kaptunk várt terméket, csak anilin megjelenését tapasztaltuk (32. ábra, 60). Ez a Suzuki reakcióban is megfigyelt orto-helyzetű csoport sztérikus gátlása miatt történhetett. 3-Nitro-fenilboronsav és 1-bróm-3-, valamint -4nitrobenzol tandem reakciója esetén a mindkét reaktánson jelenlévő nitrocsoport redukciójának teljessé tétele érdekében 6 ekvivalens HCOONa használata volt szükséges (32. ábra, 49, 56). Ezzel szemben, a redukálószer mennyiségétől függetlenül, 3-nitro-fenilboronsav helyett 4-nitro-fenilboronsavat alkalmazva a Suzuki reakció lejátszódását nem tapasztaltuk egyik reaktáns esetén sem (32. ábra, 50, 57). A nitrocsoport szelektív redukcióját figyeltük meg 3-nitro-fenilboronsav és 4-bróm-acetofenon tandem reakciójában, a II. Módszernek köszönhetően magas, 70 \% kitermelést elérve (32. ábra, 59). 


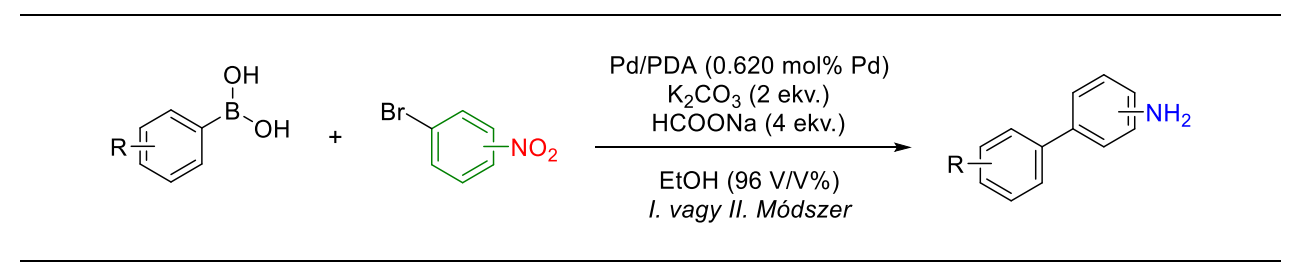

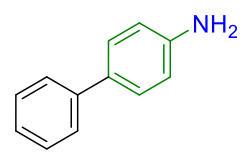

35, $1^{a} .: 92 \%$ $\|^{b} .:$

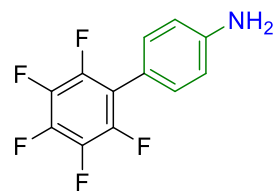

46, n.r. ${ }^{c}$

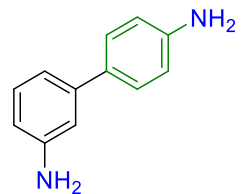

$\mathbf{4 9}^{d}$, I.: $40 \%$

II.: $43 \%$<smiles>Nc1cccc(-c2cc(C(F)(F)F)cc(C(F)(F)F)c2)c1</smiles>

52, I.: $52 \%$

II.: $73 \%$<smiles>COc1ccc(OC)c(-c2cccc(N)c2)c1</smiles>

$55,1: 0 \%$

II.: $38 \%$

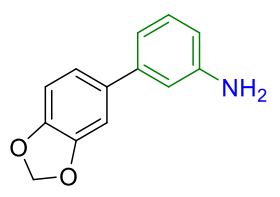

58, I.: $32 \%$<smiles>Nc1ccc(-c2cc(C(F)(F)F)cc(C(F)(F)F)c2)cc1</smiles>

44, I.: $95 \%$

II.: -

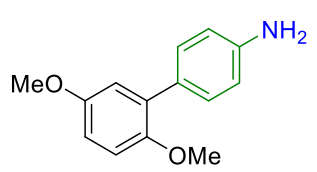

47, I.: $20 \%$

II.: $46 \%$

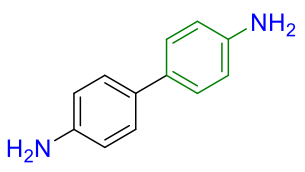

50, n.r. ${ }^{c, d}$

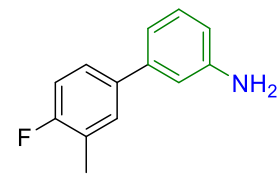

53, I.: $55 \%$

II.: $81 \%$<smiles>Nc1cccc(-c2cccc(N)c2)c1</smiles>

$\mathbf{5 6}^{d}, 1 .: 0 \%$

II.: $45 \%$

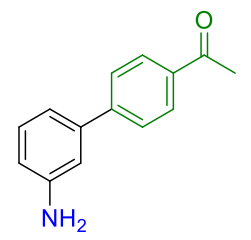

59, I.: $51 \%$

II.: $70 \%$<smiles>Cc1cc(-c2ccc(N)cc2)ccc1F</smiles>

45, I.: $85 \%$

II.: -

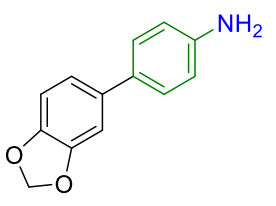

48, I.: $69 \%$

II.: $80 \%$

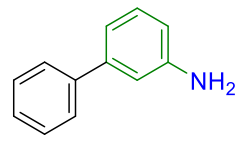

$51,1 .: 93 \%$

$$
\text { II.: - }
$$<smiles>Nc1cccc(-c2c(F)c(F)c(F)c(F)c2F)c1</smiles>

54 , n. r. ${ }^{c}$<smiles>Nc1ccc(-c2cccc(N)c2)cc1</smiles>

57, n. r. ${ }^{c, d}$

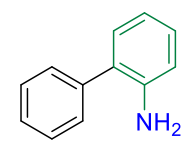

60, n. r. ${ }^{c}$

32. ábra Tandem Suzuki reakció/transzfer hidrogénezés termékei. Általános reakciókörülmények: aril-halogenid (0,50 mmol), aril-boronsav (0,55 mmol), $\mathrm{K}_{2} \mathrm{CO}_{3}(1,0 \mathrm{mmol}), \mathrm{HCOONa}(2,0 \mathrm{mmol})$, 
Pd/PDA (10 mg, 0,620 mol\% Pd), EtOH 96V/V\% (2 ml). A feltüntetett értékek izolált hozamok. ${ }^{a} I$. Módszer: $80^{\circ} \mathrm{C}, 1$ h. ${ }^{b}$ II. Módszer: $25^{\circ} \mathrm{C}, 2 \mathrm{~h}$, majd $80^{\circ} \mathrm{C}, 1 \mathrm{~h} .{ }^{c}$ Anilin keletkezését detektáltuk. ${ }^{d} 3,0$ mmol HCOONa-t használtunk. (n.r. = nincs reakció)

A kevésbé reaktív heteroaril-bromidok esetén módosítanunk kellett módszereinken, hogy csökkentsük a mellékreakciók során bekövetkező reaktánsveszteséget. Elöször is $80^{\circ} \mathrm{C}$ on 2 órán át kevertettük a reakcióelegyet a redukálószer hiányában, így elkerülve a dehalogéneződést, majd a 2 óra letelte után hozzáadtuk a 4 ekvivalens HCOONa-t, és a redukciót további 1 órán át hagytuk lejátszódni (III. Módszer). Habár az átalakulás így már nem tekinthető tandem reakciónak, hanem egyszerü egyedényes, szekvenciális folyamat, de ennek a módosításnak köszönhetően elfogadható mértékü izolált hozamokat értünk el viszonylag rövid reakcióidő (3 óra) alatt (33. ábra).

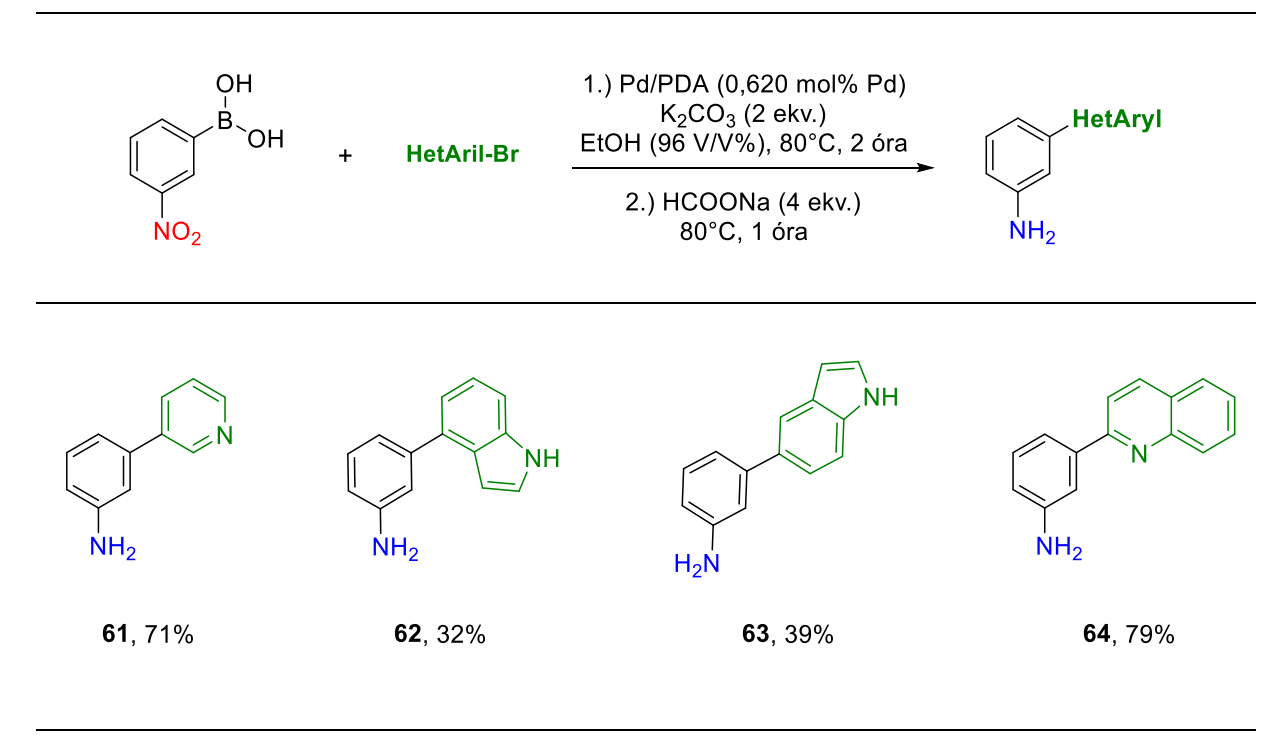

33. ábra Heteroaril-bromidok és 3-nitro-fenilboronsav tandem Suzuki reakció/transzfer hidrogénezésében előállított termékek. Általános reakciókörülmények: heteroaril-halogenid $(0,50$ mmol), aril-boronsav (0,55 mmol), $\mathrm{K}_{2} \mathrm{CO}_{3}(1,0 \mathrm{mmol}), \mathrm{Pd} / \mathrm{PDA}(10 \mathrm{mg}, 0,620 \mathrm{~mol} \% \mathrm{Pd})$, EtOH 96V/V\% $(2 \mathrm{ml}), 80^{\circ} \mathrm{C}, 2 \mathrm{~h}$, majd HCOONa $(2,0 \mathrm{mmol})$ hozzáadása után további $1 \mathrm{~h} 80^{\circ} \mathrm{C}$-on. A feltüntetett értékek izolált hozamok.

A méretnövelhetőség vizsgálatához a fentebb vázolt modell rendszerünket (31. ábra) használtuk az I. Módszer körülményei között. 1 g 29-böl kiindulva 1 óra után teljes konverziót detektáltunk, és $87 \%$ hozammal izoláltuk a kapcsolt, redukált 4-aminobifenil terméket.

Jelentős hátránynak bizonyult az $5-8 \mathrm{~nm}$ Pd részecskeátmérő a $\mathrm{Pd} / \mathrm{PDA} / \mathrm{MNP}$ újrahasznosítása esetén tandem Suzuki reakció/transzfer hidrogénezésben (6. táblázat). A 
katalizátor modell rendszerünkben történő I. Módszer szerinti használatát követően csak 66 \% hozamot detektáltunk, míg a 2. körben már nem értünk el vele konverziót. Érdekes módon, a II. Módszert használva csak a 2. körben csökkent a hozam 61 \%-ra, azonban a 3. körre e módszer mellett is dezaktiválódott a katalizátor.

6. táblázat $\mathrm{Pd} / \mathrm{PDA} / \mathrm{MNP}$ újrahasznosítása 29 és $\mathbf{3 0}$ tandem Suzuki reakció/transzfer hidrogénezés reakciójában.

\begin{tabular}{cccc}
\hline Sor & Módszer $^{a}$ & $\begin{array}{c}\text { Újrahasznosítási }^{\text {ciklus }} \\
\text { Konverzió }(\%)^{b}\end{array}$ & ${ }^{b}$ \\
2 & I. & 1 & 66 \\
3 & I. & 2 & 0 \\
4 & I. & 3 & 0 \\
5 & II. & 1 & 84 \\
6 & II. & 2 & 61 \\
\hline
\end{tabular}

Általános reakciókörülmények: 1-bróm-4-nitrobenzol $(0,50 \mathrm{mmol})$, fenilboronsav $(0,55 \mathrm{mmol})$, $\mathrm{K}_{2} \mathrm{CO}_{3}(1,0 \mathrm{mmol}), \mathrm{HCOONa}(2,0 \mathrm{mmol}), \mathrm{Pd} / \mathrm{PDA} / \mathrm{MNP}$ (0,620 mol\% Pd), EtOH 96V/V\% (2 ml). ${ }^{a} I$. Módszer: $80^{\circ} \mathrm{C}, 1$ h. II. Módszer: $25^{\circ} \mathrm{C}, 2 \mathrm{~h}$, majd $80^{\circ} \mathrm{C}, 1$ h. ${ }^{b}$ A feltüntetett konverziók GC-MS-el lettek meghatározva. 


\subsection{Fotoizomerizálható határfelületek előállítása PDA hordozón ${ }^{[151]}$}

\subsubsection{Q-PDA-Au előállítása}

Kihasználva a PDA univerzális adhezivitását, kvarc lemezeket merítettünk Tris-puffert tartalmazó dopamin-hidrokolrid oldatba és 24 órán át kevertettük a rendszert. Habár, a polimerizáció gyorsítható oxidálószer hozzáadásával, mi a levegőben lévő oxigén használata mellett döntöttünk, hogy elkerüljük a felület szennyezését szervetlen sókkal, amik esetlegesen befolyásolhatják a felületmódosítás kimenetelét, vagy zavarhatják a felületek analitikáját. ${ }^{[152,}$ ${ }^{153]}$ A kvarclapokon vékony, sötétbarna film képződését figyeltük meg (Q-PDA), amelynek abszorpciós spektrumán szélessávú, egyenletes fényelnyelés látható az UV régiótól egészen a közeli infravörös tartományokig (34. ábra, $a$ ). Az így előállított PDA vékonyréteg UV-Vis transzmittanciája megfelelőnek bizonyult, hogy a felületen bekövetkező további változásokat spektrofotometriával kövessük. A lemezeket ezután $\mathrm{AuCl}_{3}$ x $3 \mathrm{H}_{2} \mathrm{O}$ vizes oldatába merítettük. 1 óra elteltével, szemmel látható lila elszíneződést figyeltünk meg, ami a szilárd fázisú abszorpciós spektrumon, az Au nanorészecskékre jellemző, 550 nm körüli elnyelési sávként jelent meg. További 2 óra eltelte után az abszorpciós sáv intenzitása és szélessége megnőtt, maximuma enyhén vörös-eltolódott $\approx 560 \mathrm{~nm}$ környékére (34. ábra, $b$ ). XPS mérések is igazolták $\mathrm{Au}(0)$ megjelenését a felületen (Melléklet, 1. ábra).
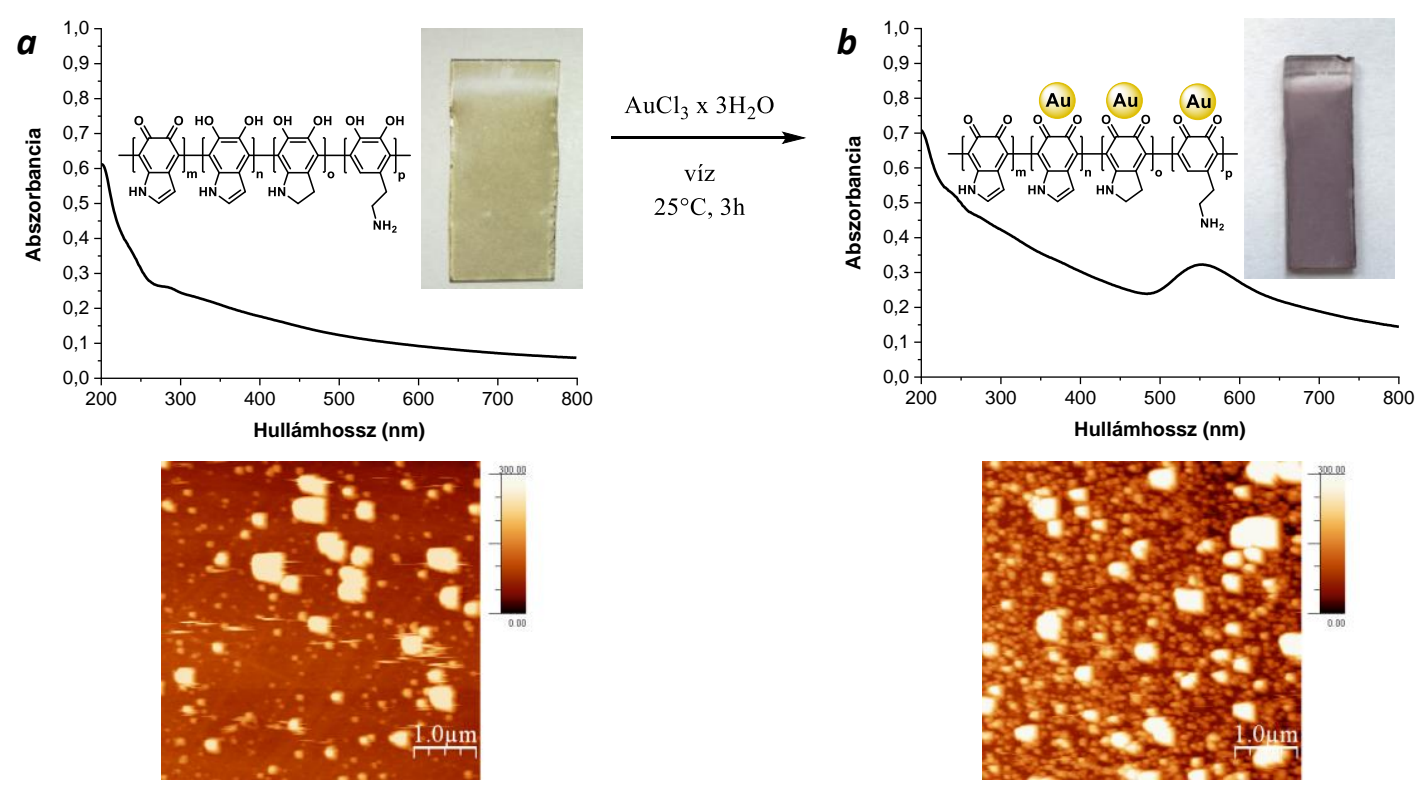

34. ábra (a) Q-PDA abszorpciós spektruma, és makroszkopikus képe, valamint AFM képe. (b) QPDA-Au abszorpciós spektruma a jellegzetes $560 \mathrm{~nm}$ körüli elnyeléssel, amelyet lila színủ $\mathrm{Au}$ nanorészecskék megjelenése okoz, valamint a Q-PDA-Au AFM képe, amin nagy diszperzitású 50 - 80 nm-es Au részecskék láthatóak. 
Az előállított felületeket mikroszkópiásan is jellemeztük. Az AFM képeken jól megfigyelhető, hogy a Q-PDA lemezeken egyenletes polimerréteg található, amely elszórtan, a polimerizáció során a felületre kitapadt 50 - 150 nm-es PDA részecskéket tartalmaz, amelyek ellenálltak a felület tisztítása során alkalmazott ultrahangos kezelésnek is (34. ábra, a, AFM kép). 3 óra $\mathrm{Au}(\mathrm{III})$ redukciót követően a felület egyenetlensége megnőtt, $50-80 \mathrm{~nm}$ átméröjü $\mathrm{Au}$ nanorészecskék keletkeztek (Q-PDA-Au; 34. ábra, b, AFM kép). A nagy mennyiségü, magas diszperzitású $\mathrm{Au}$ részecskét tartalmazó felület előnyösnek tünt fotoizomerizálható molekulák rögzítésére, ezért hosszabb Au(III) redukciós idővel nem kísérleteztünk, az ugyanis nagyobb részecske aggregátumokat, valamint rendezettebb, sík felülethez hasonlító geometriájú felületet eredményezne (lásd még: 14. ábra, $a$ ), ami már nem kedvez a fotoizomerizációnak. Mind a Q-PDA, mind pedig a Q-PDA-Au felület hidrofil sajátságúnak bizonyult víz-kontaktszög mérések alapján (7. táblázat).

\subsubsection{Azobenzol származékok szintézise}

A felületi fotoizomerizáció és a ligandumcsere vizsgálatához a 35, és 36. ábrán látható, különböző funkciós csoportokkal rendelkező azobenzolszármazékokat terveztük előállítani. Az alkil-tiol végcsoportot tartalmazó molekulák $\left(\mathrm{AzoC}_{3} \mathrm{SH}, \mathrm{AzoC}_{6} \mathrm{SH}\right) \mathrm{Au}$ affinitása nagyobb, mint az alkil-amint tartalmazóké $\left(\mathrm{AzoC}_{6} \mathrm{NH}_{2}\right)$, ami megkönnyítheti egy esetleges ligandumcsere kivitelezését ${ }^{[132,154]}$. Ahhoz, hogy teszteljük a különböző hosszúságú alkil-láncok közt ébredő van der Waals kölcsönhatások molekularéteget stabilizáló hatását, valamint az izomerizálhatóságot, propil-, és hexil-lánccal rendelkező származékokat is előállítottunk $\left(\mathrm{AzoC}_{3} \mathrm{SH}, \mathrm{AzoC}_{6} \mathrm{SH}\right)$. Dimetil-amin funkció beépítésével az azobenzol egység 4'-helyzetébe $\left(\mathrm{Me}_{2} \mathrm{NAzoC}_{6} \mathrm{SH}\right)$, a szubsztituálatlan azofenol származékokhoz képest eltolható a molekula abszorpciós maximuma a látható spektrális tartomány felé (37. ábra, $a, b, c$, vs. d). ${ }^{[136]}$ Így, egyrészt spektroszkópiai úton könnyen követhetővé válik a különböző abszorpciós maximumokkal rendelkező azobenzol származékok ligandumcseréje, másrészt, olyan többkomponensű molekularéteget hozhatunk létre, amelynek komponenseit más-más hullámhosszakon tudjuk izomerizálni.

$\mathrm{Az} \mathrm{AzoC}_{6} \mathrm{NH}_{2}, \mathrm{AzoC}_{6} \mathrm{SH}$, és $\mathrm{AzoC}_{3} \mathrm{SH}$ szintéziséhez elöször elő kellett állítanunk azofenolt (35. ábra, 65), melyet anilin $\mathrm{NaNO}_{2}$-el történő diazotálásával, majd ezt követően, a diazónium-só fenollal történő reakciójával nyertünk. A fenolszármazék $\mathrm{K}_{2} \mathrm{CO}_{3}$ bázis jelenlétében könnyen deprotonálható, így nukleofil szubsztitícióban vehet részt alkilbromidokkal. Így, a megfelelő hosszúságú szénláncot tartalmazó $\alpha$, $\omega$-dibróm-alkánnal alkilezve az azofenolt, jutottunk el a 66 és 67 vegyületekhez. A dibróm-alkánt azonban 
ötszörös feleslegben kellett alkalmaznunk, hogy elkerüljük a diszubsztituált alkán keletkezését. A terminális brómszubsztituens aminra történő cseréjét két lépésben oldottuk meg: először $\mathrm{NaN}_{3}$-al azidot képeztünk (35. ábra, 68), majd az azidot $\mathrm{LiAlH}_{4}$-el redukáltuk aminná, így előállítva az $\mathrm{AzoC}_{6} \mathrm{NH}_{2}$-t. Tiol végcsoportot is két lépésben sikerült kialakítanunk. Először $\mathrm{Na}_{2} \mathrm{~S}_{2} \mathrm{O}_{3} \times 5 \mathrm{H}_{2} \mathrm{O}$-val úgynevezett Bunte-sót képeztünk (35. ábra, 69), mely teljes konverzióval megtörtént, így nem kellett átkristályosítanunk a terméket. Végül, a Bunte-só savas hidrolízisével jutottunk el az AzoC $\mathrm{C}_{3} \mathrm{SH}$, és $\mathrm{AzoC}_{6} \mathrm{SH}$ termékekhez.
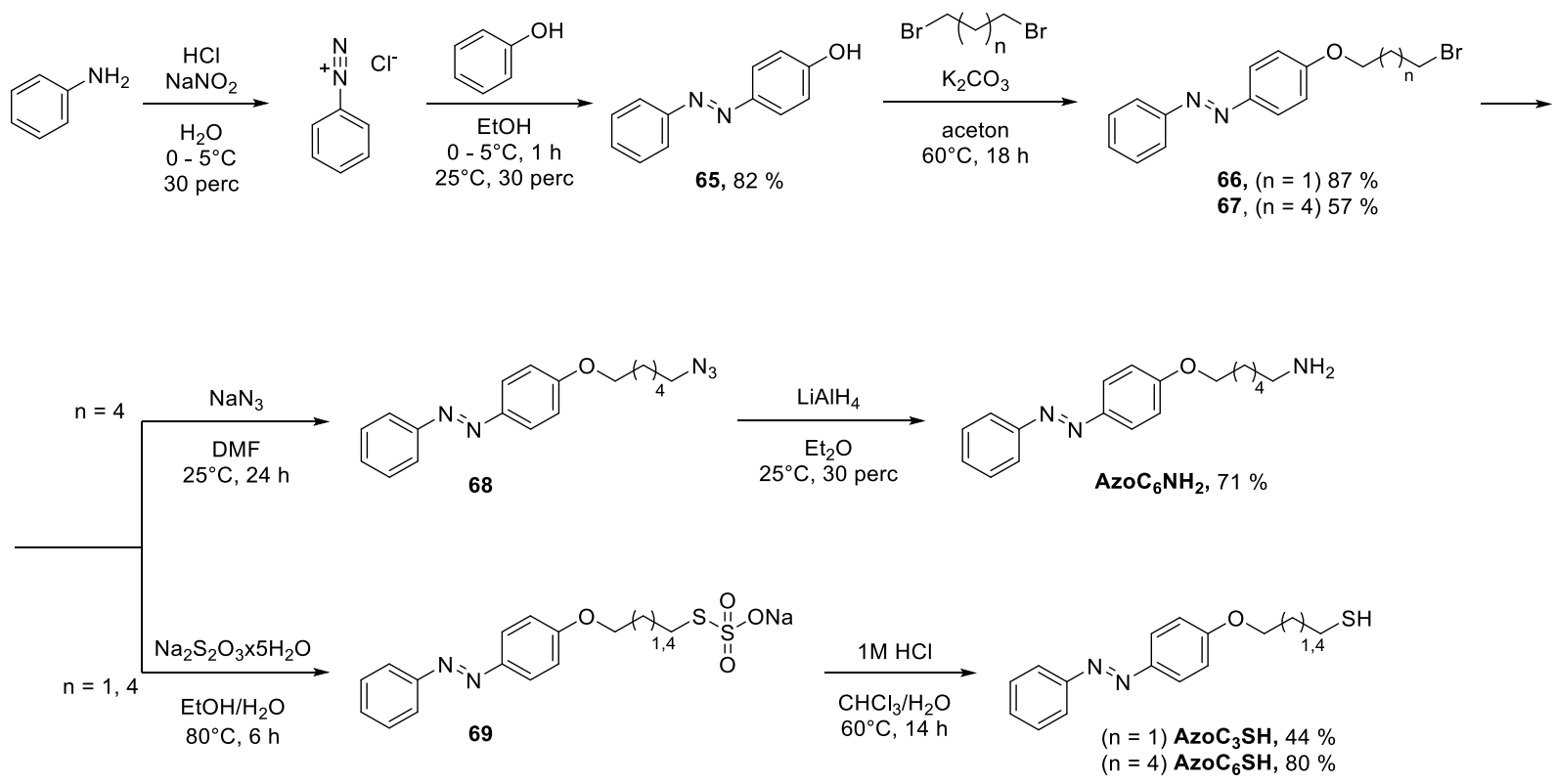

35. ábra Azofenol származékok szintézisútjai.

$\mathrm{Me}_{2} \mathrm{NAzoC}_{6} \mathrm{SH}$ előállításához változtatnunk kellett a fentebb leírt úton (36. ábra). 4-Aminofenol izopentil-nitrittel történő diazotálásával, majd a diazóniumsó $N, N$-dimetilanilinnel történő azokapcsolásával jutottunk a 70-es számú vegyülethez. Alkilezését a fentebb ismertetett módon sikerült kivitelezni 1,6-dibróm-hexánnal, amit tiokarbamid segítségével alakítottunk tovább a megfelelő tiollá. Erre azért volt szükség, mert $\mathrm{Na}_{2} \mathrm{~S}_{2} \mathrm{O}_{3} \times 5 \mathrm{H}_{2} \mathrm{O}$-val nem tudtuk teljes konverzióval kialakítani a Bunte-sót, az átkristályosítás túlságosan körülményes volt, így amikor a kiindulási anyaggal szennyezett sót elhidrolizáltuk, a keletkezett tiolt nem lehetett oszlopkromatográfiával elválasztani 71-től, megegyező polaritásuk miatt. Az izotiourónium-só (36. ábra, 72) azonban hexán/etanol elegyben történő digerálással elkülöníthető volt a kiindulási brómvegyülettől, így lúgos hidrolízis során tisztán hozzájutottunk az $\mathrm{Me}_{2} \mathrm{NAzoC}_{6} \mathrm{SH}$-hoz. 


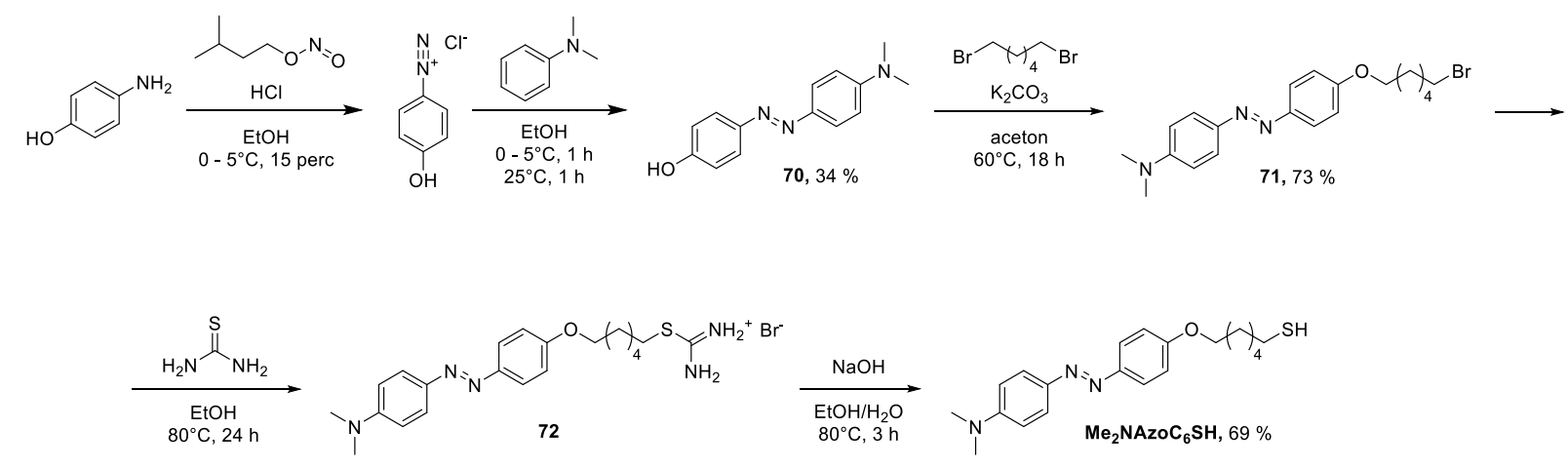

36. ábra $\mathrm{Me}_{2} \mathrm{NAzoC}_{6} \mathrm{SH}$ előállításának szintézisútja.
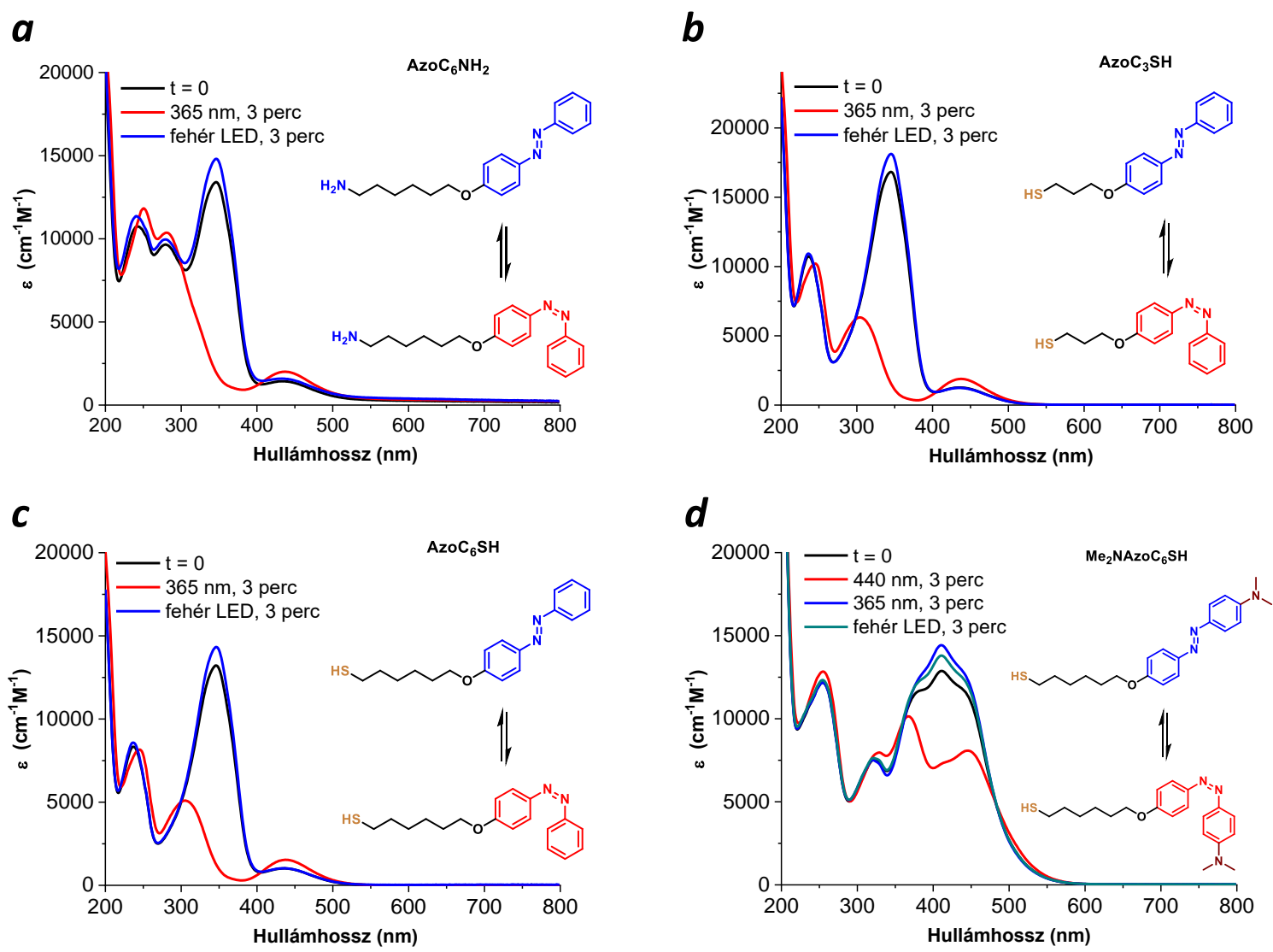

37. ábra $\mathrm{Az}$ előállított azobenzol származékok $\left[(a) \mathrm{AzoC}_{6} \mathrm{NH}_{2},(b) \mathrm{AzoC}_{3} \mathrm{SH},(c) \mathrm{AzoC}_{6} \mathrm{SH},(d)\right.$ $\mathrm{Me}_{2} \mathrm{NAzoC}_{6} \mathrm{SH}$ ], valamint a molekulák moláris abszorbancia spektrumainak változása különböző hullámhosszúságú fény hatására.

Az előállított azobenzol származékok híg MeCN-es oldatban gyors fotoizomerizációs készséget mutattak. Az AzoC ${ }_{6} \mathrm{NH}_{2}, \mathrm{AzoC}_{3} \mathrm{SH}$, és $\mathrm{AzoC}_{6} \mathrm{SH}$ molekulák percek alatt $(<3$ perc) cisz izomerré alakultak $365 \mathrm{~nm}$ hullámhosszú fény hatására, míg fehér fény jelenlétében visszaizomerizáltak transz formába (37. ábra, $a, b, c)$. Ezzel szemben, céljainknak 
megfelelöen, a $\mathrm{Me}_{2} \mathrm{NAzoC}_{6} \mathrm{SH}$ esetén magasabb, $440 \mathrm{~nm}$-es hullámhosszon tudtuk cisz izomerré alakítani a molekulát, viszont $365 \mathrm{~nm}$ és fehér fény hatására is visszakaptuk a transz izomerben dúsabb elegyet (37. ábra, $d$ ).

\subsubsection{Q-PDA-Au felület módosítása azobenzol származékokkal}

A tiol-végcsoportú $\mathrm{AzoC}_{6} \mathrm{SH}$ és az amin-végcsoportú $\mathrm{AzoC}_{6} \mathrm{NH}_{2}$ segítségével kerestünk megfelelő reakciókörülményeket a Q-PDA-Au felület módosításához. Megfigyeltük, hogy az oldószer anyagi minősége nagymértékben befolyásolja a határfelületi reakció kimenetelét. Az azofenolokra jellemző 360 nm körüli abszorpciós sáv megjelenését mindkét molekula esetén kizárólag EtOH-t használva figyeltük meg (38. ábra), MeCN, THF, DCM esetén nem láttunk változást a spektrumokon 24 óra reakcióidőt követően sem (Melléklet, 2. ábra). Ennek magyarázata lehet, hogy az EtOH-t kivéve minden kipróbált oldószer rendkívül jó oldószere az azobenzol származékoknak, ezzel gátolva a felületi reakciót, míg az alkalmazott $1 \mathrm{mM}$ koncentrációjú EtOH-os oldatok elkészítéséhez minden esetben ultrahangos kezelést kellett alkalmazni, ami rosszabb oldhatóságra utal. Növelve a reakcióidőt $\left(25^{\circ} \mathrm{C}, 72 \mathrm{~h}\right)$, vagy a hömérsékletet $\left(40^{\circ} \mathrm{C}, 24 \mathrm{~h}\right)$ a $360 \mathrm{~nm}$ körüli abszorpciós sáv intenzitásának növekedését tapasztaltuk, ami a felületen elhelyezkedő nagyobb mennyiségü azobenzol jelenlétére utal (38. ábra, c). A magasabb hőmérséklet növeli az oldatfázisban jelenlevő molekulák, és a felülethez kötött molekulák mobilitását is, ezért a túl magas hőmérséklet általában a deszorpciónak kedvez híg oldatok esetén. Csökkentve a felületi reakció hőmérsékletét $6^{\circ} \mathrm{C}$-ra, ezért nem meglepő módon kevesebb molekula jelent meg a felületen a $40^{\circ} \mathrm{C}$-on végzett módosításhoz képest (Melléklet, 2. ábra). Mivel az $\mathrm{AzoC}_{6} \mathrm{SH}$ és az $\mathrm{AzoC}_{6} \mathrm{NH}_{2}$ molekulákat megegyezö körülmények között $\left(1 \mathrm{mM}, \mathrm{EtOH}, 40^{\circ} \mathrm{C}, 24 \mathrm{~h}\right)$ sikerült legnagyobb mértékben a felületre vinni, ezért a továbbiakban is ezt a módszert használtuk a Q-PDA-Au felületek módosításához. Mint az az abszorpciós spektrumokból kiderült, az $\mathrm{AzoC}_{3} \mathrm{SH}$ és az $\mathrm{Me}_{2} \mathrm{NAzoC}_{6} \mathrm{SH}$ is eredményesen, megfelelő koncentrációban rögzíthetők voltak Q-PDA-Au felületen (40. ábra). 

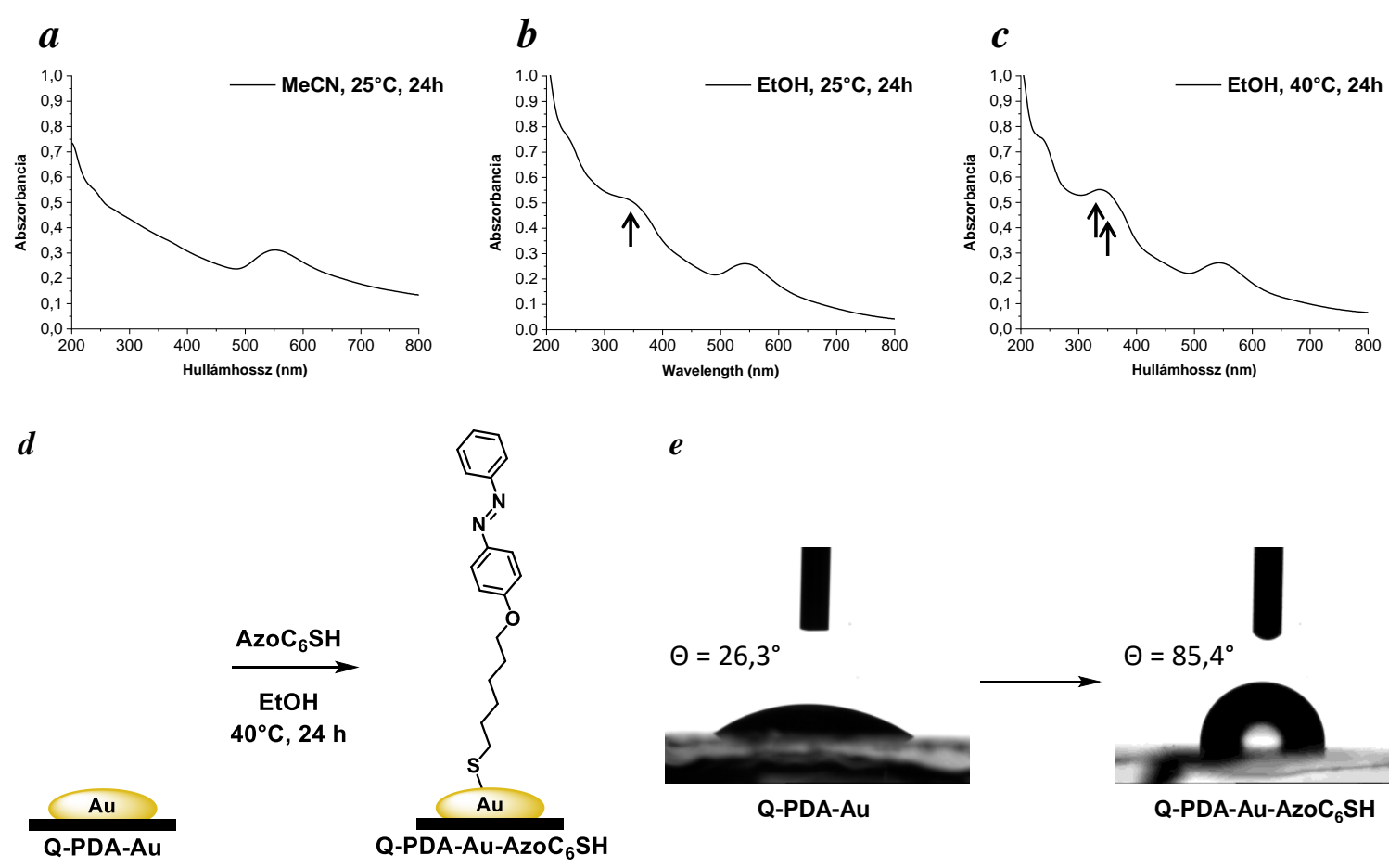

$\boldsymbol{e}$

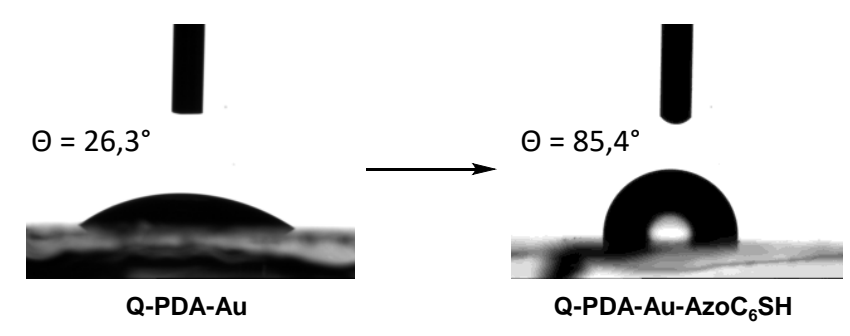

38. ábra Q-PDA-Au felület módosítása $\mathrm{AzoC}_{6} \mathrm{SH}-\mathrm{val}(\mathrm{c}=1 \mathrm{mM})$ különbözö körülmények között. $\mathrm{A}$ molekulára jellemzö, $360 \mathrm{~nm}$ körüli abszorpciós sáv megjelenését kizárólag $(b, c)$ EtOH oldószert használva figyeltük meg. Magasabb hőmérsékleten $\left(c, 40^{\circ} \mathrm{C}\right)$ végzett reakció esetén a sáv intenzitása megnőtt. A felületmódosítás $(d)$ sematikus ábrázolása, és $(e)$ követése kontaktszög méréssel.

A szakirodalomban leírt jelenség aminok ${ }^{[155]}$ és tiolok ${ }^{[156]}$ reakciója PDA-val, ezért megvizsgáltuk, hogy az általunk választott körülmények között történik-e felületi reakció $\mathrm{Au}$ mentes Q-PDA felület és $\mathrm{AzoC}_{6} \mathrm{NH}_{2}$, valamint $\mathrm{AzoC}_{6} \mathrm{SH}$ között. A PDA UV-Vis elnyelésétől alig elkülönülő abszorpcióemelkedés történt a spektrumokon $360 \mathrm{~nm}$ körül, ami elhanyagolható mennyiségủ azobenzol jelenlétére utal a Q-PDA-Au felületen megjelenő azobenzol mennyiségéhez képest (39. ábra). Továbbá, XPS mérések eredményei is Au felülethez kötött tiolok jelenlétére utalnak (Melléklet, 3. ábra). 


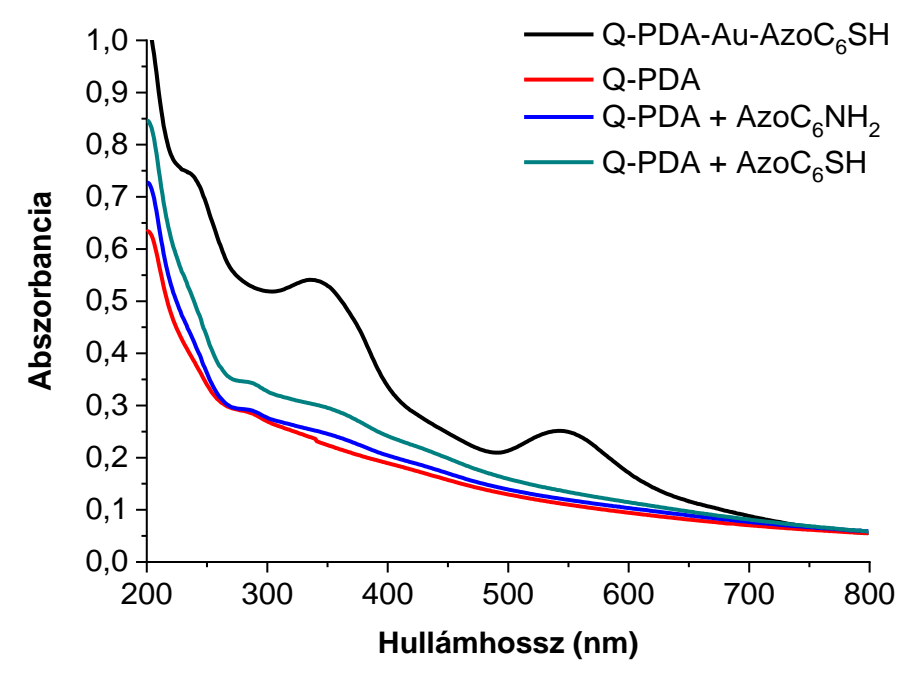

39. ábra $\mathrm{AzoC}_{6} \mathrm{NH}_{2}$-vel (kék), és $\mathrm{AzoC}_{6} \mathrm{SH}$-val (zöld) kezelt ( $\left.1 \mathrm{mM}, \mathrm{EtOH}, 40^{\circ} \mathrm{C}, 24 \mathrm{~h}\right) \mathrm{Au}$ nanorészecske mentes Q-PDA felületek abszorpciós spektrumai összehasonlítva a Q-PDA-Au$\mathrm{AzoC}_{6} \mathrm{SH}$ spektrumával (fekete). A Q-PDA felületen elhanyagolható mennyiségü amin-, és tiolterminális azobenzol jelenik meg.

A molekulák megjelenése radikális változást okozott a felület hidrofilitásában, ami víz-kontaktszög mérésekkel könnyen követhető volt (38. ábra, $e$, és 7. táblázat). Ez a jelentős kontaktszög növekedés a kezdeti hidrofil sajátságú Q-PDA-Au felülethez képest, az apoláris molekulák sürü rétegének megjelenésére utal.

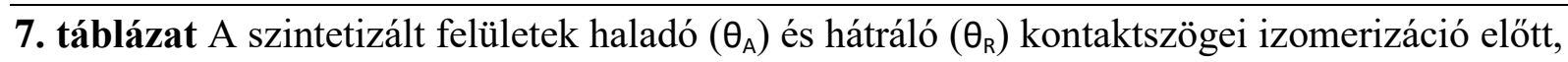
és után.

\begin{tabular}{clcccc}
\hline Sor & \multicolumn{1}{c}{ Minta } & $\theta_{\mathrm{A}}\left({ }^{\circ}\right)$ & $\theta_{\mathrm{R}}\left({ }^{\circ}\right)$ & $\theta_{\mathrm{A}, \text { Irrad }}\left({ }^{\circ}\right)$ & $\theta_{R, \text { Irrad }}\left({ }^{\circ}\right)$ \\
\hline 1 & Q-PDA & $25,6( \pm 3,7)$ & $8,1( \pm 1,7)$ & - & - \\
2 & Q-PDA-Au & $26,3( \pm 2,8)$ & $8,3( \pm 2,4)$ & - & - \\
3 & Q-PDA-Au-AzoC $6 \mathrm{NH}_{2}$ & $79,5( \pm 1,7)$ & $52,9( \pm 2,1)$ & $64,0( \pm 3,0)^{a}$ & $22,0( \pm 3,0)^{a}$ \\
4 & Q-PDA-Au-AzoC ${ }_{3} \mathrm{SH}$ & $90,1( \pm 4,1)$ & $52,7( \pm 4,4)$ & $80,6( \pm 3,3)^{a}$ & $19,3( \pm 4,0)^{a}$ \\
5 & Q-PDA-Au-AzoC 6 SH & $85,4( \pm 3,1)$ & $26,8( \pm 4,6)$ & $73,1( \pm 4,8)^{a}$ & $16,3( \pm 4,6)^{a}$ \\
\multirow{2}{*}{6} & Q-PDA-Au- & $75,8( \pm 2,6)$ & $18,9( \pm 3,1)$ & $60,1( \pm 3,6)^{b}$ & $16,4( \pm 4,2)^{b}$ \\
\hline
\end{tabular}

A méréseket minden felületen 7 - 9 különböző pontban végeztük el, majd a kapott adatokat átlagoltuk.

A 20 percig besugárzott mintákon azonnal mértük a haladó $\left(\theta_{A}\right.$, Irrad $)$ és a hátráló $\left(\theta_{R}\right.$, Irrad kontaktszögeket. (a) $365 \mathrm{~nm}$-es fénnyel történt a besugárzás, (b) Q-PDA-Au-Me ${ }_{2} \mathrm{NAzoC}_{6} \mathrm{SH}$ esetén 440 nm-es fénnyel történt a besugárzás. 


\subsubsection{Azobenzol származékok izomerizációja a módosított felületeken}

Minden Q-PDA-Au felülethez rögzített azobenzol származék transz $\rightarrow$ cisz izomerizáción ment keresztül a megfelelő hullámhosszú fénybesugárzás hatására. A Q-PDA$\mathrm{Au}-\mathrm{AzoC}_{6} \mathrm{NH}_{2},-\mathrm{AzoC}_{3} \mathrm{SH}$, és az $-\mathrm{AzoC}_{6} \mathrm{SH}$ esetén az azofenolokra jellemző $360 \mathrm{~nm}$ körüli elnyelési sáv intenzitásának jelentős csökkenését figyeltük meg $365 \mathrm{~nm}$ hullámhosszú fénnyel 5 percig tartó besugárzást követően (40. ábra, $a, b, c$ ). Ez meglehetősen gyors változást jelent a felületen elhelyezkedő molekulák konfigurációjában, főleg a rövid propil-lánccal rendelkező $\mathrm{AzoC}_{3} \mathrm{SH}$ esetén, amelynek $\mathrm{Au}$ hordozón megfigyelt gátolt izomerizációs képességéről számoltak be korábbi publikációkban. ${ }^{[137,157]}$ A mi esetünkben bekövetkező izomerizációra egy lehetséges magyarázat lehet a PDA valamilyen elektronikus interakciója az Au nanorészecskékkel, aminek hatására nem tud megtörténni az azobenzol egység gerjesztett állapotának legerjesztődése. Hasonló mechanizmusról számoltak be fém/PDA rendszerek katalitikus aktivitását vizsgáló tanulmányban is. ${ }^{[50]}$ A Q-PDA-Au felülethez kötött $\mathrm{Me}_{2} \mathrm{NAzoC}_{6} \mathrm{SH}$ transz $\rightarrow$ cisz izomerizációjához lényegesen hosszabb időre volt szükség, az MeCN oldatban megfigyeltekhez képest (40. ábra, $d$ ). $440 \mathrm{~nm}$-es fény hatására már pár perc alatt látható volt változás a szilárd fázisú abszorpciós spektrumon a származékra jellemző 411 nm körüli sávban, azonban 20 perc besugárzásra volt szükség, hogy a sáv intenzitásának további csökkenése ne legyen megfigyelhető. A molekulák transz $\rightarrow$ cisz izomerizációját kontaktszög mérésekkel is követtük (7. táblázat). Minden módosított felület esetén lényeges növekedést detektáltunk a besugárzott felületek hidrofilicitásában (kisebb kontaktszög), amely a nagyobb dipólusmomentumú cisz-izomerek megjelenésének köszönhető. 

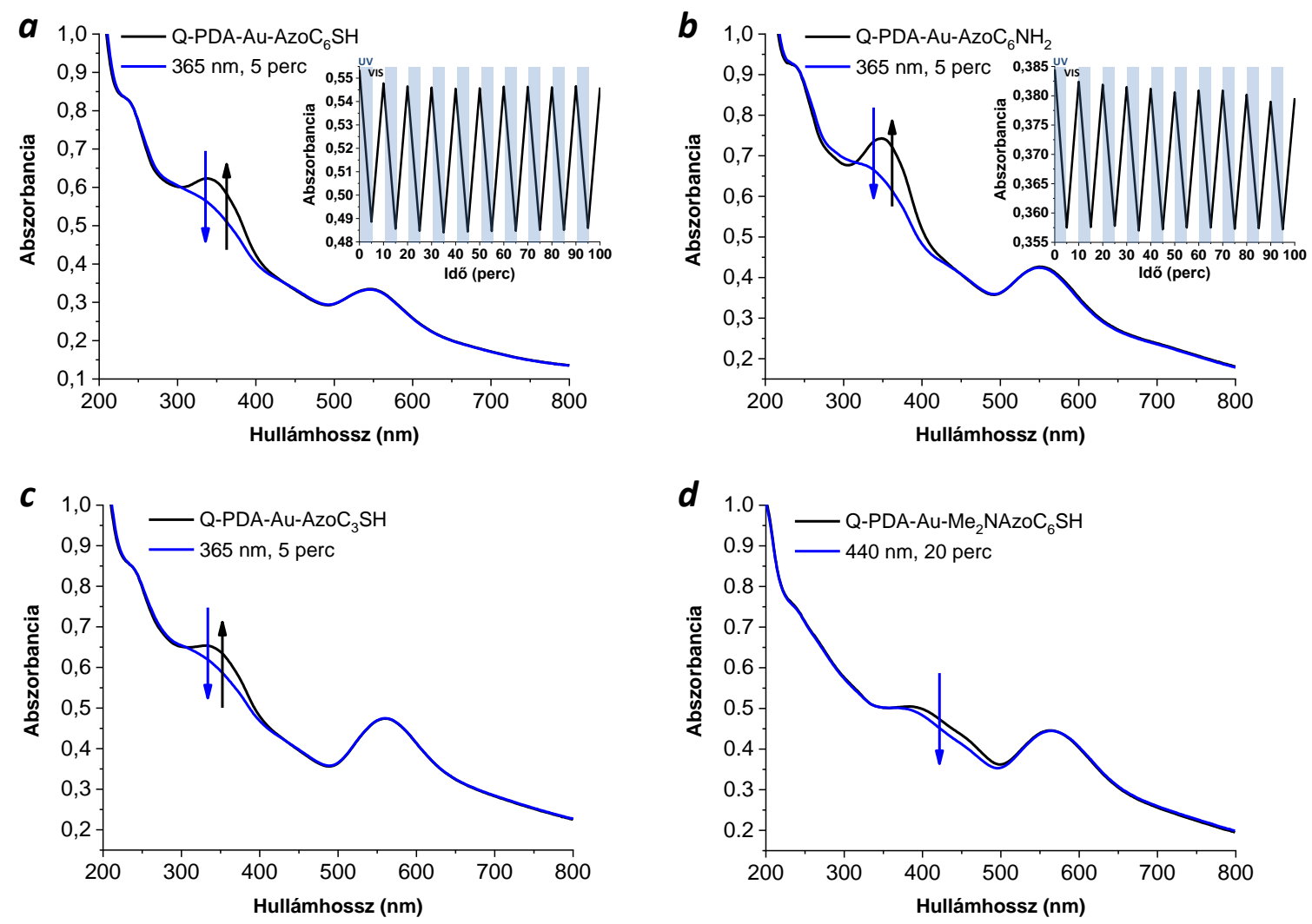

40. ábra Q-PDA-Au felületen rögzített azobenzol származékok besugárzás előtti (fekete), és utáni (kék) szilárd fázisú UV-Vis spektrumai, valamint $a$, és $b$ esetén egy minta felváltva UV- és fehér fénnyel $10 \mathrm{db}$ 5-5 perces ciklusban történő besugárzás hatására bekövetkező abszorpcióváltozása az elnyelési maximimban $(360 \mathrm{~nm})$ mérve.

Miközben a transz $\rightarrow$ cisz átalakulás besugárzás hatására viszonylag gyors folyamatnak bizonyult a módosított felületeken, addig a termikus cisz $\rightarrow$ transz relaxációt vizsgálva a Q-PDA-Au-AzoC ${ }_{6} \mathrm{SH}$ esetén, $20^{\circ} \mathrm{C}$-on 18 órára volt szükségünk, hogy visszakapjuk a termikusan stabilabb transz izomert. Ezzel szemben, fehér fénnyel besugározva a cisz izomerben dús Q-PDA-Au-AzoC ${ }_{6} \mathrm{NH}_{2},-\mathrm{AzoC}_{6} \mathrm{SH}$, és $-\mathrm{AzoC}_{3} \mathrm{SH}$ felületeket, 3 - 5 perc alatt bekövetkezett a transz formába való visszaizomerizáció. Fontos megjegyeznünk, hogy nem történt detektálható degradáció a Q-PDA-Au-AzoC ${ }_{6} \mathrm{NH}_{2}$, és $-\mathrm{AzoC}_{6} \mathrm{SH}$ fotokróm egységében, amennyiben 5-5 perces ciklusokban $365 \mathrm{~nm}$ hullámhosszú, valamint fehér fénnyel felváltva, cisz és transz formába izomerizáltuk őket 10 cikluson keresztül (40. ábra, $a, b$ ). Mindezen megfigyelések a módosított felületek magas fokú termikus stabilitásáról, és fotostabilitásáról tanúskodnak.

Nem ez a helyzet a vörös-eltolódott abszorpciós maximummal rendelkező $\mathrm{Me}_{2} \mathrm{NAzoC} \mathrm{C}_{6} \mathrm{SH}$ esetén. Se spektroszkópiai úton, se kontaktszög mérésekkel nem detektáltunk 
cisz $\rightarrow$ transz izomerizációt se $365 \mathrm{~nm}$, se fehér fénnyel történő besugárzás hatására (40. ábra, d). Csupán kis mértékben növekedett az abszorpciós sáv intenzitása és a kontakszög, amennyiben a felületet $80^{\circ} \mathrm{C}$-on 18 órán át tartottuk. Mivel oldatban az $\mathrm{Me}_{2} \mathrm{NAzoC}_{6} \mathrm{SH}$ gyors, nagy fokú cisz $\rightarrow$ transz izomerizációját figyeltük meg, ezért úgy gondoljuk, hogy a dimetilamin szubsztituens tercier nitrogénjének elektronpárja vagy az Au felülethez koordinálva, vagy a PDA katekol és amin funkcióival hidrogén kötéseket kialakítva gátolta meg a transz izomerré visszaalakulást (41. ábra). Hasonló szubsztitúciós mintázatú azobenzolszármazék csökkent cisz $\rightarrow$ transz izomerizációs készségéről korábbi publikációkban is beszámoltak. ${ }^{[136,}$ $158,159]$

a

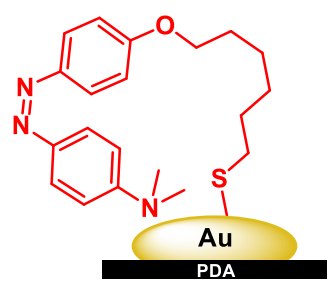

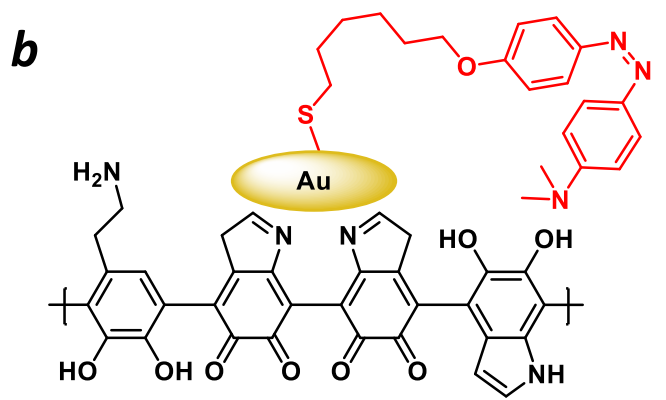

41. ábra $\mathrm{Me}_{2} \mathrm{NAzoC}_{6} \mathrm{SH}$ tercier nitrogénjének $(a)$ koordinációja Au felülethez, $(b)$ hidrogénkötés kialakítása a PDA hidroxil-csoportjával.

\subsubsection{Ligandumcsere Q-PDA-Au felületen}

Makroszkopikus felületen végrehajtott ligandumcserével létrehozhatunk egy, a kezdetitől eltérő funkcióval rendelkező molekularéteget, vagy egy többkomponensű felületet (42. ábra). Ezek a molekuláris újrarendeződési folyamatok lehetővé teszik, hogy ne kelljen újra és újra alkotóelemeiböl felépítenünk a rendszerünket, hanem elegendő legyen csak a legkülső molekularéteget lecserélni. Így nem csak időt és energiát spórolhatunk, de csökkenthetjük a keletkező melléktermékek mennyiségét is, ezzel egy egyszerü, könnyen kezelhetö, robosztus rendszert teremtve.

Úgy véltük, hogy a Q-PDA-n elhelyezkedő, nagy felületi görbülettel rendelkező Au nanorészecskék elősegíthetik a nagy hatásfokú ligandumcserét. Ennek vizsgálatára először létrehoztunk egy $n$-propil-aminnal módosított felületet (Q-PDA-Au- $n \operatorname{PrNH}_{2}$, 42. ábra $a$ ), amit $\mathrm{Me}_{2} \mathrm{NAzoC}_{6} \mathrm{SH} 1 \mathrm{mM}$-os etanolos oldatába merítettünk, és $40^{\circ} \mathrm{C}$-on tartva, adott időközönként rögzítettük a szilárd minta UV-Vis spektrumát (42. ábra $b$ ), valamint kontaktszöget mértünk (42. ábra $c$ ). A tiol-Au interakciónál gyengébb amin-Au interakció, és az n-propil láncok kis sztérikus gátlása miatt gyors ligandumcserére számítottunk. A 42. ábra 
$b$, és $c$ részén látható, hogy az idő előrehaladtával a $\mathrm{Me}_{2} \mathrm{NAzoC}{ }_{6} \mathrm{SH}-$ ra jellemző elnyelés, valamint a kontaktszög értéke növekszik. 48 óra elteltével az abszorpciós spektrum közel megegyezett a Q-PDA-Au- $\mathrm{Me}_{2} \mathrm{NAzoC}_{6} \mathrm{SH}$ spektrumával, valamint a kontaktszög is megközelítette a tisztán $\mathrm{Me}_{2} \mathrm{NAzoC}_{6} \mathrm{SH}$-t tartalmazó felületen mért értéket, ami a kiindulási felületen elhelyezkedő $n \mathrm{PrNH}_{2}$ teljes cseréjét jelzi.

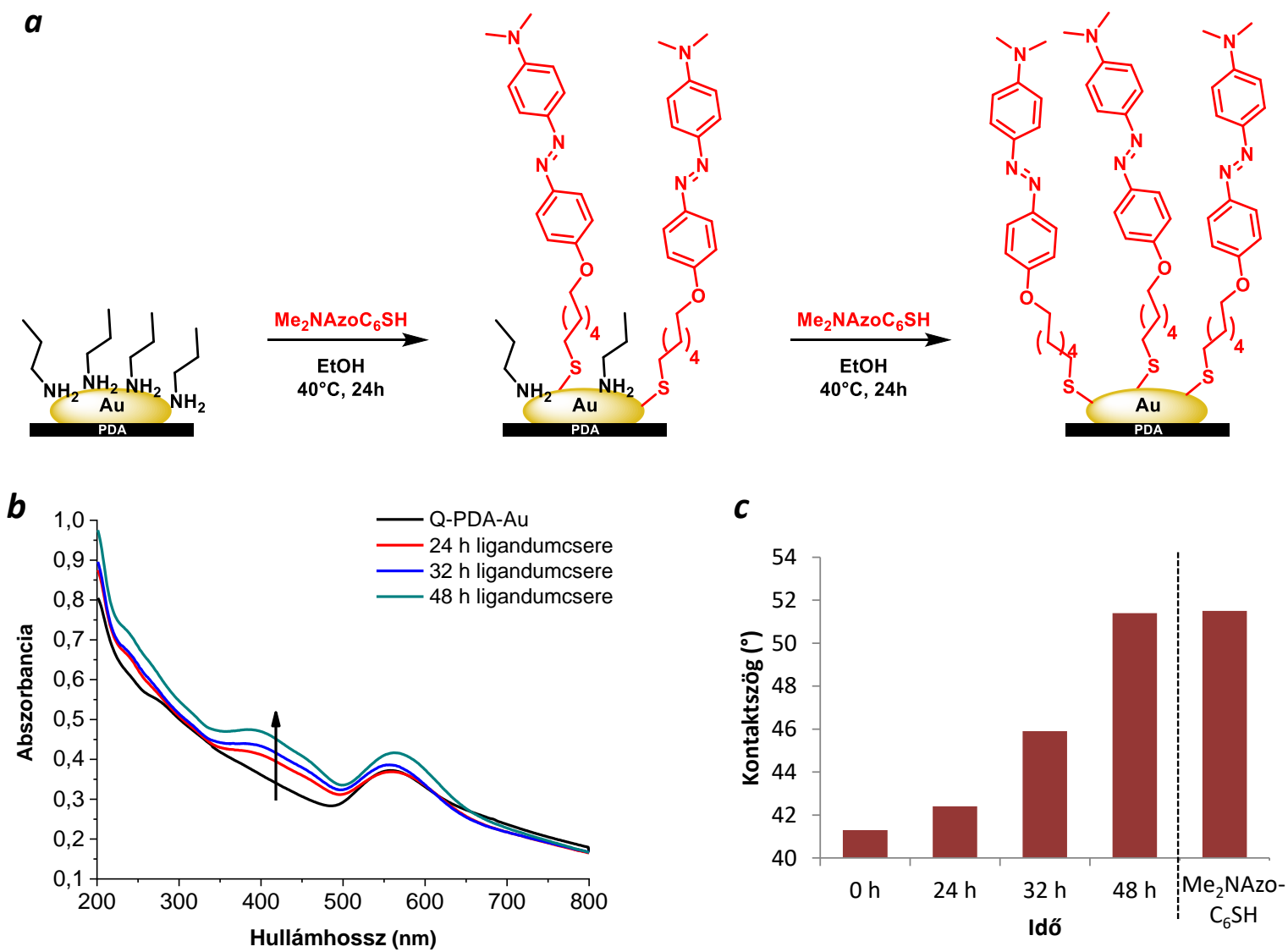

42. ábra (a) Q-PDA-Au felületen történő $n \mathrm{PrNH}_{2} \rightarrow \mathrm{Me}_{2} \mathrm{NAzoC}_{6} \mathrm{SH}$ ligandumcserének sematikus ábrázolása, és a ligandumcsere követése (b) UV-Vis spektrofotometriával és (c) kontaktszög mérésekkel.

Érdekesebb eset egy fotoizomerizálható ligandum cseréje egy másik, eltérő fizikai tulajdonságokkal rendelkező fotoizomerizálható ligandumra. Először a Q-PDA-Au felületre kötött amin-terminális $\mathrm{AzoC}_{6} \mathrm{NH}_{2}$-t kíséreltük meg lecserélni a magasabb hullámhosszon abszorbeáló $\mathrm{Me}_{2} \mathrm{NAzoC} \mathrm{C}_{6} \mathrm{SH}-\mathrm{ra}$, a folyamat spektroszkópiai úton történő könnyebb követhetősége miatt. A Q-PDA-Au-AzoC ${ }_{6} \mathrm{NH}_{2}$ mintát $40^{\circ} \mathrm{C}$-on, 24 órán át tartottuk $\mathrm{Me}_{2} \mathrm{NAzoC}_{6} \mathrm{SH} 1 \mathrm{mM}$-os etanolos oldatában. A 43. ábra $a$ részének abszorpciós spektrumán látható, hogy a $360 \mathrm{~nm}$ körüli elnyelési sáv intenzitása jelentősen csökkent a folyamat során, továbbá megjelent $411 \mathrm{~nm}$ körül a $\mathrm{Me}_{2} \mathrm{NAzoC}{ }_{6} \mathrm{SH}-\mathrm{ra}$ jellemző sáv, jelezve a ligandumcsere 
sikerességét. Hasonló körülmények között a Q-PDA-Au-AzoC ${ }_{3} \mathrm{SH}$, és - $\mathrm{AzoC}_{6} \mathrm{SH}$ cseréjét is elvégeztük $\mathrm{Me}_{2} \mathrm{NAzoC}_{6} \mathrm{SH}$-ra, hogy megvizsgálhassuk az alkillánc hosszának, valamint a tiol végcsoport hatását a cserefolyamatra. Mindkét esetben a $\mathrm{Me}_{2} \mathrm{NAzoC}{ }_{6} \mathrm{SH}-\mathrm{ra}$ jellemző sáv megjelenését, valamint a rövidebb hullámhosszú sáv intenzitásának csökkenését tapasztaltuk (43. $b$, és $c$ ábrák).
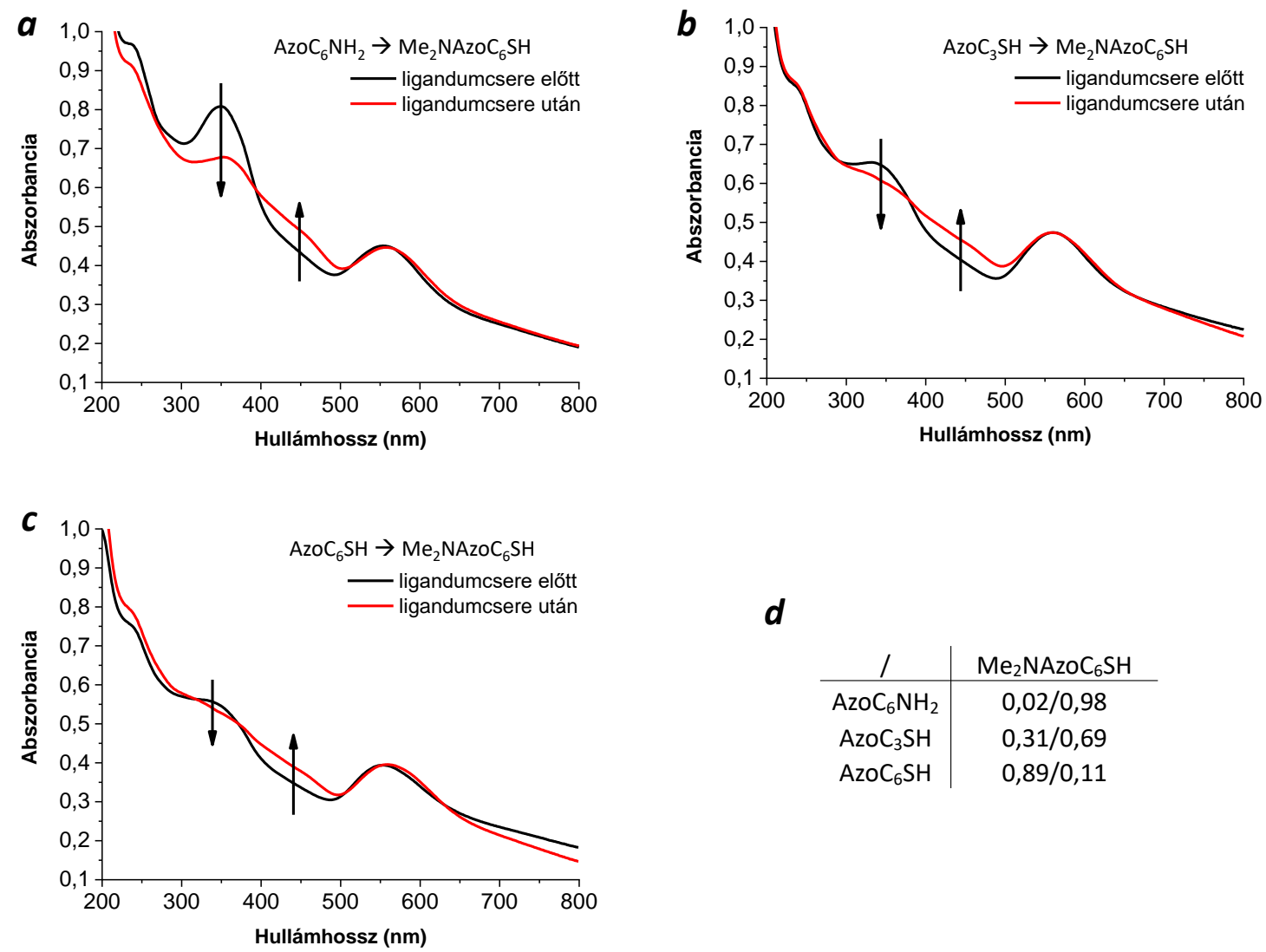

43. ábra $(a, b, c)$ Q-PDA felületen végzett ligandumcserék követése UV-Vis spektrofotometriával, és (d) a cserélt felületeken mért kontaktszögekből számolt közelítő ligandumösszetétel arányok.

Ahhoz, hogy kvantifikáljuk a felületeken keletkezett kevert molekularétegek összetételét, kontaktszögmérésekkel megállapítottuk a felületekhez tartozó átlag haladó-, valamint átlag hátráló kontaktszöget, melyeket felhasználva Wolfram és Faust összefüggésében ${ }^{[160,161]}$ (1. egyenlet), meghatároztuk az egyensúlyi kontaktszöget $\left(\theta_{0}\right)$.

1. egyenlet

$$
\cos \theta_{0}=0,5 \times\left(\cos \theta_{\mathrm{A}}+\cos \theta_{\mathrm{R}}\right)
$$

A heterogén felületekre leírt Cassie-egyenletet ${ }^{[162]}$ alkalmazva (2. egyenlet), a kevert felület egyensúlyi kontaktszöge $\left(\theta_{0}\right.$,mix $)$, valamint a tisztán a cserélendő $\left(\theta_{0, \mathrm{Azol}}\right)$, és tisztán a cserélö 
ligandumot $\left(\theta_{0, \mathrm{Azo} 2}\right)$ tartalmazó felület egyensúlyi kontaktszögéből megkaptuk a felületi ligandumarányt $\left(\mathrm{f}_{\mathrm{Azo1}} / \mathrm{f}_{\mathrm{Azo} 2}\right)$.

2. egyenlet

$$
\cos \theta_{0, \text { mix }}=f_{\text {Azo } 1} \cos \theta_{0, \text { Azo } 1}+f_{\text {Azo } 2} \cos \theta_{0, \text { Azo } 2}
$$

A számolt eredmények alapján a 43. ábra, $d$ táblázatában feltüntetett ligandum-összetétel arányokat kaptuk a 24 órás cserefolyamatokat követően. Jól látszik, hogy az amin-terminális molekulák nagyobb százalékban cseréltek helyet a tiol-terminális $\mathrm{Me}_{2} \mathrm{NAzoC}_{6} \mathrm{SH}$-val adott idő alatt, mint bármelyik tiol-tiol csere esetén. Azonos láncvégi funkció (tiol) mellett a cserélendő molekula alkillánchossza is befolyásolta a folyamatot. A rövidebb, propil-láncú azobenzol cseréje 24 óra után 69 \%-ban megtörtént, míg a hosszabb, hexil-láncú csupán $11 \%$-ban cserélődött le. Ezek a számolt értékek kölcsönösen megerősítik az UV-Vis spektrumokon megfigyelt változásokat. Azonban az $\mathrm{AzoC}_{6} \mathrm{NH}_{2} \rightarrow \mathrm{Me}_{2} \mathrm{NAzoC}_{6} \mathrm{SH}$ csere esetén, míg az abszorpciós spektrumon nem elhanyagolható mennyiségü $A z o C_{6} \mathrm{NH}_{2}$ jelenlétét figyelhetjük meg, addig az egyensúlyi kontaktszögekböl számolt összetétel szerint a ligandumcsere közel teljes volt $(98 \%)$. Tehát, a számolt összetétel arányok elővigyázatossággal kezelendőek, főleg a szakirodalomban megjelent, az eljárást kritizáló publikációk fényében. ${ }^{[163-165]}$ Továbbá meg kell jegyeznünk, hogy a Q-PDA-Au-,AAzo” nem csak heterogén, de egyenetlen, összetett rendszer is, míg a Cassie-egyenletet sík, heterogén felületekre írták le, így a segítségével számolt értékek csupán közelítő jellegüek, ezért a mi esetünkben kizárólag a vizsgált felületek nagyvonalú összehasonlítására alkalmasak.

Felvetődik a ligandumcsere mechanizmusának kérdése. Ehhez Q-PDA-AuAzoC ${ }_{6} \mathrm{NH}_{2}$, és $-\mathrm{AzoC}_{6} \mathrm{SH}$ mintákat kezeltünk a ligandumcsere körülményei között $(\mathrm{EtOH}$, $40^{\circ} \mathrm{C}, 24 \mathrm{~h}$ ), de cserélő ligandum nélkül. A felületi molekulák deszorpciójának mértéke a kötőcsoporttól függött. Az UV-Vis spektrumok alapján 45 \%-al csökkent az amin-terminális azobenzolok mennyisége a felületen, míg a tiol-terminális azobenzolok csak 25 \%-ban deszorbeálódtak 24 óra alatt (Melléklet, 4. ábra). Így, az eddigi eredmények alapján úgy tünik, hogy a deszorpció csak részben játszik szerepet a ligandumcserében, vele párhuzamosan a cserélő ligandum elfoglalhatja nem csak az újonnan létrejövő, de az eredendően jelen lévő szabad helyeket is az Au felületen. Fontos kiemelnünk, hogy egyik lépés után se tapasztaltuk Au nanorészecskék leoldódását a felületről, így a Q-PDA-Au ligandumcsere szempontjából is alkalmazható kompozit felületnek bizonyult.

Részleges felületi ligandumcserével létrehoztunk egy kevert molekularéteget tartalmazó felületet a $365 \mathrm{~nm}$ hullámhosszú fényre izomerizáló $\mathrm{AzoC}_{3} \mathrm{SH}$, és a látható 
tartományba eső, 440 nm-es fényre izomerizáló $\mathrm{Me}_{2} \mathrm{NAzoC}_{6} \mathrm{SH}$ felhasználásával (44. $a$ ábra). Egyrészt kíváncsiak voltunk arra, hogy ligandumcsere után megtartják-e izomerizációs képességüket a molekulák, másrészt az $\mathrm{AzoC}_{3} \mathrm{SH}-\mathrm{t}$ „higító” ligandumként használva célunk a $\mathrm{Me}_{2} \mathrm{NAzoC}_{6} \mathrm{SH}$ izomerizációjának reverzibilissé kényszerítése volt, akár az eltérő izomer formában lévő molekulák közt ébredő másodrendű kölcsönhatásokat kihasználva, akár a megnövelt felületi zsúfoltság segítségével megakadályozni egy erősebb hidrogénkötés kialakulását a PDA és az azobenzol tercier aminja között. A kevert felületet először 365 nmes fénynek tettük ki, aminek hatására az $\mathrm{AzoC}_{3} \mathrm{SH}$ korábban tapasztalt sebességü és mértékü transz $\rightarrow$ cisz izomerizációját figyeltük meg az UV-Vis spektrum $360 \mathrm{~nm}$ körüli tartományában, miközben a $411 \mathrm{~nm}$ körüli, $\mathrm{Me}_{2} \mathrm{NAzoC}_{6} \mathrm{SH}$-ra jellemző régióban nem láttunk változást (44. $b$ ábra). Ezt követően, a mintát $440 \mathrm{~nm}$-es fénnyel besugározva, az $\mathrm{AzoC}_{3} \mathrm{SH}$ transz izomerére jellemző sáv intenzitása megnőtt, amivel párhuzamosan a $\mathrm{Me}_{2} \mathrm{NAzoC}_{6} \mathrm{SH}$ abszorpciós maximuma körül intenzitáscsökkenést figyeltünk meg, ami a cisz forma megjelenésére utalt (44. $c$ ábra). Ezután azonban semmilyen hullámhosszúságú fénnyel (UV/fehér) nem sikerült visszanyerni a $\mathrm{Me}_{2} \mathrm{NAzoC}{ }_{6} \mathrm{SH}$ transz formáját, csupán hőközlés hatására $\left(80^{\circ} \mathrm{C}, 18 \mathrm{~h}\right)$ figyeltük meg a $411 \mathrm{~nm}$ körüli régió intenzitásának elhanyagolható mértékü növekedését a spektrumon (miközben az $\mathrm{AzoC}_{3} \mathrm{SH}$ transz/cisz arány a termikus relaxációnak köszönhetően tovább növekedett; 44. $d$ ábra). 

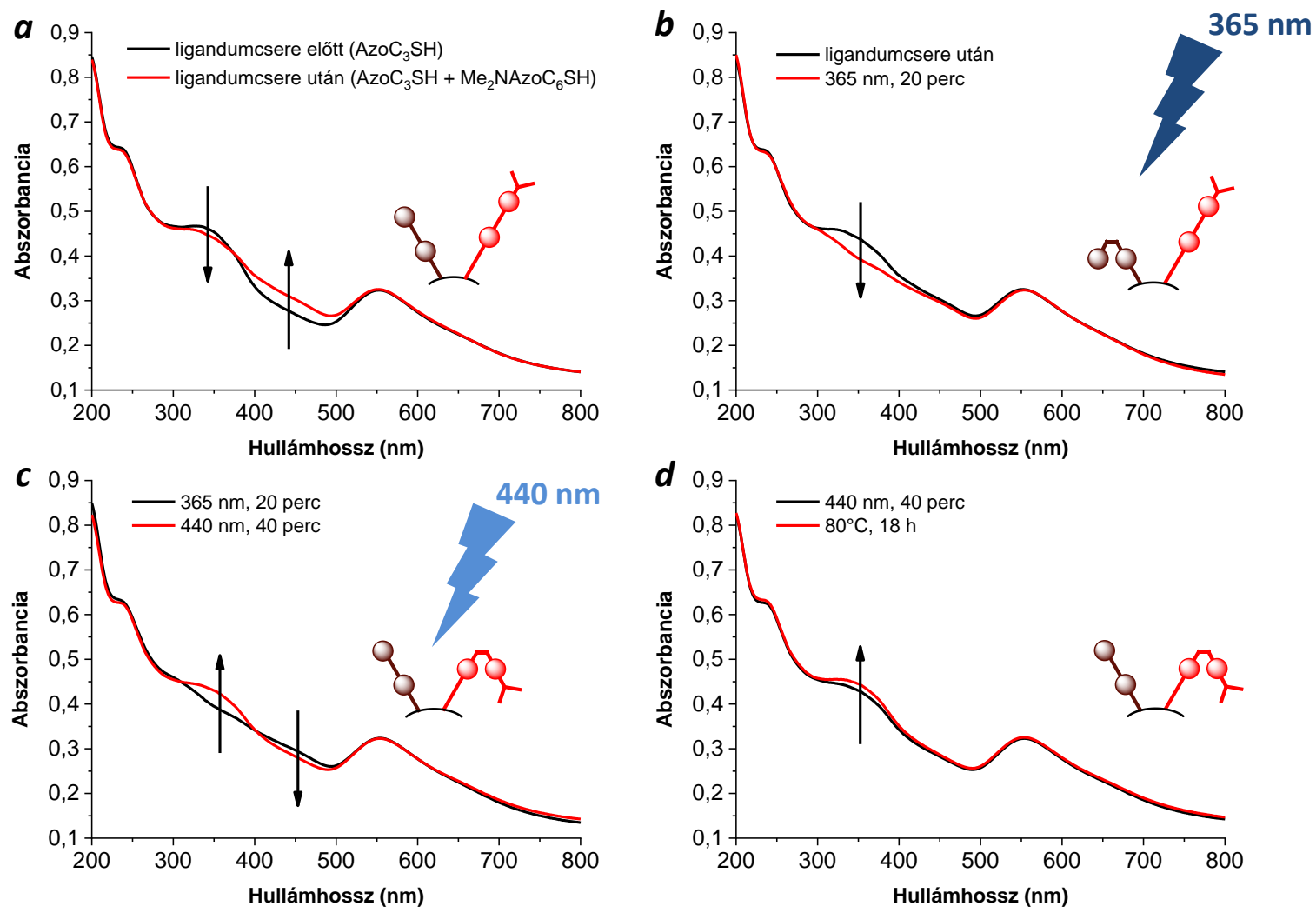

44. ábra (a) Ligandumcsere előtti egykomponensü, és csere utáni, kétkomponensü Q-PDA-Au-,AAzo” felület abszorpciós spektrumai. (b) $365 \mathrm{~nm}$, és (c) $440 \mathrm{~nm}$ hullámhosszú fénybesugárzásnak, valamint (d) $80^{\circ} \mathrm{C}$-nak kitett minta spektrumának változása. A fekete színű spektrum minden esetben az adott lépés előtti állapotot mutatja, a piros, pedig a ligandumcsere/besugárzás utáni spektrum. 


\section{Kísérleti rész}

\subsection{Használt anyagok, müszerek, eljárások}

Vegyszerek, reagensek a Sigma-Aldrich, Fluorochem, VWR, Reanal cégektől kerültek beszerzésre, és további tisztítás nélkül lettek felhasználva. A tisztítási lépésekhez használt oldószerek, eluensek technikai minőségüek voltak. Spektroszkópiai mérésekhez opti-grade jelölésű oldószereket használtunk. Oldatokról az oldószert rotációs vákuumbepárlóval távolítottuk el $25-40^{\circ} \mathrm{C}$ hőmérsékleten. Vékonyréteg kromatográfiához fluoreszcens bevonatú $\mathrm{SiO}_{2}$ állófázist használtunk (VWR), oszlopkromatográfiát $\mathrm{SiO}_{2}-60$ (230-400 mesh ASTM, 40-63 $\mu \mathrm{m}$, Merck) állófázison, $25{ }^{\circ} \mathrm{C}$-on végeztünk, valamint automata oszlopkromatográfiát Teledyne Isco CombiFlash ${ }^{\circledR} \mathrm{Rf}+$ flash kromatográffal végeztünk, $\mathrm{SiO}_{2}$ (25-40 $\mu \mathrm{m}$, Redisep Gold $\left.{ }^{\circledR}\right)$ állófázist alkalmazva. Szobahőmérséklet alatt $24(+/-1)^{\circ} \mathrm{C}$ értendő.

NMR spektrumokat egy Varian 500, valamint egy Varian 300 NMR spektrométeren rögzítettük, 500 és $126 \mathrm{MHz}{ }^{1} \mathrm{H} /{ }^{13} \mathrm{C}$, valamint 300 és $75 \mathrm{MHz}{ }^{1} \mathrm{H} /{ }^{13} \mathrm{C}$ térerősség mellett. Referenciaként a deuterálatlan oldószercsúcsokat használtuk. A kémiai eltolódást $(\delta)$ ppm-ben határoztuk meg. A jelek multiplicitását a következő rövidítésekkel jelöltük az NMR spektrumokon: s, szinglet; d, dublet; $t$, triplet; q, kvartet; $\mathrm{p}$, pentet; $\mathrm{h}$, heptet; $\mathrm{m}$, multiplet. ${ }^{13} \mathrm{C}$ NMR spektrumok szélessávú lecsatolással lettek rögzítve.

UV-Vis spektrofotometriás méréseket egy Jasco V-750 spektrofotométeren végeztük 800 nm-től 200 nm-ig 0,5 és 1 nm-enkénti adatpont rögzítéssel, 1 és 2 nm sávszélességgel, $400 \mathrm{~nm} / \mathrm{s}$ szkennelési sebességgel.

GC-MS analízist egy Shimadzu GCMS-QP2010 Ultra System műszeren, elektronütköztetéses ionizációs módban végeztünk, LC-MS analízist egy Shimadzu LCMS2020 System müszeren, elektronütköztetéses ionizációs módban.

Transzmissziós elektronmikroszkópiához (TEM) a mintákat először etanolban diszpergáltuk, majd a diszperziót egy szén filmmel bevont réz rostéjon bepároltuk. A TEM felvételeket egy Morgagni 268D elektron mikroszkópon $100 \mathrm{kV}$ gyorsítófeszültséget használva rögzítettük. A képeket és az electron diffrakciós mintázatokat SIS Megaview 1K töltéscsatolt kamerával 1376×1032 pixel formátumban rögzítettük. A mérések kivitelezésében segítségünkre volt Dr. Németh Péter, MTA TTK.

Az atomerő mikroszkópiás (AFM) képeket egy Veeco Digital Instrument Multimode AFM eszközzel, Nanoscope ${ }^{\circledR}$ V unit Veeco NanoprobeTM fej segítségével rögzítettük 
k=0,12 N/m rugóállandó mellett. Képfeldolgozáshoz WSxM Develop 3.1 softvert használtunk. A mérések kivitelezésében segítségünkre volt Dr. Keresztes Zsófia, MTA TTK.

Optikai kontaktszögméréshez Dataphysics OCA15+ rendszert használtunk. A mérések zárt, termosztált, telített gőztérben történtek $5 \mu$ l térfogatú vízcsepp felületre vitelével. A maximum haladó $\left(\theta_{\mathrm{A}}\right)$ és minimum hátráló $\left(\theta_{\mathrm{R}}\right)$ kontaktszögek a felületi vízcsepp mennyiségének motor-vezérelt Hamilton fecskendővel végzett változtatásával történtek. A rögzített képek kiértékelését SCA 20 software segítségével, tangens módszerrel analizáltuk. A mérések kivitelezésében, és az eredmények feldolgozásában segítségünkre voltak Dr. Ábrahám Ágnes, és Dr. Kiss Éva, ELTE TTK.

Röntgen fotoelektron spektrumokat (XPS) egy Kratos XSAM 800 spektrométeren rögzítettük $\mathrm{Mg} \mathrm{K \alpha} \alpha_{1,2}(1253,6 \mathrm{eV})$ gerjesztést hazsnálva. A spektrumok $150-1300 \mathrm{eV}$ kinetikus energia tartományon, $0,5 \mathrm{eV}$ léptékkel lettek rögzítve. A kvantitatív analízist a Kratos Vision 2 és a XPS MultiQuant programokkal végeztük. A mérések kivitelezésében, és az eredmények feldolgozásában segítségünkre voltak Dr. Mohai Miklós, és Dr. Bertóti Imre, MTA TTK.

Az izomerizációs kísérletek során a besugárzásokhoz egy Spectroline ENB-280C/FE 8W 365 nm UV fényforrást, egy Euromate 3,4W fehér LED-et, és egy Epistar 10W 440 nm LED-et használtunk.

\subsection{Dopamin tömb-, és filmpolimerizációja, PDA módosítása Pd nanorészecskékkel}

\subsubsection{Pd/PDA előállítása}

Tris bázist (484 mg, 4,0 mmol) feloldottunk oxigénnel 10 percig átbuborékoltatott desztillált vízben $(350 \mathrm{ml})$, és szobahőmérsékleten, 30 percig kevertettük. Ezután dopaminhidroklorid (1,0 g, 5,27 mmol) $50 \mathrm{ml}$ vízzel készült oldatát hozzáadva, 30 órán át kevertettük. A keletkezett sötétbarna szuszpenziót Büchner tölcsér segítségével szürtük, vízzel mostuk (kb. $50 \mathrm{ml})$, majd 18 órán át levegőn szárítottuk. Az így nyert PDA-ból 200 mg-ot Pd(OAc) 2 (21 mg, 0,094 mmol) $50 \mathrm{ml} \mathrm{MeOH-os} \mathrm{oldatában} \mathrm{szuszpendáltuk,} \mathrm{és} \mathrm{intenzíven} \mathrm{kevertettük}$ szobahőmérsékleten, 18 órán át. Ezután a szuszpenziót szürtük, MeOH-lal $(20 \mathrm{ml})$ mostuk, majd levegőn szárítottuk. ICP-MS analízis segítségével 3,30 - 3,53 m/m\% Pd tartalmat állapítottunk meg, ami sarzsonként $6-8 \%$-al változott, ezért minden sarzs előállítása után 
ICP-MS mérést követően határoztuk meg a reakciókban alkalmazott tömegü $(0,5-5,0-10,0$ mg) Pd/PDA katalizátor Pd tartalmát.

\subsubsection{Pd/PDA/MNP előállítása}

$\mathrm{FeSO}_{4} \times 7 \mathrm{H}_{2} \mathrm{O}(7,0 \mathrm{~g}, 25,2 \mathrm{mmol})$ és $\mathrm{Fe}_{2}\left(\mathrm{SO}_{4}\right)_{3}(10,0 \mathrm{~g}, 25,0 \mathrm{mmol}) 250 \mathrm{ml}$ vízzel készült oldatához 25\%-os $\mathrm{NH}_{3}$ oldatot adagoltunk a $\mathrm{pH} \approx 10$-re állításához. Ezután a reakcióelegyet $60^{\circ} \mathrm{C}$-ra melegítve 3 órán át kevertettük, amely során kicsapódott részecskéket külső mágneses térrel szeparáltuk, vízzel mostuk (3 x $20 \mathrm{ml})$, levegőn szárítottuk. Az így előállított MNP-t (500 mg, 2,16 mmol) Tris bázis (200 mg, 1,65 mmol) vizes oldatában (150 ml) szuszpendáltuk, majd motoros keverővel történő erőteljes kevertetés mellett dopaminhidroklorid $(500 \mathrm{mg}, 2,64 \mathrm{mmol})$ vizes oldatát $(20 \mathrm{ml})$ hozzáadva 24 órán át kevertettük. Végül a szuszpenziót külső mágneses tér segítségével elválasztottuk, vízzel $(3 \times 20 \mathrm{ml})$ mostuk, levegőn szárítottuk, és a Pd/PDA előállításánál leírt Pd-redukciós módszert alkalmaztuk. Minden sarzs előállítása után ICP-MS mérés segítségével állapítottunk meg a katalizátor Pd tartalmát, ami sarzsonként eltérő volt.

\subsubsection{Pd/PDA-13 elöállítása}

PDA-t (200 mg) szuszpendáltunk $20 \mathrm{ml}$ vízben, majd Pd(OAc) 2 (70 mg, 0,31 mmol) 5 $\mathrm{ml}$ acetonos oldatához adtuk, és intenzíven kevertettük $90^{\circ} \mathrm{C}$-on, 1 órán át. Ezután a szuszpenziót szürtük, MeOH-lal (20 ml) mostuk, majd levegőn szárítottuk. ICP-MS analízis segítségével 13,47 m/m\% Pd tartalmat állapítottunk meg.

\subsection{Katalitikus átalakítások}

\subsubsection{Transzfer hidrogénezés}

Pd/PDA (10 mg, 0,57 mol\% Pd), reaktáns (0,5 mmol), HCOONa (136 mg, 2,0 mmol; karbonil vegyületek esetén 3,0 mmol), és $96 \mathrm{~V} / \mathrm{V} \% \mathrm{EtOH}(2 \mathrm{ml})$ fiolába juttatása után a fiolát lezártuk, majd $85^{\circ} \mathrm{C}$-on, 1 órán kevertettük a reakcióelegyet. Ezután a lehütött rendszert $2 \mathrm{ml}$ EtOAc-al higítottuk, majd kevés szilikán átszürtük, a szilikát további $20 \mathrm{ml}$ EtOAc-al átmostuk. Az oldószert ezután rotációs vákuumbepárlóval eltávolítottuk, a nyers terméket oszlopkromatográfiával tisztítottuk, a terméket NMR spektroszkópiával jellemeztük. 


\subsubsection{Heck reakció}

Pd/PDA (10 mg, 0,57 mol\% Pd), aril-halogenid (0,5 mmol), etil-akrilát (65 $\mu 1,0,6$ $\mathrm{mmol}$ ), $\mathrm{Na}_{2} \mathrm{CO}_{3}$ (74 mg, 0,7 mmol), $n \mathrm{Bu}_{4} \mathrm{NCl}$ (35 mg, 0,125 mmol), és NMP (2 ml) fiolába juttatása után a fiolát lezártuk, majd a reakcióelegyet $85^{\circ} \mathrm{C}$-on 24 órán át kevertettük. Ezután a lehütött rendszert $2 \mathrm{ml}$ EtOAc-al higítottuk, majd kevés szilikán átszürtük, a szilikát további $20 \mathrm{ml}$ EtOAc-al átmostuk. Az oldószert ezután rotációs vákuumbepárlóval eltávolítottuk, a nyers terméket oszlopkromatográfiával tisztítottuk, a terméket NMR spektroszkópiával jellemeztük.

\subsubsection{Suzuki reakció}

$\mathrm{Pd} / \mathrm{PDA}(0,5 \mathrm{mg}, 0,031 \mathrm{~mol} \% \mathrm{Pd})$, aril-halogenid $(0,5 \mathrm{mmol})$, aril-boronsav $(0,55$ $\mathrm{mmol}), \mathrm{K}_{2} \mathrm{CO}_{3}(138 \mathrm{mg}, 1,0 \mathrm{mmol})$, és $\mathrm{EtOH}(96 \mathrm{~V} / \mathrm{V} \%)(2 \mathrm{ml})$ fiolába juttatása után a fiolát lezártuk, majd a reakcióelegyet szobahőmérsékleten, 3 órán át kevertettük. A rendszert $2 \mathrm{ml}$ EtOAc-al higítottuk, majd kevés szilikán átszürtük, a szilikát további $20 \mathrm{ml}$ EtOAc-al átmostuk. Az oldószert ezután rotációs vákuumbepárlóval eltávolítottuk, a nyers terméket oszlopkromatográfiával tisztítottuk, a terméket NMR spektroszkópiával jellemeztük.

\subsubsection{Tandem Suzuki reakció/transzfer hidrogénezés}

I. Módszer: Pd/PDA (10 mg, 0,62 mol\% Pd), aril-halogenid (0,5 mmol), aril-boronsav (0,55 mmol), $\mathrm{K}_{2} \mathrm{CO}_{3}$ (138 mg, 1,0 mmol), HCOONa (136 mg, 2,0 mmol), és EtOH (96 $\mathrm{V} / \mathrm{V} \%)(2 \mathrm{ml})$ fiolába juttatása után a fiolát lezártuk, majd a reakcióelegyet $80^{\circ} \mathrm{C}$-on, 1 órán át kevertettük.

II. Módszer: Pd/PDA (10 mg, 0,62 mol\% Pd), aril-halogenid (0,5 mmol), arilboronsav (0,55 mmol), $\mathrm{K}_{2} \mathrm{CO}_{3}(138 \mathrm{mg}, 1,0 \mathrm{mmol}), \mathrm{HCOONa}(136 \mathrm{mg}, 2,0 \mathrm{mmol})$, és EtOH (96 V/V\%) (2 ml) fiolába juttatása után a fiolát lezártuk, majd a reakcióelegyet szobahőmérsékleten 2 órán át, majd $80^{\circ} \mathrm{C}$-on, 1 órán át kevertettük.

III. Módszer: Pd/PDA (10 mg, 0,62 mol\% Pd), aril-halogenid (0,5 mmol), arilboronsav (0,55 mmol), $\mathrm{K}_{2} \mathrm{CO}_{3}(138 \mathrm{mg}, 1,0 \mathrm{mmol})$, és EtOH $(96 \mathrm{~V} / \mathrm{V} \%)(2 \mathrm{ml})$ fiolába juttatása után a fiolát lezártuk, majd a reakcióelegyet $80^{\circ} \mathrm{C}$-on, 2 órán át kevertettük. Ezt követően HCOONa-ot (136 mg, 2,0 mmol) adtunk a reakcióelegyhez, majd további 1 órán át $80^{\circ} \mathrm{C}$-on kevertettük.

A termékelegyek feldolgozása minhárom módszer esetén ugyanúgy történt: A rendszert $2 \mathrm{ml}$ EtOAc-al higítottuk, majd kevés szilikán átszürtük, a szilikát további $20 \mathrm{ml}$ 
EtOAc-al átmostuk. Az oldószert ezután rotációs vákuumbepárlóval eltávolítottuk, a nyers terméket oszlopkromatográfiával tisztítottuk, a terméket NMR spektroszkópiával jellemeztük.

\subsection{5. $P d / P D A / M N P$ katalizátor újrahasznosítása}

$\mathrm{Az}$ újrahasznosítási kísérletek során a Pd/PDA/MNP katalizátort transzfer hidrogénezésben, Heck reakcióban, Suzuki reakcióban, és tandem Suzuki reakció/transzfer hidrogénezési reakcióban a fentebb leírt eljárások szerint használtuk. A termékelegyek feldolgozása során a reakcióedény (fiola vagy lombik) aljára helyezett neodímium mágnes segítségével szeparáltuk a Pd/PDA/MNP katalizátort, az oldatot dekantáltuk, a katalizátort ezután EtOAc-al $(2 \mathrm{ml})$, vízzel $(2 \times 2 \mathrm{ml})$, végül $\mathrm{Et}_{2} \mathrm{O}$-rel $(2 \mathrm{ml})$ mostuk, levegőn, szobahőmérsékleten szárítottuk. Az így kezelt katalizátort egy következő reakcióban használtuk fel.

\subsubsection{Katalizátorszürési tesztreakciók}

Szürési kísérleteket a fentebb ismertetett reakciókörülmények között, a reakciók kezdeti szakaszában (kivétel a $80^{\circ} \mathrm{C}$-on végzett Suzuki reakció), $40 \%$ konverzió elérése előtt hajtottuk végre. A szürést a reakció hőmérsékletén, Büchner-tölcsér segítségével végeztük. Ezt követően a szürletet tovább kevertettük a reakció hőmérsékleten a feltüntetett ideig. A konverziót GC-MS analízissel követtük.

\subsubsection{Méretnövelési kísérletek}

Transzfer hidrogénezés: Pd/PDA (100 mg, 0,57 mol\% Pd), 4-nitro-etilbenzoát (1,00 g, 5,12 mmol), HCOONa (1,39 g, 20,48 mmol), és $96 \mathrm{~V} / \mathrm{V} \%$ EtOH (20 ml) visszafolyós hűtővel szerelt gömblombikba juttatása után az elegyet $85^{\circ} \mathrm{C}$-on, 3 órán át kevertettük. Ezután a lehütött rendszert $\mathrm{Et}_{2} \mathrm{O}$-rel $(30 \mathrm{ml})$ higítottuk, desztillált vízzel $(3 \times 20 \mathrm{ml})$, valamint telített $\mathrm{NaCl}$ oldattal $(20 \mathrm{ml})$ mostuk, $\mathrm{MgSO}_{4}$-on szárítottuk. Az oldószert ezután rotációs vákuumbepárlóval eltávolítottuk, a nyers terméket oszlopkromatográfiával tisztítottuk $\left(\mathrm{SiO}_{2}\right.$, hexán $\rightarrow$ hexán/EtOAc 5:1), a terméket NMR spektroszkópiával jellemeztük. Kitermelés: 744 $\mathrm{mg}, 88 \%$.

Heck reakció: Pd/PDA (100 mg, 0,57 mol\% Pd), 4-bróm-acetofenon (1,00 g, 5,02 mmol), etil-akrilát (660 $\mu 1,6,0 \mathrm{mmol}), \mathrm{Na}_{2} \mathrm{CO}_{3}$ (745 mg, 7,0 mmol), $n \mathrm{Bu}_{4} \mathrm{NCl}(350 \mathrm{mg}, 1,25$ mmol), és NMP $(10 \mathrm{ml})$ fiolába juttatása után a fiolát lezártuk, majd a reakcióelegyet $85^{\circ} \mathrm{C}$-on 24 órán át kevertettük. Ezután a lehütött rendszert $10 \mathrm{ml}$ EtOAc-al higítottuk, majd kevés 
szilikán átszürtük, a szilikát további $30 \mathrm{ml}$ EtOAc-al átmostuk. A szürletet desztillált vízzel (4 $\times 30 \mathrm{ml}$ ), és telített $\mathrm{NaCl}$ oldattal $(20 \mathrm{ml})$ mostuk, a szerves fázist $\mathrm{MgSO}_{4}$-on szárítottuk. $\mathrm{Az}$ oldószert ezután rotációs vákuumbepárlóval eltávolítottuk, a nyers terméket oszlopkromatográfiával tisztítottuk $\left(\mathrm{SiO}_{2}\right.$, hexán $\rightarrow$ hexán/EtOAc 9:1), a terméket NMR spektroszkópiával jellemeztük. Kitermelés: $883 \mathrm{mg}, 81 \%$.

Suzuki reakció: Pd/PDA (0,58 mg, 1,82 x 10² mol\% Pd), 1-bróm-4-nitrobenzol (2,00 $\mathrm{g}, 9,90 \mathrm{mmol}$ ), fenil-boronsav (1,33 g, 10,90 mmol), $\mathrm{K}_{2} \mathrm{CO}_{3}$ (2,74 g, 19,8 mmol), és 96 V/V\% EtOH $(40 \mathrm{ml})$ visszafolyós hủtővel szerelt gömblombikba juttatása után a reakcióelegyet $80^{\circ} \mathrm{C}$-on, 30 percen át kevertettük. A termékelegyet desztillált vízzel $(50 \mathrm{ml})$ higítottuk, és EtOAc-al $(2 \times 30 \mathrm{ml})$ extraháltuk, majd a szerves fázist telített $\mathrm{NaCl}$ oldattal mostuk, és $\mathrm{MgSO}_{4}$-on szárítottuk. Az oldószert ezután rotációs vákuumbepárlóval eltávolítottuk, a nyers terméket oszlopkromatográfiával tisztítottuk $\left(\mathrm{SiO}_{2}\right.$, hexán $\rightarrow$ hexán/EtOAc 9:1), a terméket NMR spektroszkópiával jellemeztük. Kitermelés: 1,81 g, $92 \%$.

Tandem Suzuki reakció/transzfer hidrogénezés: Pd/PDA (100mg, 0,62 mol\% Pd), 1bróm-4-nitrobenzol (1 g, 4,95 mmol), fenil-boronsav (664 mg, 5,45 mmol), $\mathrm{K}_{2} \mathrm{CO}_{3}(1,368 \mathrm{~g}$, $10,67 \mathrm{mmol}), \mathrm{HCOONa}(1,35 \mathrm{mg}, 19,80 \mathrm{mmol})$, és $96 \mathrm{~V} / \mathrm{V} \% \mathrm{EtOH}(20 \mathrm{ml})$ visszafolyós hűtővel szerelt gömblombikba juttatása után a reakcióelegyet $80^{\circ} \mathrm{C}$-on, 60 percen át kevertettük. A termékelegyet desztillált vízzel $(50 \mathrm{ml})$ higítottuk, és EtOAc-al $(2$ x $30 \mathrm{ml})$ extraháltuk, majd a szerves fázist telített $\mathrm{NaCl}$ oldattal mostuk, és $\mathrm{MgSO}_{4}$-on szárítottuk. $\mathrm{Az}$ oldószert ezután rotációs vákuumbepárlóval eltávolítottuk, a nyers terméket oszlopkromatográfiával tisztítottuk $\left(\mathrm{SiO}_{2}\right.$, hexán $\rightarrow$ hexán/EtOAc 5:1), a terméket NMR spektroszkópiával jellemeztük. Kitermelés: 732 mg, 87 \%.

\subsection{Azobenzol-származékok szintézise}

\section{4-hidroxi-azobenzol (azofenol, 65)}

Telített sósav oldat $(50 \mathrm{ml})$ és víz $(250 \mathrm{ml})$ elegyében anilint $(14,7 \mathrm{ml}, 161 \mathrm{mmol})$ oldottunk fel, majd jeges-vizes fürdő segítségével $0^{\circ} \mathrm{C}$-ra hütve $\mathrm{NaNO}_{2}(12,2 \mathrm{~g}, 176,8 \mathrm{mmol})$ vízzel $(75 \mathrm{ml})$ készült oldatát csepegtettük bele olyan sebességgel, hogy a reakcióelegy hőmérséklete ne haladja meg az $5^{\circ} \mathrm{C}$-ot. Ezután $0-5^{\circ} \mathrm{C}$ között tartva a hőmérsékletet még 15 percig kevertettük a rendszert, majd fenol $(15,15 \mathrm{~g}, 161,0 \mathrm{mmol})$ EtOH-os $(50 \mathrm{ml})$ oldatát lassan hozzáadagoltuk, és további 1 órán át kevertettük jeges-vizes hütést alkalmazva. A reakcióidő lejárta után a $\mathrm{pH}$-t $\mathrm{NaHCO}_{3}$-oldat segítségével 7-re állítottuk, majd 
szobahőmérsékleten fél órán át kevertettük a csapadékos rendszert. Ezt követően a vörös csapadékot szürtük, vízzel (kb. $30 \mathrm{ml})$ mostuk, vákkumban szárítottuk. A nyers terméket oszlopkromatográfiával tisztítottuk $\left(\mathrm{SiO}_{2}\right.$, hexán/EtOAc 9:1). Kitermelés: $26,2 \mathrm{~g}, 82 \% .{ }^{1} \mathrm{H}$ NMR (500 MHz, DMSO- $\left.d_{6}\right) \delta=10.27(\mathrm{~s}, 1 \mathrm{H}), 7.81(\mathrm{dd}, J=8.1,3.3 \mathrm{~Hz}, 4 \mathrm{H}), 7.55$ (t, $J=7.5$ $\mathrm{Hz}, 2 \mathrm{H}), 7.49$ (t, $J=7.2 \mathrm{~Hz}, 1 \mathrm{H}), 6.95(\mathrm{~d}, J=8.7 \mathrm{~Hz}, 2 \mathrm{H}) \mathrm{ppm} ;{ }^{13} \mathrm{C}$ NMR (126 MHz, DMSO$\left.d_{6}\right) \delta=160.90,152.07,145.19,130.38,129.25,124.77,122.03,115.88$ ppm. HRMS (ESI+) $\mathrm{m} / \mathrm{z}=199.0870 ;$ számított: $199.0871 ;[\mathrm{M}+\mathrm{H}]^{+}$.

\section{1-(4-(3-bromopropoxi)fenil)-2-fenildiazén (66)}

65 (300 mg, 1,50 mmol), $\mathrm{K}_{2} \mathrm{CO}_{3}(628 \mathrm{mg}, 4,54 \mathrm{mmol})$, és 1,3-dibróm-propán (772 $\mu 1$, $7,57 \mathrm{mmol})$, és aceton $(20 \mathrm{ml})$ fiolába juttatása után a reakcióelegyet nitrogén atmoszféra alatt $60^{\circ} \mathrm{C}$-on 18 órán át kevertettük. Ezután a lehütött rendszert $10 \mathrm{ml}$ EtOAc-al higítottuk, majd kevés szilikán átszürtük, a szilikát további $30 \mathrm{ml}$ EtOAc-al átmostuk. Az oldószert rotációs vákuumbepárlóval eltávolítottuk, a nyers terméket oszlopkromatográfiával tisztítottuk $\left(\mathrm{SiO}_{2}\right.$, hexán $\rightarrow$ hexán/EtOAc 9:1), a terméket NMR spektroszkópiával jellemeztük. Kitermelés: 419 mg, $87 \%$. ${ }^{1} \mathrm{H}$ NMR (500 MHz, $\left.\mathrm{CDCl}_{3}\right) \delta=7.90(\mathrm{dd}, J=20.7,8.2 \mathrm{~Hz}, 4 \mathrm{H}), 7.50(\mathrm{t}, J=7.6$ $\mathrm{Hz}, 2 \mathrm{H}), 7.44(\mathrm{t}, J=7.2 \mathrm{~Hz}, 1 \mathrm{H}), 7.02(\mathrm{~d}, J=8.9 \mathrm{~Hz}, 2 \mathrm{H}), 4.19(\mathrm{t}, J=5.8 \mathrm{~Hz}, 2 \mathrm{H}), 3.62(\mathrm{t}, J$ $=6.4 \mathrm{~Hz}, 2 \mathrm{H}), 2.36(\mathrm{p}, J=6.1 \mathrm{~Hz}, 2 \mathrm{H}) \mathrm{ppm} ;{ }^{13} \mathrm{C} \mathrm{NMR}\left(126 \mathrm{MHz}, \mathrm{CDCl}_{3}\right) \delta=161.28$, $152.93,147.33,130.53,129.16,124.90,122.72,114.90,65.82,32.43,29.87$ ppm. HRMS (ESI+) $m / z=319.0447$; számított: 319.0446; [M + H $]^{+}$.

\section{3-(4-(fenildiazenil)fenoxi)propán-1-tiol $\left(\mathrm{AzoC}_{3} \mathrm{SH}\right)$}

66-ot (575 mg, 1,80 mmol) feloldottuk EtOH-ban (10 ml), majd hozzáadtuk $\mathrm{Na}_{2} \mathrm{~S}_{2} \mathrm{O}_{3}$ $\times 5 \mathrm{H}_{2} \mathrm{O}(670 \mathrm{mg}, 2,7 \mathrm{mmol})$ vízzel készült oldatát $(3 \mathrm{ml})$. Az elegyet nitrogen atmoszféra alatt $80^{\circ} \mathrm{C}$-on, 6 órán át kevertettük. Ezt követően $0^{\circ} \mathrm{C}$-ra hütve a termékelegyet, a sárga csapadékot leszürtük, és további tisztítás nélkül feloldottuk $\mathrm{CHCl}_{3}(6 \mathrm{ml})$ és $\mathrm{HCl}$ oldat $(6 \mathrm{ml}$, $1 \mathrm{M})$ kétfázisú keverékében. A rendszert nitrogén gázzal 5 percig átbuborékoltattuk, majd $60^{\circ} \mathrm{C}$-on, 14 órán át erőteljesen kevertettük. Ezt követően a szerves fázist elválesztottuk, a vizest $\mathrm{CHCl}_{3}$-al $(20 \mathrm{ml})$ extraháltuk, az egyesített szerves fázisokat vízzel $(10 \mathrm{ml})$, valamint telített $\mathrm{NaCl}$ oldattal $(10 \mathrm{ml})$ mostuk, $\mathrm{MgSO}_{4}$-on szárítottuk. Az oldószert rotációs vákuumbepárlóval eltávolítva, tiszta termékhez jutottunk. Kitermelés: $217 \mathrm{mg}, 44 \%$ ). ${ }^{1} \mathrm{H}$ NMR (500 MHz, $\left.\mathrm{CDCl}_{3}\right) \delta=7.91(\mathrm{dd}, J=19.7,8.2 \mathrm{~Hz}, 4 \mathrm{H}), 7.50(\mathrm{t}, J=7.5 \mathrm{~Hz}, 2 \mathrm{H}), 7.44(\mathrm{t}$, $J=7.1 \mathrm{~Hz}, 1 \mathrm{H}), 7.02(\mathrm{~d}, J=8.7 \mathrm{~Hz}, 2 \mathrm{H}), 4.17(\mathrm{t}, J=5.9 \mathrm{~Hz}, 2 \mathrm{H}), 2.77(\mathrm{q}, J=7.2 \mathrm{~Hz}, 2 \mathrm{H})$, $2.18-2.04(\mathrm{~m}, 2 \mathrm{H}), 1.42(\mathrm{t}, J=8.0 \mathrm{~Hz}, 1 \mathrm{H}) \mathrm{ppm} ;{ }^{13} \mathrm{C} \mathrm{NMR}\left(126 \mathrm{MHz}, \mathrm{CDCl}_{3}\right) \delta=161.48$, 
$152.91,147.23,130.50,129.16,124.92,122.71,114.87,66.15,33.39,21.32$ ppm. HRMS (ESI+) $m / z=273.1065$; számított: 273.1062; $[\mathrm{M}+\mathrm{H}]^{+}$.

\section{1-(4-(6-bromohexiloxi)fenil)-2-fenildiazén (67)}

65 (500 mg, 2,52 mmol), $\mathrm{K}_{2} \mathrm{CO}_{3}(628 \mathrm{mg}, 4,54 \mathrm{mmol})$, és 1,6-dibróm-hexán (1,55 ml, 12,61 mmol), és aceton $(20 \mathrm{ml})$ fiolába juttatása után a reakcióelegyet nitrogén atmoszféra alatt $60^{\circ} \mathrm{C}$-on 18 órán át kevertettük. Ezután a lehütött rendszert $10 \mathrm{ml}$ EtOAc-al higítottuk, majd kevés szilikán átszürtük, a szilikát további $30 \mathrm{ml}$ EtOAc-al átmostuk. Az oldószert rotációs vákuumbepárlóval eltávolítottuk, a nyers terméket oszlopkromatográfiával tisztítottuk $\left(\mathrm{SiO}_{2}\right.$, hexán $\rightarrow$ hexán/EtOAc 9:1), a terméket NMR spektroszkópiával jellemeztük. Kitermelés: $519 \mathrm{mg}, 57 \%$. ${ }^{1} \mathrm{H}$ NMR $\left(300 \mathrm{MHz}, \mathrm{CDCl}_{3}\right) \delta=7.97-7.82(\mathrm{~m}, 4 \mathrm{H})$, $7.53-7.41(\mathrm{~m}, 3 \mathrm{H}), 7.00(\mathrm{~d}, J=8.9 \mathrm{~Hz}, 2 \mathrm{H}), 4.05(\mathrm{t}, J=6.3 \mathrm{~Hz}, 2 \mathrm{H}), 3.44(\mathrm{t}, J=6.8 \mathrm{~Hz}$,

$2 \mathrm{H}), 1.88(\mathrm{dd}, J=14.1,6.8 \mathrm{~Hz}, 4 \mathrm{H}), 1.54(\mathrm{~s}, 4 \mathrm{H}) \mathrm{ppm} ;{ }^{13} \mathrm{C} \mathrm{NMR}\left(75 \mathrm{MHz}, \mathrm{CDCl}_{3}\right) \delta=$ 161.72 , 152.93, 147.06, 130.45, 129.15, 124.89, 122.67, 114.82, 68.21, 33.89, 32.80, 29.17, 28.06, 25.42 ppm. HRMS (ESI+) $m / z=361.0923$; számított: 361.0915; [M+ H] .

\section{6-(4-(fenildiazenil)fenoxi)hexán-1-tiol (AzoC $6 \mathrm{SH})$}

67-et (845 mg, 2,34 mmol) feloldottuk EtOH-ban (10 ml), majd hozzáadtuk $\mathrm{Na}_{2} \mathrm{~S}_{2} \mathrm{O}_{3} \mathrm{x}$ $5 \mathrm{H}_{2} \mathrm{O}(640 \mathrm{mg}, 2,57 \mathrm{mmol})$ vízzel készült oldatát $(2,5 \mathrm{ml})$. Az elegyet nitrogen atmoszféra alatt $80^{\circ} \mathrm{C}$-on, 2 órán át kevertettük. Ezt követően $0^{\circ} \mathrm{C}$-ra hütve a termékelegyet, a sárga csapadékot leszürtük, és további tisztítás nélkül feloldottuk $\mathrm{CHCl}_{3}(10 \mathrm{ml})$ és $\mathrm{HCl}$ oldat (10 ml, 1M) kétfázisú keverékében. A rendszert nitrogén gázzal 5 percig átbuborékoltattuk, majd $60^{\circ} \mathrm{C}$-on, 18 órán át erőteljesen kevertettük. Ezt követően a szerves fázist elválesztottuk, a vizest $\mathrm{CHCl}_{3}$-al $(20 \mathrm{ml})$ extraháltuk, az egyesített szerves fázisokat vízzel $(10 \mathrm{ml})$, valamint telített $\mathrm{NaCl}$ oldattal $(10 \mathrm{ml})$ mostuk, $\mathrm{MgSO}_{4}$-on szárítottuk. Az oldószert rotációs vákuumbepárlóval eltávolítva, tiszta termékhez jutottunk. Kitermelés: $588 \mathrm{mg}, 80 \% .{ }^{1} \mathrm{H}$ NMR (500 MHz, $\left.\mathrm{CDCl}_{3}\right) \delta=7.95-7.84(\mathrm{~m}, 4 \mathrm{H}), 7.50(\mathrm{t}, J=7.5 \mathrm{~Hz}, 2 \mathrm{H}), 7.45-7.41$ (m, 1H), $7.03-6.97(\mathrm{~m}, 2 \mathrm{H}), 4.05(\mathrm{t}, J=6.4 \mathrm{~Hz}, 2 \mathrm{H}), 2.56(\mathrm{dd}, J=14.6,7.4 \mathrm{~Hz}, 2 \mathrm{H}), 1.87-1.79$ $(\mathrm{m}, 2 \mathrm{H}), 1.71-1.62(\mathrm{~m}, 2 \mathrm{H}), 1.55-1.45(\mathrm{~m}, 4 \mathrm{H}), 1.35(\mathrm{t}, J=7.7 \mathrm{~Hz}, 1 \mathrm{H}) \mathrm{ppm} ;{ }^{13} \mathrm{C} \mathrm{NMR}$ $\left(126 \mathrm{MHz}, \mathrm{CDCl}_{3}\right) \delta=161.78,152.97,147.09,130.43,129.15,124.89,122.68,114.85$, 68.32, 34.03, 29.24, 28.22, 25.70, 24.68 ppm. HRMS (ESI+) $\mathrm{m} / z=315.1534$; számított: 315.1531; $[\mathrm{M}+\mathrm{H}]^{+}$. 


\section{6-(4-(fenildiazenil)fenoxi)hexán-1-amin $\left(\mathrm{AzoC}_{6} \mathrm{NH}_{2}\right)$}

67-et (300 mg, 0,83 mmol), $\mathrm{NaN}_{3}(108 \mathrm{mg}, 1,66 \mathrm{mmol})$, és DMF (20 ml) fiolába juttatása után a reakcióelegyet nitrogen atmoszféra alatt, szobahőmérsékleten, 24 órán át kevertettük. Ezután az elegyet desztillált vízzel $(100 \mathrm{ml})$ higítottuk, EtOAc-al $(2 \mathrm{x} 30 \mathrm{ml})$ extraháltuk. Az egyesített szerves fázisokat desztillált vízzel ( 3 x $30 \mathrm{ml})$, telített $\mathrm{NaCl}$ oldattal $(20 \mathrm{ml})$ mostuk, $\mathrm{MgSO}_{4}$-on szárítottuk. Az oldószert rotációs vákuumbepárlóval eltávolítva, a nyers terméket száraz $\mathrm{Et}_{2} \mathrm{O}$-ben $(20 \mathrm{ml})$ feloldottuk, majd kis részletekben $\mathrm{LiAlH}_{4}$-et $(63 \mathrm{mg}$, $1,66 \mathrm{mmol}$ ) adagoltunk hozzá nitrogén atmoszféra alatt, szobahőmérsékleten. A redukálószer beadagolása után az elegyet 30 percig kevertettük, majd vízzel telített $\mathrm{Et}_{2} \mathrm{O}(20 \mathrm{ml})$ hozzáadagolásával elreagáltattuk a maradék $\mathrm{LiAlH}_{4}$-et. A termékelegyet desztillált vízzel (30 $\mathrm{ml}$ ), és telített $\mathrm{NaCl}$ oldattal $(20 \mathrm{ml})$ mostuk, a szerves fázist $\mathrm{MgSO}_{4}$-on szárítottuk. $\mathrm{Az}$ oldószert ezután rotációs vákuumbepárlóval eltávolítottuk, a nyers terméket oszlopkromatográfiával tisztítottuk $\left(\mathrm{SiO}_{2}\right.$, hexán $\rightarrow$ hexán/EtOAc 5:1), a terméket NMR spektroszkópiával jellemeztük. Kitermelés: $175 \mathrm{mg}, 71 \%$. ${ }^{1} \mathrm{H}$ NMR $\left(300 \mathrm{MHz}, \mathrm{CDCl}_{3}\right) \delta=$ $7.89(\mathrm{dd}, J=11.3,8.1 \mathrm{~Hz}, 4 \mathrm{H}), 7.52-7.40(\mathrm{~m}, 3 \mathrm{H}), 7.00(\mathrm{~d}, J=8.9 \mathrm{~Hz}, 2 \mathrm{H}), 4.04(\mathrm{t}, J=6.5$ $\mathrm{Hz}, 2 \mathrm{H}), 2.71(\mathrm{t}, J=6.6 \mathrm{~Hz}, 2 \mathrm{H}), 1.91-1.76(\mathrm{~m}, 2 \mathrm{H}), 1.54-1.41(\mathrm{~m}, 6 \mathrm{H}), 1.29$ (s, 2H) ppm; ${ }^{13} \mathrm{C}$ NMR $\left(126 \mathrm{MHz}, \mathrm{CDCl}_{3}\right) \delta=161.82,152.98,147.07,130.42,129.15,124.88,122.68$, 114.86, 68.41, 42.32, 33.91, 29.34, 26.82, 26.09 ppm. HRMS (ESI+) $\mathrm{m} / z=298.1919$; számított: 298.1919; [M + H $]^{+}$.

\section{4-Hidroxi-4'-dimetilamino-azobenzol (70)}

4-Aminofenolt (500 mg, 4,58 mmol) feloldottunk absz. EtOH (12 ml) és telített sósavoldat (1,2 ml, 13,75 mmol) keverékében. Az elegyet jeges-vizes hütés segítségével 0 $5^{\circ} \mathrm{C}$-ra hütöttük, majd izoamil-nitritet $(616 \mu 1,4,58 \mathrm{mmol})$ csepegtettünk bele folyamatos kevertetés közben. Ezt követően további 15 percen át kevertettük $0-5^{\circ} \mathrm{C}$-on a reakcióelegyet, majd jéghideg $\mathrm{Et}_{2} \mathrm{O}$-re $(30 \mathrm{ml})$ öntöttük. A diazónium-só szürke kristályok formájában, 5 perc alatt csapódott ki, amit szüréssel eltávolítottunk, kevés jéghideg $\mathrm{Et}_{2} \mathrm{O}$-rel mostunk, majd $\mathrm{N}, \mathrm{N}$ dimetil-anilin $(581 \mu 1,4,58 \mathrm{mmol})$ absz. EtOH-os $(25 \mathrm{ml})$ oldátához adagoltuk $0^{\circ} \mathrm{C}$-on. Ezután a reakcióelegyet 1 órán át $0-5^{\circ} \mathrm{C}$ körüli hőmérsékleten, majd szobahőmérsékleten további 1 órán át kevertettük. A reakcióidő letelte után az oldószert rotációs vákuumbepárlóval eltávolítottuk, és a maradékot EtOAc-ban $(30 \mathrm{ml})$ feloldottuk. Az elegyet citromsav vizes oldatával $(20 \mathrm{ml}, 10 \mathrm{~m} / \mathrm{m} \%)$, valamint telített $\mathrm{NaCl}$ oldattal $(20 \mathrm{ml})$ mostuk, $\mathrm{MgSO}_{4}$-on szárítottuk. Az oldószert végül rotációs vákuumbepárlóval eltávolítottuk, a nyers 
terméket oszlopkromatográfiával tisztítottuk $\left(\mathrm{SiO}_{2}\right.$, hexán $\rightarrow$ hexán/EtOAc 5:1), a terméket NMR spektroszkópiával jellemeztük. Kitermelés: $373 \mathrm{mg}, 34 \%$. ${ }^{1} \mathrm{H}$ NMR $(500 \mathrm{MHz}$, DMSO- $\left.d_{6}\right) \delta=9.98(\mathrm{~s}, 1 \mathrm{H}), 7.70(\mathrm{dd}, J=20.2,8.9 \mathrm{~Hz}, 4 \mathrm{H}), 6.89(\mathrm{~d}, J=8.8 \mathrm{~Hz}, 2 \mathrm{H}), 6.80$ (d, $J=9.1 \mathrm{~Hz}, 2 \mathrm{H}), 3.02(\mathrm{~s}, 6 \mathrm{H}) \mathrm{ppm} ;{ }^{13} \mathrm{C} \mathrm{NMR}\left(126 \mathrm{MHz}, \mathrm{DMSO}-d_{6}\right) \delta=159.27,151.81$, $145.55,142.65,123.93,123.66,115.66,111.56 \mathrm{ppm}$. HRMS $(\mathrm{ESI}+) \mathrm{m} / \mathrm{z}=242.1290$; számított: 242.1293; [M + H $]^{+}$.

\section{4-(6-bromohexil-1-oxi)-4'-(N,N-dimetilamino)azobenzol (71)}

70 (400 mg, 1,66 mmol), $\mathrm{K}_{2} \mathrm{CO}_{3}(687 \mathrm{mg}, 4,97 \mathrm{mmol})$, és 1,6-dibróm-hexán (1,28 ml, $8,29 \mathrm{mmol})$, és aceton $(20 \mathrm{ml})$ fiolába juttatása után a reakcióelegyet nitrogén atmoszféra alatt $60^{\circ} \mathrm{C}$-on 18 órán át kevertettük. Ezután a lehütött rendszert $10 \mathrm{ml}$ EtOAc-al higítottuk, majd kevés szilikán átszürtük, a szilikát további $30 \mathrm{ml}$ EtOAc-al átmostuk. Az oldószert rotációs vákuumbepárlóval eltávolítottuk, a nyers terméket oszlopkromatográfiával tisztítottuk $\left(\mathrm{SiO}_{2}\right.$, hexán $\rightarrow$ hexán/EtOAc 7:1), a terméket NMR spektroszkópiával jellemeztük. Kitermelés: 492 mg, $73 \% .{ }^{1} \mathrm{H}$ NMR $\left(300 \mathrm{MHz}, \mathrm{CDCl}_{3}\right) \delta=7.83(\mathrm{dd}, J=8.5,4.9 \mathrm{~Hz}, 4 \mathrm{H}), 6.97(\mathrm{~d}, J=8.8 \mathrm{~Hz}$, 2H), $6.76(\mathrm{~d}, J=8.8 \mathrm{~Hz}, 2 \mathrm{H}), 4.03(\mathrm{t}, J=6.4 \mathrm{~Hz}, 2 \mathrm{H}), 3.43(\mathrm{t}, J=6.7 \mathrm{~Hz}, 2 \mathrm{H}), 3.07$ (s, 6H), $1.98-1.74(\mathrm{~m}, 4 \mathrm{H}), 1.53(\mathrm{~s}, 4 \mathrm{H}) \mathrm{ppm} ;{ }^{13} \mathrm{C} \mathrm{NMR}\left(126 \mathrm{MHz}, \mathrm{CDCl}_{3}\right) \delta=160.53,152.18$, 143.94, 124.67, 123.98, 114.78, 111.84, 68.16, 40.52, 33.87, 32.85, 29.24, 28.09, 25.46 ppm. HRMS (ESI+) $m / z=404.1334$; számított: 404.1337; [M + H $]^{+}$.

\section{4-(6-merkaptohexil-1-oxi)-4'-(dimetilamino)azobenzol ( $\left.\mathrm{Me}_{2} \mathrm{NAzoC} 6 \mathrm{SH}\right)$}

71 (300 mg, 0,74 mmol), tiokarbamid (113 mg, 1,48 mmol), és absz. EtOH (40 ml) fiolába juttatása után a reakcióelegyet nitrogén atmoszféra alatt $80^{\circ} \mathrm{C}$-on, 24 órán át kevertettük. A reakcióidő letelte után az elegyet lehütöttük szobahőmérsékletre, majd rotációs vákuumbepárló segítségével $10 \mathrm{ml-re}$ csökkentettük a rendszer térfogatát. A maradékot pentánnal (20 ml) higítottuk, a kivált csapadékot leszürtük. Az így nyert tiourónium-sót (269 mg, $76 \%)$ absz. EtOH-ban $(12 \mathrm{ml})$ feloldottuk, és $\mathrm{NaOH}(23 \mathrm{mg})$ vizes oldatát $(2 \mathrm{ml})$ hozzáadva a reakcióelegyet nitrogén gázzal 5 percig átbuborékoltattuk, majd $80^{\circ} \mathrm{C}$-on 3 órán át kevertettük. A lehült reakcióelegyről ezután eltávolítottuk az oldószert, majd $\mathrm{CHCl}_{3}$-ban (30 ml) feloldva mostuk vízzel $(20 \mathrm{ml})$, és telített $\mathrm{NaCl}$ oldattal $(20 \mathrm{ml})$, végül $\mathrm{MgSO}_{4}$-on szárítottuk. Az oldószert rotációs vákuumbepárlóval eltávolítva, a nyers terméket oszlopkromatográfiával tisztítottuk $\left(\mathrm{SiO}_{2}\right.$, hexán $\rightarrow$ hexán/EtOAc 7:1), a terméket NMR spektroszkópiával jellemeztük. Kitermelés: $184 \mathrm{mg}, 69 \%$. ${ }^{1} \mathrm{H} \mathrm{NMR}\left(500 \mathrm{MHz}, \mathrm{CDCl}_{3}\right) \delta=$ $7.83(\mathrm{t}, J=8.6 \mathrm{~Hz}, 4 \mathrm{H}), 6.97(\mathrm{~d}, J=9.0 \mathrm{~Hz}, 2 \mathrm{H}), 6.76(\mathrm{~d}, J=9.1 \mathrm{~Hz}, 2 \mathrm{H}), 4.03(\mathrm{t}, J=6.5 \mathrm{~Hz}$, 
2H), $3.07(\mathrm{~s}, 6 \mathrm{H}), 2.55(\mathrm{dd}, J=14.6,7.5 \mathrm{~Hz}, 2 \mathrm{H}), 1.88-1.76(\mathrm{~m}, 2 \mathrm{H}), 1.73-1.59(\mathrm{~m}, 2 \mathrm{H})$, $1.55-1.44(\mathrm{~m}, 4 \mathrm{H}), 1.34(\mathrm{t}, J=7.7 \mathrm{~Hz}, 1 \mathrm{H}) \mathrm{ppm} ;{ }^{13} \mathrm{C}$ NMR $\left(126 \mathrm{MHz}, \mathrm{CDCl}_{3}\right) \delta=160.55$, $152.18,147.55,143.94,124.63,123.98,114.78,111.79$, 68.24, 40.50, 34.06, 29.30, 28.26, 25.73, 24.70 ppm. HRMS (ESI+) $m / z=358.1953$; számított: 358.1953; [M + H $]^{+}$.

\subsection{Határfelületek előállítása és módosítása}

\subsubsection{Q-PDA-Au elöállítása}

Polimerizáció előtt a kvarc lapokat forró $\mathrm{H}_{2} \mathrm{SO}_{4} / \mathrm{H}_{2} \mathrm{O}_{2}$ 1:1 arányú keverékével mostuk (Au szennyeződés esetén ezt megelőzően királyvízzel is) 15 percig. A megtisztított kvarc lapokat ( $8 \mathrm{db}, 10 \times 20 \mathrm{~mm}$ ) Tris bázis (148 mg, 1,22 mmol) és Tris-hidroklorid (75 mg, 0,48 mmol) vízzel $(150 \mathrm{ml})$ készült puffer-oldatába merítettük, melyet oxigénnel 10 percig átbuborékoltattunk. Dopamin-hidroklorid $(340 \mathrm{mg}, 1,79 \mathrm{mmol})$ vizes oldatát $(50 \mathrm{ml})$ hozzáadva szobahőmérsékleten, 24 órán át enyhén kevertettük a rendszert. A reakcióidő letelte után a lemezeket desztillált vízzel, valamint MeCN-lel mostuk, ultrahangos kádban (MeCN-ben) tisztítottuk, levegőn szárítottuk. Az így elkészített Q-PDA lemezt $\mathrm{AuCl}_{3} \times 3 \mathrm{H}_{2} \mathrm{O}$ $(250 \mu \mathrm{g} / \mathrm{ml}, 10 \mathrm{ml})$ vizes oldatába merítettük szobahőmérsékleten, 3 órára. Végül, a Q-PDAAu lemezeket vízzel, valamint MeCN-lel mostuk, levegőn szárítottuk.

\subsubsection{Q-PDA-Au módosítása azobenzol származékokkal}

Az előállított Q-PDA-Au lemezt belemerítettük a megfelelő azobenzol származék lezárható fiolában lévő EtOH-os $(10 \mathrm{ml}, 1 \mathrm{M})$ oldatába, majd $40^{\circ} \mathrm{C}$-on, 24 órán át, kevertetés nélkül tartottuk. Ezt követően a rendszert szobahőmérsékletre hütöttük, a lemezt mostuk EtOH-lal $(10 \mathrm{ml})$, MeCN-lel $(10 \mathrm{ml})$, és levegőn szárítottuk. Az elkészült felületet spektrofotometriás vizsgálatoknak, és kontaktszög méréseknek vetettük alá.

\subsubsection{Ligandumcsere Q-PDA-Au felületen}

A megfelelő ligandummal módosított Q-PDA-Au lemezt belemerítettük a cserélő ligandum EtOH-os $(10 \mathrm{ml}, 1 \mathrm{M})$ oldatába, majd $40^{\circ} \mathrm{C}$-on, 24 órán át (vagy a feltüntetett ideig), kevertetés nélkül tartottuk. Ezt követően a rendszert szobahőmérsékletre hütöttük, a lemezt mostuk EtOH-lal $(10 \mathrm{ml})$, MeCN-lel $(10 \mathrm{ml})$, és levegőn szárítottuk. Az elkészült felületet spektrofotometriás vizsgálatoknak, és kontaktszög méréseknek vetettük alá. 


\section{8. Összefoglalás}

A dopamin vizes közegben, szobahőmérsékleten végbemenő autopolimerizációjának, univerzális adhezivitásának, és reduktív sajátságának köszönhetően, valamint a zöld kémia igényeit kielégítve állítottunk elő polidopamin (PDA) hordozós katalizátorokat, és fotoizomerizálható határfelületeket.

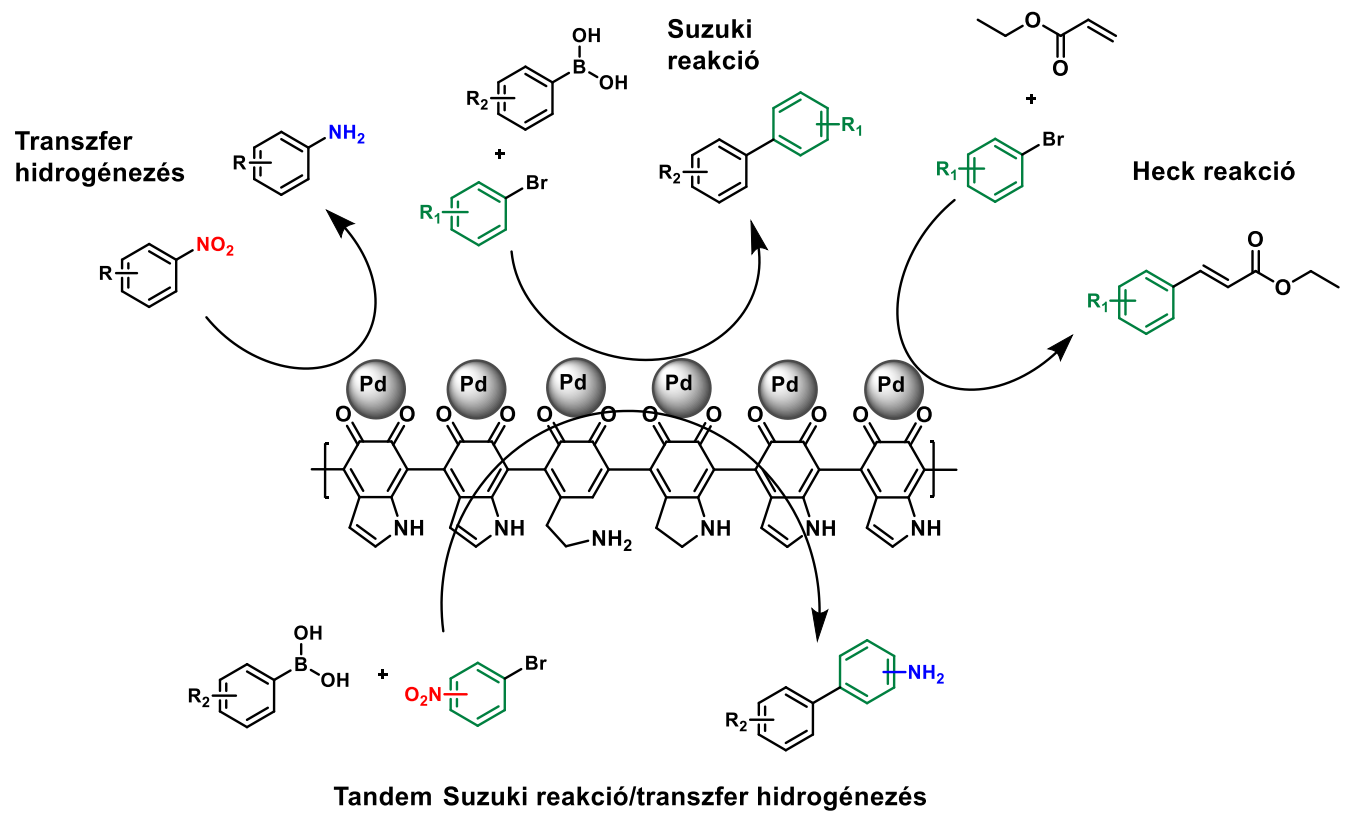

I. ábra Pd/PDA katalizátorral megvalósított reakciók.

A PDA tömbpolimerizációja során nyert polimer részecskék felületén $\operatorname{Pd}(\mathrm{OAc})_{2}$ metanolos oldatából rendkívül kis átmérőjü $(1-3 \mathrm{~nm})$, és kiemelkedő katalitikus aktivitással rendelkező Pd nanorészecskéket hoztunk létre (Pd/PDA), és sikeresen alkalmaztuk több, különböző katalitikus átalakításban (I. ábra). Nitroaril vegyületek katalitikus transzfer hidrogénezése során magas hozammal, nagy funkcióscsoport tolerancia mellett tudtunk előállítani anilin származékokat. Mindez gyorsan (60 perc), stabil hidrogénforrás mellett (HCOONa), megújuló forrásból származó oldószer (96 V/V\% EtOH) jelenlétében kivitelezhető volt. Ezzel szemben, karbonil vegyületek redukciója már kevésbé bizonyult széleskörünek, csak acetofenon származékok redukciója játszódott le a megfelelő alkohollá. Általánosan elmondható, hogy az aldehid funkcióval rendelkező molekulák nem kompatibilisek a PDA hordozós rendszerünkkel, ugyanis vélhetően a polimer aminocsoportjaival imint képezve gátolták a katalízist. Aril-halogenidek és etil-akrilát Heck 
reakciójában is aktív katalizátornak bizonyult a Pd/PDA. Kiemelkedő katalitikus aktivitást tapasztaltunk aril-boronsavak aril-halogenidekkel történő Suzuki reakciójában, ahol $80^{\circ} \mathrm{C}$-on több esetben is 5 perc alatt teljes konverziót detektáltunk, ezen kívül szobahőmérsékleten végezve a reakciókat 2 - 3 óra elegendő volt magas hozamok eléréséhez. Lecsökkentve a Pd mennyiségét 18 ppm-re $\left(1,8 \times 10^{-3} \mathrm{~mol} \%\right), 80^{\circ} \mathrm{C}$-on csupán 30 percre kellett növelnünk a reakcióidőt, hogy teljes konverzió mellett, magas kitermeléssel megkapjuk fenilboronsav 4bróm-nitrobenzollal Suzuki-kapcsolt termékét grammos mennyiségben. Úgy gondoljuk, hogy ezt a kimagasló aktivitást az apró átmérőjü Pd nanorészecskéknek köszönhetjük. Kihasználva a gyors Suzuki reakciót, és a felismerést, hogy ugyanabban az oldószerben (96 V/V\% EtOH), ugyanazzal a katalizátorral kivitelezhető, mint a transzfer hidrogénezés, összekapcsoltuk a két reakciólépést egy egyedényes, tandem folyamattá. A tandem Suzuki reakció/transzfer hidrogénezésben magas hozammal tudtunk előállítani aril-boronsavak és nitroaril-bromidok reakciójával amino-bifenileket. Amennyiben kisebb reakciósebességü Suzuki reakció történt a redukciós lépéssel párhuzamosan, romló szelektivitásokat tapasztaltunk, így egy második módszert dolgoztunk ki a reakcióelegy felfütési programjának módosításával. Heteroarilbromidok egyedényes Suzuki reakció/transzfer hidrogénezését is megvalósítottuk 3-nitrofenilboronsavval, azonban ekkor a hidrogénforrást ( $\mathrm{HCOONa}$ ) a Suzuki lépés után kellett a reakcióelegyhez adnunk, hogy elkelrüljük a melléktermékek képződését.

Előállítottuk a Pd/PDA katalizátorunk magnetit magon rögzített megfelelőjét (Pd/PDA/MNP), hogy megkönnyítsük a katalizátor újrahasznosítását, azonban valamelyest nagyobb, $5-8 \mathrm{~nm}$ átmérőjü Pd nanorészecskéket kaptunk a katalizátor felületén. Ettől függetlenül a Pd/PDA/MNP több körben újrahasznosíthatónak bizonyult transzfer hidrogénezési és Suzuki reakcióban is. Utóbbiban azonban nagyobb mértékű Pd leoldódást figyeltünk meg a katalizátorról, amit ICP-MS mérések is igazoltak. A Pd leoldódás okozta katalitikus aktivitáscsökkenést jobban befolyásolta a reakcióidő, mint az emelt hőmérséklet, ugyanis $80^{\circ} \mathrm{C}$-on 5 perces reakciókban később következett be a teljes dezaktiválódás, mint szobahőmérsékleten 2 órás reakciók során. A Suzuki reakcióban megfigyeltekhez hasonló újrahasznosíthatóságot tapasztaltunk tandem Suzuki reakció/transzfer hidrogénezésben. Ezzel szemben Heck reakció során már a második körben inaktívvá vált a Pd/PDA/MNP.

Mind a négy reakció esetén sikeres méretnövelést hajtottunk végre, bizonyítva ezzel a rendszerek hasznosíthatóságát akár mindennapi laboratóriumi gyakorlatban is.

PDA filmet kvarc lapon létrehozva, majd erre arany nanorészecskéket rögzítve előállítottunk egy kompozit felületet (Q-PDA-Au), amelyen fotoizomerizálható molekularétegek izomerizációját, és ligandumcseréjét is végre tudtuk hajtani (II. ábra). 


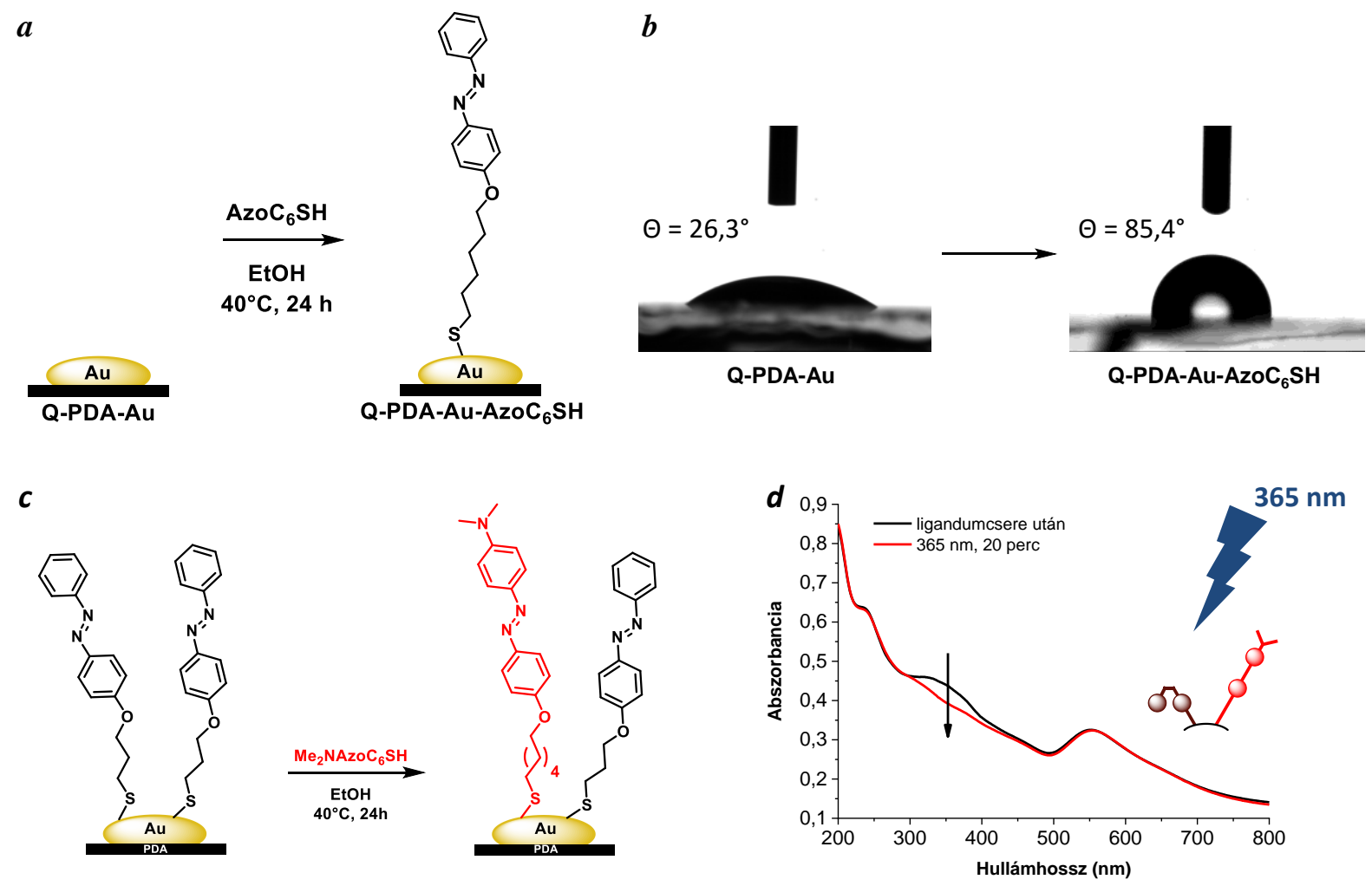

II. ábra ( $a$ ) Azobenzol származék Q-PDA-Au felületre történő rögzítésének sematikus ábrázolása, $(b)$ víz-kontaktszög változása a felületmódosítás hatására. (c) Kétkomponensű felület létrehozása ligandumcserével, és (d) az egyik komponens szelektív izomerizációjának követése UV-Vis spektrofotometriával.

A határfelületi ligandumcserére fókuszálva, előállítottunk különböző abszorpciós maximumokkal rendelkező azobenzol származékokat, ami segítette az egyes származékok felületen történő megkülönböztetését abszorpciós spektrumuk alapján. Előállítottunk alkilamin-, valamint alkil-tiol-terminális azobenzolokat, hogy kihasználhassuk a tiolcsoport nagyobb Au-affinitását amin $\rightarrow$ tiol ligandumcserében. Ezen kívül propil-, és hexil-lánccal rendelkező azo-alkiltiol származékok elöállításával vizsgálni terveztük az alkil-lánc hosszának hatását a ligandumcserére. UV-Vis spektrofotometriás és víz-kontaktszög mérések alapján megállapítottuk, hogy a Q-PDA-Au felületen rögzített azobenzol származékaink gyors, reverzibilis izomerizációra képesek. Ez igaznak bizonyult még a rövid, propil-láncú molekulára is, amelynek Au felületen való izomerizációja, a szakirodalom szerint, erősen gátolt. Kivételt a könnyü izomerizálhatóság alól egyedül a 4' helyzetben dimetil-amin szubsztituenst tartalmazó azobenzol származék jelentett, aminek tercier nitrogénje vagy az $\mathrm{Au}$ felülethez koordinálva, vagy a PDA funkciós csoportjaival hidrogén kötést létesítve már nem 
volt képes a cisz $\rightarrow$ transz visszaizomerizációra. Ligandumcsere folyamatokat vizsgálva megállapítottuk, hogy az amin-terminális molekulák gyorsan, nagy százalékban lecserélhetők a tiol-terminálisakra. Ezen kívül tiol $\rightarrow$ tiol csere is lehetséges, ami az alkil-lánc hosszának növekedésével egyre lassabban megy végbe, azonos körülmények között. Végül, ligandumcserével előállítottunk egy kétkomponensü Q-PDA-Au-,,Azo” határfelületet, amelyben mindkét ligandum megőrizte izomerizációs készségét.

Mindezen eredmények tükrében úgy véljük, hogy a PDA egy, a kémia több területén alkalmazható, multifunkciós polimer, amely a jövőben összetett rendszerek építőköve lehet. 


\section{Summary}

In our work, we exploited the autopolymerization of dopamine to creat polydopamine (PDA) supported catalysts and photoresponsive surfaces. For the construction of these systems, we harnessed the universal adhesivity and redox activity of PDA.

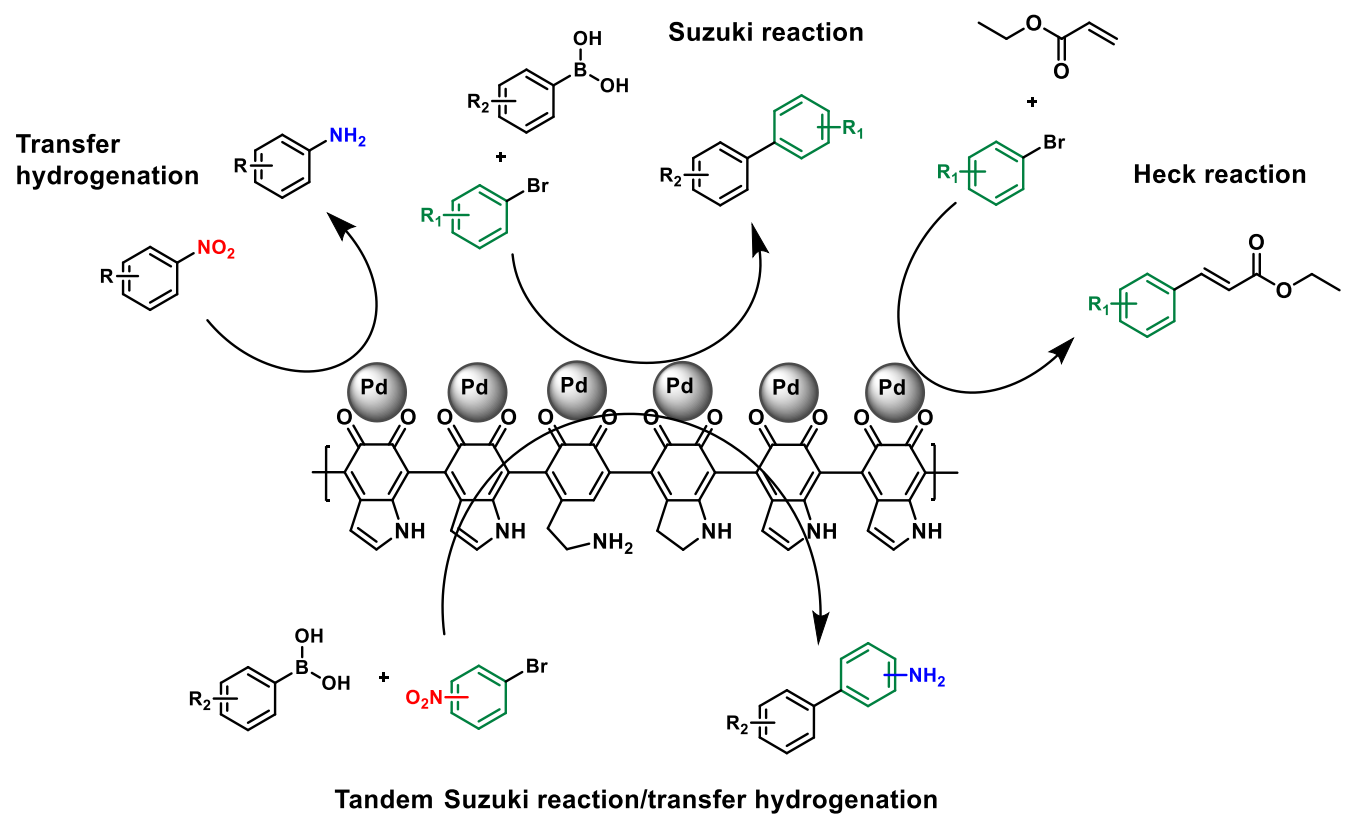

Figure I. Pd/PDA catalysed organic transformations.

For catalytic transformations, we prepared Pd nanoparticle doped PDA using the methanolic solution of $\mathrm{Pd}(\mathrm{OAc})_{2}$ as a $\mathrm{Pd}$ source. Because of the metal particle stabilizing ability of PDA, small Pd nanoparticles with a diameter of $1-3 \mathrm{~nm}$ were appeared on the PDA surface, and proved to be highly active in multiple Pd-catalyzed reactions (Figure I.). The reduction of a wide range of aromatic nitro compounds to the corresponding anilines could be efficiently performed in relatively short rection times $(60 \mathrm{~min})$, in the presence of a benchstable hydrogen source ( $\mathrm{HCOONa})$, and a renewable solvent (96 V/V\% EtOH). However, the carbonyl reduction was not as general as the nitro reduction, and only aromatic ketones could be reduced to the corresponding alcohols. In transfer hydrogenation reactions aldehyde functional groups were unaffected, probably because of their imine formation with the amine moieties of PDA, which we identified as a possible catalyst deactivation mechanism. Pd/PDA was also an active catalyst in the Heck reaction of aryl halides and ethyl acrylates. Importantly, we observed superior catalytic activities in the Suzuki reactions of aryl halides 
and arylboronic acids. In many cases, full conversions were achieved within 5 minutes at $80^{\circ} \mathrm{C}$, and in $2-3$ hours at room temperature. Moreover, the Suzuki coupling of 4-bromonitrobenzene and phenylboronic acid resulted in high yields in the presence of only $18 \mathrm{ppm}$ $\left(1.8 \times 10^{-3} \mathrm{~mol} \%\right) \mathrm{Pd}$. We presumed that this elevated catalytic activity is due to the relatively small Pd nanoparticle size. This particle size dependent catalytic activity was further explored by control experiments, where we found decreased activity parallel with increased Pd particle diameter.

In both Suzuki reactions and catalytic transfer hydrogenations, the solvent (96 V/V\% $\mathrm{EtOH})$ and the catalyst (Pd/PDA) were the same, therefore, to take advantage of the similarities in these systems, we combined the two reactions in a one-pot, tandem process. In this tandem Suzuki reaction/transfer hydrogenation process, aminobiphenyles were prepared from arylboronic acids and nitroaryl halides in mostly good to high yields. However, decreased selectivity and low yields were observed in many cases when the reaction rate of the Suzuki coupling was comparable to that of the transfer hydrogenation. We were able to increase these yields by applying different temperatures during the two reaction steps. Onepot Suzuki coupling and nitro reduction of heteroaryl halides with 3-nitrophenylboronic acid were conducted, however, in these cases the delayed addition of the reducing agent (HCOONa) was necessary to suppress side reactions.

We have also prepared a PDA supported Pd catalyst on a magnetite core (Pd/PDA/MNP) to simplify catalyst recycling. However, larger, $5-8 \mathrm{~nm} \mathrm{Pd}$ nanoparticles were generated on the PDA/MNP surface compared to neat PDA (1 - $3 \mathrm{~nm} \mathrm{Pd}$ size $)$. Pd/PDA/MNP catalyst was found recyclable in transfer hydrogenation and Suzuki reactions. However, in the latter case, an elevated Pd leaching was observed, which resulted in decreased activity after the $4^{\text {th }}$ run. We found that longer reaction time resulted in greater decrease of catalytic activity, than higher reaction temperature. Similar recyclability was observed in tandem Suzuki reaction/transfer hydrogenation. On the other hand, Pd/PDA/MNP became inactive already in the second run in Heck reaction, probably because of the high Pd leaching, and nanoparticle aggregation.

Successful large-scale experiments indicated the applicability of all four reaction systems in everyday preparative tasks. 


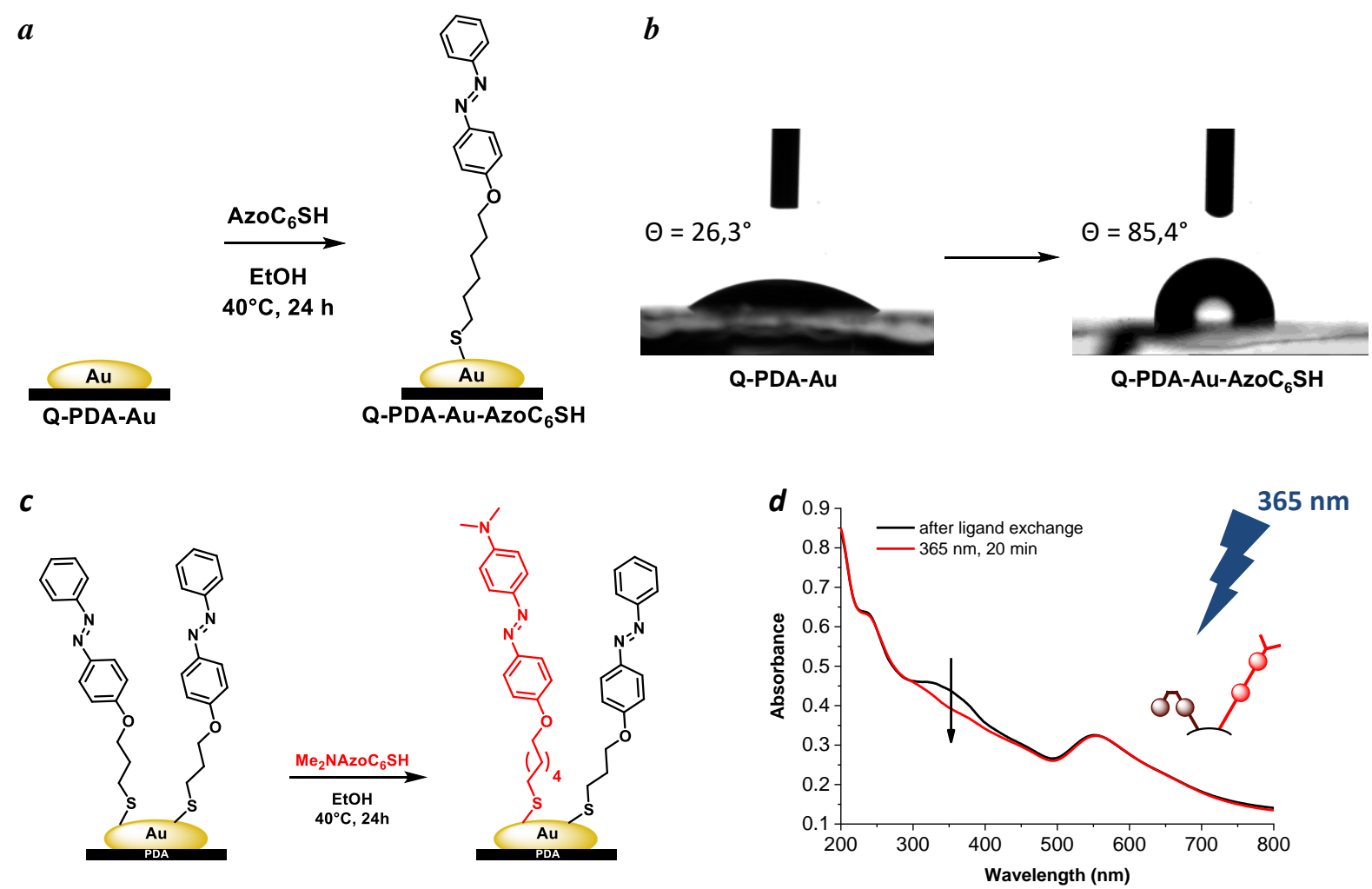

Figure II. (a) Schematic representation of the Q-PDA-Au surface modification with an azobenzene derivative, and (b) change in water contact angle during the process. (c) Preparation of a multicomponent surface via ligand exchange reaction, and $(d)$ selective photoswitching of one component in the mixed layer monitored by UV-Vis spectrophotometry.

By coating quartz slides with PDA and anchoring Au nanoparticles on its surface, we created a composite material (Q-PDA-Au) which was capable to host photoisomerizable molecules and enabled ligand exchange processes (Figure II.).

To examine ligand exchange processes on Q-PDA-Au surface, we synthesized azobenzene derivatives that exhibit different UV-Vis absorption maxima for easier identification by UV-Vis spectroscopy. We prepared amine and thiol terminated derivatives to harness the higher affinity of thiol to $\mathrm{Au}$ in an amine $\rightarrow$ thiol exchange. Moreover, the impact of alkyl chainlength was also investigated by preparing a propyl-, and a hexyl-chained azobenzene derivative. We demonstrated via UV-Vis spectrophotometry and water contact angle measurements that the azobenzenes kept their fast and reversible switching property, thermal-, and photostability on Q-PDA-Au surface. Only exception was the 4'-dimethylamino substituted azobenzene, which was unable to isomerize back from its cis configuration to trans form after trans $\rightarrow$ cis photoswitching. This phenomenon can be explained either by the coordination of its tertiary nitrogen to the Au surface, or by the formation of hydrogen bond with the $\mathrm{OH}$ and $\mathrm{NH}_{2}$ moieties of PDA. In ligand exchange processes we observed significant 
amine to thiol exchange capability, moreover, thiol to thiol exchange was also occurred on QPDA-Au surface, however with decreasing efficiency along with increasing alkyl-chainlength. Furthermore, a mixed Q-PDA-Au-,,Azo” surface was created, where both ligands were retained their photoisomerizability, however the cis $\rightarrow$ trans reverse isomerization of $\mathrm{Me}_{2} \mathrm{NAzoC}_{6} \mathrm{SH}$ on the mixed surface was not observable in this case either.

We conclude that PDA is an environmentally being, multifunctional polymer which can be a building block of complex systems in the near future. 


\section{Irodalomjegyzék}

1. G. Petroffe, C. Wang, X. Sallenave, G. Sini, F. Goubard, S. Péralta, J. Mater. Chem. A 2015, 3, 11533-11542.

2. J. H. Waite, M. L. Tanzer, Science 1981, 212, 1038-1040.

3. H. Lee, N. F. Scherer, P. B. Messersmith, Proc. Natl. Acad. Sci. USA 2006, 103, 12999 13003.

4. H. Lee, S. M. Dellatore, W. M. Miller, P. B. Messersmith, Science 2007, 318, 426-430.

5. Q. Ye, F. Zhou, W. Liu, Chem. Soc. Rev. 2011, 40, 4244-4258.

6. Y. Liu, K. Ai, L. Lu, Chem. Rev. 2014, 114, 5057-5115.

7. J. H. Ryu, P. B. Messersmith, H. Lee, ACS Appl. Mater. Interfaces 2018, 10, $7523-7540$.

8. J. Liebscher, Eur. J. Org. Chem. 2019, 4976-4994.

9. N. F. Della Vecchia, A. Luchini, A. Napolitano, G. D’Errico, G. Vitiello, N. Szekely, M. d'Ischia, L. Paduano, Langmuir 2014, 30, 9811-9818.

10. I. You, H. Jeon, K. Lee, M. Do, Y. C. Seo, H. A. Lee, H. Lee, J. Ind. Eng. Chem. 2017, $46,379-385$.

11. F. Ponzio, J. Barthès, J. Bour, M. Michel, P. Bertani, J. Hemmerlé, M. d'Ischia, V. Ball, Chem. Mater. 2016, 28, 4697-4705.

12. M. Salomäki, L. Marttila, H. Kivelä, T. Ouvinen, J. Lukkari, J. Phys. Chem. B 2018, $122,6314-6327$.

13. L. Jiao, Z. Xu, W. Du, H. Li, M. Yin, ACS Appl. Mater. Interfaces 2017, 9, 28339-28345.

14. X. Du, L. Li, J. Li, C. Yang, N. Frenkel, A. Welle, S. Heissler, A. Nefedov, M. Grunze, P. A. Levkin, Adv. Mater. 2014, 26, 8029-8033.

15. E. Herlinger, R. F. Jameson, W. Linert, J. Chem. Soc. Perk. Trans. 2 1995, 259-263.

16. M. L. Alfieri, L. Panzella, S. L. Oscurato, M. Salvatore, R. Avolio, M. E. Errico, P. Maddalena, A. Napolitano, M. d'Ischia, Biomimetics 2018, 3, 26.

17. J. Liebscher, R. Mrówczyński, H. A. Scheidt, C. Filip, N. D. Hădade, R. Turcu, A. Bende, S. Beck, Langmuir 2013, 29, 10539-10548.

18. P. Delparastan, K. G. Malollari, H. Lee, P. B. Messersmith, Angew. Chem. Int. Ed. 2019, 58, 1077-1082.

19. R. Mrówczynski, A. Bunge, J. Liebscher, Chem. Eur. J. 2014, 20, 8647-8653. 
20. A. Kunfi, G. London, Synthesis 2019, 51, 2829-2838.

21. A. Molnar, ChemCatChem, elöször publikált verzió: 2019. december 20., DOI: $10.1002 /$ cctc. 201902125

22. X. Liu, J. Cao, H. Li, J. Li, Q. Jin, K. Ren, J. Ji, ACS Nano 2013, 7, 9384-9395.

23. T. Aditya, A. Pal, T. Pal, Chem. Commun. 2015, 51, 9410-9431.

24. T. Zeng, X. Zhang, H. Niu, Y. Ma, W. Li, Y. Cai, App. Catal. B 2013, 134-135, 26-33.

25. R. Liu, Y. Guo, G. Odusote, F. Qu, R. D. Priestley, ACS Appl. Mater. Interfaces 2013, 5, 9167-9171.

26. J. Luo, N. Zhang, R. Liu, X. Liu, RSC Adv. 2014, 4, 64816-64824.

27. I. Kim, H. Y. Son, M. Y. Yang, Y. S. Nam, ACS Appl. Mater. Interfaces 2015, 7, $14415-14422$.

28. J. Cao, S. Mei, H. Jia, A. Ott, M. Ballauff, Y. Lu, Langmuir 2015, 31, 9483-9491.

29. Y. Ni, G. Tong, J. Wang, H. Li, F. Chen, C. Yu, Y. Zhou, RSC Adv. 2016, 6, 4069840705.

30. Q. Wei, R. Shi, D. Lu, Z. Lei, RSC Adv. 2016, 6, 29245-29253.

31. Z. Wu, H. Lin, Y. Wang, X. Yu, J. Li, Z. Xiong, Y. Wang, Y. Huang, T. Chen, F. Liu, RSC Adv. 2016, 6, 62302-62309.

32. J. Yu, S. Lu, W. Xu, G. He, D. He, Appl. Organomet. Chem. 2017, 31, 3785.

33. J. Zhang, Q. Fang, J. Duan, H. Xu, H. Xu, S. Xuan, Langmuir, 2018, 34, 4298-4306.

34. Z. Zeng, M. Wen, B. Yu, G. Ye, X. Huo, Y. Lu, J. Chen, ACS Appl. Mater. Interfaces, 2018, 10, 14735-14743.

35. G. H. Choi, D. K. Rhee, A. R. Park, M. J. Oh, S. Hong, J. J. Richardson, J. Guo, F. Caruso, P. J. Yoo, ACS Appl. Mater. Interfaces 2016, 8, 3250-3257.

36. S. Lu, J. Yu, Y. Cheng, Q. Wang, A. Barras, W. Xu, S. Szunerits, D. Cornu, R. Boukherroub, Appl. Surf. Sci. 2017, 411, 163-169.

37. E. Cao, W. Duan, F. Wang, A. Wang, Y. Zheng, Carbohydr. Polym. 2017, 158, 44-50.

38. L. Du, A. Guo, A. Cai, Micro Nano Lett. 2018, 13, 518-523.

39. Y. Zeng, W. Liu, Z. Wang, S. Singamaneni, R. Wang, Langmuir 2018, 34, 4036-4042.

40. Y. Song, H. Jiang, B. Wang, Y. Kong, J. Chen, ACS Appl. Mater. Interfaces 2018, 10, 1792-1801.

41. T. K. Das, S. Ganguly, P. Bhawal, S. Remanan, S. Mondal, N. C. Das, Appl. Nanosci. 2018, 8, 173-186.

42. J.-X. Ma, H. Yang, S. Li, R. Ren, J. Li, X. Zhang, J. Ma, RSC Adv. 2015, 5, 9752097527. 
43. J. Xi, J. Xiao, F. Xiao, Y. Jin, Y. Dong, F. Jing, S. Wang, Sci. Rep. 2016, 6, 21904.

44. Y. Liu, G. Li, R. Qin, D. Chen, Langmuir 2016, 32, 13675-13686.

45. P. Fu, Z. Xiao, Y. Liu, L. Wang, X. Zhang, G. Li, ChemistrySelect 2018, 3, 3351-3361.

46. S.-W. Bian, S. Liu, L. Chang, J. Mater. Sci. 2016, 51, 3643-3649.

47. X. Yu, G. Cheng, S.-Y. Zheng, Sci. Rep. 2016, 6, 25459.

48. Y. Rong, A. Dandapat, Y. Huang, Y. Sasson, L. Zhang, L. Dai, J. Zhang, Z. Guoc, T. Chen, $R S C$ Adv. 2016, 6, 10713-10718.

49. W. Ye, J. Yu, Y. Zhou, D. Gao, D. Wang, C. Wang, D. Xue, Appl. Catal. B 2016, 181, 371-378.

50. M. Zhang, G. Li, X. Sun, Y. Jiang, X. Zhang, J. Mater. Chem. A 2017, 5, 20789-20796.

51. S. K. Movahed, N. F. Lehi, M. Dabiri, J. Catal. 2018, 364, 69-79.

52. T. Mizoroki, K. Mori, A. Ozaki, Bull. Chem. Soc. Jpn. 1971, 44, 581.

53. R. F. Heck, Acc. Chem. Res. 1979, 12, 146-151.

54. N. Miyaura, K. Yamada, A. Suzuki, Tetrahedron Lett. 1979, 20, 3437-3440.

55. I. P. Beletskaya, A. V. Cheprakov, Chem. Rev. 2000, 100, 3009-3066.

56. L. Yin, J. Liebscher, Chem. Rev. 2007, 107, 133-173.

57. N. T. S. Phan, M. Van Der Sluys, C. W. Jones, Adv. Synth. Catal. 2006, 348, 609-679.

58. D. Wang, D. Astruc, Coord. Chem. Rev. 2013, 257, 2317-2334.

59. W. Xu, C. Liu, D. Xiang, Q. Luo, Y. Shu, H. Lin, Y. Hu, Z. Zhang, Y. Ouyang, RSC Adv. 2019, 9, 34595-34600.

60. P. P. Das, V. C. Prabhakaran, S. Nanda, D. Sen, B. Chowdhury, ChemistrySelect 2019, $4,3823-3832$.

61. Y. Li, E. Boone, M. A. El-Sayed, Langmuir 2002, 18, 4921-4925.

62. S. Chatterjee, S. K. Bhattacharya, ACS Omega 2018, 3, 12905-12913.

63. A. V. Dubey, A. V. Kumar, RSC Adv. 2016, 6, 46864-46870.

64. R. Ma, P. Yang, Y. Ma, F. Bian, ChemCatChem 2018, 10, 1446-1454.

65. E. Farzad, H. Veisi, J. Ind. Eng. Chem. 2018, 60, 114-124.

66. A. Xie, K. Zhang, F. Wu, N. Wang, Y. Wang, M. Wang, Catal. Sci. Technol. 2016, 6, 1764-1771.

67. X. Fei, W. Kong, X. Chen, X. Jiang, Z. Shao, J. Y. Lee, ACS Catal. 2017, 7, 24122418 .

68. Y. Li, L. Xu, B. Xu, Z. Mao, H. Xu, Y. Zhong, L. Zhang, B. Wang, X. Sui, ACS Appl. Mater. Interfaces 2017, 9, 17155-17162.

69. F.-X. Felpin, E. Fouquet, ChemSusChem 2008, 1, 718-724. 
70. M. J. Climent, A. Corma, S. Iborra, M. J. Sabater, ACS Catal. 2014, 4, 870-891.

71. A. Behr, A. J. Vorholt, K. A. Ostrowski, T. Seidensticker, Green Chem. 2014, 16, 9821006.

72. D. Robert, B. Adrian, W.-H. Cheung, F. Firooznia, M. M. Hamilton, L. A. McDermott, Y. Qian, J. Tan, W. Yun, US Patent 2009 US8058299B2.

73. L. F. Tietze, U. Beifuss, Angew. Chem. Int. Ed. 1993, 32, 131-163.

74. K. C. Nicolaou, D, J. Edmonds, P. G. Bulger, Angew. Chem. Int. Ed. 2006, 45, 71347186.

75. L. Pedersen, M. F. Mady, M. O. Sydnes, Tetrahedron Lett. 2013, 54, 4772-4775.

76. F. Chahdoura, C. Pradel, M. Gómez, Adv. Synth. Catal. 2013, 355, 3648-3660.

77. A. Kumar, K. Purkait, S. K. Dey, A. Sarkar, A. Mukherjee, RSC Adv. 2014, 4, 3523335237.

78. P. M. Uberman, C. S. García, J. R. Rodríguez, S. E. Martín, Green Chem. 2017, 19, 739-748.

79. H.-S. Wang, Y.-C. Wang, Y.-M. Pan, S.-L. Zhao, Z.-F. Chen, Tetrahedron Lett. 2008, 49, 2634-2637.

80. S. Rohilla, P. Pant, N. Jain, RSC Adv. 2015, 5, 31311-31317.

81. B. S. Kumar, A. J. Amalia, K. Pitchumani, J. Mol. Catal. A: Chem. 2016, 423, 511-519.

82. A. Qazi, A. Sullivan, Dalton Trans. 2011, 40, 10637-10642.

83. B. L. Feringa, Angew. Chem. Int. Ed. 2017, 56, 11060-11078.

84. M. Kathan, S. Hecht, Chem. Soc. Rev. 2017, 46, 5536-5550.

85. M. Baroncini, L. Casimiro, C. Vet, J. Groppi, S. Silvi, A. Credi, ChemistryOpen 2018, 7, 169-179.

86. H. Nie, J. L. Self, A. S. Kuenstler, R. C. Hayward, J. R. de Alaniz, Adv. Optical Mater. 2019, 7, 1900224.

87. B. M. Neilson, C. W. Bielawski, ACS Catal. 2013, 3, 1874-1885.

88. R. Göstl, A. Senf, S. Hecht, Chem. Soc. Rev. 2014, 43, 1982-1996.

89. R. Dorel, B. L. Feringa, Chem. Commun. 2019, 55, 6477-6486.

90. J. Broichhagen, J. A. Frank, D. Trauner, Acc. Chem. Res. 2015, 48, 1947-1960.

91. M. M. Lerch, M. J. Hansen, G. M. van Dam, W. Szymanski, B. L. Feringa, Angew. Chem. Int. Ed. 2016, 55, 10978-10999.

92. Q. Zhang, D.-H. Qu, H. Tian, Adv. Optical Mater. 2019, 7, 1900033.

93. M. Baroncini, J. Groppi, S. Corra, S. Silvi, A. Credi, Adv. Optical Mater. 2019, 7, 1900392. 
94. H. M. D. Bandara, S. C. Burdette, Chem. Soc. Rev. 2012, 41, 1809-1825.

95. E. Merino, Chem. Soc. Rev. 2011, 40, 3835-3853.

96. M. Dong, A. Babalhavaeji, S. Samanta, A. A. Beharry, G. A. Woolley, Acc. Chem. Res. 2015, 48, 2662-2670.

97. H. Sell, C. Näther, R. Herges, Beilstein J. Org. Chem. 2013, 9, 1-7.

98. W. R. Browne, B. L. Feringa, Nat. Nanotechnol. 2006, 1, 25-35.

99. D. Kessler, F. D. Jochum, J. Choi, K. Char, P. Theato, ACS Appl. Mater. Interfaces 2011, 3, 124-128.

100. C. Kallweit, M. Bremer, D. Smazna, T. Karrock, R. Adelung, M. Gerken, Vacuum 2017, 146, 386-395.

101. J. Zhang, W. Zhang, N. Zhou, Y. Weng, Z. Hu, RSC Adv. 2014, 4, 24973-24977.

102. X. Liu, M. Cai, Y. Liang, F. Zhou, W. Liu, Soft Matter 2011, 7, 3331.

103. R. D. Mukhopadhyay, B. Vedhanarayanan, A. Ajayaghosh, Angew. Chem. Int. Ed. 2017, 129, 16234-16238.

104. S. Jia, W.-K. Fong, B. Graham, B. J. Boyd, Chem. Mater. 2018, 30, 2873-2887.

105. Y. Chen, Z. Li, H. Wang, Y. Pei, Y. Shi, J. Wang, Langmuir 2018, 34, 2784-2790.

106. S. O. Poelma, S. S. Oh, S. Helmy, A. S. Knight, G. L. Burnett, H. T. Soh, C. J. Hawker, J. Read de Alaniz, Chem. Commun. 2016, 52, 10525-10528.

107. G. B. Demirel, ChemPhysChem 2014, 15, 1693-1699.

108. C. Liu, Y. Jiang, C. Zhou, J. Caro, A. Huang, J. Mater. Chem. A 2018, 6, 24949-24955.

109. S. N. Ramanan, N. Shahkaramipour, T. Tran, L. Zhu, S. R. Venna, C.-K. Lim, A. Singh, P. N. Prasad, H. Lin, J. Membr. Sci. 2018, 554, 164-174.

110. O. Rifaie-Graham, S. Ulrich, N. F. B. Galensowske, S. Balog, M. Chami, D. Rentsch, J. R. Hemmer, J. Read de Alaniz, L. F. Boesel, N. Bruns, J. Am. Chem. Soc. 2018, 140, 8027-8036.

111. A. Balamurugan, H. Lee, Macromolecules 2016, 49, 2568-2574.

112. G. T. Carroll, M. M. Pollard, R. van Deldena, B. L. Feringa, Chem. Sci. 2010, 1, 97101.

113. S. Ulrich, J. R. Hemmer, Z. A. Page, N. D. Dolinski, O. Rifaie-Graham, N. Bruns, C. J. Hawker, L. F. Boesel, J. Read de Alaniz, ACS Macro Lett. 2017, 6, 738-742.

114. F.-Y. Tang, J.-N. Hou, K.-X. Liang, Y. Liu, L. Deng, Y.-N. Liu, New J. Chem. 2017, $41,6071-6075$. 
115. S. Singh, K. Friedel, M. Himmerlich, Y. Lei, G. Schlingloff, A. Schober, ACS Macro Lett. 2015, 4, 1273-1277.

116. A. Ulman, Chem. Rev. 1996, 96, 1533-1554.

117. J. C. Love, L. A. Estroff, J. K. Kriebel, R. G. Nuzzo, G. M. Whitesides, Chem. Rev. 2005, 105, 1103-1169.

118. M. Nakagawa, R. Watase, K. Ichimura., Chem. Lett. 1999, 1209-1210.

119. S. D. Evans, S. R. Johnson, H. Ringsdorf, L. M. Williams, H. Wolf, Langmuir 1998, 14, 6436-6440.

120. U. Jung, O. Filinova, S. Kuhn, D. Zargarani, C. Bornholdt, R. Herges, O. Magnussen, Langmuir 2010, 26, 13913-13923.

121. N. Heinemann, J. Grunau, T. Leißner, O. Andreyev, S. Kuhn, U. Jung, D. Zargarani, R. Herges, O. Magnussen, M. Bauer, Chem. Phys. 2012, 402, 22-28.

122. D. T. Valley, M. Onstott, S. Malyk, A. V. Benderskii, Langmuir, 2013, 29, $11623-11631$.

123. M. Han, T. Honda, D. Ishikawa, E. Ito, M. Harab, Y. Norikane, J. Mater. Chem. 2011, $21,4696-4702$.

124. D. Ishikawa, E. Ito, M. Han, M. Hara, Langmuir 2013, 29, 4622-4631.

125. M. Kaneta, T. Honda, K. Onda, M. Han, New J. Chem. 2017, 41, 1827-1833.

126. T. Moldt, D. Brete, D. Przyrembel, S. Das, J. R. Goldman, P. K. Kundu, C. Gahl, R. Klajn, M. Weinelt, Langmuir 2015, 31, 1048-1057.

127. M. J. Hostetler, A. C. Templeton, R. W. Murray, Langmuir 1999, 15, 3782-3789.

128. A. Caragheorgheopol, V. Chechik, Phys. Chem. Chem. Phys. 2008, 10, 5029-5041.

129. A. Dong, X. Ye, J. Chen, Y. Kang, T. Gordon, J. M. Kikkawa, C. B. Murray, J. Am. Chem. Soc. 2011, 133, 998-1006.

130. T. Kang, D. X. Oh, J. Heo, H.-K. Lee, S. Choy, C. J. Hawker and D. S. Hwang, ACS Appl. Mater. Interfaces 2015, 7, 24656-24662.

131. L. Yu, J. Sun, Q. Wang, Y. Guan, L. Zhou, J. Zhang, L. Zhang, H. Yang, Small, 2017, 13,1700480 .

132. M. Kluenker, M. Mondeshki, M. N. Tahir, W. Tremel, Langmuir 2018, 34, 1700-1710.

133. G. G. Baralia, A.-S. Duwez, B. Nysten, A. M. Jonas, Langmuir 2005, 21, 6825-6829.

134. E. Beurer, N. V. Venkataraman, A. Rossi, F. Bachmann, R. Engeli, N. D. Spencer, Langmuir 2010, 26, 8392-8399. 
135. G. Picardi, A. Królikowska, R. Yasukuni, M. Chaigneau, M. Escude, V. Mourier, C. Licitra, R. Ossikovski, ChemPhysChem 2014, 15, 276-282.

136. D. Manna, T. Udayabhaskararao, H. Zhao, R. Klajn, Angew. Chem. Int. Ed. 2015, 54, 12394-12397.

137. Z. Chu, Y. Han, T. Bian, S. De, P. Král, R. Klajn, J. Am. Chem. Soc. 2019, 141, 19491960.

138. A. Kunfi, V. Szabó, Á. Mastalir, I. Bucsi, M. Mohai, P. Németh, I. Bertóti, G. London, ChemCatChem 2017, 9, 3236-3244.

139. A. Kunfi, Z. May, P. Németh, G. London, J. Catal. 2018, 361, 84-93.

140. P. Oswal, A. Arora, J. Kaushal, G. K. Rao, S. Kumar, A. K. Singh, Arun Kumar, RSC Adv. 2019, 9, 22313-22319.

141. M. Blanco, D. Mosconi, C. Tubaro, A. Biffis, D. Badocco, P. Pastore, M. Otyepka, A. Bakandritsos, Z. Liu, W. Ren, S. Agnoli, G. Granozzi, Green Chem 2019, 21, 52385247.

142. N. Dehury, N. Maity, S. K. Tripathy, J.-M. Basset, S. Patra, ACS Catal. 2016, 6, 55355540 .

143. Y. Ding, L.-T. Weng, M. Yang, Z. Yang, X. Lu, N. Huang, Y. Leng, Langmuir 2014, $30,12258-12269$.

144. M. Zhang, X. He, L. Chen, Y. Zhang, J. Mater. Chem. 2010, 20, 10696-10704.

145. S. F. J. Hackett, R. M. Brydson, M. H. Gass, I. Harvey, A. D. Newman, K. Wilson, A. F. Lee, Angew. Chem. Int. Ed. 2007, 46, 8593-8596.

146. A. F. Lee, K. Wilson, Green Chem 2004, 6, 37-42.

147. A. Kunfi, Á. Mastalir, I. Bucsi, G. London, React. Kinet. Mech. Catal. 2016, 119, 165178.

148. V. F. Slagt, A. H. M. de Vries, J. G. de Vries, R. M. Kellogg, Org. Process Res. Dev. 2010, $14,30-47$.

149. R. M. Crooks, M. Zhao, L. Sun, V. Chechik, L. K. Yeung, Acc. Chem. Res. 2001, 34, $181-190$.

150. S. Chatterjee, S. K. Bhattacharya, ACS Omega 2018, 3, 12905-12913.

151. A. Kunfi, R. B. Vlocskó, Zs. Keresztes, M. Mohai, I. Bertóti, Á. Ábrahám, É. Kiss, G. London, ChemPlusChem 2020, 85, 797-805.

152. F. Bernsmann, V. Ball, F. Addiego, A. Ponche, M. Michel, J. J. de Almeida Gracio, V. Toniazzo, D. Ruch, Langmuir 2011, 27, 2819-2825. 
153. V. Ball, J. Gracio, M. Vila, M. K. Singh, M.-H. Metz-Boutigue, M. Michel, J. Bour, V. Toniazzo, D. Ruch, M. J. Buehler, Langmuir 2013, 29, 12754-12761.

154. Y. Wei, S. Han, J. Kim, S. Soh, B. A. Grzybowski, J. Am. Chem. Soc. 2010, 132, $11018-11020$.

155. C.-Y. Liu, C.-J. Huang, Langmuir 2016, 32, 5019-5028.

156. Y. Du, H.-C. Yang, X.-L. Xu, J. Wu, Z-K. Xu, ChemCatChem 2015, 7, 3822-3825.

157. C. Gahl, R. Schmidt, D. Brete, S. Paarmann, M. Weinelt, Surf. Sci. 2016, 643, 183-189.

158. R. Dong, B. Zhu, Y. Zhou, D. Yan, X. Zhu, Polym. Chem. 2013, 4, 912-915.

159. J. Wang, Q. Li, S. Yi, X. Chen, Soft Matter 2017, 13, 6490-6498.

160. E. Wolfram, R. Faust, in J.F. Padday (Ed.), Wetting, Spreading and Adhesion, Academic Press, London, 1978, p. 213.

161. É. Kiss, Coll. Surf. A, 1993, 76, 135-140.

162. A. B. D. Cassie, Discuss. Faraday Soc. 1948, 3, 11-16.

163. J. W. Drelich, Adv. Coll. Interface Sci. 2019, 267, 1-14.

164. C. Della Volpe, D. Maniglio, S. Siboni, M. Morra, Oil \& Gas Sci. Technol. 2001, 56, 922.

165. L. Gao, T. J. McCarthy, Langmuir 2009, 25, 14105-14115. 


\section{Mellékletek}

\subsection{Katalitikus átalakítások során nyert termékek NMR jellemzése}

${ }^{1} \mathrm{H} \mathrm{NMR}\left(500 \mathrm{MHz}, \mathrm{CDCl}_{3}\right) \delta=7.85(\mathrm{~d}, J=8.7 \mathrm{~Hz}, 2 \mathrm{H}), 6.63(\mathrm{~d}, J=8.7 \mathrm{~Hz}$, $2 \mathrm{H}), 4.31(\mathrm{q}, J=7.1 \mathrm{~Hz}, 2 \mathrm{H}), 4.04(\mathrm{~s}, 2 \mathrm{H}), 1.36(\mathrm{t}, J=7.1 \mathrm{~Hz}, 3 \mathrm{H}) \mathrm{ppm} .{ }^{13} \mathrm{C}$ NMR $(126 \mathrm{MHz}$, $\left.\mathrm{CDCl}_{3}\right) \delta=166.64,150.67,131.51,120.16,113.75,60.25,14.39 \mathrm{ppm}$.<smiles>Nc1ccccc1</smiles>

${ }^{1} \mathrm{H} \mathrm{NMR}\left(500 \mathrm{MHz}, \mathrm{CDCl}_{3}\right) \delta=7.20(\mathrm{t}, J=7.9 \mathrm{~Hz}, 2 \mathrm{H}), 6.80(\mathrm{t}, J=7.4 \mathrm{~Hz}, 1 \mathrm{H})$, $6.71(\mathrm{~d}, J=7.5 \mathrm{~Hz}, 2 \mathrm{H}), 3.63(\mathrm{~s}, 2 \mathrm{H}) \mathrm{ppm} .{ }^{13} \mathrm{C} \mathrm{NMR}\left(126 \mathrm{MHz}, \mathrm{CDCl}_{3}\right) \delta=146.42,129.30$, $118.55,115.13 \mathrm{ppm}$.

$(\mathrm{s}, 2 \mathrm{H}), 2.14(\mathrm{H})$
$119.29,115.57$

${ }^{1} \mathrm{H}$ NMR (500 MHz, DMSO) $\delta=8.27(\mathrm{~s}, 1 \mathrm{H}), 6.42(\mathrm{dd}, J=29.6,8.6 \mathrm{~Hz}, 4 \mathrm{H})$, 4.32 (s, 2H) ppm. ${ }^{13} \mathrm{C}$ NMR (126 MHz, DMSO) $\delta=148.66,141.08,115.97,115.67$ ppm.<smiles>Nc1cccc(O)c1</smiles>

${ }^{1} \mathrm{H}$ NMR (400 MHz, DMSO) $\delta=8.84(\mathrm{~s}, 1 \mathrm{H}), 6.81(\mathrm{t}, J=8.2 \mathrm{~Hz}, 1 \mathrm{H}), 6.10-$ $5.90(\mathrm{~m}, 3 \mathrm{H}), 4.87$ (s, 2H) ppm. ${ }^{13} \mathrm{C}$ NMR (101 MHz, DMSO) $\delta=158.92,150.65,130.28$, 106.33, 104.23, 101.89 ppm.<smiles>Nc1ccc(N)cc1</smiles>

${ }^{1} \mathrm{H}$ NMR $\left(500 \mathrm{MHz}, \mathrm{CDCl}_{3}\right) \delta=6.57(\mathrm{~s}, 4 \mathrm{H}), 3.32(\mathrm{~s}, 4 \mathrm{H}) \mathrm{ppm} .{ }^{13} \mathrm{C}$ NMR $(126$ $\left.\mathrm{MHz}, \mathrm{CDCl}_{3}\right) \delta=138.57,116.70 \mathrm{ppm}$.<smiles>COc1ccc(N)c(C)c1</smiles>

${ }^{1} \mathrm{H}$ NMR $\left(500 \mathrm{MHz}, \mathrm{CDCl}_{3}\right) \delta=6.67(\mathrm{~s}, 1 \mathrm{H}), 6.66-6.59(\mathrm{~m}, 2 \mathrm{H}), 3.74(\mathrm{~s}$, 3H), 3.29 (s, 2H), 2.17 (s, 3H) ppm. $\left.{ }^{13} \mathrm{C} \mathrm{NMR} \mathrm{(126} \mathrm{MHz,} \mathrm{CDCl}_{3}\right) \delta=152.74,138.18,124.00$, $116.41,116.02,112.13,55.72,17.66 \mathrm{ppm}$. 
${ }^{1} \mathrm{H}$ NMR (500 MHz, DMSO) $\delta=8.92(\mathrm{~s}, 1 \mathrm{H}), 6.85(\mathrm{~d}, J=8.3 \mathrm{~Hz}, 1 \mathrm{H}), 6.39$ $(\mathrm{d}, J=1.7 \mathrm{~Hz}, 1 \mathrm{H}), 6.33(\mathrm{dd}, J=8.3,2.1 \mathrm{~Hz}, 1 \mathrm{H}), 4.85(\mathrm{~s}, 2 \mathrm{H}), 2.01(\mathrm{~s}, 3 \mathrm{H}), 1.95(\mathrm{~s}, 3 \mathrm{H})$ ppm. ${ }^{13} \mathrm{C}$ NMR (126 MHz, DMSO) $\delta=168.46,146.77,133.76,127.30,125.75,115.67$, $111.85,23.37,18.39 \mathrm{ppm}$.

$\mathrm{NH}_{2}$

${ }^{1} \mathrm{H}$ NMR $\left(500 \mathrm{MHz}, \mathrm{CDCl}_{3}\right) \delta=7.32(\mathrm{~d}, J=7.6 \mathrm{~Hz}, 1 \mathrm{H}), 7.27-7.18(\mathrm{~m}, 2 \mathrm{H})$, $6.86(\mathrm{dd}, J=7.9,1.5 \mathrm{~Hz}, 1 \mathrm{H}), 3.73(\mathrm{~s}, 2 \mathrm{H}), 2.54(\mathrm{~s}, 3 \mathrm{H}) \mathrm{ppm} .{ }^{13} \mathrm{C}$ NMR $\left(126 \mathrm{MHz}, \mathrm{CDCl}_{3}\right) \delta$ $=198.33,146.57,138.26,129.40,119.65,118.91,114.05,26.64$ ppm.<smiles>CC(O)c1ccccc1</smiles>

${ }^{1} \mathrm{H} \operatorname{NMR}\left(500 \mathrm{MHz}, \mathrm{CDCl}_{3}\right) \delta=7.41-7.31(\mathrm{~m}, 4 \mathrm{H}), 7.30-7.22(\mathrm{~m}, 1 \mathrm{H}), 4.88(\mathrm{q}, J$ $=6.5 \mathrm{~Hz}, 1 \mathrm{H}), 2.09(\mathrm{~s}, 1 \mathrm{H}), 1.49(\mathrm{~d}, J=6.5 \mathrm{~Hz}, 3 \mathrm{H}) \mathrm{ppm} .{ }^{13} \mathrm{C} \mathrm{NMR}\left(126 \mathrm{MHz}, \mathrm{CDCl}_{3}\right) \delta=$ $145.82,128.45,127.41,125.37,70.34,25.11 \mathrm{ppm}$.

(1)

${ }^{1} \mathrm{H}$ NMR $\left(500 \mathrm{MHz}, \mathrm{CDCl}_{3}\right) \delta=7.29(\mathrm{~d}, J=8.7 \mathrm{~Hz}, 2 \mathrm{H}), 6.86(\mathrm{~d}, J=8.7 \mathrm{~Hz}$, $2 \mathrm{H}), 4.84(\mathrm{q}, J=6.4 \mathrm{~Hz}, 1 \mathrm{H}), 3.78(\mathrm{~s}, 3 \mathrm{H}), 1.88(\mathrm{~s}, 1 \mathrm{H}), 1.47(\mathrm{~d}, J=6.4 \mathrm{~Hz}, 3 \mathrm{H}) \mathrm{ppm} .{ }^{13} \mathrm{C}$ NMR $\left(126 \mathrm{MHz}, \mathrm{CDCl}_{3}\right) \delta=158.95,138.07,126.61,113.81,69.88,55.24,25.02 \mathrm{ppm}$.<smiles>OC(c1ccccc1)c1ccccc1</smiles>

(20) ${ }^{1} \mathrm{H}$ NMR $\left(500 \mathrm{MHz}, \mathrm{CDCl}_{3}\right) \delta=7.41(\mathrm{~d}, J=7.1 \mathrm{~Hz}, 4 \mathrm{H}), 7.36(\mathrm{t}, J=7.6$ $\mathrm{Hz}, 4 \mathrm{H}), 7.29(\mathrm{t}, J=7.7 \mathrm{~Hz}, 2 \mathrm{H}), 5.86(\mathrm{~s}, 1 \mathrm{H}), 2.22(\mathrm{~s}, 1 \mathrm{H}) \mathrm{ppm} .{ }^{13} \mathrm{C}$ NMR $(126 \mathrm{MHz}$, $\left.\mathrm{CDCl}_{3}\right) \delta=143.81,128.47,127.54,126.53,76.25 \mathrm{ppm}$.<smiles>CCOC(=O)C=Cc1ccc(C(C)=O)cc1</smiles>

${ }^{1} \mathrm{H}$ NMR $\left(500 \mathrm{MHz}, \mathrm{CDCl}_{3}\right) \delta=7.94(\mathrm{~d}, J=8.2 \mathrm{~Hz}, 2 \mathrm{H}), 7.67(\mathrm{~d}, J=$ $16.0 \mathrm{~Hz}, 1 \mathrm{H}), 7.58(\mathrm{~d}, J=8.1 \mathrm{~Hz}, 2 \mathrm{H}), 6.50(\mathrm{~d}, J=16.0 \mathrm{~Hz}, 1 \mathrm{H}), 4.26(\mathrm{q}, J=7.1 \mathrm{~Hz}, 2 \mathrm{H})$, $2.59(\mathrm{~s}, 3 \mathrm{H}), 1.33(\mathrm{t}, J=7.1 \mathrm{~Hz}, 3 \mathrm{H}) \mathrm{ppm} .{ }^{13} \mathrm{C} \mathrm{NMR}\left(126 \mathrm{MHz}, \mathrm{CDCl}_{3}\right) \delta=196.65,165.87$, $142.41,138.26,137.46,128.28,127.54,120.31,60.18,26.08,13.73$ ppm.<smiles>CCOC(=O)C=Cc1ccc(C#N)cc1</smiles>

${ }^{1} \mathrm{H}$ NMR $\left(500 \mathrm{MHz}, \mathrm{CDCl}_{3}\right) \delta=7.70-7.55(\mathrm{~m}, 5 \mathrm{H}), 6.50(\mathrm{~d}, J=16.0$ $\mathrm{Hz}, 1 \mathrm{H}), 4.27$ (q, $J=7.1 \mathrm{~Hz}, 2 \mathrm{H}), 1.33$ (t, $J=7.1 \mathrm{~Hz}, 3 \mathrm{H}) \mathrm{ppm} .{ }^{13} \mathrm{C}$ NMR $\left(126 \mathrm{MHz}, \mathrm{CDCl}_{3}\right)$ $\delta=166.05,142.05,138.74,132.59,128.32,121.89,118.28,113.34,60.87,14.22$ ppm 
EtOOC

${ }^{1} \mathrm{H}$ NMR $\left(500 \mathrm{MHz}, \mathrm{CDCl}_{3}\right) \delta=8.24(\mathrm{~d}, J=8.7 \mathrm{~Hz}, 2 \mathrm{H}), 7.68(\mathrm{dd}, J=$ 19.0, $12.4 \mathrm{~Hz}, 3 \mathrm{H}), 6.55(\mathrm{~d}, J=16.1 \mathrm{~Hz}, 1 \mathrm{H}), 4.29$ (q, $J=7.1 \mathrm{~Hz}, 2 \mathrm{H}), 1.35(\mathrm{t}, J=7.1 \mathrm{~Hz}$, $3 \mathrm{H}) \mathrm{ppm} .{ }^{13} \mathrm{C} \mathrm{NMR}\left(126 \mathrm{MHz}, \mathrm{CDCl}_{3}\right) \delta=165.95,141.55,140.58,128.56,124.13,122.61$, $60.95,14.22 \mathrm{ppm}$.<smiles>CCOC(=O)C=Cc1ccc(OC)cc1</smiles>

${ }^{1} \mathrm{H}$ NMR $\left(500 \mathrm{MHz}, \mathrm{CDCl}_{3}\right) \delta=7.63(\mathrm{~d}, J=15.9 \mathrm{~Hz}, 1 \mathrm{H}), 7.46(\mathrm{~d}, J=$ $8.6 \mathrm{~Hz}, 2 \mathrm{H}), 6.89(\mathrm{~d}, J=8.6 \mathrm{~Hz}, 2 \mathrm{H}), 6.30(\mathrm{~d}, J=15.9 \mathrm{~Hz}, 1 \mathrm{H}), 4.24(\mathrm{q}, J=7.1 \mathrm{~Hz}, 2 \mathrm{H}), 3.82$ (s, 3H), 1.32 (t, $J=7.1 \mathrm{~Hz}, 3 \mathrm{H}) \mathrm{ppm} .{ }^{13} \mathrm{C} \mathrm{NMR}\left(126 \mathrm{MHz}, \mathrm{CDCl}_{3}\right) \delta=167.25,161.32$, $144.17,129.63,127.21,115.78,114.29,60.25,55.31,14.32 \mathrm{ppm}$.

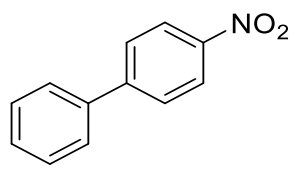

${ }^{1} \mathrm{H}$ NMR $\left(500 \mathrm{MHz}, \mathrm{CDCl}_{3}\right) \delta=8.30(\mathrm{~d}, J=8.6 \mathrm{~Hz}, 2 \mathrm{H}), 7.74(\mathrm{~d}, J=8.7$ $\mathrm{Hz}, 2 \mathrm{H}), 7.63(\mathrm{~d}, J=7.5 \mathrm{~Hz}, 2 \mathrm{H}), 7.50(\mathrm{t}, J=7.4 \mathrm{~Hz}, 2 \mathrm{H}), 7.45(\mathrm{t}, J=7.3 \mathrm{~Hz}, 1 \mathrm{H}) \mathrm{ppm} .{ }^{13} \mathrm{C}$ NMR $\left(126 \mathrm{MHz}, \mathrm{CDCl}_{3}\right) \delta=147.60,138.76,129.12,128.88,127.76,127.35,124.06$ ppm.<smiles>O=[N+]([O-])c1ccccc1-c1ccccc1</smiles>
$1.1 \mathrm{~Hz}, 1 \mathrm{H}), 7.52-7.40(\mathrm{~m}, 5 \mathrm{H}), 7.33(\mathrm{dd}, J=7.7,1.7 \mathrm{~Hz}, 2 \mathrm{H}) \mathrm{ppm} .{ }^{13} \mathrm{C} \mathrm{NMR}(126 \mathrm{MHz}$, $\left.\mathrm{CDCl}_{3}\right) \delta=137.38,136.33,132.20,131.93,128.64,128.20,128.12,127.88,124.02 \mathrm{ppm}$.<smiles>O=[N+]([O-])c1cccc(-c2ccccc2)c1</smiles>

${ }^{1} \mathrm{H}$ NMR $\left(500 \mathrm{MHz}, \mathrm{CDCl}_{3}\right) \delta=8.48-8.42(\mathrm{~s}, 1 \mathrm{H}), 8.19(\mathrm{dd}, J=8.2,1.2$ $\mathrm{Hz}, 1 \mathrm{H}), 7.91(\mathrm{dd}, J=7.8,0.4 \mathrm{~Hz}, 1 \mathrm{H}), 7.61(\mathrm{~m}, 3 \mathrm{H}), 7.50(\mathrm{t}, J=7.5 \mathrm{~Hz}, 2 \mathrm{H}), 7.43$ (t, $J=7.4$ $\mathrm{Hz}, 1 \mathrm{H}) \mathrm{ppm} .{ }^{13} \mathrm{C} \mathrm{NMR}\left(126 \mathrm{MHz}, \mathrm{CDCl}_{3}\right) \delta=142.85,138.63,137.56,132.98,129.67$, $129.14,128.52,127.12,121.98,121.89 \mathrm{ppm}$.

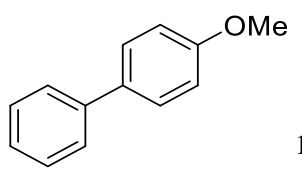

${ }^{1} \mathrm{H}$ NMR $\left(500 \mathrm{MHz}, \mathrm{CDCl}_{3}\right) \delta=7.59(\mathrm{dd}, J=11.3,8.2 \mathrm{~Hz}, 4 \mathrm{H}), 7.46(\mathrm{t}, J=$ $7.6 \mathrm{~Hz}, 2 \mathrm{H}), 7.34(\mathrm{t}, J=7.3 \mathrm{~Hz}, 1 \mathrm{H}), 7.02(\mathrm{~d}, J=8.6 \mathrm{~Hz}, 2 \mathrm{H}), 3.89$ (s, 3H) ppm. ${ }^{13} \mathrm{C} \mathrm{NMR}$ $\left(126 \mathrm{MHz}, \mathrm{CDCl}_{3}\right) \delta=159.19,140.86,133.81,128.72,128.15,126.74,126.66,114.24,55.35$ ppm. 
${ }^{1} \mathrm{H}$ NMR $\left(500 \mathrm{MHz}, \mathrm{CDCl}_{3}\right) \delta=7.56(\mathrm{~d}, J=7.1 \mathrm{~Hz}, 2 \mathrm{H}), 7.49-7.36(\mathrm{~m}$, 4H), $7.28(\mathrm{~m}, 1 \mathrm{H}), 6.77(\mathrm{~d}, J=8.2 \mathrm{~Hz}, 2 \mathrm{H}), 3.71(\mathrm{~s}, 2 \mathrm{H}) \mathrm{ppm} .{ }^{13} \mathrm{C} \mathrm{NMR}\left(126 \mathrm{MHz}, \mathrm{CDCl}_{3}\right) \delta$ $=145.84,141.17,131.58,128.64,127.99,126.39,126.23,115.37 \mathrm{ppm}$.

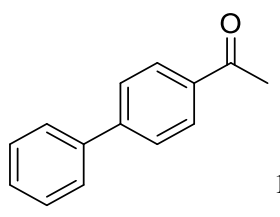

${ }^{1} \mathrm{H}$ NMR $\left(500 \mathrm{MHz}, \mathrm{CDCl}_{3}\right) \delta=8.06(\mathrm{~d}, J=8.1 \mathrm{~Hz}, 2 \mathrm{H}), 7.71(\mathrm{~d}, J=8.1 \mathrm{~Hz}$, 2H), $7.65(\mathrm{~d}, J=7.7 \mathrm{~Hz}, 2 \mathrm{H}), 7.50(\mathrm{t}, J=7.5 \mathrm{~Hz}, 2 \mathrm{H}), 7.43(\mathrm{t}, J=7.3 \mathrm{~Hz}, 1 \mathrm{H}), 2.66(\mathrm{~s}, 3 \mathrm{H})$ ppm. ${ }^{13} \mathrm{C}$ NMR $\left(126 \mathrm{MHz}, \mathrm{CDCl}_{3}\right) \delta=197.65,145.76,139.88,135.90,128.95,128.90$, 128.23, 127.26, 127.21, 26.62 ppm.

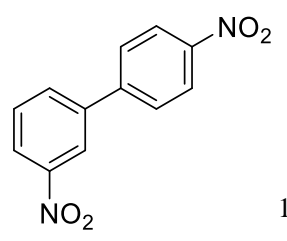

${ }^{1} \mathrm{H}$ NMR $\left(500 \mathrm{MHz}, \mathrm{CDCl}_{3}\right) \delta=8.49(\mathrm{~s}, 1 \mathrm{H}), 8.37(\mathrm{~d}, J=8.7 \mathrm{~Hz}, 2 \mathrm{H}), 8.31$ $(\mathrm{d}, J=8.2 \mathrm{~Hz}, 1 \mathrm{H}), 7.96(\mathrm{~d}, J=7.7 \mathrm{~Hz}, 1 \mathrm{H}), 7.80(\mathrm{~d}, J=8.7 \mathrm{~Hz}, 2 \mathrm{H}), 7.70(\mathrm{t}, J=8.0 \mathrm{~Hz}, 1 \mathrm{H})$ ppm. ${ }^{13} \mathrm{C}$ NMR $\left(126 \mathrm{MHz}, \mathrm{CDCl}_{3}\right) \delta=144.84,140.43,133.16,130.23,128.07,124.41$, $123.51,122.26,121.84,115.75 \mathrm{ppm}$.<smiles>O=[N+]([O-])c1ccc(-c2cc(C(F)(F)F)cc(C(F)(F)F)c2)cc1</smiles>

${ }^{1} \mathrm{H}$ NMR $\left(500 \mathrm{MHz}, \mathrm{CDCl}_{3}\right) \delta=8.37(\mathrm{~d}, J=8.6 \mathrm{~Hz}, 2 \mathrm{H}), 8.07(\mathrm{~s}, 2 \mathrm{H})$, $7.96(\mathrm{~s}, 1 \mathrm{H}), 7.81(\mathrm{~d}, J=8.6 \mathrm{~Hz}, 2 \mathrm{H}) \mathrm{ppm} .{ }^{13} \mathrm{C} \mathrm{NMR}\left(126 \mathrm{MHz}, \mathrm{CDCl}_{3}\right) \delta=148.13,144.27$, 140.96, $132.65(\mathrm{q}, J=33.6 \mathrm{~Hz}), 128.21,127.48(\mathrm{~d}, J=2.9 \mathrm{~Hz}), 124.44,123.07$ (q, $J=272.8$ $\mathrm{Hz}), 122.40(\mathrm{~h}, J=3.6 \mathrm{~Hz}) \mathrm{ppm}$.

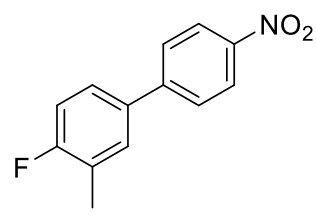

${ }^{1} \mathrm{H}$ NMR $\left(500 \mathrm{MHz}, \mathrm{CDCl}_{3}\right) \delta=8.26(\mathrm{~d}, J=8.7 \mathrm{~Hz}, 2 \mathrm{H}), 7.67(\mathrm{~d}, J=8.7$ $\mathrm{Hz}, 2 \mathrm{H}), 7.44(\mathrm{~d}, J=7.2 \mathrm{~Hz}, 1 \mathrm{H}), 7.40(\mathrm{~m}, 1 \mathrm{H}), 7.11$ (t, $J=8.9 \mathrm{~Hz}, 1 \mathrm{H}), 2.36$ (s, 3H) ppm. ${ }^{13} \mathrm{C} \mathrm{NMR}\left(126 \mathrm{MHz}, \mathrm{CDCl}_{3}\right) \delta=161.93(\mathrm{~d}, J=248.1 \mathrm{~Hz}), 146.95,146.76,134.58(\mathrm{~d}, J=3.6$ $\mathrm{Hz}), 130.53(\mathrm{~d}, J=5.6 \mathrm{~Hz}), 127.53,126.36$ (d, $J=8.3 \mathrm{~Hz}), 125.74(\mathrm{~d}, J=17.7 \mathrm{~Hz}), 124.04$, $115.73(\mathrm{~d}, J=22.9 \mathrm{~Hz}), 14.62(\mathrm{~d}, J=3.6 \mathrm{~Hz}) \mathrm{ppm}$. 
<smiles>FC(F)(F)c1cc(-c2cccnc2)cc(C(F)(F)F)c1</smiles>

${ }^{1} \mathrm{H}$ NMR $\left(500 \mathrm{MHz}, \mathrm{CDCl}_{3}\right) \delta=8.88(\mathrm{~s}, 1 \mathrm{H}), 8.71(\mathrm{~d}, J=3.5 \mathrm{~Hz}, 1 \mathrm{H}), 8.01$ $(\mathrm{s}, 2 \mathrm{H}), 7.93(\mathrm{~d}, J=9.5 \mathrm{~Hz}, 2 \mathrm{H}), 7.51-7.42(\mathrm{~m}, 1 \mathrm{H}) \mathrm{ppm} .{ }^{13} \mathrm{C} \mathrm{NMR}\left(126 \mathrm{MHz}, \mathrm{CDCl}_{3}\right) \delta=$ 149.78, 147.95, 139.94, 134.74, 134.03, 132.59 (q, $J=33.4 \mathrm{~Hz}), 127.24$ (d, $J=2.8 \mathrm{~Hz})$, 123.92, 123.12 (q, J=273.7 Hz), 121.84 (h, $J=3.8 \mathrm{~Hz}) \mathrm{ppm}$.

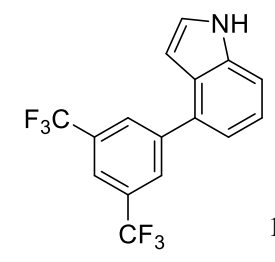

${ }^{1} \mathrm{H}$ NMR $\left(500 \mathrm{MHz}, \mathrm{CDCl}_{3}\right) \delta=8.36(\mathrm{~s}, 1 \mathrm{H}), 8.17(\mathrm{~s}, 2 \mathrm{H}), 7.89(\mathrm{~s}, 1 \mathrm{H}), 7.49$ $(\mathrm{d}, J=8.1 \mathrm{~Hz}, 1 \mathrm{H}), 7.35-7.31(\mathrm{~m}, 2 \mathrm{H}), 7.23(\mathrm{~d}, J=7.3 \mathrm{~Hz}, 1 \mathrm{H}), 6.65(\mathrm{~s}, 1 \mathrm{H}) \mathrm{ppm} .{ }^{13} \mathrm{C} \mathrm{NMR}$ $\left(126 \mathrm{MHz}, \mathrm{CDCl}_{3}\right) \delta=143.35,136.32,131.80(\mathrm{q}, J=33.1 \mathrm{~Hz}), 131.14,128.88-128.46(\mathrm{~m})$, 125.84, 125.40, 124.60, 122.45, $120.50(\mathrm{~h}, J=3.9 \mathrm{~Hz}), 120.11,111.71,101.17$ ppm. A $\mathrm{CF}_{3}$ szén-13 kvartett jele 240 ppm körül a kis intenzitás miatt nem látható.

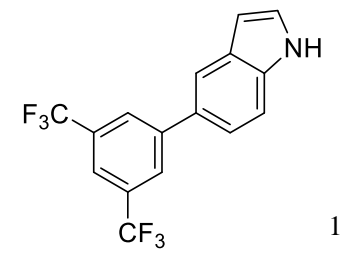

${ }^{1} \mathrm{H}$ NMR $\left(500 \mathrm{MHz}, \mathrm{CDCl}_{3}\right) \delta=8.27(\mathrm{~s}, 1 \mathrm{H}), 8.07$ (s, 2H), $7.90(\mathrm{~s}, 1 \mathrm{H})$, $7.81(\mathrm{~s}, 1 \mathrm{H}), 7.52(\mathrm{~d}, J=8.4 \mathrm{~Hz}, 1 \mathrm{H}), 7.45(\mathrm{dd}, J=8.5,1.4 \mathrm{~Hz}, 1 \mathrm{H}), 7.30$ (t, $J=2.6 \mathrm{~Hz}, 1 \mathrm{H})$, $6.66(\mathrm{~s}, 1 \mathrm{H}) \mathrm{ppm} .{ }^{13} \mathrm{C} \mathrm{NMR}\left(126 \mathrm{MHz}, \mathrm{CDCl}_{3}\right) \delta=144.59$ (s), 135.96 (s), 131.86 (q, $J=$ 33.0), 130.32 (s), 128.58 (s), 127.21 (m), 125.44 (s), 123.54 (q, $J=272.7$ Hz), 121.43 (s), $119.80(\mathrm{~m}), 119.69$ (s), 111.75 (s), 103.30 (s) ppm.

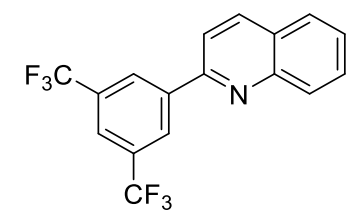

${ }^{1} \mathrm{H}$ NMR $\left(500 \mathrm{MHz}, \mathrm{CDCl}_{3}\right) \delta=8.66(\mathrm{~s}, 2 \mathrm{H}), 8.29(\mathrm{~d}, J=8.5 \mathrm{~Hz}, 1 \mathrm{H})$, $8.21(\mathrm{~d}, J=8.5 \mathrm{~Hz}, 1 \mathrm{H}), 7.97(\mathrm{~s}, 1 \mathrm{H}), 7.88(\mathrm{dd}, J=21.4,8.3 \mathrm{~Hz}, 2 \mathrm{H}), 7.78(\mathrm{t}, J=7.4 \mathrm{~Hz}, 1 \mathrm{H})$, 7.59 (t, $J=7.5 \mathrm{~Hz}, 1 \mathrm{H}) \mathrm{ppm} .{ }^{13} \mathrm{C} \mathrm{NMR}\left(126 \mathrm{MHz}, \mathrm{CDCl}_{3}\right) \delta=153.54,148.09,141.37$, $137.54,132.16(\mathrm{q}, J=33.4 \mathrm{~Hz}), 130.29,129.81,127.58,127.50,127.46,127.27,124.48$ (q, $J$ $=272.6 \mathrm{~Hz}), 122.71(\mathrm{~h}, J=3.7 \mathrm{~Hz}), 118.04 \mathrm{ppm}$.

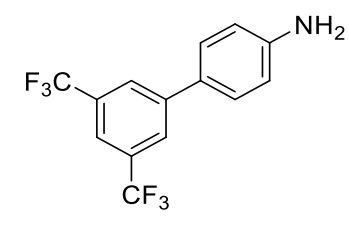

${ }^{1} \mathrm{H}$ NMR $\left(500 \mathrm{MHz}, \mathrm{CDCl}_{3}\right) \delta=7.96(\mathrm{~s}, 2 \mathrm{H}), 7.79(\mathrm{~s}, 1 \mathrm{H}), 7.44(\mathrm{~d}, J=$ $8.4 \mathrm{~Hz}, 2 \mathrm{H}), 6.78(\mathrm{~d}, J=8.4 \mathrm{~Hz}, 2 \mathrm{H}), 3.82(\mathrm{~s}, 2 \mathrm{H}) \mathrm{ppm} .{ }^{13} \mathrm{C} \mathrm{NMR}\left(126 \mathrm{MHz}, \mathrm{CDCl}_{3}\right) \delta=$ 
147.31, 143.17, 131.89 (q, $J=33.0 \mathrm{~Hz}), 128.13,128.07,126.09,123.55$ (q, $J=272.7 \mathrm{~Hz}$ ), $119.58(\mathrm{~h}, J=3.9 \mathrm{~Hz}), 115.43 \mathrm{ppm}$.

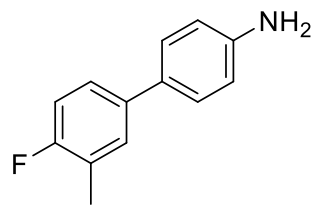

${ }^{1} \mathrm{H}$ NMR $\left(500 \mathrm{MHz}, \mathrm{CDCl}_{3}\right) \delta=7.41-7.22(\mathrm{~m}, 4 \mathrm{H}), 7.02(\mathrm{t}, J=8.9 \mathrm{~Hz}$, $1 \mathrm{H}), 6.74(\mathrm{~d}, J=8.2 \mathrm{~Hz}, 2 \mathrm{H}), 3.70(\mathrm{~s}, 2 \mathrm{H}), 2.33(\mathrm{~s}, 3 \mathrm{H}) \mathrm{ppm} .{ }^{13} \mathrm{C} \mathrm{NMR}\left(126 \mathrm{MHz}, \mathrm{CDCl}_{3}\right) \delta$ $=161.41,145.67,137.04,130.87,129.44,129.40,127.83,125.14,125.08,115.35,115.12$, $114.95,14.67 \mathrm{ppm}$.

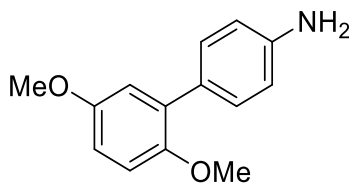

${ }^{1} \mathrm{H}$ NMR $\left(500 \mathrm{MHz}, \mathrm{CDCl}_{3}\right) \delta=7.38(\mathrm{~d}, J=8.3 \mathrm{~Hz}, 2 \mathrm{H}), 6.94-6.88$ (m, 2H), $6.82(\mathrm{dd}, J=8.9,3.0 \mathrm{~Hz}, 1 \mathrm{H}), 6.74(\mathrm{~d}, J=8.4 \mathrm{~Hz}, 2 \mathrm{H}), 3.82(\mathrm{~s}, 3 \mathrm{H}), 3.76(\mathrm{~s}, 3 \mathrm{H})$, $3.53(\mathrm{~s}, 2 \mathrm{H}) \mathrm{ppm} .{ }^{13} \mathrm{C} \mathrm{NMR}\left(126 \mathrm{MHz}, \mathrm{CDCl}_{3}\right) \delta=153.83,150.88,145.56,131.86,130.36$, $128.56,116.41,114.77,112.82,112.27,56.38,55.77 \mathrm{ppm}$.

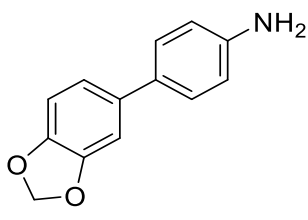

${ }^{1} \mathrm{H}$ NMR $\left(500 \mathrm{MHz}, \mathrm{CDCl}_{3}\right) \delta=7.34(\mathrm{~d}, J=8.4 \mathrm{~Hz}, 2 \mathrm{H}), 7.06-6.97(\mathrm{~m}$, $2 \mathrm{H}), 6.86(\mathrm{~d}, J=8.0 \mathrm{~Hz}, 1 \mathrm{H}), 6.73(\mathrm{~d}, J=8.4 \mathrm{~Hz}, 2 \mathrm{H}), 5.98(\mathrm{~s}, 2 \mathrm{H}), 3.70(\mathrm{~s}, 2 \mathrm{H}) \mathrm{ppm} .{ }^{13} \mathrm{C}$ NMR $\left(126 \mathrm{MHz}, \mathrm{CDCl}_{3}\right) \delta=148.00,146.26,145.56,135.74,131.40,127.74,119.66,115.36$, $108.47,107.12,100.96 \mathrm{ppm}$.

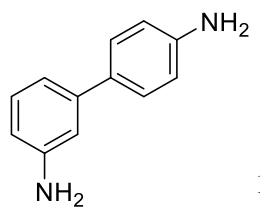

${ }^{1} \mathrm{H}$ NMR $\left(500 \mathrm{MHz}, \mathrm{CDCl}_{3}\right) \delta=7.40(\mathrm{~d}, J=8.2 \mathrm{~Hz}, 2 \mathrm{H}), 7.19(\mathrm{t}, J=7.7 \mathrm{~Hz}$, 1H), $6.96(\mathrm{~d}, J=7.2 \mathrm{~Hz}, 1 \mathrm{H}), 6.86(\mathrm{~s}, 1 \mathrm{H}), 6.73(\mathrm{~d}, J=8.3 \mathrm{~Hz}, 2 \mathrm{H}), 6.66-6.57(\mathrm{~m}, 1 \mathrm{H}), 3.69$ (s, 4H) ppm. ${ }^{13} \mathrm{C}$ NMR $\left(126 \mathrm{MHz}, \mathrm{CDCl}_{3}\right) \delta=146.67,145.81,142.36,131.72,129.55$, $127.93,127.27,117.00,115.29,113.23$ ppm.<smiles>Nc1cccc(-c2ccccc2)c1</smiles>

${ }^{1} \mathrm{H}$ NMR $\left(500 \mathrm{MHz}, \mathrm{CDCl}_{3}\right) \delta=7.62(\mathrm{~d}, J=7.2 \mathrm{~Hz}, 2 \mathrm{H}), 7.47(\mathrm{t}, J=7.5 \mathrm{~Hz}$, 2H), $7.38(\mathrm{t}, J=7.4 \mathrm{~Hz}, 1 \mathrm{H}), 7.27(\mathrm{t}, J=7.8 \mathrm{~Hz}, 1 \mathrm{H}), 7.05(\mathrm{dd}, J=7.6,0.5 \mathrm{~Hz}, 1 \mathrm{H}), 6.94(\mathrm{t}, J$ $=1.6 \mathrm{~Hz}, 1 \mathrm{H}), 6.73-6.67(\mathrm{~m}, 1 \mathrm{H}), 3.71(\mathrm{~s}, 2 \mathrm{H}) \mathrm{ppm} .{ }^{13} \mathrm{C} \mathrm{NMR}\left(126 \mathrm{MHz}, \mathrm{CDCl}_{3}\right) \delta=$ $146.74,142.48,141.44,129.71,128.67,127.25,127.14,117.71,114.17,113.96$ ppm. 


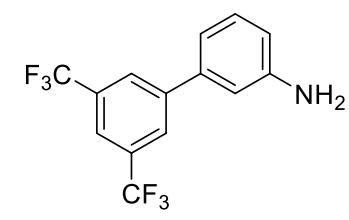

${ }^{1} \mathrm{H} \mathrm{NMR}\left(500 \mathrm{MHz}, \mathrm{CDCl}_{3}\right) \delta=7.99(\mathrm{~s}, 2 \mathrm{H}), 7.84(\mathrm{~s}, 1 \mathrm{H}), 7.28(\mathrm{t}, J=7.8$ $\mathrm{Hz}, 1 \mathrm{H}), 6.98(\mathrm{~d}, J=7.5 \mathrm{~Hz}, 1 \mathrm{H}), 6.89(\mathrm{~s}, 1 \mathrm{H}), 6.76(\mathrm{~d}, J=6.7 \mathrm{~Hz}, 1 \mathrm{H}), 3.78(\mathrm{~s}, 2 \mathrm{H}) \mathrm{ppm} .{ }^{13} \mathrm{C}$ $\operatorname{NMR}\left(126 \mathrm{MHz}, \mathrm{CDCl}_{3}\right) \delta=147.16,143.51,139.39,131.96$ (q, $\left.J=33.2 \mathrm{~Hz}\right), 130.20,127.13$, 123.37 (q, $J=272.7 \mathrm{~Hz}), 120.77$ (h, $J=3.9 \mathrm{~Hz}), 117.44,115.42,113.52$ ppm.

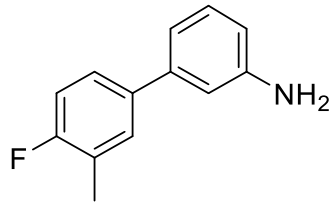

${ }^{1} \mathrm{H}$ NMR $\left(500 \mathrm{MHz}, \mathrm{CDCl}_{3}\right) \delta=7.35(\mathrm{~m}, 2 \mathrm{H}), 7.22(\mathrm{t}, J=7.7 \mathrm{~Hz}, 1 \mathrm{H})$, $7.05(\mathrm{t}, J=8.9 \mathrm{~Hz}, 1 \mathrm{H}), 6.94(\mathrm{~d}, J=7.6 \mathrm{~Hz}, 1 \mathrm{H}), 6.86(\mathrm{~s}, 1 \mathrm{H}), 6.67(\mathrm{~d}, J=6.6 \mathrm{~Hz}, 1 \mathrm{H}), 3.73$ (s, 2H), 2.34 (s, 3H) ppm. ${ }^{13} \mathrm{C}$ NMR (126 MHz, $\left.\mathrm{CDCl}_{3}\right) \delta=161.96,160.01,146.62,141.67$, $137.21,137.19,130.17,130.13,129.66,125.89,125.82,124.89,124.75,117.55,115.16$, 114.98, 113.98, 113.77, 14.66, $14.63 \mathrm{ppm}$.<smiles>COc1ccc(OC)c(-c2cccc(N)c2)c1</smiles>

${ }^{1} \mathrm{H}$ NMR $\left(500 \mathrm{MHz}, \mathrm{CDCl}_{3}\right) \delta=7.21(\mathrm{t}, J=7.8 \mathrm{~Hz}, 1 \mathrm{H}), 6.95(\mathrm{~d}, J=$ $7.6 \mathrm{~Hz}, 1 \mathrm{H}), 6.92-6.88(\mathrm{~m}, 3 \mathrm{H}), 6.84(\mathrm{dd}, J=8.8,3.1 \mathrm{~Hz}, 1 \mathrm{H}), 6.70(\mathrm{~d}, J=7.9 \mathrm{~Hz}, 1 \mathrm{H}), 3.80$ (s, 3H), 3.74 (s, 3H), 3.56 (s, 2H) ppm. ${ }^{13} \mathrm{C}$ NMR $\left(126 \mathrm{MHz}, \mathrm{CDCl}_{3}\right) \delta=153.71,150.81$, $145.39,139.54,131.87,128.90,120.35,116.64,116.56,114.31,113.16,112.86,56.43,55.77$ ppm.

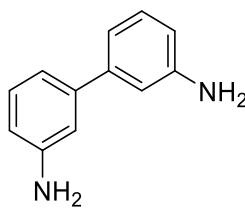

${ }^{1} \mathrm{H}$ NMR $(500 \mathrm{MHz}, \mathrm{DMSO}) \delta=7.04(\mathrm{t}, J=7.8 \mathrm{~Hz}, 2 \mathrm{H}), 6.76(\mathrm{t}, J=1.6 \mathrm{~Hz}$, $2 \mathrm{H}), 6.68(\mathrm{~d}, J=7.6 \mathrm{~Hz}, 2 \mathrm{H}), 6.52(\mathrm{dd}, J=7.8,1.8 \mathrm{~Hz}, 2 \mathrm{H}), 5.07$ (s, 4H) ppm. ${ }^{13} \mathrm{C}$ NMR $(126$ MHz, DMSO) $\delta=149.27,142.29,129.57,114.77,113.33,112.59$ ppm.

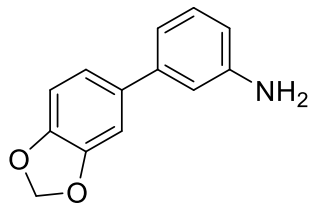

${ }^{1} \mathrm{H}$ NMR $\left(500 \mathrm{MHz}, \mathrm{CDCl}_{3}\right) \delta=7.20(\mathrm{t}, J=7.8 \mathrm{~Hz}, 1 \mathrm{H}), 7.06-7.03(\mathrm{~m}$, 2H), $6.93(\mathrm{~d}, J=7.7 \mathrm{~Hz}, 1 \mathrm{H}), 6.89-6.80(\mathrm{~m}, 2 \mathrm{H}), 6.68-6.60(\mathrm{~m}, 1 \mathrm{H}), 5.99(\mathrm{~s}, 2 \mathrm{H}), 3.70(\mathrm{~s}$, $2 \mathrm{H}) \mathrm{ppm} .{ }^{13} \mathrm{C}$ NMR $\left(126 \mathrm{MHz}, \mathrm{CDCl}_{3}\right) \delta=147.96,146.98,146.69,142.12,135.79,129.64$, $120.51,117.42,113.81,113.65,108.43,107.65,101.06 \mathrm{ppm}$. 


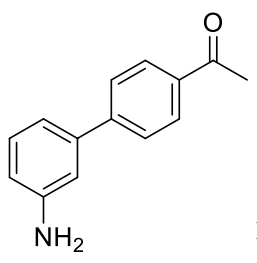

${ }^{1} \mathrm{H}$ NMR $\left(500 \mathrm{MHz}, \mathrm{CDCl}_{3}\right) \delta=8.00(\mathrm{~d}, J=8.2 \mathrm{~Hz}, 2 \mathrm{H}), 7.65(\mathrm{~d}, J=8.2 \mathrm{~Hz}$, 2H), $7.25(\mathrm{t}, J=7.7 \mathrm{~Hz}, 1 \mathrm{H}), 7.01(\mathrm{~d}, J=7.6 \mathrm{~Hz}, 1 \mathrm{H}), 6.93(\mathrm{~s}, 1 \mathrm{H}), 6.72(\mathrm{dd}, J=7.9,1.4 \mathrm{~Hz}$, 1H), 3.78 (s, 2H), 2.63 (s, 3H) ppm. $\left.{ }^{13} \mathrm{C} \mathrm{NMR} \mathrm{(126} \mathrm{MHz,} \mathrm{CDCl}_{3}\right) \delta=197.72,146.86,146.00$, $141.06,135.84,129.85,128.76,127.14,117.67,114.95,113.78,26.59$ ppm.

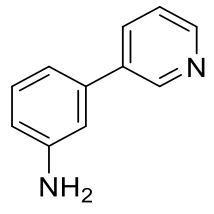

${ }^{1} \mathrm{H}$ NMR (500 MHz, DMSO) $\delta=8.76(\mathrm{~s}, 1 \mathrm{H}), 8.51(\mathrm{~d}, J=4.6 \mathrm{~Hz}, 1 \mathrm{H}), 7.91(\mathrm{~d}, J$ $=7.9 \mathrm{~Hz}, 1 \mathrm{H}), 7.41(\mathrm{dd}, J=7.8,4.8 \mathrm{~Hz}, 1 \mathrm{H}), 7.12(\mathrm{t}, J=7.8 \mathrm{~Hz}, 1 \mathrm{H}), 6.86(\mathrm{~s}, 1 \mathrm{H}), 6.80(\mathrm{~d}, J$ $=7.5 \mathrm{~Hz}, 1 \mathrm{H}), 6.65-6.58(\mathrm{~m}, 1 \mathrm{H}), 5.19(\mathrm{~s}, 2 \mathrm{H}) \mathrm{ppm} .{ }^{13} \mathrm{C} \mathrm{NMR}(126 \mathrm{MHz}, \mathrm{DMSO}) \delta=$ $149.74,148.58,147.85,138.19,136.86,134.23,130.09,124.18,114.84,114.23,112.53$ ppm.

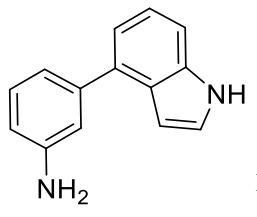

${ }^{1} \mathrm{H}$ NMR (500 MHz, DMSO) $\delta=11.15(\mathrm{~s}, 1 \mathrm{H}), 7.40-7.30(\mathrm{~m}, 2 \mathrm{H}), 7.12(\mathrm{q}, J$ $=8.0 \mathrm{~Hz}, 2 \mathrm{H}), 7.01(\mathrm{~d}, J=7.1 \mathrm{~Hz}, 1 \mathrm{H}), 6.91(\mathrm{~s}, 1 \mathrm{H}), 6.80(\mathrm{~d}, J=7.4 \mathrm{~Hz}, 1 \mathrm{H}), 6.56(\mathrm{~s}, 2 \mathrm{H})$, 5.09 (s, 2H) ppm. ${ }^{13} \mathrm{C}$ NMR (126 MHz, DMSO) $\delta=149.23,142.14,136.81,134.39,129.41$, 126.04, 125.77, 121.65, 118.53, 116.53, 114.41, 113.09, 110.83, 101.05 ppm.

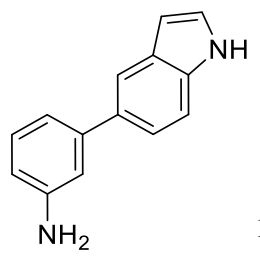

${ }^{1} \mathrm{H}$ NMR (500 MHz, DMSO) $\delta=11.06(\mathrm{~s}, 1 \mathrm{H}), 7.70(\mathrm{~s}, 1 \mathrm{H}), 7.42(\mathrm{~d}, J=8.4$ Hz, 1H), 7.33 (s, 1H), 7.30 (d, $J=8.4 \mathrm{~Hz}, 1 \mathrm{H}), 7.07$ (t, $J=7.7 \mathrm{~Hz}, 1 \mathrm{H}), 6.88(\mathrm{~s}, 1 \mathrm{H}), 6.80$ (d, $J=7.6 \mathrm{~Hz}, 1 \mathrm{H}), 6.52(\mathrm{dd}, J=7.9,0.7 \mathrm{~Hz}, 1 \mathrm{H}), 6.45(\mathrm{~s}, 1 \mathrm{H}), 5.18(\mathrm{~s}, 2 \mathrm{H}) \mathrm{ppm} .{ }^{13} \mathrm{C}$ NMR $(126$ MHz, DMSO) $\delta=153.74,147.85,140.56,137.41,134.37,133.32,131.01,125.50,122.96$, $120.05,117.84,117.45,116.72,106.62 \mathrm{ppm}$.

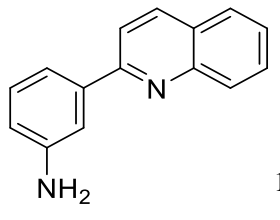

${ }^{1} \mathrm{H}$ NMR (500 MHz, DMSO) $\delta=8.37(\mathrm{~d}, J=8.6 \mathrm{~Hz}, 1 \mathrm{H}), 8.02(\mathrm{~d}, J=8.5 \mathrm{~Hz}$, 1H), $7.96(\mathrm{t}, J=10.0 \mathrm{~Hz}, 2 \mathrm{H}), 7.74(\mathrm{t}, J=7.3 \mathrm{~Hz}, 1 \mathrm{H}), 7.59-7.49(\mathrm{~m}, 2 \mathrm{H}), 7.34(\mathrm{~d}, J=7.5$ $\mathrm{Hz}, 1 \mathrm{H}), 7.17(\mathrm{t}, J=7.7 \mathrm{~Hz}, 1 \mathrm{H}), 6.70(\mathrm{~d}, J=7.9 \mathrm{~Hz}, 1 \mathrm{H}), 5.24(\mathrm{~s}, 2 \mathrm{H}) \mathrm{ppm} .{ }^{13} \mathrm{C}$ NMR $(126$ 
MHz, DMSO) $\delta=157.34,149.57,147.97,139.81,137.26,130.19,129.71,129.39,128.18$, $127.35,126.59,119.21,115.76,115.45,112.97 \mathrm{ppm}$.

\section{2. Ábrák}
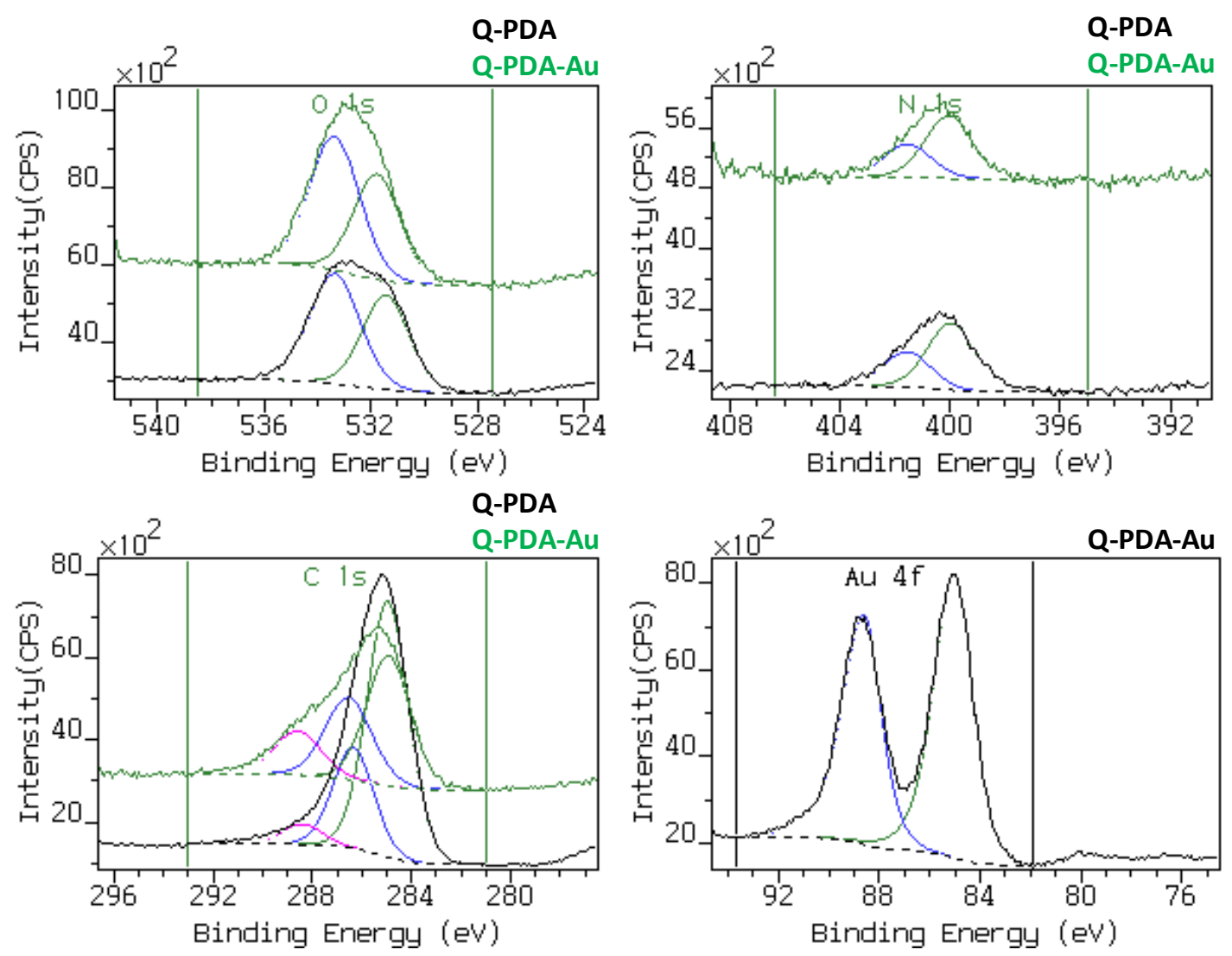

M1. ábra Q-PDA és Q-PDA-Au XPS spektrumainak részletei. $\mathrm{Az} A \mathrm{Au}$ 4f jelének eltolódásértéke apró szemcseátmérőjű $\mathrm{Au}(0)$ jelenlétére utal. 


\section{$\boldsymbol{a}$}
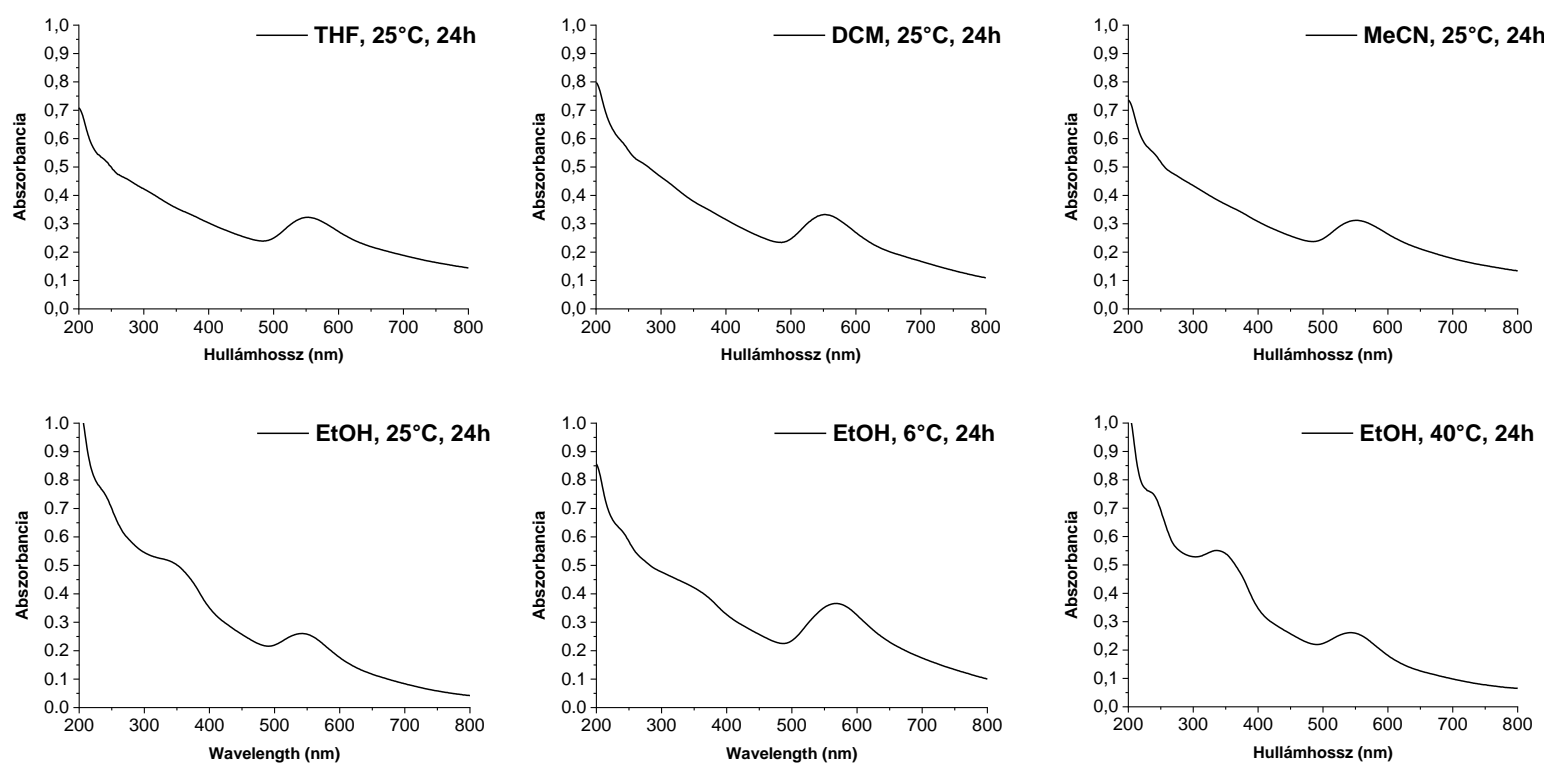

b
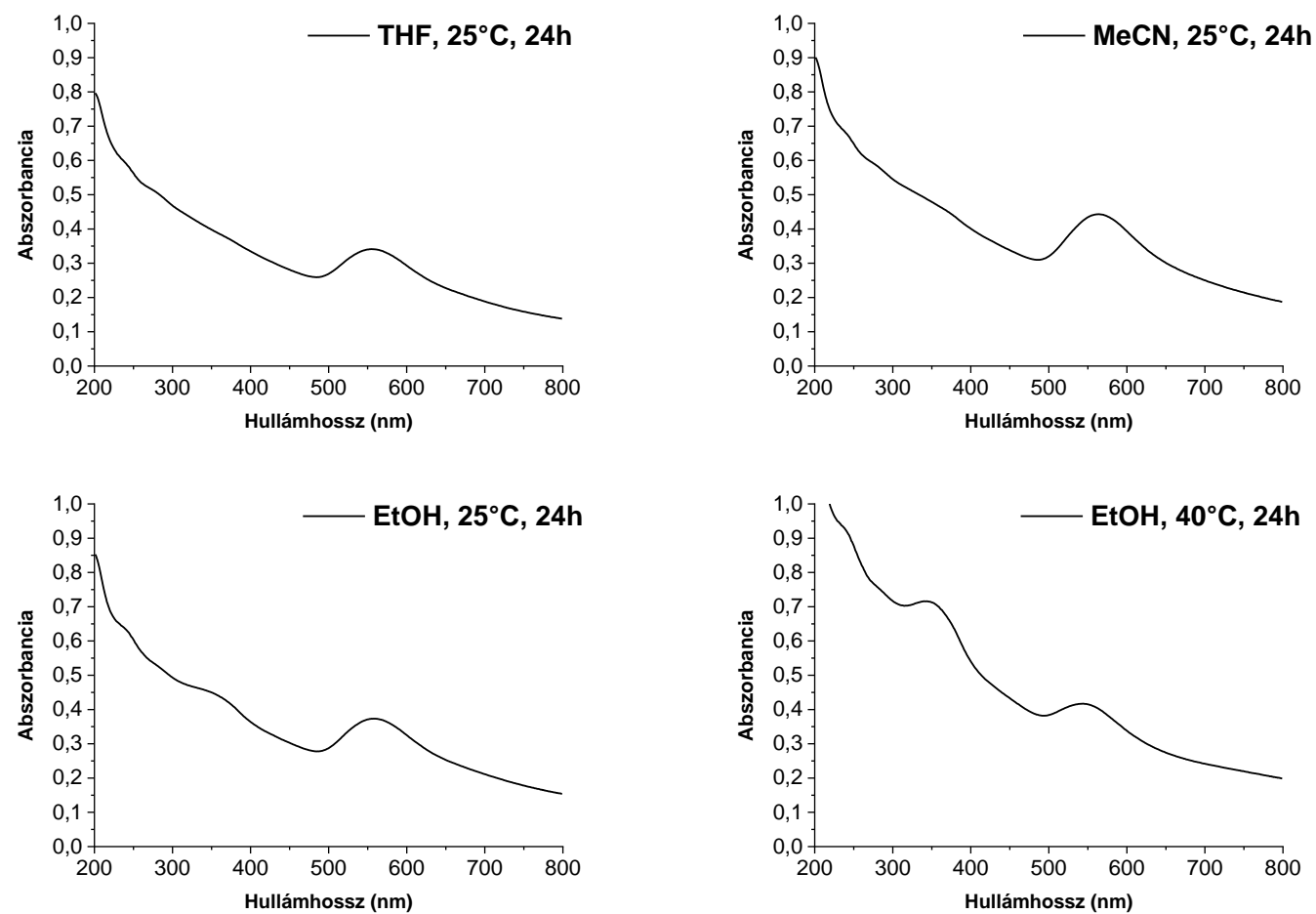

M2. ábra Q-PDA-Au felület (a) $\mathrm{AzoC}_{6} \mathrm{SH}$, és (b) $\mathrm{AzoC}_{6} \mathrm{NH}_{2}-$ nal való funkcionalizálhatóságának vizsgálata különböző körülmények között. 

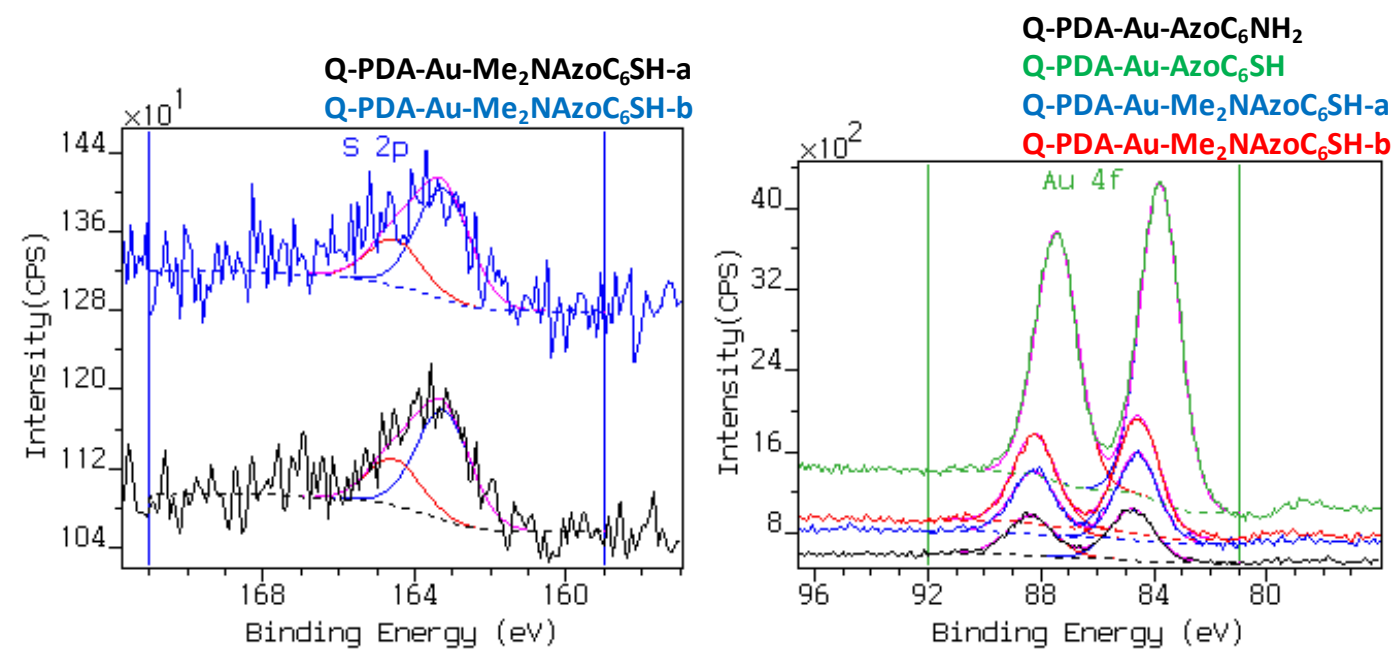

M3. ábra Q-PDA-Au-,,Azo” minták XPS spektrumainak részletei. Az S 2p jel eltolódása 1 eV-tal alacsonyabban helyezkedik el, mint a nem kötött ligandumok esetén, míg az Au 4f jele magasabban található a ligandummentes Q-PDA-Au-nál tapasztaltakhoz képest, ami Au-S interakcióra utal. 

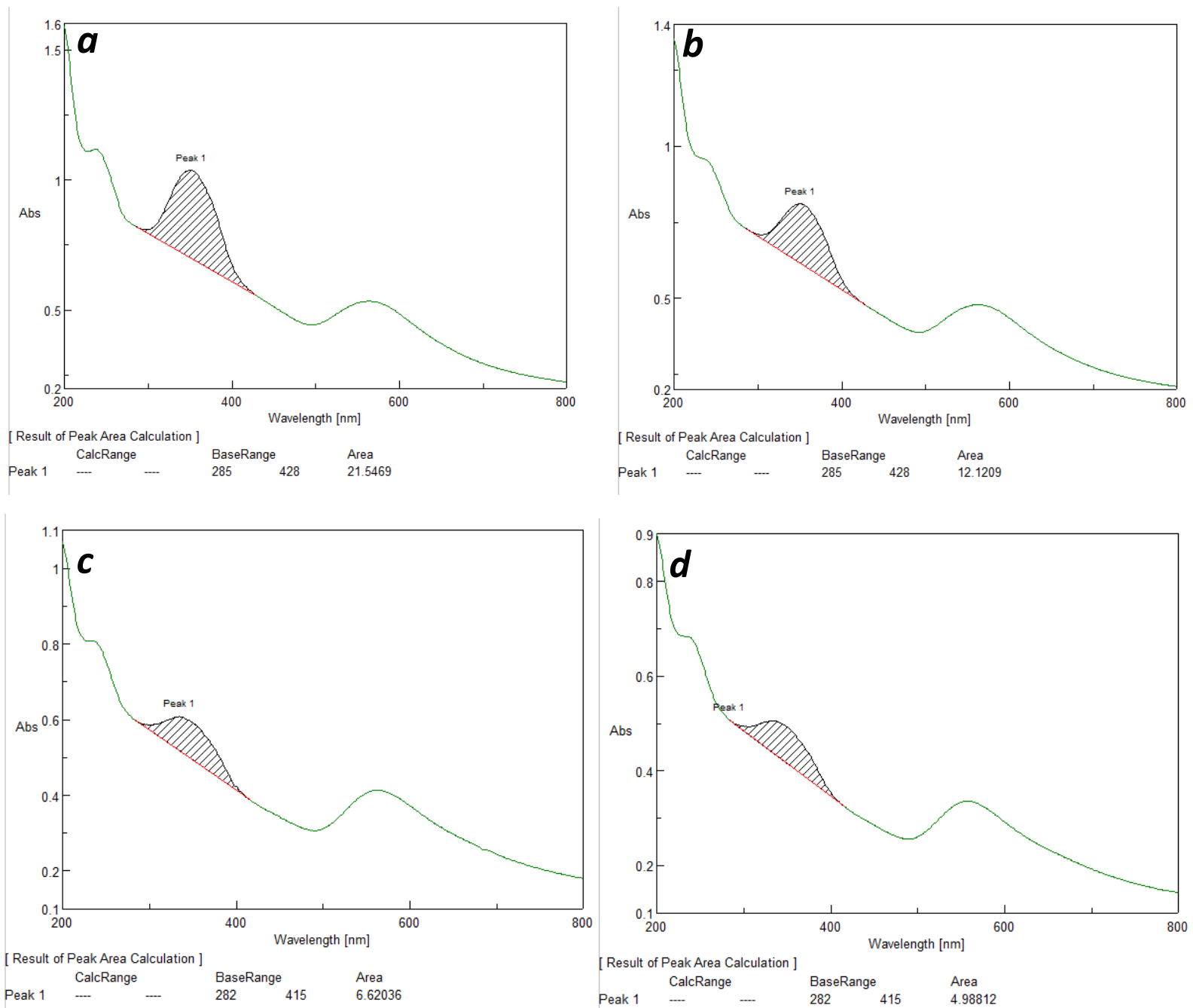

M4. ábra $(a, b)$ Q-PDA-Au-AzoC ${ }_{6} \mathrm{NH}_{2}$, és $(c, d)-\mathrm{AzoC}_{6} \mathrm{SH}$ deszorpciójának követése cserélő ligandum mentes EtOH-ban $\left(40^{\circ} \mathrm{C}, 24 \mathrm{~h}\right)$. $(a, c)$ Deszorpciós kísérlet előtt, és $(b, d)$ után. A spektrumok alapján az amin-terminális azobenzolok mennyisége $45 \%$-al, míg a tiolterminális azobenzoloké csak $25 \%$-al csökkent a felületen 24 óra alatt. 


\section{Köszönetnyilvánítás}

Elsősorban témavezetőmnek, London Gábornak szeretném megköszönni, hogy lehetővé tette számomra, és mindenben támogatta kutatómunkám végzését a Funkcionális Szerves Anyagok Kutatócsoportban. Köszönöm az eltelt évek alatt átadott szakmai tapasztalatot, tanácsot és támogatást, valamint a doktori disszertációm alapos áttanulmányozását és értékes észrevételeit.

Továbbá köszönettel tartozom Bucsi Imrének, és Mastalir Ágnesnek, akik a szegedi egyetemi éveim alatt szintén témavezetőimként megalapozták a szakmai előmenetelemhez szükséges utat. Köszönöm a számos elméleti és gyakorlati tanácsot, amit a közös munka során kaptam. Gabnai Jánosnak, valamint Szőri Kornélnak köszönöm a rengeteg technikai segítséget, valamint a vidám hangulatot, ami a sikeres hallgatói laboratóriumi oktatómunkámat biztosította, továbbá köszönöm, hogy a laborgyakorlatok után is nyitottak voltak hosszú, izgalmas szakmai beszélgetésekre.

Köszönet illeti Wölfling Jánost, az SZTE Szerves Kémiai Tanszékének vezetőjét, és a Kémiai Intézet minden dolgozóját, aki segítette tanulmányi, valamint szakmai előmenetelemet.

Hálával tartozom Soós Tibornak és Kele Péternek, valamint kutatócsoportjaiknak, hogy befogadtak minket az MTA TTK Szerves Kémiai Intézetébe, és mindenben segítették az elmúlt évek során megszülető kutatócsoportunkat.

Köszönöm a Funkcionális Szerves Anyagok Kutatócsoport minden volt és jelenlegi tagjának, különösképpen hallgatóimnak, hogy közös munkával, és jó hangulattal támogattuk egymást a mindennapi laboratóriumi munka során.

Köszönettel tartozom Ábrahám Ágnes, Kiss Éva, Bertóti Imre, May Zoltán, Miskolczy Zsombor, Mohai Miklós, és Németh Péter műszeres mérésekben, valamint az eredmények kiértékelésében nyújtott segítségét, nélkülük a kémia csak megalapozatlan hipotézisek halmaza lenne.

Nem utolsó sorban, pedig hálásan köszönöm Szüleimnek a megnyugtató családi légkört, melyet mindvégig biztosítottak. Támogatásuk, bizalmuk és társaságuk még a legnehezebb időszakokon is segített átlendülni. Nélkülük disszertációm nem készülhetett volna el. 